THE ROLE OF HETEROTROPHIC MICROFLAGELLATES

IN PLANKTON COMMUNITIES

by

DAVID A. CARON

B.S., University of Rhode Island, Kingston

(1975)

M.S., University of Rhode Island, Kingston (1977)

SUBMITTED IN PARTIAL FULFILLMENT

OF THE REQUIREMENTS FOR THE

DEGREE OF

DOCTOR OF PHILOSOPHY

IN THE

WOODS HOLE OCEANOGRAPHIC INSTITUTION-

MASSACHUSETTS INSTITUTE OF TECHNOLOGY

JOINT PROGRAM IN BIOLOGICAI OCEANOGRAPHY

June, 1984

Signature of Author

Woods Hole Oceanographic Institution-

Massachusetts Institute of Technology

Jolnt Program in Biological Oceanography,

June, 1984

Certified by

Laurence P. Madin, Thes Is Supervisor

Accepted by

Chalrman, Jqint Program in Biological Oceanography,

Wo dds Hole Oenographic Institution-Massachusetts

Institute of Technology 
This thesis is dedicated to my parents, ARMAND and ALICE CARON, and to my wife JENNIFER 
THE ILLUSION OF KNOWLEDGE

IS A BARRIER TO DISCOVERY

Related by John McN. Sieburth

15 January 1984 


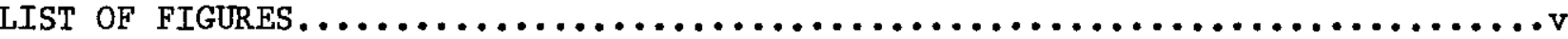

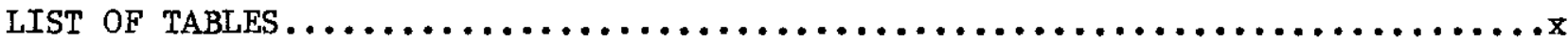

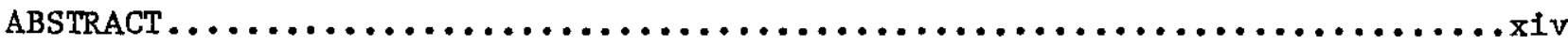

ACKNOWLEDGEMENTS..............................................

INTRODUCTION $\ldots \ldots \ldots \ldots \ldots \ldots \ldots \ldots \ldots \ldots \ldots \ldots \ldots \ldots \ldots \ldots \ldots \ldots \ldots \ldots \ldots \ldots \ldots \ldots$

CHAPTER 1. CONTRIBUTION OF HETEROTROPHIC MICROFLAGELIATES TO

PICOPLANKTON AND NANOPLANKTON COMMUNITIES IN LAKE ONTARIO

AND THE NORTH ATLANTIC............................

CHAPTER 2. MACROAGGREGATES AS MICROENVIRONMENTS OF ELEVATED MCROBIAL BIOMASS AND ACTIVITY IN THE NORTH ATLANTIC............... 54

CHAPTER 3. GROWTH OF HETEROTROPHIC MICROFLAGELLATES IN BATCH AND CONTINUOUS CULTURE AND ITS IMPLICATIONS FOR THEIR PLANKTONIC

EXISTENCE...................................... 102

CHAPTER 4. GRAZING OF ATTACHED BACTERIA BY HETEROTROPHIC MICROFLAGELIATES . . .139

CHAPTER 5. SELECTIVE GRAZING AND SURVIVAL TIMES OF ACARTIA TONSA ON PHYTOPLANKTON AND HETEROTROPHIC MICROFIAGELJATES ... . . . . . . 174

APPENDIX I. FIXATION, SAMPLE PREPARATION, AND COUNTING PROCEDURES FOR

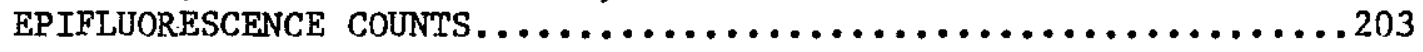

APPENDIX II. USE OF CTLTURAL AND EPIFLUORESCENCE TECHNIQUES FOR THE ENUMERATION OF BACTERIVOROUS MICROFIAGELIATES . . . . . . . . . 212

APPENDIX III. TECHNIQUE FOR ENUMERATION OF HETEROTROPHIC AND PHOTOTROPHIC NANOPLANKTON, USING EPIFLUORESCENCE MICROSCOPY, AND

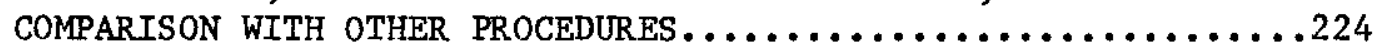

APPENDIX IV. HETEROTROPHIC BACTERIA AND BACTERIVOROUS PROTOZOA IN OCEANIC MACROAGGREGATES..........................233

APPENDIX V. CHROOCOCCOID CYANOBACTERIA IN LAKE ONTARIO: VERTICAL AND

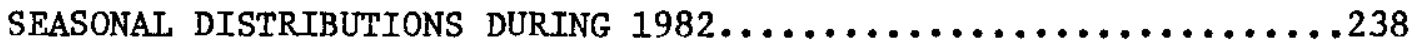

APPENDIX VI. EPIFLUORESCENCE COUNTS OF HPICO, PPICO, HNANO AND PNANO IN WATER SAMPLES FROM THE NORTH ATLANTIC AND LAKE ONTARIO.......251

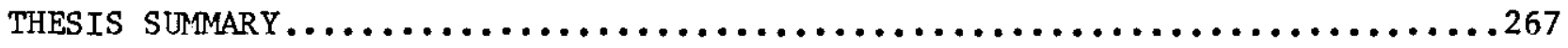


Figure I.1.

Proposed trophic link occupled by heterotrophic microflagellates

between bacteria and filter-feeding zooplankton.....................4

Figure 1.1.

Location of North Atlantic sampling stations for the picoplankton

and nanoplankton distribution study.............................

Figure 1.2.

Extent of the seasonal changes in the abundance of pico- and nanoplankton (hatched area) Inferred from 12 vertical profiles

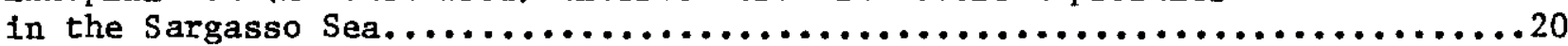

Figure 1.3.

Extent of the seasonal changes in the abundance of pico- and nanoplankton (hatched area) Inferred from five vertical profiles

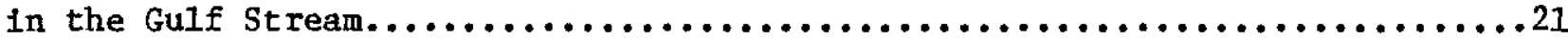

Figure 1.4.

Extent of the seasonal changes in the abundance of pico-

and nanoplankton (hatched area) inferred from six vertical

profiles in the Continental Shelf/slope environment..................22

Figure 1.5 .

Extent of the seasonal changes in the abundance of pico-

and nanoplankton (hatched area) inferred from six vertical

profiles in Lake Ontario.......................................23

Figure 1.6.

Extent of the seasonal changes in the abundance of pico- and nanoplankton (hatched area) in the summed North Atlantic stations (Figures 1.2-1.4) inferred from 23 vertical profiles In the Sargasso Sea, Gulf Stream and Continental Shelf/Slope............24

Figure 1.7.

Extent of changes in the abundance of pico- and nanoplankton

(hatched area) among vertical profiles taken at nine stations

in the Sargasso Sea during $R / V$ Atlantis II cruise $\$ 109: 3 \ldots \ldots \ldots \ldots \ldots \ldots \ldots \ldots 27$

Figure 1.8.

Extent of the changes in the abundance of pico- and nanoplankton

(hatched area) among vertical profiles taken at four stations

on the Continental Shelf/Slope during $R / V$ Oceanus cruise $\# 136 \ldots \ldots \ldots \ldots \ldots 28$

Figure 1.9.

Extent of the changes in the abundance of pico- and nanoplankton

(hatched area) among vertical profiles taken at the nearshore

and offshore stations in Lake Ontario during CSS Limnos

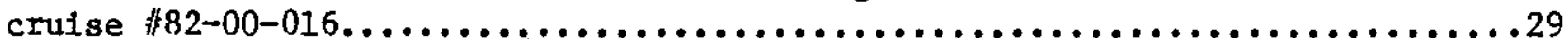


Figure 1.10.

Comparison of the seasonal ranges of pico- and nanoplankton

density in vertical profiles from the North Atlantic and

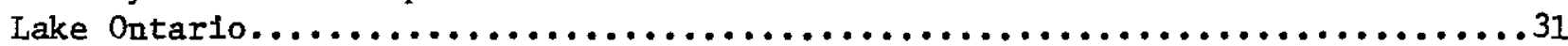

Figure 1.11.

Vertical distribution of Ppico in the Gulf Strean and Lake

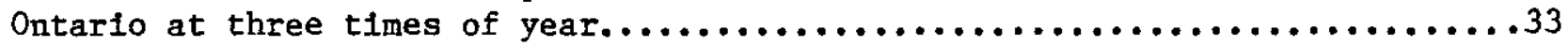

Figure 1.12 .

Numerical relationships of Hplco, Ppico, Pnano and Hnano

In representative vertical profiles from the Sargasso Sea

Continental Shelf and Lake ontario................................... 34

Figure 1.13.

Average population densities of pico- and nanoplankton in

photic waters of the North Atlantic and Lake Ontario....................

Figure 1.14 .

Numerical relationship of Hnano to other components of the pico-

and nanoplankton in four hydrographic regimes during three seasons.........37

Figure 1.15.

Biovolumes of Hpico, Ppico, Pnano and Hnano in representative

vertical profiles from the Sargasso Sea, Continental Shelf

and Lake Ontario..............................................

Figure 2.1.

Station locations for macroaggregate samples collected August

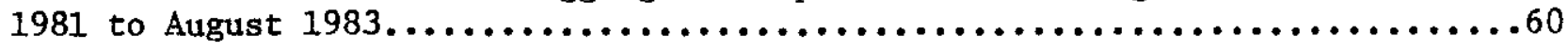

Figure 2.2.

Comparison of bacterial (Hpico) abundance on macroaggregates

and in the surrounding water with chlorophyll-a + phaeopigment

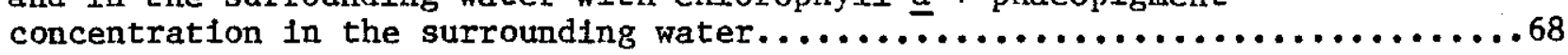

Figure 2.3.

Comparison of total nanoplankton (Tnano) abundance on

marcroaggregates and in the surrounding water with chlorophyll-a

+ phaeopigment concentration in the surrounding water.................69

Figure 2.4.

Epifluorescence photomicrographs of DAPI-stained bacteria in a

Control sample and a macroaggregate sample........................72

Figure 2.5.

Photomicrographs of cyanobacteria in macroaggregates.................73

Figure 2.6.

Transmitted white 1ight and epifluorescence photomicrographs of three species of cillates from magroaggregates showing ingested phototrophic picoplankton and nanoplankton.......................78 


\section{LIST OF FIGURES (Continued)}

Figure 2.7.

Six species of heterotrophic dinoflagellates from marine snow...........84

F1gure 2.8.

Most Probable Number estimates of bacterivorous protozoa colontzing mucus released from the ctenophores Leucothea

multicornis and Cestum veneris and incubated in 41 of unfiltered

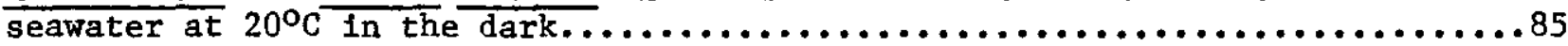

Figure 2.9.

Epifluorescence counts of bacteria and total nanoplankton colonizing discarded appendicularian houses incubated in 41 of

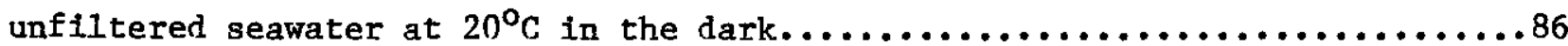

Figure 2.10.

Log-log plot of the distance between bacterla (In um) as a

function of bacterial density, using the equation adapted from

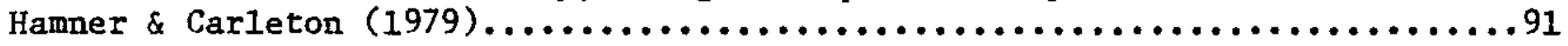

Figure 3.1.

Continuous culture apparatus used to grow the microflagellates

Monas sp. 2 and Cryptobia marts................................114

Figure 3.2.

Growth curves of Monas sp. 1 fed two species of heterotrophic

bacterta and two species of chroococcoid cyanobacteria................117

Figure 3.3.

Growth curves for Monas sp. 2 and Cryptobla maris fed Pseudomonas

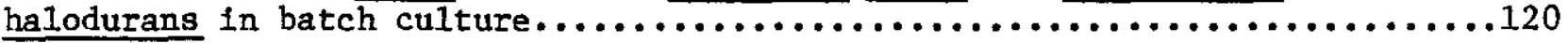

Figure 3.4 .

Population changes during a competition experiment between

Monas sp. 2 and Cryptobia maris performed in continuous culture

at a dilution rate of 0.28 day $^{-1}$.

Figure 4.1.

Epifluorescence photomicrographs of primulin-stalned

heterotrophic microflagellates assoclated with microaggregates

In a seawater sample from the Sargasso Sea.........................142

Figure 4.2.

Density of bacteria in the two culture treatments with chitin

particles in the presence of protozoan grazing..........................

Figure 4.3.

Density of bacteria in the two culture treatments with chitin

particles in the presence of protozoan grazing......................152

Figure 4.4.

The density of bacteria attached to chitin particles in the presence

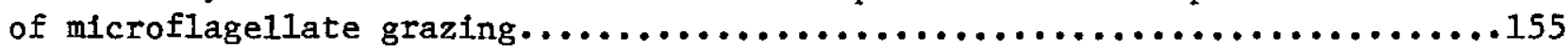


Figure 4.5 .

Eplfluorescence photomicrographs showing the grazing of bacterla attached to chitin particles by the heterotrophic microflagellate Bodo nanorensis.

Figure 4.6.

Percentage of protozoa occurring on chitin particles as shown by

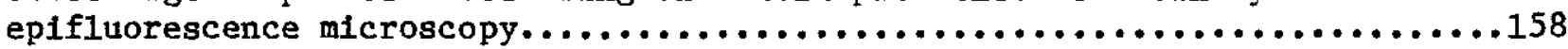

Figure 4.7.

Growth of the microflagellates Monas sp. and Rhynchomonas nasuta

on Pseudomonas halodurans grown at two concentrations of yeast

ext ract (5 $\mathrm{mg} 1^{1}$ and $50 \mathrm{mg} 1^{-1}$ ) and in the presence and

absence of chitin particles at these concentrations...................159

Figure 4.8.

Growth of the microflagellates Bodo nanorensis and Cryptobia maris

on Pseudomonas halodurans grown at two concentrations of yeast

extract ( $5 \mathrm{mg} 1^{-1}$ and $\left.50 \mathrm{mg} 1^{-1}\right)$ and in the presence and absence

of chltin particles at these concentrations.......................160

Figure 4.9.

Changes in the density of microflagellates and bacteria in the

culture vessels containing $50 \mathrm{mg} 1^{-1}$ yeast extract and chitin

particles for the microflagellates Monas sp. and Bodo nanorensis..........163

Figure 4.10.

Growth of Monas sp. and Bodo nanorensis on Pseudomonas halodurans

grown on $5 \overline{\mathrm{mg}}^{-1}$ yeast extract in the presence of chitin particles

or on $50 \mathrm{mg} 1^{-1}$ yeast extract in the presence of chitin particles.........164

Figure 5.1.

Survival of Acartia tonsa individuals fed different diets..............187

Figure AII.1.

The density of bacterivorous microflagellates estimated hy epifluorescence microscopy and the Most Probable Number culture technigue in water samples collected with Niskin bottles.............218

Figure AII.2.

The density of bacterivorous microflagellates estimated by epifluorescence microscopy and the Most Probable Number culture technique in macroscopic detrital aggregates.................................

Figure AIII. 1.

Fluorescence emission spectra of primulin, proflavine, FITC,

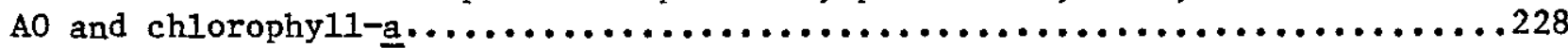

Figure AIII.2.

Epifluorescence photomicrographs of stained and unstained preparations of Micromonas sp. showing fluorochrome and chlorophyll-a fluorescence....................................229 
Figure AIV.1.

Photomicrographs of bacteria and protozoa assoclated with marine snow......236

Figure AV.1.

Vertical and seasonal distribution, and a photomicrograph of the dominant species, of chroococcoid cyanobacteria from Lake Ontario

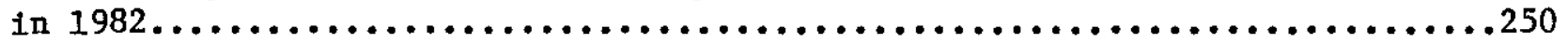


Table 1.1.

Average relative abundance of heterotrophic nanoplankton to other pico- and nanoplankton components in the photic and aphotic zone

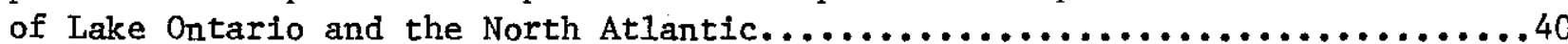

Table 1.2.

Most Probable Number estimates of the bacterivorous protozoa in samples obtained in acid-rinsed Niskin bottles form the

North Atlantic and Lake Ontario...............................42

Tab1e 1.3.

Comparison of the Most Probable Number estimates (MPN) of

flagellated protozoa and epifluorescence counts (DC) of heterotrophic

nanoplankton (expressed as percent of direct counts accounted

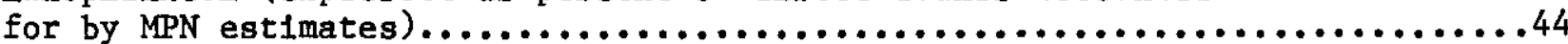

Table 2.1.

Epifluorescence counts of plcoplankton, nanoplankton, and algae

greater than $20 \mathrm{um}$ in Control and N1skin Bottle samples from surface

waters of the North Atlantic...................................65

Table 2.2.

Epifluorescence counts of picoplankton, nanoplankton, and algae

greated than 20 um in macroaggregates from surface waters of

the North Atlantic.........................................66

Table 2.3.

Enrichment factors for picoplankton, nanoplankton, and algae greater

than $20 \mathrm{um}$ in macroaggregates from surface waters of the North

Atlantic.................................................70

Table 2.4.

Most Probable Number estimates of protozoa in macroaggregates from

surface waters of the North Atlantic............................76

Table 2.5.

Enrichment factors for bacterivorous protozoa in macroaggregates

from surface waters of the North Atlantic............................. 79

Table 2.6.

A comparison of the number of heterotrophic microflagellates in

macroaggregate and Control samples as shown by the Most Probable

Number culture technlque and by direct (eplfluorescence) counts...........8I

Table 2.7.

Carbon:nitrogen ratios of mucus release by ctenophores held

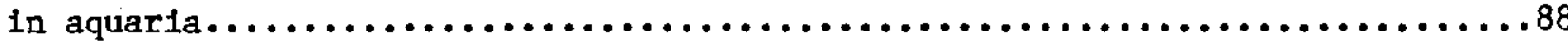

Table 2.8.

Carbon:nitrogen ratios of macroaggregates collected from surface

waters of the North Atlantic......................................8 
Table 2.9.

Average population densities and enrichment factors for two

Rhizosolenia mats collected in the Sargasso Sea, $8 / 28 / 81 \ldots \ldots \ldots \ldots \ldots \ldots \ldots \ldots 9$

Table 3.1.

Growth rates, doubling times and cell ylelds of the microflagellate

Monas sp. 1 grown on two species of heterotrophic bacteria and

two species of chroococcold cyanobacteria.......................118

Table 3.2.

Growth parameters of Monas sp. 2 and Cryptobla maris in batch culture......121

Table 3.3.

Growth and feeding parameters of Monas sp. 2 and Cryptobia maris

in continuous culture......................................123

Table 3.4.

Ranges of the estimated clearance rates of microflagellate

populations in-situ and the resulting minimum doubling times of

bacterioplankton calculated from various studies....................132

Table 5.1.

Inltial densities and blovolumes of the food organisms employed in

the Acartia tonsa survival experiment..

Table 5.2.

Mean survival time, median survival times, and maximum individual

survival times for Acartia tonsa fed different diets..................186

Table 5.3.

Results of a selective grazing experiment with Acartla tonsa where

the copepods were offered 2-member mixtures of prey organisms;

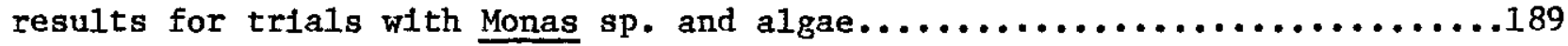

Table 5.4.

Results of a selective grazing experiment with Acartla tonsa where

the copepods were offered 2-member mixtures of prey organisms;

results for trials with Cryptobla marls and algae.....................190

Table 5.5.

Results of a selective grazing experiment with Acartia tonsa where

the copepods were offered 2-member mixtures of prey organisms;

results for trials with protozoa only or algae only.................191

Table AI.1.

Comparison of the acridine orange technique and the "dried

Millipore filter" technique for counting phototrophic and

heterotrophic nanoplankton.................................209

Table AII.1.

Most Probable Number estimates of bacterivorous microflagellates

using various substrates to enrich the natural bacterial flora...........215 
Table AII.2.

Estimates of the number of microflagellates in cultures as determined by the Most Probable Number culture technique and direct counts by eplfluorescence microscopy.

Table AIII. 1.

Comparison of direct counts (by the primulin technique and with

a hemacytometer) of clonal cultures for five species of photosynthetic flagellates and elght spectes of heterotrophic flagellates.............229

Table AIII.2.

Counts of photosynthetic, heterotrophic and total nanoplankton for

four nearshore and six oceanic stations.........................230

Table AIV.1.

Direct microscoplc counts and Most Probable Number cultural estimates of the microorganisms present on macroaggregates sampled at three stations in the southern Sargasso Sea............................235

Table AV.1.

Population density, biomass and percent of the population observed in size-fractionated samples of the picoplankton and nanoplankton

from Lake Ontario on 28 April and 24 August 1982......................248

Table AVI.1.

Epifluorescence counts of Hplco, Ppico, Pnano and Hnano in vertical

profiles performed during $R / V$ Columbus Iselin cruise $\$ 83-01 \ldots \ldots \ldots \ldots \ldots . \ldots 253$

Table AVI.2.

Eplfluorescence counts of Hpico, Ppico, Pnano, and Hnano in vertical

profiles performed during $R / V$ Oceanus cruise $\# 115 . \ldots \ldots \ldots \ldots \ldots \ldots \ldots \ldots \ldots . \ldots 254$

Table AVI.3.

Eplfluorescence counts of Hpico, Ppico, Pnano and Hnano in vertical

profiles performed during $R / V$ Knorr cruise $\$ 194 \ldots \ldots \ldots \ldots \ldots \ldots \ldots \ldots \ldots \ldots . \ldots \ldots 5$

Table AVI.4.

Epifluorescence counts of Hpico, Ppico, Pnano and Hnano in vertical

profiles performed during $R / V$ Oceanus crulse $\$ 136 \ldots \ldots \ldots \ldots \ldots \ldots \ldots \ldots \ldots \ldots . \ldots 257$

Table AVI.5.

Epifluorescence counts of Hplco, Ppico, Pnano and Hnano in vertical

profiles performed during $R / V$ Atlantis II cruise $\# 109: 3 . \ldots \ldots \ldots \ldots \ldots \ldots . \ldots 259$

Table AVI.6.

Epifluorescence counts of Hpico, Ppico, Pnano and Hnano in vertical profiles performed in Lake Ontario on 28 April and 29 April 1982..........262

Table AVI.7.

Epifluorescence counts of Hpico, Ppico, Pnano and Hnano in vertical

profiles performed in Lake Ontario on 28 June and 29 June 1982. 
Table AVI.8. Epifluorescence counts of Hpico, Ppico, Pnano and Hnano in vertical profiles performed in Lake Ontario on 23 August and 24 August 1982. 
THE ROLE OF HETEROTROPHIC MICROFLAGELLATES

IN PLANKTON COMMUNITIES

by

DAVID A. CARON

\author{
Submitted to the Woods Hole Oceanographic Institution \\ and Massachusetts Institute of Technology \\ in partlal fulfillment of the requirements \\ for the degree of Doctor of Philosophy
}

\begin{abstract}
The distribution and feeding behavior of bacterivorous microflagellates (2-20 um protozoa) and their ingestion by copepods were examined in an attempt to assess the importance of these protozoa as a trophic link between planktonic bacterla and zooplankton. The abundance of microflagellates relative to other picoplankton $(0.2-2.0 \mu \mathrm{m})$ and nanoplankton $(2-20 \mu \mathrm{m})$ populations in water samples in the North Atlantic and in Lake Ontario and on macroaggregates in the North Atlantic was determined using direct microscopical and culture estimation techniques. Seasonal, vertical and geographical changes in the denstty of microflagellates were generally not greater than one order of magnitude. Microscoplcal counts of heterotrophic nanoplankton (presumably microflagellates) typically ranged from a few hundred to a few thousand $\mathrm{ml}^{-1}$ for a variety of planktonic environments. They constituted approximately $1 / 3$ to $1 / 2$ of the nanoplankton in the euphotic zone and dominated the nanoplankton in the aphotic zone. Most Probable Number
\end{abstract}


(MPN) estimation of the density of bacterivorous protozoa indicated that microflagellates were, on average, an order of magnitude more abundant than bacterivorous ciliates and amoebae. MPN and direct microscopical counts of microflagellates differed by as much as $10^{4}$. This discrepancy was smaller in eutrophic environments (e.g. Continental Shelf and Lake Ontario) and on macroscopic detrital aggregates.

All microbial populations enumerated were highly concentrated on macroscopic detrital aggregates relative to their abundance in the water surrounding the aggregates. Enrichment factors (the ratio of abundance of a population on a macroaggregate to its abundance in the surrounding water) Increased along a eutrophic-to-ollgotrophic gradient because of the combined effects of an 1ncreased abundance of microorganisms on macroaggregates in oligotrophic environments and a decreased abundance in the surrounding water In these same environments. Average enrichment factors for direct microscopical counts of heterotrophlc nanoplankton (range $=17-114$ ) were not as large as enrichment factors observed for MPN estimates of the number of bacterlvorous microflagellates (range $=273-18400$ ). Microflagellates numerically dominated the bacterlvorous protozoa cultured from macroaggregates by one to two orders of magnitude, but clllates and amoebae were also highly enriched on macroaggregates. Microenvironments are therefore a potentially important aspect for the ecology of planktonlc microorganisms. Observations on the microbial colonization of mucus sloughed by ctenophores and discarded appendicularian houses suggest that these materials may be important sources of macroaggregates.

Batch and continuous culture experiments were conducted with clonal cultures of microflagellates to test their ability to grow on varlous types and densities of bacteria. The doubling time of Monas sp. 1 ranged from $43 \mathrm{hr}$ (when fed the cyanobacterlum Synechococcus Strain WH 8101) to $6.9 \mathrm{hr}$ (when fed 
the heterotrophic bacterium Serratia marinorubra). Cell yields (i.e. the conversion of bacterial biomass into protozoan biomass) of Monas sp. 1 fed two species of heterotrophic bacteria were greater than yields for the microflagellate fed two species chroococcoid cyanobacteria (range $=7-68 \%$ ). Cell ylelds of two other spectes of microflagellates (Monas sp. 2 and Cryptobla maris) were $48 \%$ and $61 \%$, respectively, on the bacterlum Pseudomonas halodurans. Microflagellates grew in continuous culture at concentrations of bacterla which were lower than bacterlal densities required for the growth of c1liates as shown by other investigations. Therefore, microflagellates appear to be well-adapted for grazing bacterioplankton.

Microflagellates were also investigated for their ability to graze bacteria attached to particles. Bodo nanorensis and Rhynchomonas nasuta both showed a marked abllity to graze attached bacteria and a limited ability to graze unattached cells. These results suggest that microflagellates may also be important consumers of bacteria attached to particles in the plankton and may explain the highly elevated densities of microflagellates on macroaggregates.

Grazing experiments performed with the copepod Acartia tonsa indicated that heterotrophic microflagellates were ingested by the copepods at rates comparable to the ingestion of phytoplankton of similar size. The presence of heterotrophic microflagellates did not depress filtration rates of the copepods, and one species (Cryptobla maris) appeared to be selectively grazed. Survival of $\mathrm{A}$. tonsa on a diet of heterotrophic microflagellates was similar to survival on a diet of phytoplankton and was significantly longer than survival of starved Controls or copepods fed only bacterla.

Due to their ability to grow at in-situ densities of planktonic bacteria, their relatively high cell yields, and their acceptability as food for zooplankton, it is concluded that bacterivorous microflagellates may 
constitute an important trophic link between bacteria and zooplankton. This link may provide a mechanism whereby organic material and energy from the detrital food chain can be returned to the classical phytoplanktoncopepod-fish food chain. 


\section{ACKNOWLEDGEMENTS}

Five years of work cannot be accomplished without the patience, guidance and assistance of many people. My research has certainly been no exception to this rule.

I would first like to acknowledge those people who have most influenced my professional development. My sincere thanks go first to Dr. Laurence P. Madin for his continued support and guidance throughout this endeavor. A more understanding and competent advisor does not exist. Larry has allowed me a large degree of freedom to pursue my interests and yet he has always remained easily approachable for advice, suggestions and (not least of all) logistical and financial support. His keen insight and open manner have provided a valuable classroom which I have greatly appreciated and immensely enjoyed.

Dr. John McN. Sieburth, who was my mentor at the University of Rhode Island for a previous degree, has also been a major force in my professional development. John possesses a boundless (and contagious) enthusiasm for scientific research. His innovative ideas and experimental approaches have instilled in me the need to continually question my experimental design and to always consider alternative interpretations of my data.

I would also like to acknowledge the many people from whom I have recelved assistance during this study. Dr. Paul G. Davis has continued to be a close personal friend as well as a hlghly valued coworker since our first collaborative effort in 1975. Innumerable discussions with Paul concerning the ecology of planktonic protozoa have had a great impact on my own thoughts on how plankton communities function and have undoubtedly had effects on the design of my research. I greatly respect his knowledge and value his friendship. I am also grateful to Dr. David R.S. Lean for his interest in my work and his offer to participate in his Lake Ontario Nutrient Assessment Study. Dave provided the opportunity to investigate the pico- and 
nanoplankton of the Lake. I am also indebted to my thesis committee for helpful suggestions and comments on experimental design and presentation of the results, and to the many people too numerous to mention who assisted with the collection of samples. I am especially grateful to the residents of Redfield 230, Catherine Cetta, Gregg Dietzmann and Carol Diebel who have made my work so enjoyable.

In addition to the intangible support which I have recelved throughout my work, several people have contributed portions of data for which I am greatly appreclative. Dr. Paul G. Davis provided the epifluorescence counts of plcoplankton, nanoplankton and algae greater than $20 \mu \mathrm{m}$ for macroscopic detrital aggregates collected on Atlantis II (cruise \#109:3) and Oceanus (crulse \#115). Chlorophyl1-a and phaeopigment data were kindly provided by Dr. Patricia G1ibert (Knorr cruise \#94), Catherine Cetta (Oceanus cruise \#115) and Dr. Todd Kana (Oceanus cruise $\# 136$ ). Analysis of macroaggregate samples for carbon, hydrogen and nitrogen were performed by Bonnie Woodward. I am also Indebted to Drs. John B. Waterbury and TImothy J. Cowles who graclously loaned me equipment for this study.

Finally, it is difficult to adequately express my gratitude to my parents, family and, of course, my wife Jennifer. Their unwalvering support of my research, despite an understandably nominal grasp of the subject matter, has been my greatest source of strength throughout these five years. The completion of this dissertation is due in large part to their confidence in me.

This research was supported by National Science Foundation grants OCE80-24441 and OCE82-14928 and Ocean Industry Program grant 4473 awarded to Dr. Laurence P. Madin, NSF Doctoral Dissertation grant 0CE81-12991, the Woods Hole Oceanographic Institution Education Program and the Wood Hole Oceanographic Institution Blology Department. 


$$
-1-
$$

INTRODUCTION 
The last 10 years has witnessed a reevaluation of the paradigm of how plankton communities function. The phytoplankton-copepod-fish food chain is no longer a complete or accurate account of trophic interactions or energy flow among the plankton. It is now believed that a very significant fraction of the energy flow in plankton communities is mediated by picoplankton (microorganisms $0.2-2.0 \mu \mathrm{m}$ in size, primarlly bacterla and chroococcold cyanobacteria) and nanoplankton (microorganisms 2.0-20 $\mathrm{mm}$ in size, primarily phototrophic and heterotrophic eucaryotes). Recent estimates suggest that $20-80 \%$ of the primary productivity in the ocean eventually passes through the bacteria (Pomeroy, 1974; Sieburth et al., 1977; Sorokin et al., 1977; Larsson \& Hagstrom, 1979; Fuhrman \& Azam, 1980; Williams, 1981). In addition, it has been noted that phototrophic nanoplankton, and more recently phototrophic picoplankton (chroococcoid cyanobacteria and minute eucaryotes), often dominate the standing crop of phytoplankton and primary productivity of plankton communities (McCarthy et al., 1974; Johnson \& Sleburth, 1982; L1 et a1., 1983; Platt et a1., 1983; Takahash1 \& Hor1, 1984).

Along with a better understanding of the importance of microorganisms in plankton communities has come the realization that heterotrophs compose a significant fraction (approximately 50\%) of the nanoplankton (Davis et al., submitted; Haas, 1982; Caron, 1983). This observation is not a new one. Large numbers of heterotrophic microflagellates have been documented for nearly 50 years (Hentsche1,1936). Non-photosynthetic representatives have been described from virtually all major phytoplankton taxa, and several Important groups of flagellated protozoa have been described from the plankton. Not unt1l recently, however, has a concerted effort been initiated to determine the role which the heterotrophic nanoplankton play in plankton communities. Present studies now suggest that these microorganisms are important consumers of picoplankton, and may be the primary agent controlling 
the density of bacterla in plankton communities. In addition, these protozoa convert bacterial blomass into their own blomass, this making it available to higher organisms. This activity may be of particular ecological importance below the photic zone where the influence of primary producers is reduced (Harding, 1974). In this environment they may serve as a vital link between bacterial production from dissolved and particulate organic matter, and higher organisms (S1eburth, 1979).

An 1mportant role for heterotrophic microflagellates in the marine food web has been proposed despite the existence of only scant amounts of data to substantiate the hypothesis. This dissertation is an attempt to add to several aspects of our understanding of the role of heterotrophic microflagellates in plankton communities. It is composed of five manuscripts which deal with separate but related topics on their ecology. The seasonal and spatial (geographic and vertical) distribution of heterotrophic microflagellates in the North Atlantic and Lake Ontario are described in Chapter 1. Its purpose is to document the density of microflagellates in the oceanic environment, to determine the contribution of these protozoa relative to the standing crop of other nanoplankton and picoplankton populations, and to indicate similarities between pico- and nanoplankton of freshwater and marine environments.

The four remaining manuscripts deal with specific aspects of microflagellate ecology and are summarized in Figure I.1. This Figure depicts a highly simplified view of the potential trophic relationships of heterotrophic microflagellates with other planktonic organisms. Question marks indicate the areas of study which are addressed in this dissertation. The left hand side of Figure I.I indicates the relationship between microflagellates and their bacterlal prey. The role of microflagellates as bacterlal grazers is examined in two chapters. Chapter 3 describes grazing 
Figure I.1. Proposed trophic Iink occupied by heterotrophic microflagellates between bacterla and filter-feeding zooplankton. 


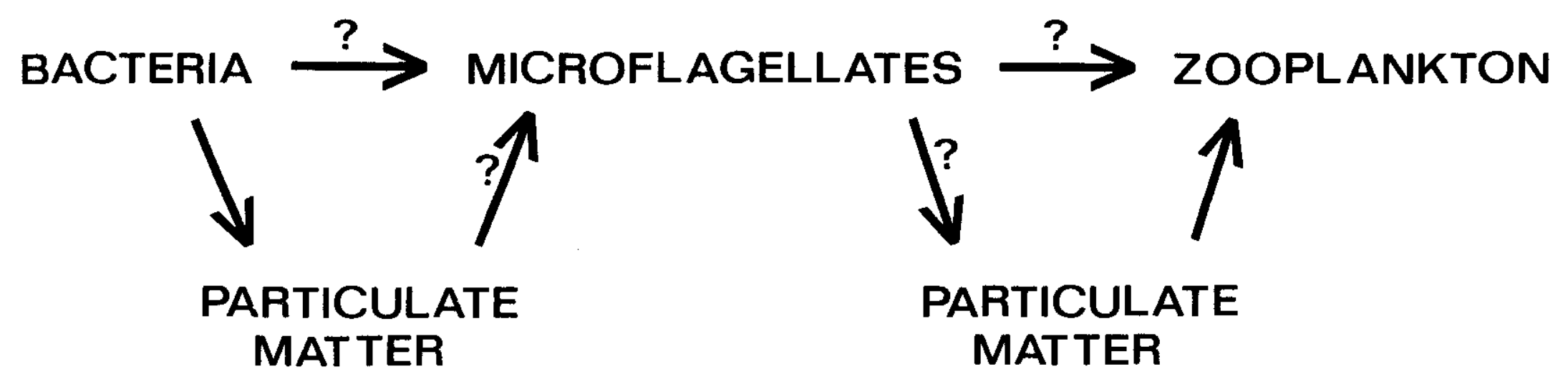


rates, growth rates and conversion efficiencles of cultured microflagellates feeding on free-living (unattached) bacterla. This study was designed to determine the ability of microflagellates to graze planktonic bacteria. Chapter 4 describes the ability of cultured microflagellates to graze bacterla attached to particles. It discusses the 1mplications of this behavior for the colonization of particles by bacteria and as an explanation for the planktonic existence of bacterivorous protozoa.

The right hand side of Figure I.1 deals with the avallability of microflagellates as food for zooplankton species. These protozoa may be available directly to filter-feeding organisms capable of removing them from suspension, or by their association with larger particles. Chapter 2 documents the abundance of heterotrophic microflagellates (and other nano- and picoplankton components) on macroscopic detrital aggregates from surface waters of the North Atlantic. This chapter follows the distribution study since population densities on macroaggregates are large enough that these microcommunities may be important in the overall distribution and ecology of these protozoa. Chapter 5 describes experiments which test the ability of the calanold copepod Acartia tonsa to select between phototrophic flagellates and heterotrophic microflagellates when offered mixtures of algae and protozoa. In addition, the survival of $\underline{A}$. tonsa fed only protozoa or only algae was examined.

Three appendices also contain manuscripts pertinent to the ecology of heterotrophic microflagellates. Appendix III is a manuscript published in Applied and Environmental Microbiology (1983; 46: 491-498) which compares existing techniques and proposes a new one for counting heterotrophic nanoplankton using epifluorescence microscopy. Appendix IV is a manuscript published in Sclence (1982; 218: 795-797) which contains preliminary information on the occurrence of microorganisms on macroscopic detrital 
aggregates. Appendix $\mathrm{V}$ is a manuscript in preparation describing the seasonal and vertical distribution of chroococcoid cyanobacteria in Lake Ontario and their potential importance in primary productivity and phosphorus uptake in the Lake. 
REFERENCES

Caron, D.A. 1983. Technique for enumeration of heterotrophic and phototrophic nanoplankton using epifluorescence microscopy, and comparison with other procedures. App1. Environ. Microbiol. 46: 491-498. Davis, P.G., D.A. Caron, P.W. Johnson \& J.McN. Sieburth. Submitted. Geographic, seasonal and diel distribution of phototrophic and heterotrophic components of the picoplankton and nanoplankton in the North Atlantic. Mar. Ecol. Prog. Ser.

Fuhrman, J.A. \& F. Azam. 1980. Bacterioplankton secondary production estimates for coastal waters of British Columbia, Antarctica, and California. Appl. Environ. Microbiol. 39: 1085-1095.

Haas, L.W. 1982. Improved epifluorescence microscopy for observing planktonic micro-organisms. Ann. Inst. oceanogr., Paris 58(S): 261-266.

Harding, G.C.H. 1974. The food of deep-sea copepods. J. mar. biol. Ass. U.K. 54: 141-155.

Hentsche1, E. 1936. Die blologischen Methoden und das blologische Beobachtungsmaterlal der Meteor Expedition. Wiss. Ergeben. dt. altant. Exped. 'Meteor' 10: 274pp.

Johnson, P.W. \& J.McN. Sieburth. 1982. In situ morphology and occurrence of eucaryotic phototrophs of bacterial size in the picoplankton of estuarine and oceanic waters. J. Phycol. 18: 318-327.

Larsson, U. \& A. Hagstrom. 1979. Phytoplankton exudate release as an energy source for the growth of pelagic bacterla. Mar. B1ol. 52: 199-206.

Li, W.K.W., D.V. Subba Rao, W.G. Harrison, J.C. Smith, J.J. Cullen, B. Irwin \& T. Platt. 1983. Autotrophic picoplankton in the tropical ocean. Sclence 219: 292-295.

McCarthy, J.J., W.R. Taylor \& M.E. Loftus. 1974. Significance of 
nanoplankton in the Chesapeake Bay Estuary and problems associated with the measurement of nanoplankton productivity. Mar. Biol. 24: 7-16.

Platt, T., D.V.S. Rao. \& B. Irwin. 1983. Photosynthesis of picoplankton in the oligotrophic ocean. Nature 301: 702-704.

Pomeroy, L.R. 1974. The ocean's food web, a changing paradigm. Blosclence 24: 499-504.

Sleburth, J.McN. 1979. Seamicrobes. Oxford Univers1ty Press, New York, 491pp.

Sleburth, J.McN., R.M. Johnson, C.M. Burney \& D.M. Lavole. 1977. Estimation of in-situ rates of heterotrophy using diurnal changes in dissolved organic matter and growth rates of picoplankton in diffusion culture. Helgolander wi.ss. Meeresunters. 30: 565-574.

Sorokin, Y.I., E.B. Pavelyeva \& M.I. Vasilyeva. 1977. Productivity and the trophic role of bacterloplankton in the region of equatorlal divergence. Pol. Arch. Hydrobiol. 24(S): 241-259.

Takahash1, M. \& T. Hor1. 1984. Abundance of plcophytoplankton in the subsurface chlorophyll maximum layer in subtropical and tropical waters. Mar. Biol. 79: 177-186.

Williams, P.J. 1eB. 1981b. Incorporation of microheterotrophic processes Into the classical paradigm of the planktonic food web. Kleler Meeresforsch. 5: 1-28. 
$-9-$

CHAPTER 1

CONTRIBUTION OF HETEROTROPHIC MICROFLAGELLATES

TO PICOPLANKTON AND NANOPLANKTON COMMUNITIES

IN LAKE ONTARIO AND THE NORTH ATLANTIC 


\section{ABSTRACT}

Phototrophic and heterotrophic plcoplankton and nanoplankton were counted at two stations in Lake Ontario and 23 stations in the North Atlantic during the winter, spring and sumer. Absolute abundances of pico- and nanoplankton In Lake Ontario reached greater maxima than those observed in the ocean, but the range of densities in both environments strongly overlapped. Seasonal changes in the abundance of microorganisms in Lake Ontario mirrored changes in the Continental Shelf/Slope environment of the North Atlantic. Phototrophic picoplankton (primarily chroococcoid cyanobacteria) was numerically the most variable population. The density of these microorganisms changed by three orders of magnitude over a seasonal cycle. The density of heterotrophic picoplankton (primarily bacterla) varied by approximately one order of magnitude while shifts in nanoplankton abundance on a seasonal basis were approximately 1.5 orders of magnitude.

Small-scale spatial varfability in the abundance of pico- and nanoplankton was as large as seasonal shifts in abundance. For example, changes in the abundances of pico- and nanoplankton with depth generally exceeded seasonal changes in abundance during periods of thermal stratification. Changes in abundance between stations within one hydrographic regime (1.e. Sargasso Sea, Gulf Stream, Continental Shelf/Slope, Lake Ontario) during one season were also of the same magnitude as seasonal changes in that environment.

Heterotrophic nanoplankton contributed significantly to both freshwater and oceanic environments at all stations and in all seasons. Most Probable Number estimation of the density of bacterivorous protozoa indicated increasing density of these microorganisms along an offshore-to-inshore gradient for the marine samples. Average MPN estimates of Lake Ontario exceeded those of the oceanic environment. Despite differences in the absolute abundance of pico- and nanoplankton, relative abundances of these 
populations were similar for freshwater and marine samples. This observation may indicate similar trophic relationships between these microorganisms for both environments. This study indicates a high degree of similarity between the plankton of Lake Ontario and the North Atlantic at this level of comparison. 


\section{INTRODUCTION}

The 1mportance of picoplankton (0.2-2.0 um in size) and nanoplankton (2.0-20 um in size) in marine and freshwater communities has been firmly established in recent years. Both of these operationally-defined plankton classes (Sieburth et al., 1978) contain autotrophic and heterotrophic populations which play a large role in nutrient and energy cycling in the environment. It has been demonstrated that most of the total community respiration (Pomeroy \& Johannes, 1968; Will1ams, 1981a) and nutrient regeneration (Harrison, 1978; Glibert, 1982; Paasche \& Kristiansen, 1982) in the marine environment may take place in this size fraction.

The presence of large standing stocks of heterotrophic nanoplankton (Hnano) In the ocean has been documented for nearly 50 years (Hentschel, 1936). Nevertheless, not until recently have studies been undertaken to determine the distribution of these microorganisms. The heterotrophic nanoplankton are largely composed of microflagellates which feed phagotrophically on picoplankton or other nanoplankton (Chapter 3; Haas \& Webb, 1979; Davis, 1982; Fenche1, 1982a; Haas, 1982; Sherr et a1., 1983). Traditional sampling and counting techniques have tended to minimize the importance of these microorganisms in plankton communities, or have omftted counts of them altogether. The inadequacy of classical counting techniques for the enumeration of heterotrophlc nanoplankton has been discussed by Caron (1983; see Appendix III).

A substantial 1iterature has appeared in the last few years concerning the distribution of Hnano in marine systems. This literature indicates relatively large standing stocks of Hnano in the ocean (Vinogradov et al., 1976; Tumantseva \& Sorokin, 1977; Sorokin \& Kogelschatz, 1979; S1lver et a1., 1980; Sorokin, 1981; Tumantseva, 1981, Davis \& Sleburth, 1982; Caron 1983; Sherr \& Sherr, 1983; Davis et al., submitted). A similar situation appears to exist 
In freshwater environments although very few data are avallable (Appendix V; Hilliard, 1971). Heterotrophic nanoplankton may constitute one half of the total nanoplankton population (Davis \& Sleburth, 1982; Caron, 1983; Sherr \& Sherr, 1983). Their densities have been shown to be correlated with dissolved carbohydrate concentrations, as we1l as the density of heterotrophic picoplankton and phototrophic nanoplankton (Burney et al., 1981; Davis, 1982; Linley et al., 1983; Sherr et al., 1984). Their abundance and activity as bacterlal grazers has prompted several investigators to incorporate the Hnano into models describing energy flow in plankton communities (Sorokin, 1981; W11liams, 1981b; Azam et al., 1983; Laacke et al., 1983).

While a number of investigations have now documented the ubiquity of Hnano In the pelagic environment, few studies have attempted to compare changes in their abundance with changes in the abundance of other pico- and nanoplankton components (Burney et al., 1981; Fenchel, 1982d; Linley et al., 1983; Dav1s et a1., submitted). Only one study has enumerated the full spectrum of pico- and nanoplankton and the correlation of these populations with Hnano (Davis et al., submitted). This "plece meal" approach has occurred in spite of the obvious trophic relationships between Hnano and other components of the picoand nanoplankton, and the existence of we11-estab11shed procedures for counting these populations.

The picoplankton consists of phototrophic and heterotrophic microorganisms (primar1ly procaryotes) which are belleved to be the main food source for heterotrophic microflagellates. Heterotrophic picoplankton (Hpico) consists primar1ly of heterotrophic bacteria (and perhaps chemoltthotrophic bacteria). Large standing stocks of Hpico in marine and freshwater communfties have been realized primarily through the use of epifluorescence microscopy (Watson et al., 1977; Porter \& Felg, 1980). This technique has also been useful for Identifying and enumerating phototrophic picoplankton (Ppico) which is 
composed primarily of chroococcoid cyanobacteria (Johnson \& Sieburth, 1979; Waterbury et al, 1979) and minute eucaryotes (Johnson \& Sieburth, 1982; Takahashi \& Hor1, 1984). This community constitutes an important part of the primary production of oceanic waters ( $\mathrm{Li}$ et al, 1983; P1att et al., 1983), and may also be important in freshwater plankton communities (Caron et al, ; Appendix V).

The importance of phototrophic nanoplankton (Pnano), primar1ly microflagellates and small dlatoms, was underestlmated for many years. Numerous studies have now shown that these microorganisms dominate the phytoplankton of a wide range of marine and freshwater environments (Munawar et al, 1974; Beers et a1., 1975; Munawar \& Munawar, 1975; Brocke1, 1981; Beers et al., 1982; Booth et al., 1982). Only recently have attempts been made to determine the relative Importance of Ppico and Pnano as primary producers, however, and thus the contribution of Pnano to the total system primary productivity is once again unclear.

Few data are available concerning the distributon of phototrophic and heterotrophic pico- and nanoplankton in the ocean. However, even less is known concerning the distribution of these populations in freshwater. There Is no a priori reason to assume that these systems function differently, but no detailed comparisons of these environments have been performed. Comparison of freshwater and oceanic communities should provide information on the abundance of heterotrophic microflagellates relative to other pico- and nanoplankton, and thus indicate whether or not microflagellates might be as important in freshwater environments as has been proposed for marine systems.

Plcoplankton and nanoplankton were examined in Lake Ontario and the North Atlantic over a two year perfod. Population counts of Hplco, Ppico, Hnano and Pnano were made using epifluorescence microscopy. Relative abundances of pico- and nanoplankton in Lake Ontario were comparable to those in the North 
Atlantic, although absolute abundances in the Lake were slightly greater than in the North Atlantic. The contribution of heterotrophic microflagellates was assessed by both a direct counting technique and by a Most Probable Number culture technique. The results suggest that at this level of observation the $<20 \mu \mathrm{m}$ plankton of Lake Ontarto is strikingly analogous, although somewhat more eutrophic, to the plankton of the North Atlantic. 
METHODS AND MATERIALS

Samples were collected from two stations in Lake Ontario and from 23 stations in the North Atlantic. Stations were located north-centrally $\left(43^{\circ} 53^{\prime} 39^{\prime \prime} \mathrm{N}, 78^{\circ} 15^{\prime} 34^{\prime \prime} \mathrm{W}\right.$; "nearshore" station) and centrally $\left(43^{\circ} 35^{\prime} 39^{\prime \prime} \mathrm{N}\right.$, $78^{\circ} 13^{\prime} 16^{\prime \prime} \mathrm{W}$; "offshore" station) in Lake Ontario. Bottom depths were approximately $38 \mathrm{~m}$ and $177 \mathrm{~m}$ for these two stations, respectively. Samples were collected from both stations in Lake Ontario on 28-29 Apri1 1982, 28-29 June 1982 and 23-24 August 1982). These sampling times corresponded to perlods when the surface water temperature at the two stations was near its minimum $\left(1.6\right.$ and $\left.2.7^{\circ} \mathrm{C}\right)$, during the spring warming $\left(5.8\right.$ and $13.5^{\circ} \mathrm{C}$ ), and near its maximum $\left(15.0\right.$ and $\left.15.5^{\circ} \mathrm{C}\right)$, respectively. Water temperature was isothermal at the time of the April sampling, but thermoclines were present during June and August.

Station locations for the North Atlantic are given in Figure 1.1. Samples were collected from each of three oceanographic regimes (Sargasso Sea, Gulf Stream, Continental Shelf/ Slope) during the winter, spring and summer (see Appendix VI for individual sampling dates). Symbols in Figure 1.1 indicate the location of the stations relative to the Sargasso Sea and eastern North Atlantic (collectively referred to as "Sargasso Sea" samples in the Results and Discussion), Gulf Stream, and Continental Shelf/Slope. Samples were obtained on five oceanographic cruises over a two year period ( $R / V$ Atlantis II cruise \#109:3, 12 Aug to 11 Sept 1981; R/V Oceanus cruise \#115, $16 \mathrm{Feb}$ to 5 Mar 1982; R/V Knorr crulse \#94, 18 May to 6 June 1982; R/V Columbus Iselin cruise \#83-01, 19 Feb to 12 Mar 1983; R/V Oceanus cruise \#137, 12 Aug to 25 Aug 1983).

Vertical profiles were made at each station by collecting samples in acid-rinsed ( $0.1 \mathrm{~N} \mathrm{HCl)} \mathrm{Niskin} \mathrm{bottles.} \mathrm{Samples} \mathrm{for} \mathrm{epifluorescence} \mathrm{microscopy}$ were preserved with filtered glutaraldehyde at a final concentration of $1 \%$. 
Figure 1.1. Location of sampling stations in the North Atlantic. Squares, clrcles and diamonds indicate Sargasso Sea stations, Gulf Stream stations and Continental Shelf/Slope stations, respectively. Dates, locations and epifluorescence counts are given for individual stations in Appendix VI.

(D) Sargasso Sea

(D) Gulf Stream

$(\diamond)$ Continental Shelf/slope 


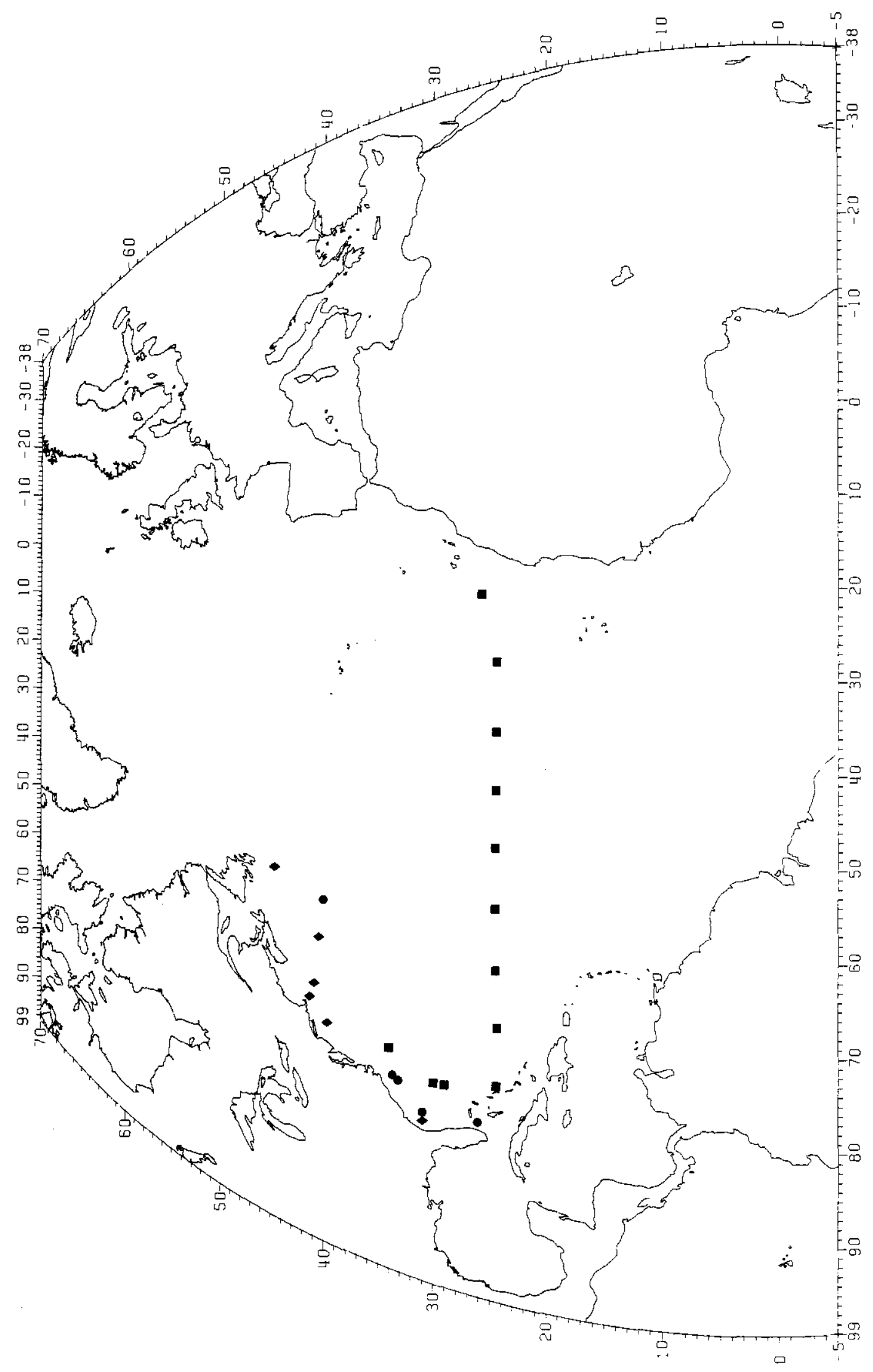


Samples were examined for the density of phototrophic picoplankton (primarily chroococcoid cyanobacteria), heterotrophic picoplankton (heterotrophic bacteria), and phototrophic and heterotrophic nanoplankton. Preparation and counting techniques are given in Appendix I. Population densities determined by epifluorescence microscopy were converted to blovolume estimates for three vertical profiles (see Figure 1.15) based on average cell dimensions for each population. For Hplco, cells were counted as "cocci" or "rods". Volumes of $0.065 \mathrm{um}^{3} \mathrm{cel1}^{-1}$ for cocc1 (average diameter of $0.4 \mu \mathrm{m}$ ) and $0.088 \mu \mathrm{m}^{3}$ $\operatorname{cell}^{-1}$ for rods (average dimensions of $0.4 \mathrm{x} 0.7 \mu \mathrm{m}$ ) were used to convert bacterlal density to biovolume. Volumes of $0.52 \mu^{3}$ cell ${ }^{-1}$ for freshwater samples (average diameter of $1.0 \mu \mathrm{m}$ ) and $0.18 \mu^{3} \mathrm{cell}^{-1}$ for marine samples (average diameter of $0.7 \mu \mathrm{m}$ ) were used to convert Ppico density to biovolume. A volume of $22.45 \mu^{3} \mathrm{cell}^{-1}$ (average diameter of $3.5 \mu \mathrm{m}$ ) was used to convert Pnano and fmano density to biovolume.

Live samples were also taken from acid-rinsed Niskin bottles and cultured for bacterivorous protozoa using the Most Probable Number culture technique (MPN) described in Appendix II. This procedure was generally used only with the $1 \mathrm{~m}$ and $100 \mathrm{~m}$ samples of the vertical profiles taken in the North Atlantic. Depths shallower than $100 \mathrm{~m}$ were used for Continental Shelf samples. The MPN technique was performed in Lake Ontario on seven water samples taken on 23-24 August 1982 . 


\section{RESULTS AND DISCUSSION}

Factors Affecting Pico- and Nanoplankton Distributions

The extent of the observed vertical and seasonal fluctuations in picoplankton and nanoplankton in Lake Ontario and the North Atlantic is summarized in Figures 1.2-1.5. All vertical profiles within an environment (Sargasso Sea, Gulf Stream, Continental Shelf/Slope, Lake Ontarlo) were plotted and the maximum range of variation of these profiles is indicated in Figures $1.2-1.5$ by the hatched area. Summed profiles for all the North Atlantic stations are presented in Figure 1.6.

The range of population densities shown in Figures 1.2-1.6 should represent nearly the full extent of the seasonal changes in population densities since the samples were collected during the winter, spring and summer. Changes in the abundance of the $<20 \mu$ plankton in the North Atlantic due to depth were generally as large as, or larger than, changes associated with season. This was expected for phototrophic populations which require sunlight for growth but was also observed for heterotrophic populations. The magnitude of decreases in abundance with depth was not as great for the Lake Ontarlo profiles. This may be a result of the relatively shallow water depth of the Lake.

Season strongly affected the vertical distribution of microorganisms at the Continental Shelf/Slope and Lake Ontario stations. Population densities at these stations during the winter were essentially constant throughout the water column, presumably a result of rapid vertical mixing. The presence of a permanent thermocline at the Sargasso Sea and Gulf Stream stations maintained differences in abundance on a vertical basis throughout the year.

Seasonal changes in the density of pico- and nanoplankton were not quite as large as shifts in population density between the three oceanic environments. The maximum abundances attalned in the Shelf/Slope were 
Figure 1.2. Extent of the seasonal changes in the abundance of pico- and nanoplankton (hatched area) inferred from 12 vertical profiles in the Sargasso Sea. Sampling dates and locations are given in Appendtx VI and Figure 1.1. 


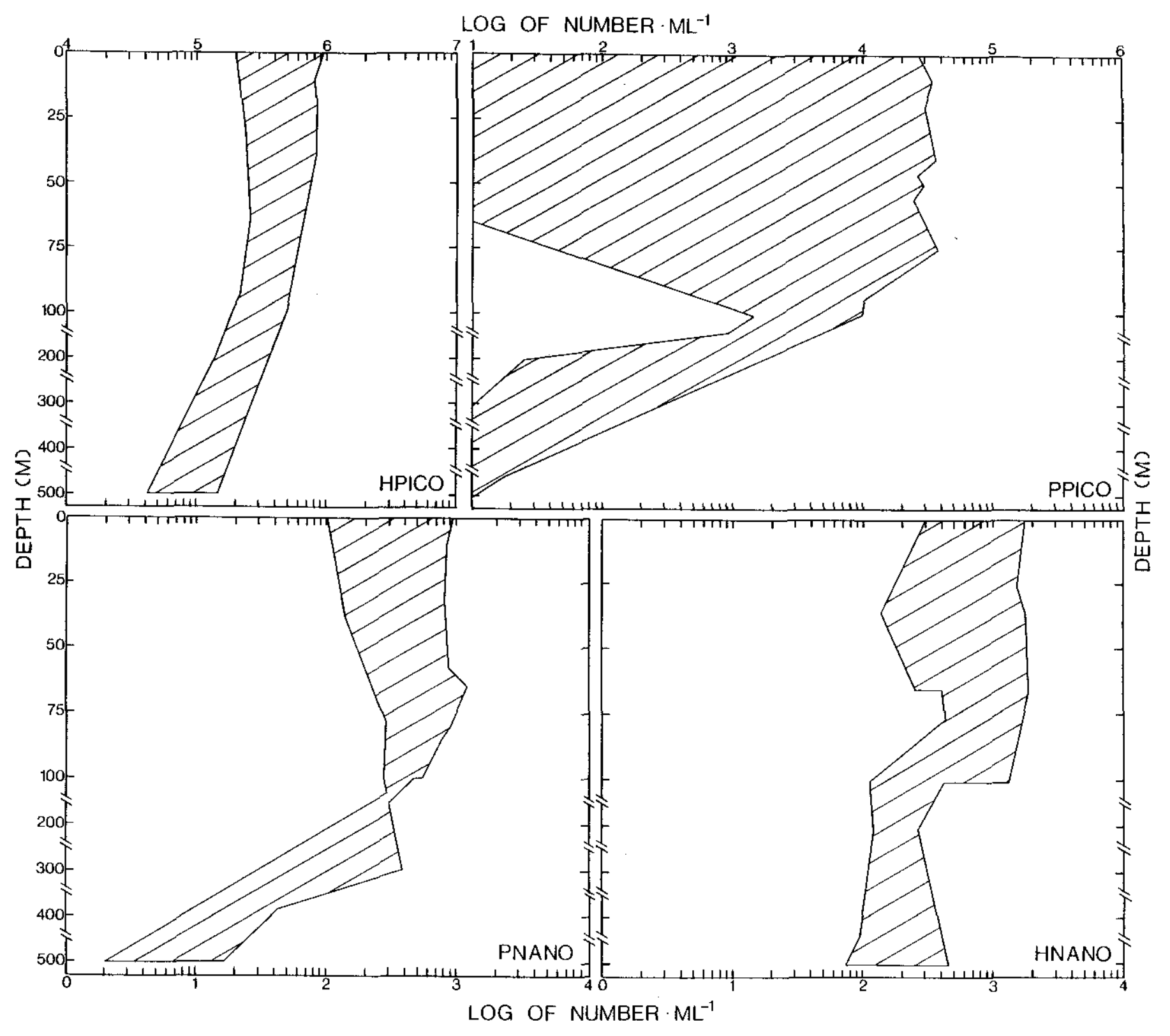


Figure 1.3. Extent of the seasonal changes in the abundance of pico- and nanoplankton (hatched area) inferred from five vertical profiles in the Gulf Stream. Sampling dates and locations are given in Appendix VI and Figure 1.1. 


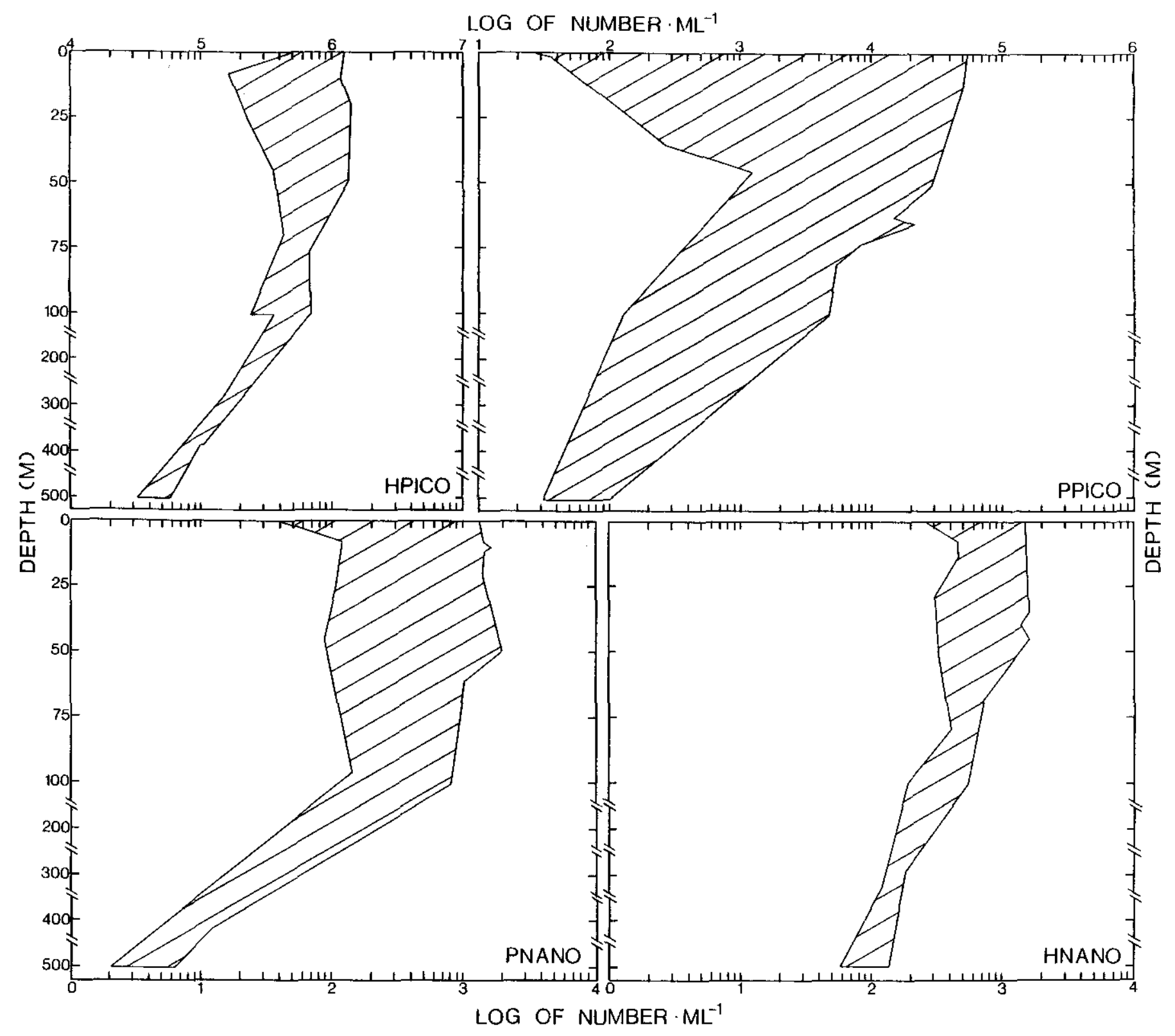


Figure 1.4. Extent of the seasonal changes in the abundance of pico- and nanoplankton (hatched area) Inferred from six vertical profiles in the Continental Shelf/Slope environment. Sampling dates and locations are given in Appendix VI and Figure 1.1. 


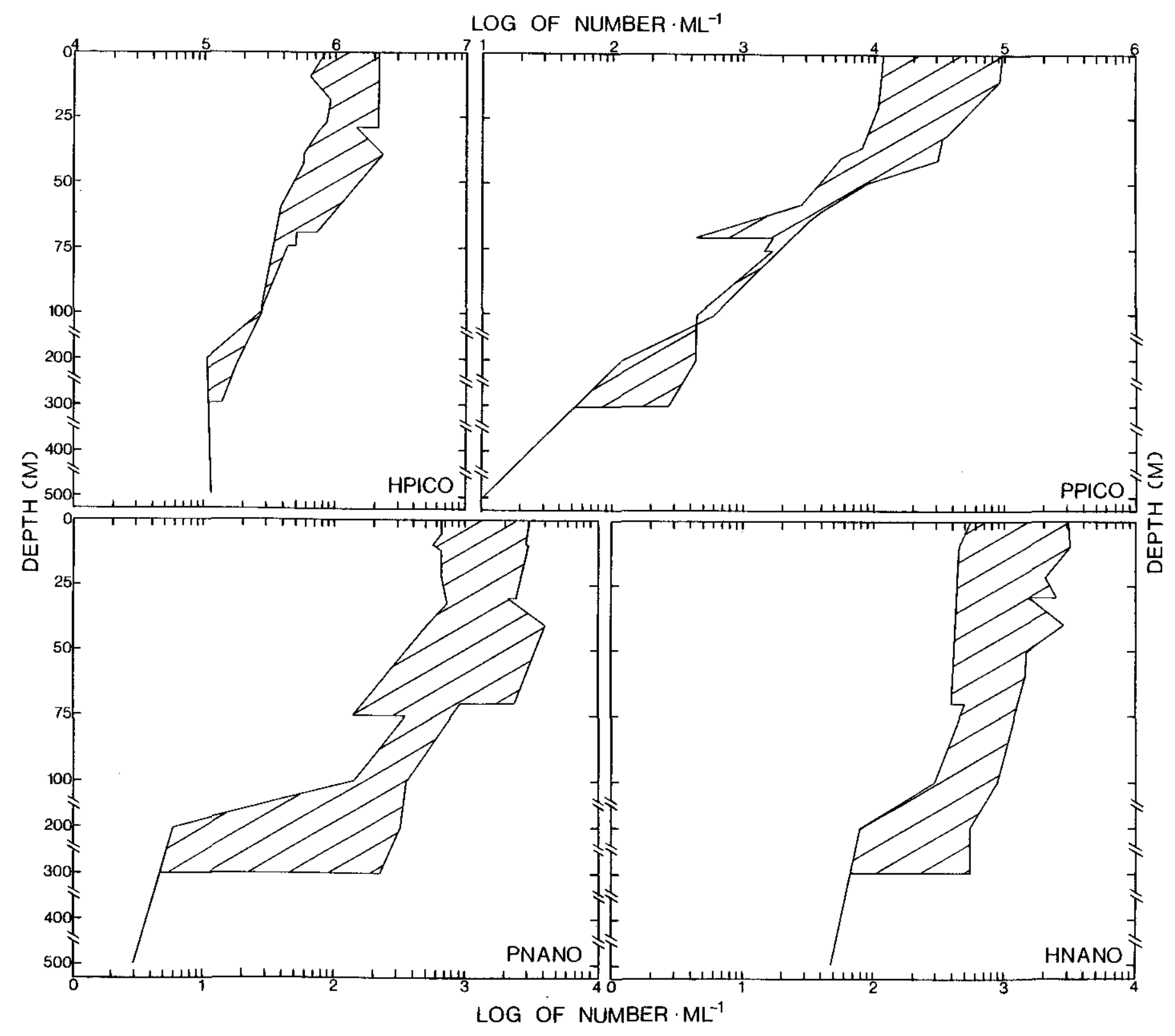


Figure 1.5. Extent of the seasonal changes in the abundance of pico- and nanoplankton (hatched area) inferred from six vertical profiles in Lake Ontario. Sampling datẹ and locations are given in the Methods and Materials. 


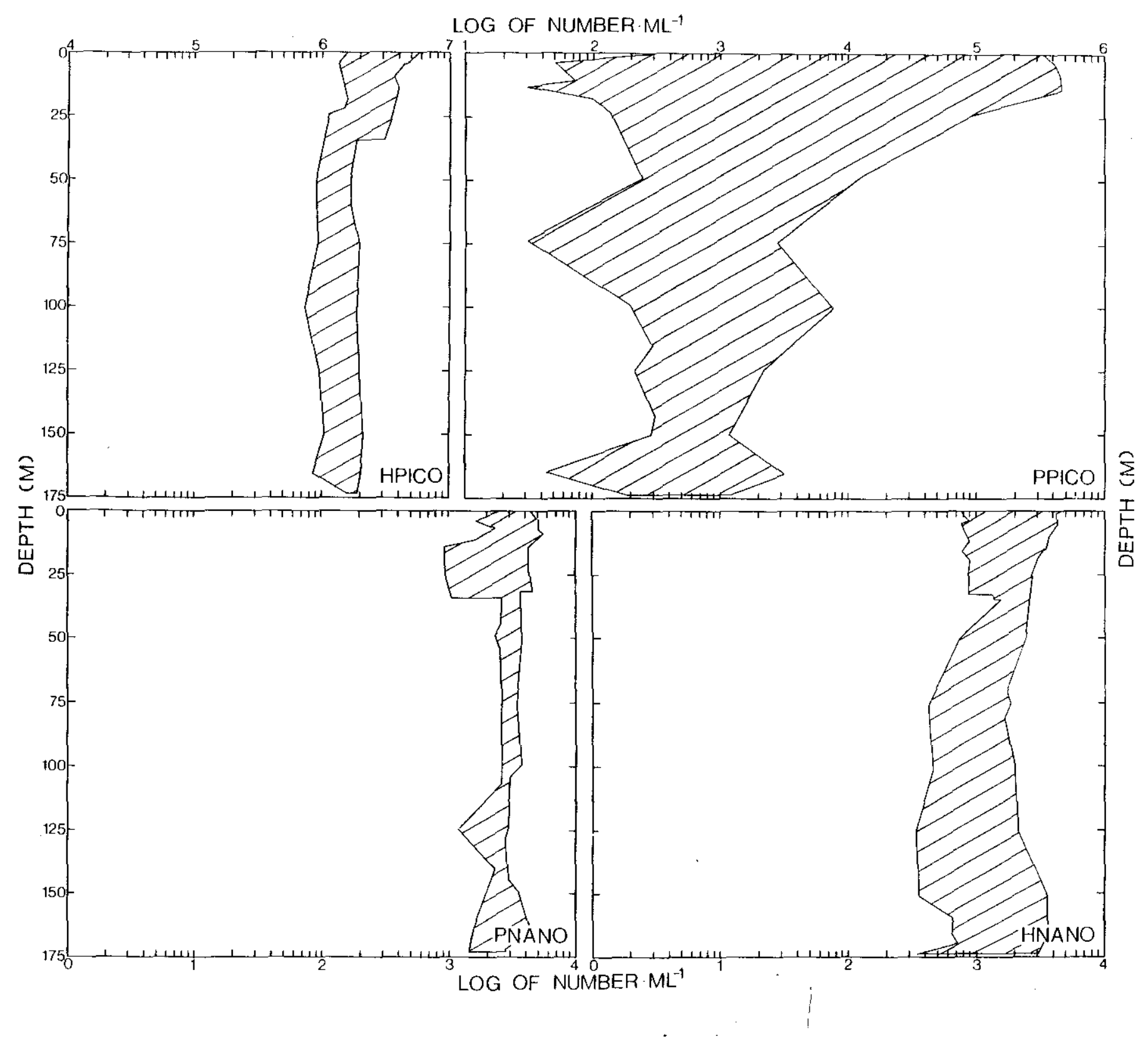


Figure 1.6. Extent of the seasonal changes in the abundance of pico- and nanoplankton (hatched area) in the summed North Atlantic stations (Figures 1.2-1.4) inferred from 23 vertical profiles in the Sargasso Sea, Gulf Stream and Continental Shelf/slope. 


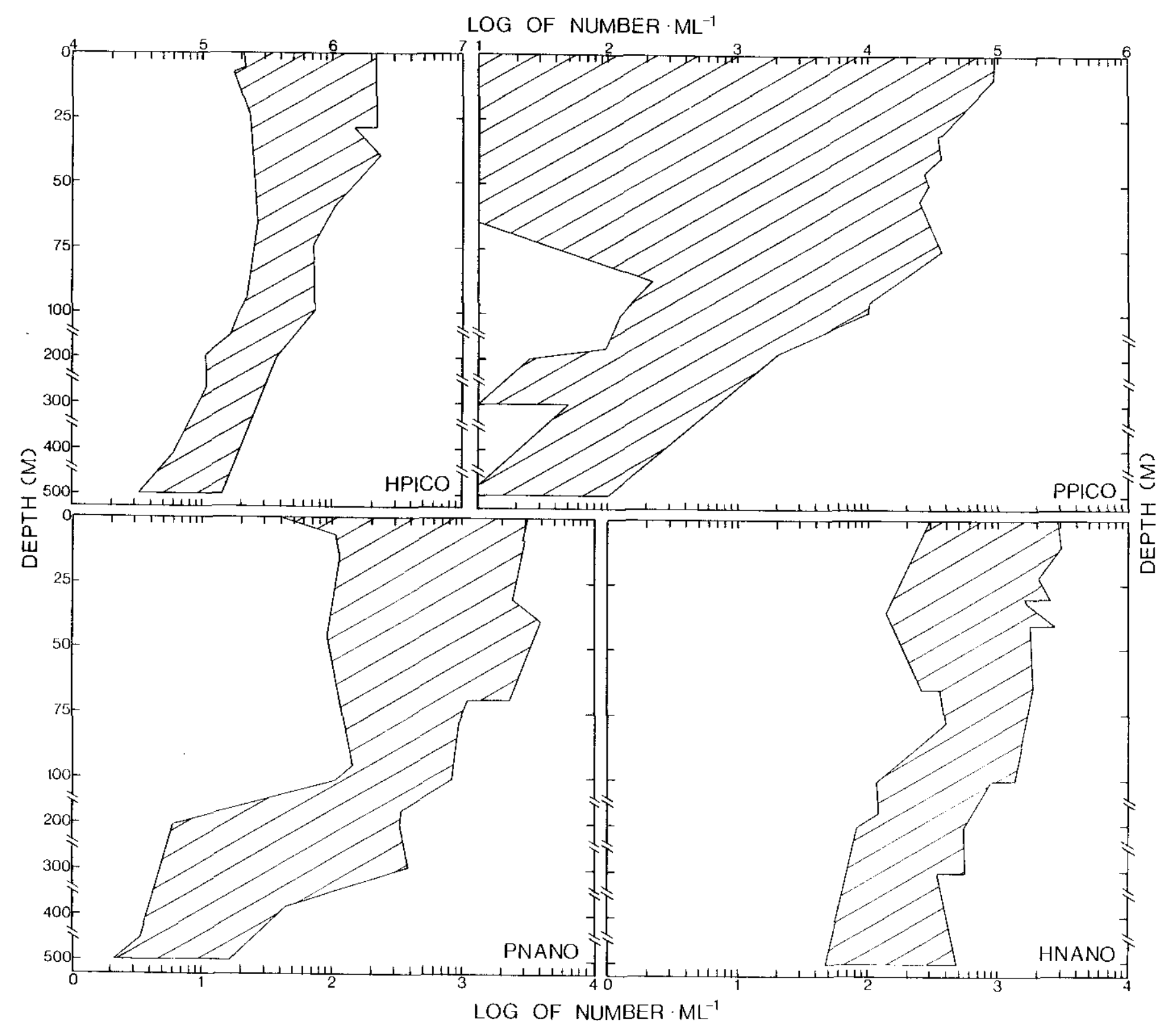


slightly greater than those attained in the open ocean environments. However, there was a large amount of overlap between the three environments. This can be seen by a comparison of the widths of the distributions in Figure 1.6 with those in Figures 1.2-1.4.

Changes in the abundance of individual components of the pico- and nanoplankton varled greatly. Hp1co generally showed a seasonal or spatial (between-station) variation of less than an order of magnitude for any given depth. The largest changes in the density of Hplco occurred along a vertical profile and were correlated with the presence of a thermocline. Stratification of the water resulted in greater Hpico density in surface waters relative to deep waters, presumably due to effective trapping of organic matter in the surface waters and the warmer water temperature at the surface. In contrast to Hplco, Ppico showed seasonal changes in surface waters in excess of three orders of magnitude (Figure 1.5). This variability was also observed in Lake Ontarlo, where it has been correlated with temperature (Caron et al., Appendix V). Phototrophic and heterotrophic nanoplankton denslties showed seasonal changes that were comparable to each other, and generally were intermediate between changes in bacterlal and cyanobacterial density.

Seasonal changes of abundances observed in this study are in agreement with other seasonal studies in these environments. Algal biomass in Lake Ontario has been shown to vary seasonally by approximately one order of magnitude (Munawar et al., 1974; Stadelman \& Munawar,1974). Inano and Ppico have not previously been enumerated in Lake Ontario. The seasonal and spatial range of pico- and nanoplankton abundance observed in the ocean during this study are also in agreement with published data. Densities of Hpico (Ferguson \& Rublee, 1976; Watson, 1977; Ramsay, 1978; Sleburth \& Davis, 1982), Ppico (Waterbury, 1984), Pnano (Davis et al., submitted) and Hnano (Mo1seev, 
1980; Fenchel,1982d; Sfeburth \& Davis, 1982; Caron, 1983; Sherr \& Sherr, 1983; Sherr et al., 1984; Davis et al., submitted) are within the range of densities observed in this study.

The importance of seasonal changes in the abundance of $\mathrm{p}^{1} \mathrm{co}^{-}$and nanoplankton cannot be adequately assessed without some estimation of the fluctuations in their abundances due to other factors. Evidence for an important effect of depth has already been noted for the oceanic profiles. However, changes in abundances due to changes in environment (Sargasso Sea, Gulf Stream, Continental Shelf/Slope) were somewhat greater than seasonal changes in those environments (with the exception of Ppico).

Changes in abundance within a single environment during one season were investigated by comparing vertical profiles of microorganisms taken during a single cruise. The ranges of population density observed in this manner are presented for the Sargasso Sea, Continental Shelf/Slope, and Lake Ontario in Figures 1.7-1.9, respectively. The June data set was chosen for the Lake Ontario stations because surface water temperatures were most dissimilar at the two stations at that time. This difference has been shown to cause a lag in the increase of offshore biomass relative to nearshore blomass (Stadelman \& Munawar, 1974).

A comparison of Figures $1.2,1.4$ and 1.5 to Figures $1.7,1.8$ and 1.9 , respectively, indicates that a good deal of the "seasonal" variability associated with the density of pico- and nanoplankton in these environments cannot be distinguished from spatial vartability within that environment. Statistical analysis of the variability is not appropriate due to differences in the depth of the thermocline, light penetration, sampling depth, etc.. However, the width of the hatched areas in Figures 1.2-1.9 provides an estimate of the varlability of microbial abundance. For the Sargasso Sea samples collected in August (Figure 1.7), between-station varlability 
Figure 1.7. Extent of changes in the abundance of pico- and nanoplankton (hatched area) among vertical profiles taken at nine stations in the Sargasso Sea during $R / V$ Atlantis II cruise $\$ 109: 3$. 


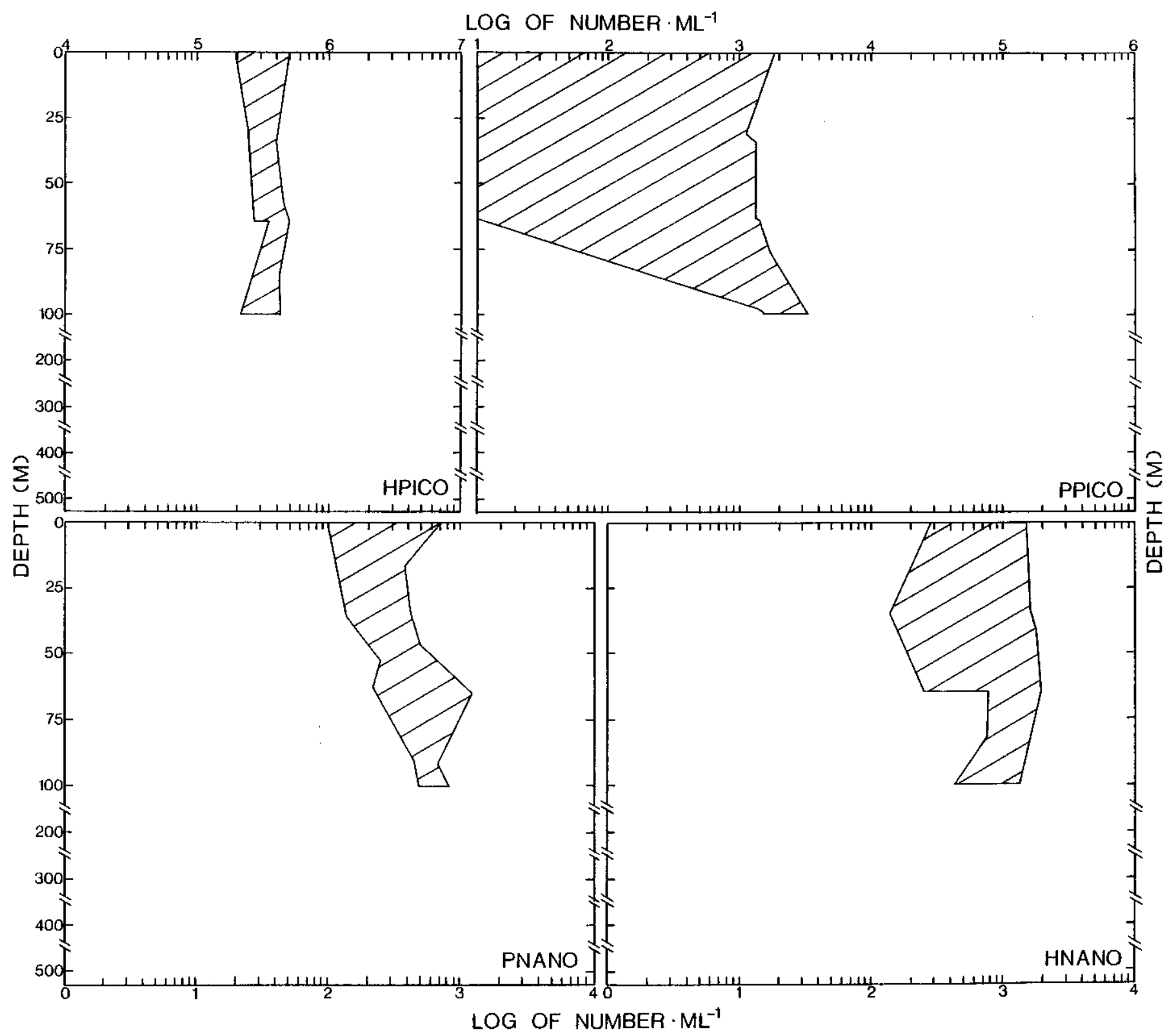


F1gure 1.8. Extent of the changes in the abundance of pico- and nanoplankton (hatched area) among vertical profiles taken at four stations on the Continental Shelf/S1ope during $R / V$ Oceanus cruise \#136. 


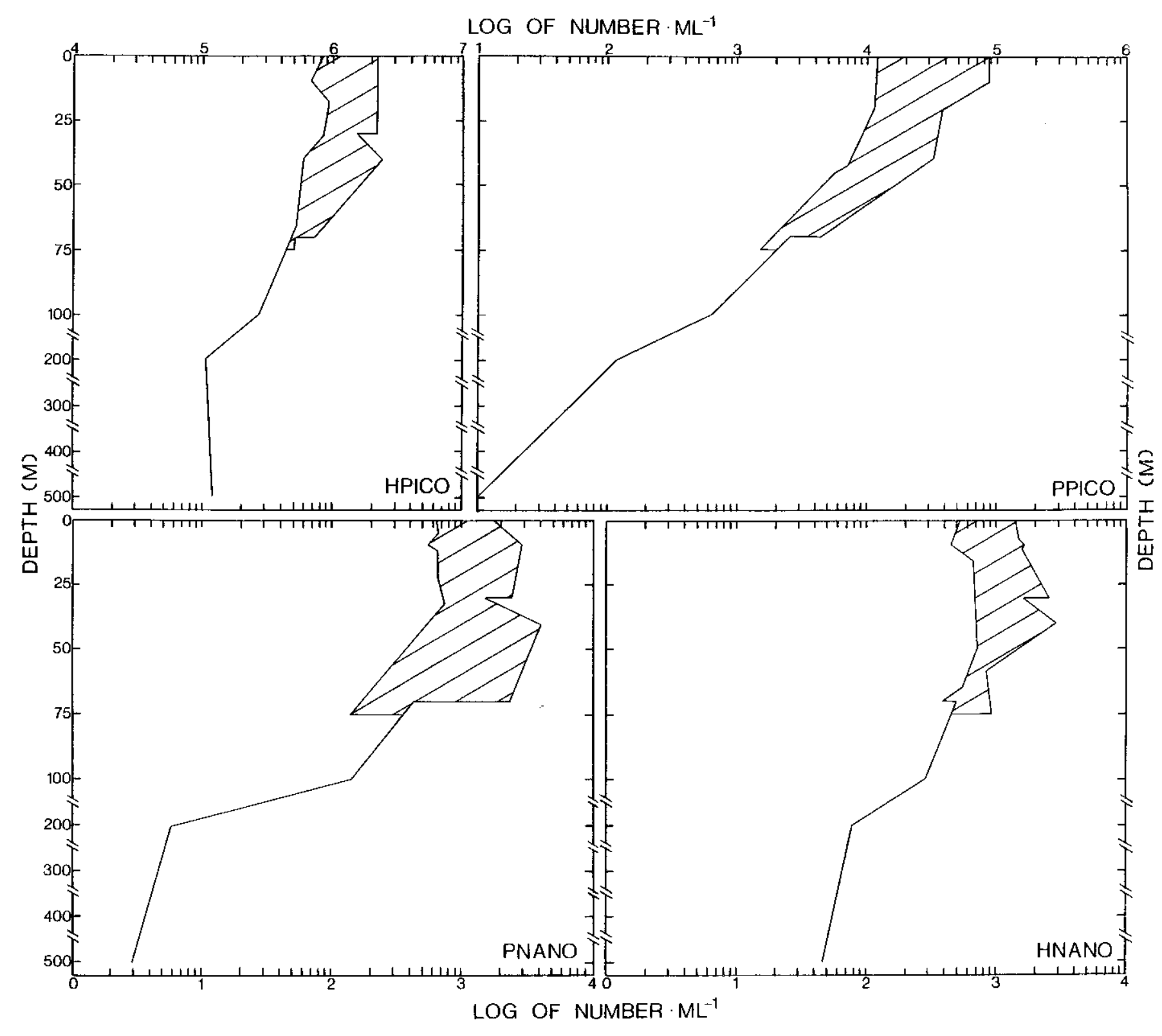


Figure 1.9. Extent of the changes in the abundance of pico- and nanoplankton (hatched area) among vertical profiles taken at the nearshore and offshore stations in Lake Ontario during CSS Limnos cruise $\#^{82-00-016 . ~}$ 


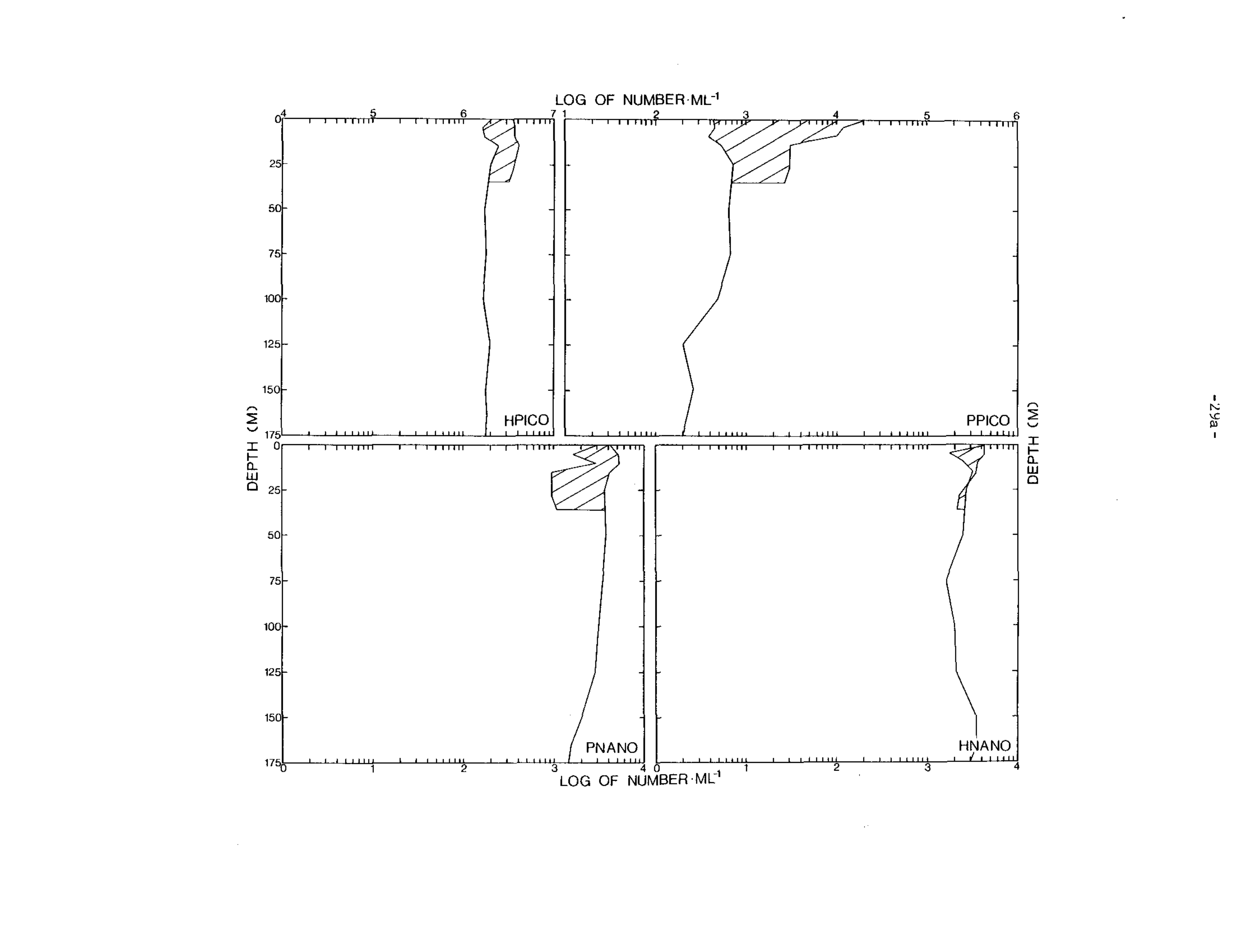


accounted for roughly one-half of the variability in the density of Hpico, Ppico, and Pnano, and virtually all of the varlability in the density of Hnano. For the Continental Shelf/Slope samples collected in August (Figure 1.8), between-station variability accounted for a large portion of the "seasonal" variablitty in the density of all four components in that environment. Between-station variability for Lake Ontario in June (Figure 1.9) accounted for most of the "seasonal" changes in Hpico and Pnano abundance, but less than half of the changes in Ppico and Hnano. It is concluded from these results that small-scale spatial variability within these environments was as important as "seasonal" varlability in these same environments. These results are in agreement with studies which have shown significant fluctuations in Hplco, Pplco, Pnano and Hnano abundance over a diel cycle (Burney et al., 1981; Davis et al., submitted). These studies confirm the highly dynamic nature of pico- and nanoplankton density, and suggest relatively rapid rates of energy and nutrient cycling among these microbial populations. Comparison of Lake Ontario and the North Atlantic

A comparison of the seasonal and spatial distributions of picoplankton and nanoplankton in Lake Ontarlo and the North Atlantic showed fairly strong overlap (Figure 1.10). The double-hatched areas in Figure 1.10 indicate the extent of overlap. Maximum population densities in Lake Ontario generally exceeded maximum population densities observed in the North Atlantic, but significant overlap was apparent. Population ranges of Ppico and finano in Lake Ontario were almost completely encompassed by the North Atlantic ranges. Pnano distributions were the most dissimilar.

Examination of Figures 1.2-1.4 indicates that maximum overlap with the Lake Ontario distributions (Figure 1.5) occurred with the Continental Shelf/Slope environment. This result was not unexpected due to the similarity 
Figure 1.10. Comparison of the seasonal ranges of pico- and nanoplankton density in vertical profiles from the North Atlantic and Lake Ontario. The North Atlantic range was determined from 23 vertical profiles in the Sargasso Sea, Gulf Stream and Continental Shelf/Slope (Figure 1.6). The Lake Ontario range was determined from six vertical profiles at the nearshore and offshore stations (F1gure 1.5). 
LOG OF NUMBER $\cdot \mathrm{ML}^{-1}$

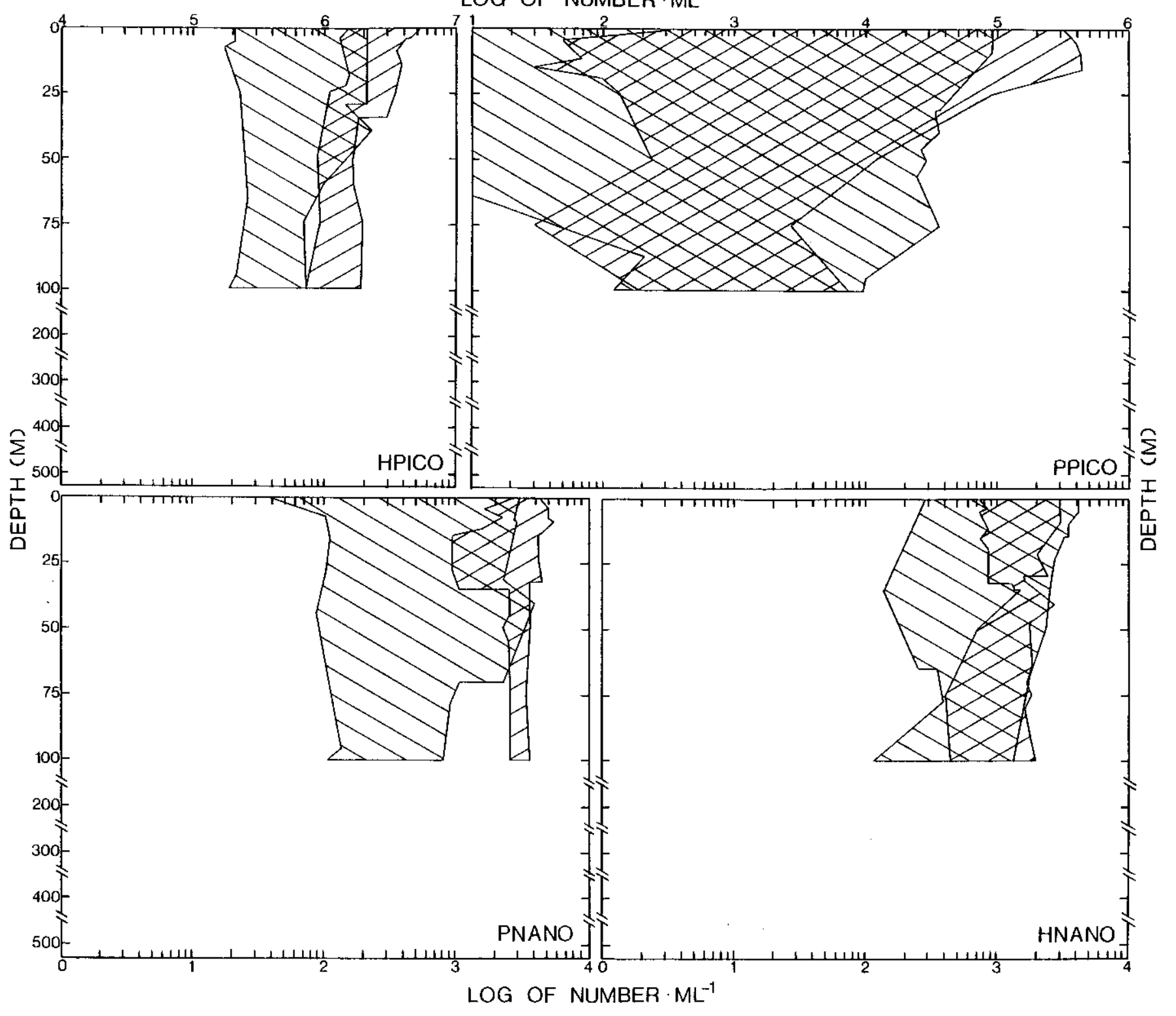


in depth of the water column and primary productivity. Seasonal succession of pico- and nanoplankton in Lake Ontarlo was also closely paralleled by succession in the Shelf/Slope environment. For example, Hpico abundance in surface waters of the Sargasso Sea and Gulf Stream was maximal during the winter while in the Shelf/Slope and Lake Ontario it was maximal during the summer. Likewise, the range of Ppico density in the North Atlantic and Lake Ontario appeared similar, but seasonal succession between open ocean stations (Gulf Stream and Sargasso Sea) and Lake Ontarlo stations was reversed (Figure 1.11). Ppico was maximal during the summer in Lake Ontario (presumably an effect of water temperature), while in the Gulf Stream maximum densitles of Ppico were observed in the winter. Water temperature was relatively warm throughout the year in the latter environment (surface temperature = $20.6-29.5^{\circ} \mathrm{C}$ ) and was probably not as important in determining abundance as it was in Iake Ontario (Caron et al., Appendix V). Nutrient depletion and/or light Inhibition may play a greater role in controlling seasonal changes of Ppico in the open ocean. The development of a strong subsurface maximum in abundance during the summer (Figure 1.11) supports this hypothesis, Large changes in Ppico density were not observed for Shelf/Slope stations in this study. This undoubtedly occurred because the winter profile from this environment was performed in a relatively warm-water area $\left(16.0^{\circ} \mathrm{C}\right)$. Large seasonal changes in Ppico abundance have been observed in temperate environments (Krempin \& Sullivan, 1981; Waterbury et al., 1984). These studies describe seasonal changes which mirror those observed in Lake Ontario both in magnitude and timing.

Examples of the relative contribution of pico- and nanoplankton components In Lake Ontario and the North Atlantic are given in Figure 1.12. This Figure shows the numerical relationships of Hpico, Ppico, Pnano and Hnano in representative vertical profiles from the Sargasso Sea, the Shelf/Slope and 
Figure 1.11. Vertical distribution of Ppico in the Gulf Stream and Lake Ontario at three times of year.

(A) Winter

(D) Spring

(C) Summer 


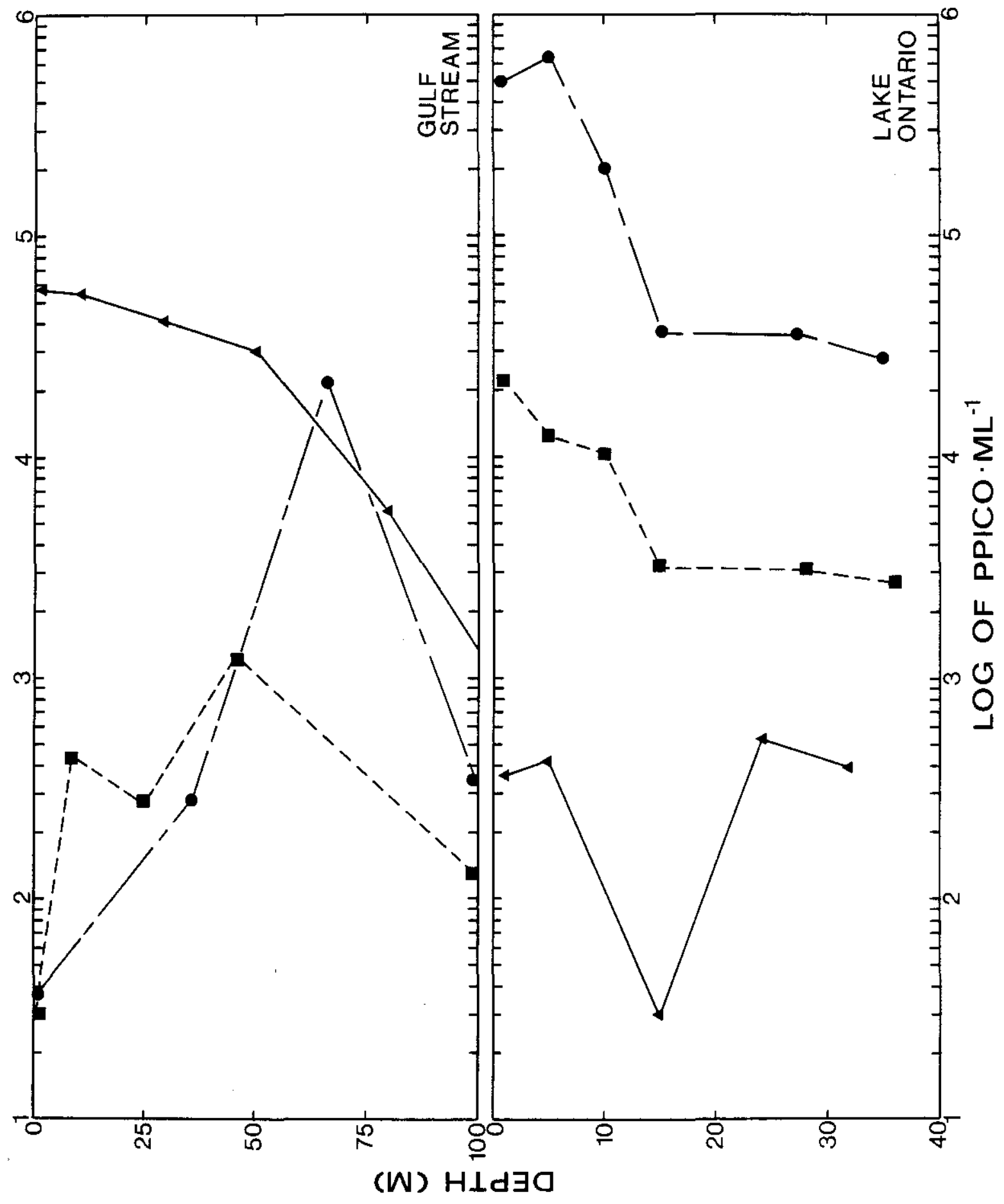


Figure 1.12. Numerical relationships of Hplco, Ppico, Pnano and fnano in representative vertical profiles from the Sargasso Sea $\left(33^{\circ} 59^{\prime} \mathrm{N}, 73^{\circ} 11^{\prime} \mathrm{W}\right.$ on 23 April 1982, Continental Shelf $\left(41^{\circ} 22^{\prime} \mathrm{N}, 69^{\circ} 17^{\prime} \mathrm{W}\right.$ on 12 August 1983) and Lake Ontario (offshore station, 24 August 1982).
(A) Pnano
(P) Inano
(J) Ppico
(D) Hpico 


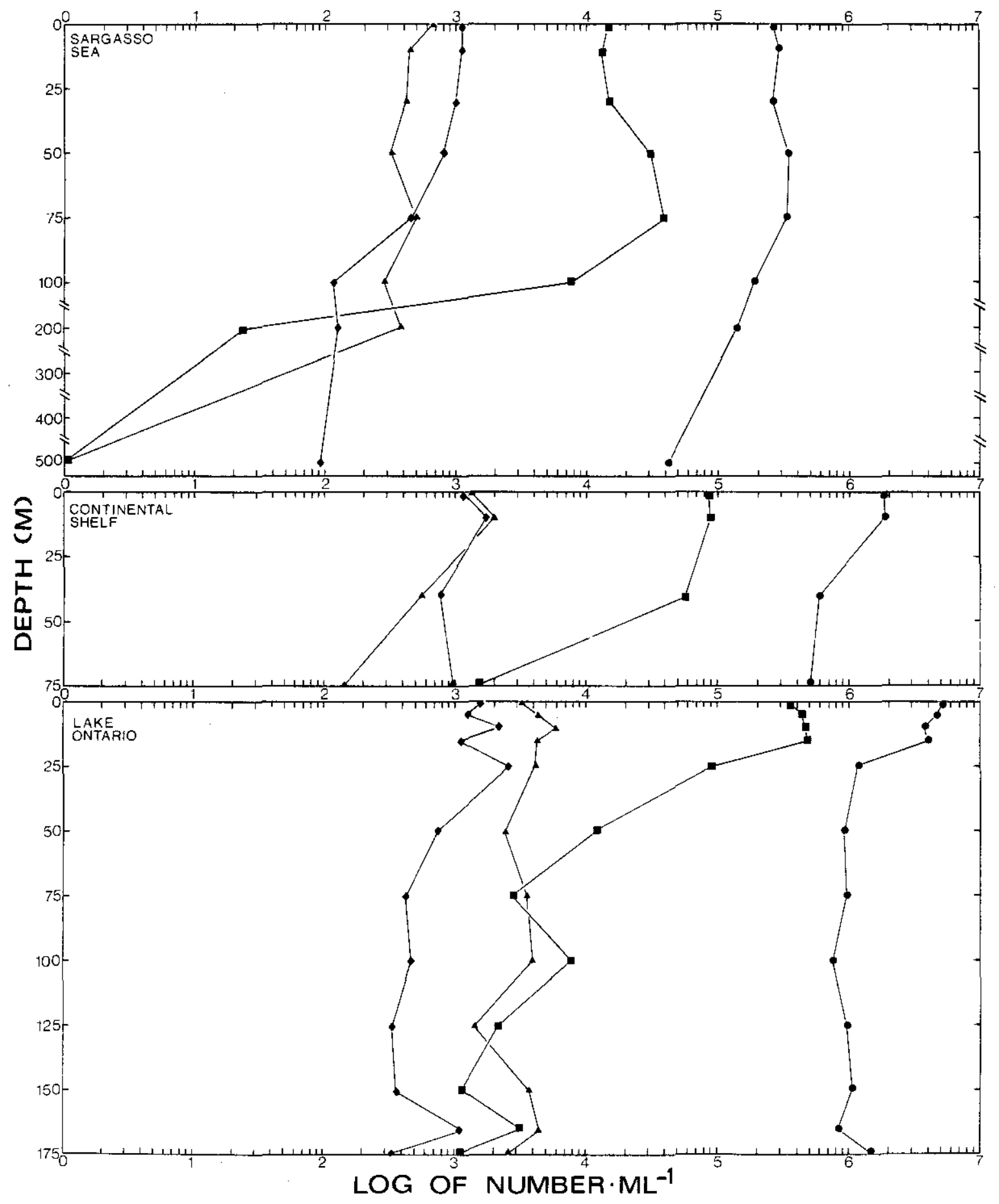


Lake Ontario environments. An increase in the absolute abundance of each of the four populations is obvious in the direction Sargasso Sea < Shelf/slope < Lake Ontario. However, the relative abundances of the populations were nearly unchanged in all three environments. This observation suggests that the marine and freshwater environments may be quite analogous in structure (at this level of observation), but simply differ in their state of eutrophication. This point is shown in Figure 1.13 which shows the average densities of all four populations in the photic zone of each environment. Densities increased in the order Sargasso Sea < Gulf Stream < Shelf/Slope Lake Ontario, but relatively constant proportions of Hpico, Ppico and Pnano were found in all environments. Average Hnano density was more varlable, but still showed an increasing trend in the same direction as the other populations. Relative Contribution of Heterotrophic Microflagellates

Examples of the numerical importance of heterotrophic microflagellates relative to other pico- and nanoplankton populations in Lake Ontario and the North Atlantic has been given in Figure 1.12 and can be inferred from the seasonal/vertical distributions in Figures 1.2-1.5. Population densities were always within an order of magnitude of Pnano densities in marine and freshwater samples in surface waters, and approximately three orders of magnitude less abundant than Hpico. Their relationship to Ppico was highly variable due to the large seasonal changes in Ppico abundance. The numerical relationship of Hnano to other pico- and nanoplankton components is given for all four environments during the three sampling seasons in Figure 1.14. Once again the analogy between the North Atlantic and Lake Ontario communities is apparent. The ratio of Hplco to Hnano followed simllar trends for all four environments. All ratios decreased in magnitude from winter to spring and then increased from spring to summer. Hpico:Hnano ratios during the summer 
Figure 1.13. Average population densities of pico- and nanoplankton in photic waters of the North Atlantic and Lake Ontario. " $n$ " equals the number of samples on which the averages are based.

(a) Pnano

(D) Hnano

(

(A) Hpico 


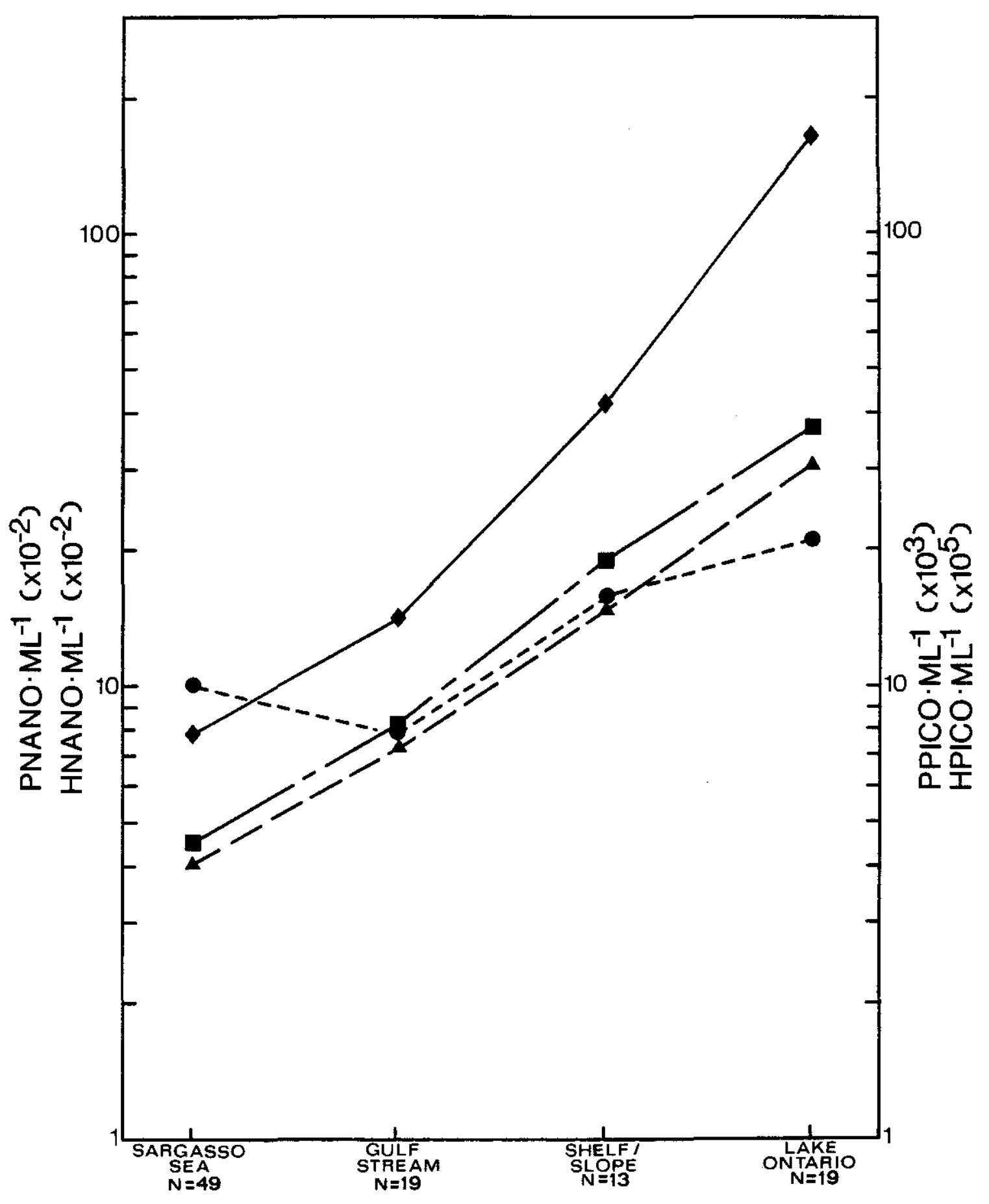


Figure 1.14. Numerical relationship of Hnano to other components of the pico- and nanoplankton in four hydrographic regimes during three seasons. Ratios were based on photic zone samples only. (A) Pnano:Hnano. (B) Hpico:Hnano. (C) Ppico:Hnano.

(D) Sargasso Sea

(A) Gulf Stream

( 7$)$ Shelf/slope

(4) Iake Ontario 

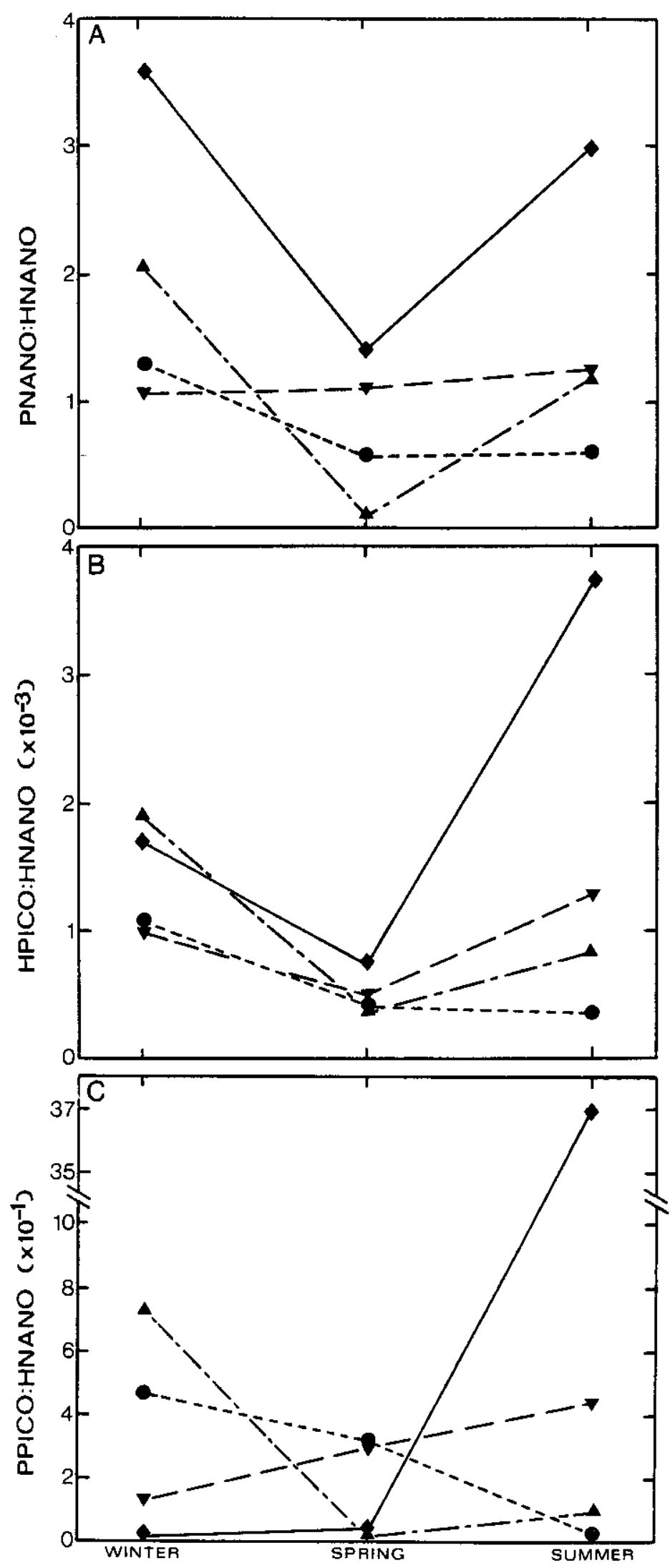
Increased along an environmental gradient (oligotrophic to eutrophic). The largest ratios were associated with Lake Ontario and She1f/S1ope. This trend is the opposite of that observed by Davis \& Sleburth (1982) and Davis et al. (submitted). However, the latter study noted a lack of correlation when all the data were pooled. It is probable that inter-seasonal variations in the ratio of Hpico to Hnano may obscure or even alter relationships which may be present when data from one season are examined. A predator-prey relationship between Hnano and Hpico may also cause rapld changes in the ratio of Hplco to Hnano. Sherr et a1. (1984) observed a constant relationship between Hpico and Hnano, but Fenchel (1982d) noted that the densities of Hpico and Hnano were correlated but were temporally shifted, suggesting a predator-prey relationship between the two populations. Grazing of Hnano on Hpico may explain much of the varlability in Hpico:fnano in this and other studies. However, the magnitudes of the Hpico to Hnano ratios observed in this study were comparable to ratios calculated in other studies (Lighthart, 1969; Fenche1, 1975; Sherr et al., 1984; Davis et al., submitted).

The ratio of Ppico to Hnano exemplifies the similarity of the Shelf/slope and Lake Ontario communities. Ppico:Hnano decreased for the Sargasso Sea and Gulf Stream samples from winter to summer. In contrast, this ratio increased in the She1f/Slope and Lake Ontario communities from winter to summer. This trend has been discussed (Figure 1.11).

Changes in the ratio of Pnano to Hnano for Lake Ontarlo were most similar to changes observed in this ratio for the Gulf Stream. This ratio was always greater for Lake Ontario than for any of the marine environments, and is undoubtedly due to the fact that Pnano distributions in Lake Ontario showed relatively 1ittle overlap with Pnano distributions from the North Atlantic (Figure 1.10). The composition of the Pnano in Lake Ontario was apparently quite different from the North Atlantic population. Pnano density in the Lake 
showed relatively small decreases with depth, even when a well-developed thermocline was present. This can be seen by comparing the density of Hnano to other pico- and nanoplankton components in the photic and aphotic zones of Lake Ontario and the North Atlantic (Table 1.1). It was expected that the heterotrophic components of the pico- and nanoplankton would undergo smaller changes in population density between photic and aphotic environments, and that this would be reflected in their abundance relative to fmano. This was apparent in the ratio of Hpico to Hnano. This ratio in the aphotic zone samples was $0.6-1.7 x$ its value in the photic zone samples. In contrast, Ppico:Hnano and Pnáno:Hnano both decreased by 1-2 orders of magnttude from photic to aphotic zone samples. This decrease was due to large decreases in the phototrophic components. The exception to this trend was Pnano: fnano in Lake Ontario. This ratio in the aphotic zone of the Lake was twice that of the ratio in the photic zone. This unexpected result was not observed in July 1981. It may be due to resuspension of Pnano which were transferred to deeper water via sinking or it may represent the resuspension of Pnano which were ingested (but not digested) and transferred to deeper waters in fecal pellets. Another possibility is that Pnano in the aphotic zone during 1982 were feeding phagotrophically and maintaining high densities in the aphotic zone by reproduction. It is possible that Pnano may obtain energy osmotrophically, but recent speculation suggests that this nutritional mode is unlikely for nanoplankton (Sleburth, in press). Phagotrophic activity of Pnano has been proposed in freshwater (K.Porter, pers. comm.) and marine environments (J.McN. Sieburth, pers. comm.). Phagotrophy was apparently not important for the Pnano below the photic zone in the ocean since their density decreased dramatically in the aphotic zone of this environment. Although heterotrophy by Pnano is possible, it should also be noted that the ratio of Pnano to Hnano increased w1th decreasing bottom depth. Therefore, 
Table 1.1. Average relative abundance of heterotrophic nanoplankton to other pico- and nanoplankton components in the photic and aphotic zone of Lake Ontario and the North Atlantic. Numbers in parentheses show the change in the ratios between photic and aphotic environments (given as $\%$ of the ratio in the photic zone. Only those samples whlch showed a well-developed thermocline were used to calculate the ratios.

\begin{tabular}{|c|c|c|c|c|c|c|}
\hline \multirow[b]{2}{*}{ LOCATION } & \multicolumn{2}{|c|}{ HPICO: HNANO } & \multicolumn{2}{|c|}{ PPICO: HNANO } & \multicolumn{2}{|c|}{ PNANO: HNANO } \\
\hline & PHOTIC & APHOTIC & PHOTIC & APHOTIC & PHOTIC & APHOTIC \\
\hline Sargasso Sea & 490 & $\begin{array}{c}800 \\
(168)\end{array}$ & 12 & $\begin{array}{r}0.04 \\
(0.3)\end{array}$ & 0.71 & $\begin{array}{r}0.04 \\
(9.8)\end{array}$ \\
\hline Gulf Stream & 1200 & $\begin{array}{r}760 \\
(64)\end{array}$ & 33 & $\begin{array}{r}0.63 \\
(1.9)\end{array}$ & 1.3 & $\begin{array}{r}0.03 \\
(2.3)\end{array}$ \\
\hline Shelf/Slope & 1100 & $\begin{array}{l}1270 \\
(112)\end{array}$ & 41 & $\begin{array}{r}0.79 \\
(1.9)\end{array}$ & 1.2 & $\begin{array}{l}0.30 \\
(24)\end{array}$ \\
\hline Lake Ontario & 3700 & $\begin{array}{l}2100 \\
(57)\end{array}$ & 370 & $\begin{array}{l}12 \\
(3.2)\end{array}$ & 3.0 & $\begin{array}{c}5.9 \\
(197)\end{array}$ \\
\hline
\end{tabular}


resuspension may be important for explaining the large densities of Pnano in the aphotic zone of Lake Ontario.

The overall seasonal and spatial distribution of Hnano in Lake Ontario showed a great deal of analogy to the distribution in the North Atlantic (Figure 1.10). Lesser minimum densities were observed in the North Atlantic (presumably because of the more oligotrophic conditions in the open ocean). Nevertheless, most of the vertical profiles showed overlapping distributions.

Direct counts by eplfluorescence microscopy offer only one way to estimate the number of heterotrophic microflagellates (see Appendix II for discussion). Most Probable Number (MPN) culture estimates were also performed at selected stations and depths in all four environments. The range and average MPN counts are given in Table 1.2. Microflagellates were the most abundant bactertvorous protozoa cultured in all four environments, and were observed In all samples. Cultured microflagellates were dominated taxonomically by colorless chrysomonads such as Paraphysomonas (Hibberd, 1979). Bodontd flagellates were also abundant. Davis (1982) has described the taxonomic composition of heterotrophic microflagellates in the North Atlantic. Amoebae were second in abundance and in the total number of samples showing growth of protozoa. These protozoa were domfnated taxonomically by Acanthamoeba (Davis et al., 1978). Bacterivorous clliates were rarely observed In the open ocean ( 1 positive sample out of 40 Sargasso Sea and 11 Gulf Stream samples). Increasing densities of microflagellates were observed on an offshore-to-inshore transect in the North Atlant1c. Densitles of protozoa in Lake Ontario averaged more than an order of magnitude greater than densities In the North Atlantic. Similar results were observed for the amoebae and ciliates. It is proposed that these four environments represent an environmental gradient, with the Sargasso Sea and Gulf Stream at one end of the gradient, Lake Ontario at the other end, and the Shelf/Slope 
Table 1.2. Most Probable Number estimates of the bacterivorous protozoa in samples obtained in acid-rinsed Niskin bottles from the North Atlantic and Lake Ontario. A range and mean density are given. Numbers in parentheses indicate the number of samples which showed growth of protozoa. The means $(\bar{X})$ given in the Table include only those samples which showed positive growth.

\begin{tabular}{|c|c|c|c|c|}
\hline \multirow[b]{2}{*}{ LOCATION } & \multirow[b]{2}{*}{$\begin{array}{l}\text { NO. OF } \\
\text { SAMPLES }\end{array}$} & \multicolumn{3}{|c|}{ MPN per $100 \mathrm{MI}$} \\
\hline & & CILIATES & FLAGELLATES & AMOEBAE \\
\hline SARGASSO SEA & 40 & $\begin{array}{c}N D^{*}-1.01 \\
\overline{\mathrm{X}}=1.01 \quad(1)\end{array}$ & $\begin{array}{c}0.81-590 \\
\bar{x}=59.7(40)\end{array}$ & $\begin{array}{l}N D-3.03 \\
\overline{\mathrm{X}}=0.78 \quad(18)\end{array}$ \\
\hline GULF STREAM & 11 & $\begin{array}{l}\text { ND } \\
-\end{array}$ & $\begin{array}{c}8.6-309 \\
\bar{x}=58.5(11)\end{array}$ & $\begin{array}{l}N D-3.0 \\
\bar{x}=1.71 \quad(7)\end{array}$ \\
\hline SHELF/SLOPE & 9 & $\begin{array}{l}N D-0.37 \\
\bar{X}=0.37 \quad(2)\end{array}$ & $\begin{array}{l}17.3-879 \\
\bar{x}=186 \quad(9)\end{array}$ & $\begin{array}{l}0.37-85.9 \\
\overline{\mathrm{X}}=10.3(9)\end{array}$ \\
\hline $\begin{array}{l}\text { NORTH ATLANTIC } \\
\text { (TOTAL) }\end{array}$ & 60 & $\begin{array}{l}\mathrm{ND}-1.01 \\
\overline{\mathrm{X}}=0.58 \quad(3)\end{array}$ & $\begin{array}{c}0.81-879 \\
\bar{X}=72.1 \quad(60)\end{array}$ & $\begin{array}{c}N D-85.9 \\
\bar{X}=3.49(34)\end{array}$ \\
\hline LAKE ONTARIO & 7 & $\begin{array}{c}N D-17.3 \\
\bar{X}=10.4 \quad(6)\end{array}$ & $\begin{array}{l}84-10,500 \\
\bar{X}=2,400 \quad(7)\end{array}$ & $\begin{array}{l}\mathrm{ND}-173 \\
\overline{\mathrm{X}}=30.2(6)\end{array}$ \\
\hline
\end{tabular}

* ND indicates that no positive cultures were obtained at the lowest dilution. (Theoretical limtt of detection $=0.37$ organisms per $100 \mathrm{ml}$. ) 
environment intermediate to these extremes. The MPN estimates (Table 1.2) and the average population densities given in Figure 1.13 suggest that the picoplankton and nanoplankton of Lake Ontario represent a microbial plankton community which is analogous to marine plankton communities, but one which is more eutrophic than the marine communties examined in this study.

The observed changes in the number of heterotrophic microflagellates between the four environments as estimated by the MPN technique (Table 1.2) were greater than changes in this population suggested by the epifluorescence counts (FIgures $1.10 \mathrm{~d} \& 1.13$ ). This Indicates that the ratio of the density of heterotrophic microflagellates determined by the MPN technique to that determined by the epifluorescence technique must be different between the environments (Table 1.3). The possible significance of a change in this ratio is discussed in Appendix II. Briefly, a change in this ratio may indicate a change in the relative contribution of non-microflagellate entities to the direct counts, a difference in the trophic mode of the microflagellates composing the population (e.g. herblvorous to bacterivorous), or a difference in the physlological state of the microflagellates in the population which in turn affects culture success. Since the ratio changed along an oligotrophic-to-eutrophic gradient it is suggested that the latter two explanations may explain this observation.

The relative importance of picoplankton (potential prey for microflagellates) in these environments may explain the large varlability in the number of culturable microflagellates. Blovolumes calculated from the abundances given in Figure 1.12 are presented in Figure 1.15. Wide numerical disparity between the four populations is greatly reduced by conversion to blovolume. While densities of the four populations in surface waters collectively span more than three orders of magnitude, their corresponding biovolumes differed by only one order of magnitude. The relative importance 
Table 1.3. Comparison of the Most Probable Number estimates (MPN) of flagellated protozoa and epifluorescence counts (DC) of heterotrophic nanoplankton (expressed as the percent of the direct counts accounted for by the MPN estimates).

\begin{tabular}{|c|c|c|}
\hline LOCATION & $\begin{array}{l}\text { NO. OF } \\
\text { SAMPLES }\end{array}$ & MPNx100:DC \\
\hline SARGASSO SEA & 40 & $\begin{array}{c}<0.01-0.70 \\
\overline{\bar{x}}=0.09\end{array}$ \\
\hline GULF STREAM & 11 & $\begin{array}{c}0.02-0.45 \\
\bar{X}=0.10\end{array}$ \\
\hline SHELF/SLOPE & 9 & $\begin{array}{r}0.01-1.6 \\
\bar{X}=0.44\end{array}$ \\
\hline IAKE ONTARIO & 8 & $\begin{array}{c}0.08-6.8 \\
\bar{X}=1.9\end{array}$ \\
\hline
\end{tabular}


Figure 1.15. Biovolumes of Hpico, Ppico, Pnano and Hnano in representative vertical profiles from the Sargasso Sea, Continental Shelf and Lake Ontario. See Figure 1.12 for station locations and dates.
(A) Pnano
( ) Hnano
(I) Pplco
(อ) Hpico 


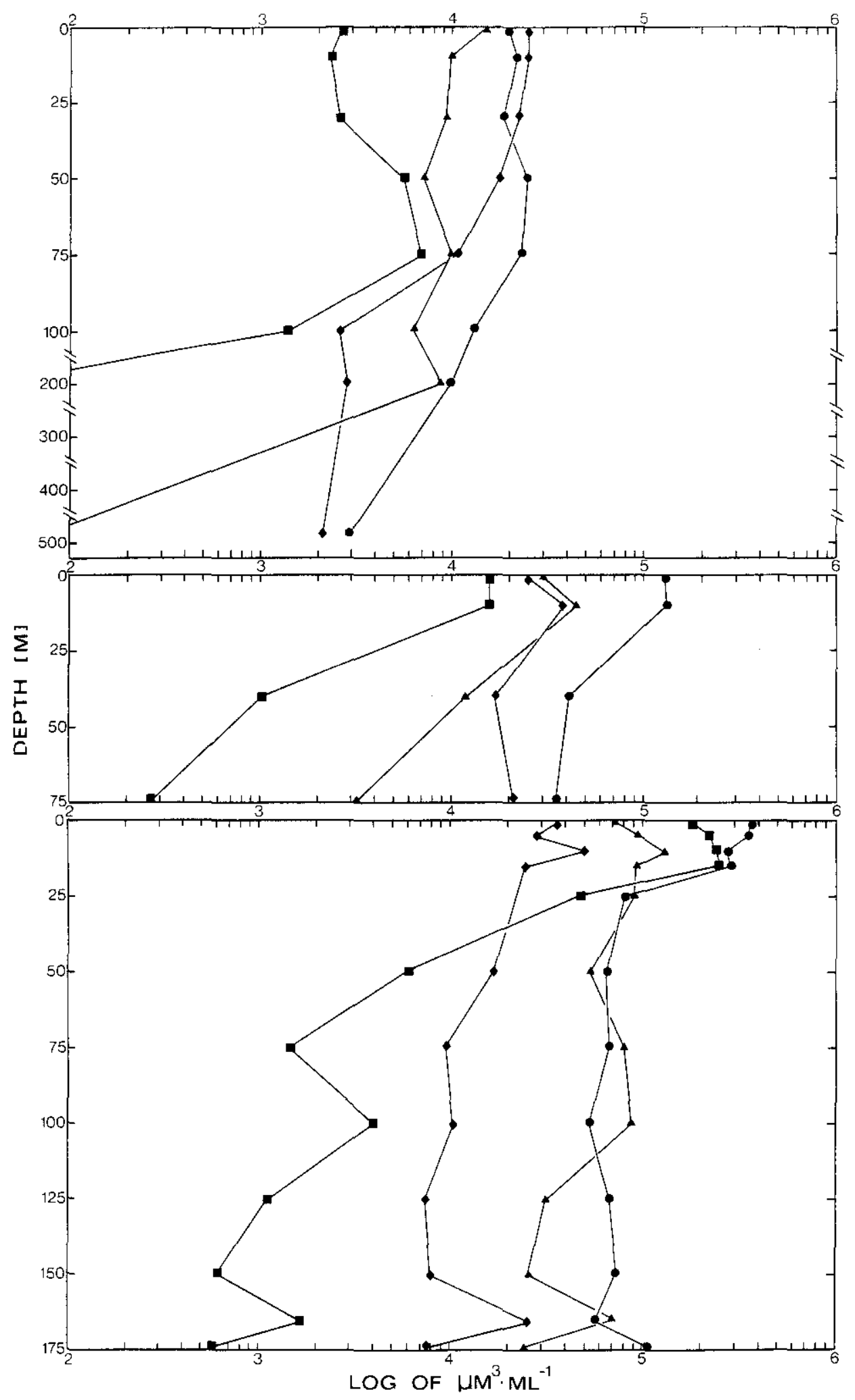


of picoplankton biovolume is in the direction Lake Ontario > Shelf/Slope > Sargasso Sea \& Gulf Stream. This is also the direction of the increase in the ratio of MPN to epifluorescence counts (Table 1.3). Thus, it seems probable that the increased biomass of picoplankton prey may be responsible for a shift In the composition of heterotrophic nanoplankton towards bacterivorous forms. Discrepancies between MPN and direct counting techniques have been noted previously. Davis et al. (submitted) noted large discrepancles between MPN estimates and direct counts for oceanic samples (MPN:DC approximately $0.1 \%$ ) and a decrease in the magnitude of the discrepancy for estuarine samples (MPN:DC approximately 0.1-26\%). Fenche1 (1982d) found relatively close agreement between MPN estimates and direct counts in a nearshore eutrophic marine environment. MPN estimates of the number of bacterivorous microflagellates in macroscopic detrital aggregates accounted for as much as $51.7 \%$ of the direct counts (Chapter 2 ). These results suggest that changes in the trophic mode of the fnano may account for the increase in the percent of this population which can be cultured. However, the possibility that offshore species are more fastidious in their cultural requirements cannot yet be ruled out as an explanation for the discrepancles between the two techniques. Concluston

Similarity in the relative abundance of phototrophic and heterotrophic components of the pico- and nanoplankton (Figure 1.10) suggest that the $<20$ um plankton of Lake Ontario is highly analogous to the plankton of the North Atlantic. Maximum abundances of pico- and nanoplankton in Lake Ontario exceeded maximum abundances of these populations in the marine environments examined in this study, but are in agreement with population densities observed in eutrophic marine environments (Vinogradov et a1., 1976; Tumantseva \& Sorokin, 1977; Sorok1n \& Kogelschatz, 1979; Sorokin, 1981; Tumantseva, 1981). The plankton $>20 \mu \mathrm{m}$ differs dramatically between the North 
Atlantic and Lake Ontario. Aside from the obvious differences in species composition for taxa which are found in both environments (e.g. copepods) there are also dramatic differences in the composition of the zooplankton taxa from the two environments. Rotifers are a conspicuous component of the Lake Ontario plankton, but are rare in the oceanic plankton. Conversely, marine plankton communities include several taxa (e.g. tunicates) which are absent from freshwater environments. Despite the fact that grazing by these zooplankton is capable of significantly altering pico- and nanoplankton density, their effects are not apparent as significant shifts in the relative abundance of Hplco, Pplco, Pnano and Hnano. If dissimilarities are Indeed present in the $<20$ um plankton of these marine and freshwater environments, they apparently do not manifest themselves as severe shifts in the relative or absolute abundances of the four populations enumerated in this study. 


\section{REFERENCES}

Azam, F., T. Fenchel, J.G. Field, J.S. Gray, L.A. Meyer-Reil \& F. Thingstad. 1983. The ecological role of water-column microbes in the sea. Mar. Ecol. Prog. Ser. 10: 257-263.

Beers, J.R., F.M.H. Reld \& G.L. Stewart. 1975. Microplankton of the North Pacific Central Gyre. Population structure and abundance, June, 1973. Int. Revue ges. Hydrobiol. 60: 607-638.

Beers, J.R., F.M.H. Reid \& G.L. Stewart. 1982. Seasonal abundance of the microplankton population in the North Pacific central gyre. Deep-Sea Res. 29: 227-245.

Booth, B.C., J. Lewin \& R.E. Norris. 1982. Nanoplankton specles predominant in the subarctic Pacific in May and June 1978. Deep-Sea Res. $29: 185-200$.

Broke1, K. von. 1981. The importance of nanoplankton within the pelagic Antarct1c ecosystem. Kieler Meeresforsch. 5: 61-67.

Burney, C.M., P.G. Davis, K.M. Johnson \& J.McN. Sieburth. 1981. Dependence of dissolved carbohydrate concentrations upon small scale nanoplankton and bacterioplankton distributions in the Western Sargasso Sea. Mar. B1o1. 65: 289-296.

Caron, D.A. 1983. Technique for enumeration of heterotrophic and phototrophic nanoplankton using epifluorescence microscopy, and comparison with other procedures. App1. Environ. Microblo1. 46: 491-498. Davis, P.G. 1982. Bacterivorous flagellates in marlne waters. Ph.D. Thesis, University of Rhode Island. 218pp.

Davis, P.G., D.A. Caron, P.W. Johnson \& J.McN. Sieburth. Submitted. Geographic, seasonal and diel distribution of phototrophic and heterotrophic components of the picoplankton and nanoplankton in the North Atlantic. Mar. Ecol. Prog. Ser. 
Davis, P.G., D.A. Caron \& J.McN. Sleburth. 1978. Oceanic amoebae from the North Atlantic: Culture, distribution and taxonomy. Trans. Amer. Micros. Soc. 97: 73-88.

Davis, P.G. \& J.McN. Sieburth. 1982. Differentiation of the photosynthetic and heterotrophic populations of nanoplankters by epifluorescence microscopy. Ann. Inst. oceanogr., Paris 58(S): 249-259.

Fenchel, T. 1975. The quantitative importance of the benthic microfauna of an Arctic Tundra Pond. Hydroblologia 46: 445-464.

Fenchel, T. 1982a. Ecology of heterotrophic microflagellates. I. Some important forms and their functlonal morphology. Mar. Ecol. Progr. Ser. 8: 211-223.

Fenchel, T. 1982d. Ecology of heterotrophic microflagellates. IV. Quantitative occurrence and Importance as bacterial consumers. Mar. Eco1. Prog. Ser. 9: 35-42.

Ferguson, R.L. \& P. Rublee. 1976. Contribution of bacterla to standing crop of coastal plankton. Limnol. Oceanogr. 21: 141-145.

Glibert, P.M. 1982. Reglonal studies of dally, seasonal and size fraction varlability in ammonfum remineralization. Mar. B1ol. 70: 209-222.

Haas, L.W. 1982. Improved epifluorescence microscopy for observing planktonic micro-organisms. Ann. Inst. oceanogr., Paris 58(S): 261-266.

Haas, L.W. \& K.L. Webb. 1979. Nutritional mode of several non-plgmented microflagellates from the York River Estuary, Virginia. J. exp. mar. B1o1. Ecol. 39: 125-134.

Harrison, W.G. 1978. Experimental measurement of nitrogen remineralization In coastal waters. IImnol. Oceanogr. 23: 684-694. Hentschel, E. 1936. Die biologischen Methoden und das blologische 
Beobachtungsmaterial der Meteor Expedition. Wiss. Ergeben. dt. altant. Exped. 'Meteor' 10: 274pp.

Hibberd, D.J. 1979. Notes on the ultrastructure of the genus Paraphysomonas (Chrysophyceae) with spectal reference to $\underline{P}$. bandalensis Takahash1. Arch. Protistenk. 121: 146-154.

Hillard, D.K. 1971. Notes on the occurrence and taxonomy of some planktonic Chrysophytes in an Alaskan lake, with comments on the Genus Bicoeca. Arch. Protistenk. 113: 98-122.

Johnson, P.W. \& J.McN. Sleburth. 1979. Chroococcoid cyanobacterla in the sea: A ubiquitous and diverse phototrophic biomass. Limnol. Oceanogr. 24: 928-935.

Johnson, P.W. \& J.McN. Sieburth. 1982. In situ morphology and occurrence of eucaryotic phototrophs of bacterlal size in the picoplankton of estuarine and oceanic waters. J. Phycol. 18: 318-327.

Krempln, D.W. \& C.W. Sullivan. 1981. The seasonal abundance, vertical distribution, and relative microblal blomass of chroococcold cyanobacteria at a station in southern California coastal waters. Can. J. Microbiol. 27: $1341-1344$.

Laacke, M., A.B. Dahle, K. Eberlein \& K. Rein. 1983. A modelling approach to the interplay of carbohydrate, bacterla and non-pigmented flagellates in a controlled ecosystem experiment with Skeletonema costatum. Mar. Ecol. Prog. Ser. 14: 71-79.

Li, W.K.W., D.V. Subba Rao, W.G. Harrison, J.C. Smith, J.J. Cullen, B. Irwin \& T. Platt. 1983. Autotrophic picoplankton in the troplcal ocean. Sclence 219: 292-295.

Lighthart, B. 1969. Planktonlc and benthic bacterlovorous protozoa at eleven stations in Puget Sound and adjacent Pacific Ocean. J. Fish. Res. Bd. Canada. 26: 299-304. 
Linley, E.A.S., R.C. Newell \& M.I. Lucas. 1983. Quantitative relationsh1ps between phytoplankton, bacterla and heterotrophic microflagellates in shelf waters. Mar. Ecol. Prog. Ser. 12: 77-89.

Moiseev, E.V. 1980. Seasonal vartations of zooflagellates in coastal areas of the Black Sea. Blologiya mor., Akad. Nauk. SSSR. 5: 76-79. Munawar, M. \& I.F. Munawar. 1975. The abundance and significance of phytoflagellates and nannoplankton in the St. Lawrence Great Lakes. 1. Phytoflagellates . Verh. Internat. Verein. Limnol. 19: 705-723.

Munawar, M., P. Stadelmann \& I.F. Munawar. 1974. Phytoplankton biomass, species composition, and primary production at a nearshore and a midlake station of Lake Ontar1o during IGYGL. Proc. 17th Conf. Great Lakes Res. p. $629-652$.

Paasche, E. \& S. Kristiansen. 1982. Ammonium regeneration by mlcrozooplankton in the 0slofford. Mar. Biol. 69: 55-63. Platt, T., D.V.S. Rao. \& B. Irwin. 1983. Photosynthesis of picoplankton in the oligotrophic ocean. Nature 301: 702-704.

Pomeroy, I.R. \& R.E. Johannes. 1968. Occurrence and respiration of ultraplankton in the upper 500 meters of the ocean. Deep-Sea Res. 15: $381-391$.

Porter, K.G. \& Y.S. Felg. 1980. The use of DAPI for identifying and counting aquatic microflora. LImno1. Oceangr. 25: 943-948.

Ramsay, A.J. 1978. Direct counts of bacterla by a modifled acridine orange method in relation to their heterotrophic activity. N. Z. J. Mar. Freshwater Res. 12: 265-269.

Sherr, B. \& E. Sherr. 1983. Enumeration of heterotrophic microprotozoa by ep1fluorescence microscopy. Est. Coast. Shelf Sc1. 16: 1-7.

Sherr, B.F., E.B. Sherr \& T. Berman. 1983. Grazlng, growth and ammonium excretion rates of a heterotrophic microflagellate fed with four species 
- of bacteria. Appl. Environ. Microbiol. 45: 1196-1201.

Sherr, B.F., E.B. Sherr \& S.Y. Newe11. 1984. Abundance and productivity of heterotrophic nanoplankton in Georgla coastal waters. J. Plankton Res. 6: 195-202.

Sieburth, J.McN. In press. Protozoan bacterivory in pelagic marine waters. In: Hobbie, J.E. \& P.J. 1eB. Willlams (eds.), Heterotrophic act1vity in the sea. Plenum Press, New York.

Sieburth, J.McN. \& P.G. Davis. 1982. The role of heterotrophic nanoplankton in the grazing and nurturing of planktonic bacterla in the Sargasso and Caribbean Sea. Ann. Inst. oceanogr., Paris 58(S): 285-295.

Sleburth, J.McN., V. Smetacek \& J. Lenz. 1978. Pelagic ecosystem structure: Heterotrophic compartments of the plankton and their relationship to plankton size fractions. Limnol. Oceanogr. 23: 1256-1263. Silver, M.W., J.G. Mitche11 \& D.L. Ringo. 1980. Siliceous nanoplankton. II. Newly discovered cysts and abundant choanoflagellates from the Wedde11 Sea, Antarct1ca. Mar. Biol. 58: 211-217.

Sorokin, Y.I. 1981. Microheterotrophic organisms in marine ecosystems. In: Longhurst, A.R. (ed.), Analysis of Marine Ecosystems, Academic Press, London, p. 293-342.

Sorokin, Y.I. \& J.E. Kogelschatz. 1979. Analysis of heterotrophic microplankton in an upwelling area. Hydroblologia 66: 195-208.

Stadelmann, P. \& M. Munawar. 1974. Blomass parameters and primary production at a nearshore and a midlake station of Lake4 Ontario during IFYGL. Proc. 17th Conf. Great Lakes Res. p. 109-119.

Takahash1, M. \& T. Hor1. 1984. Abundance of picophytoplankton in the subsurface chlorophyll maxlmum layer in subtropical and tropical waters. Mar. Biol. 79: 177-186.

Tumantseva, N.I. 1981. Some microzooplankton distribution patterns in the 
East Pacific upwelling region. Oceanol. 21: 80-85.

Tumantseva, N.I. \& Y.I. Sorokin. 1977. Microzooplankton of the equatorial upwelling in the Eastern Pacific Ocean. Pol. Arch. Hydrobio1. 24(S): 271-280.

Vinogradov, M.Y, E.A. Shushkina \& I.N. Kukina. 1976. Functional characteristics of a planktonic community in an equatorial upwelling region. Oceano1. 16: 67-76.

Waterbury, J.B., S.W. Watson, R.R.L. Guillard \& L.E. Brand. 1979. Widespread occurrence of a unfcellular, marine, planktonic cyanobacterium. Nature 277: 293-294.

Waterbury, J.B., S.W. Watson, F.W. Valols \& D. Franks. 1984. The role of unicellular cyanobacteria in the ocean. Paper presented at the 150 th National Meeting of the Americal Association for the Advancement of Sclence, New York, 24-29 May.

Watson, S.W., T.J. Novitsky, H.L. Quinby \& F.W. Valols. 1977. Determination of bacterlal number and blomass in the marine environment. Appl. Environ. Microbiol. 33: 940-946.

Will1ams, P.J. leB. 1981a. Microbial contribution to overall marine plankton metabolism: Direct measurements of respiration. Oceanologica Acta 4: $359-364$.

Williams, P.J. leB. 1981b. Incorporation of microheterotrophic processes into the classical paradigm of the planktonic food web. Kleler Meeresforsch. 5: 1-28. 
CHAPTER 2

MACROAGGREGATES AS MICROENVIRONMENTS

OF ELEVATED MICROBIAL BIOMASS AND ACTIVITY

IN THE NORTH ATLANTIC 


\section{ABSTRACT}

Counts were made by epifluorescence microscopy of the number of phototrophic and heterotrophic picoplankton, phototrophic and heterotrophic nanoplankton, and algae $>20 \mu \mathrm{m}$ on macroaggregates (macroscopic detrital particles) collected from surface waters of the North Atlantic. A Most Probable Number culture technique was also used to estimate the density of bacterivorous protozoa. All microblal populations enumerated were highly enriched on macroaggregates relative to their densities in the surrounding water. Microorganisms assoclated with aggregates were more important (on a per-particle basis) in open ocean environments because of the compounding effects of the lower density of microorganisms in the surrounding water from the open ocean (relative to the nearshore environment) and the higher density of microorganisms in macroaggregates from the open ocean (relative to macroaggregates from the nearshore environment). Documentation of the microbial colontzation of material released by ctenophores and appendicularia indicated that these materials are likely sources of macroaggregates since they supported microblal populations of the same order of magnitude as were observed on SCUBA-collected macroaggregates. Heterotrophic microflagellates dominated the bacterivorous protozoa cultured from both macroaggregates and the surrounding water, but dense populations of ciliates and amoebae were also present on macroaggregates. Protozoan populations on macroaggregates were sufficlently dense relative to the surrounding water that it is proposed that aggregates may be responsible for the planktonic existence of some spectes of bacter1vorous protozoa. 


\section{INTRODUCTION}

The term "macroaggregate" encompasses a wide spectrum of macroscopic detrital particles which have been varlously referred to as "organic aggregates", "detrital aggregates" or, more commonly, "marine snow". Their origin, activity and fate have been the subject of a number of investigations in recent years. These studies have demonstrated that macroaggregates constitute microenvironments characterized by high rates of primary productivity (A11dredge \& Cox, 1982; Knauer et al., 1982; Prezelin \& Alldredge, 1983) and heterotrophy (Silver et a1., 1978; Trent et a1., 1978; Caron et al., 1982) relative to equal volumes of the surrounding water. They have been shown to be sltes of nutrient enrichment (Shanks \& Trent, 1979) and have been suggested as a food source for epipelagic (Alldredge, 1972, 1976; Gerber \& Marshal1, 1974, 1982; Gottfrled \& Roman, 1983) or deep-sea organisms (Shanks \& Trent, 1980; Silver \& Alldredge, 1981).

Many potential sources of macroaggregates in the plankton have been documented, ranging from the secretions of benthic or pelagic organisms to dissolved organic matter. The possibility that the large pool of dissolved organic matter in the ocean is a source of particulate material was proposed and demonstrated more than 20 years ago (Baylor \& Sutcliffe, 1963; Riley, 1970). More exacting methodology has reconfirmed this mechanism for the formation of small aggregates (Johnson \& Cooke, 1980). In neritic environments the benthos can contribute significantly to the concentration of suspended macroaggregates. Coral reefs may release large amounts of mucus which add to the concentration of particules downstream from the reef (Johannes, 1967; Coles \& Strathmann, 1973; Gerber \& Marshall, 1974; Ducklow \& Mitchell, 1979). Macrophytes may also be a source of suspended particles in neritic waters (Iinley \& Flelds, 1982) and resuspension of sedimented material may cause large standing crops of macroscopic particles in some neritic and 
deep-sea environments (Bothner et a1., 1983).

In the open ocean, the contribution of the benthos to the macroaggregate concentration of the plankton is eliminated. Several important sources of detrital aggregates in this environment have been identified. These include discarded appendicularlan houses (Alldredge, 1976, 1979), mucus sloughed by ctenophores (Caron et al., 1982), fecal material of some tunicates (Pomeroy \& Delbel, 1980) and the mucus feeding structures of some pteropods (Gilmer, 1972; Caron et al., 1982). These highly disparate sources of particulate material result in a standing crop of macroaggregates that can vary temporally, spatially or compositionally.

Measurements of the density of macroaggregates confirm that they are numerically quite variable. A range of 0.2 to 14.0 aggregates $1^{-1}$ has been observed in neritic waters and a range of 0.001 to 5 aggregates $1^{-1}$ has been observed in the open ocean (Alldredge, 1979; Shanks \& Trent, 1980; Honjo \& Asper, 1982; Honfo et al., 1984). This variability is in contrast to the more untform (and more abundant) concentration of microscoplc aggregates in the ocean (Riley et a1., 1965; Gordon, 1970; Pomeroy, 1983). However, due to the sampling techniques used in these latter studies, disaggregation of larger particles cannot be ruled out.

Most microscopical studies of detrital aggregates have documented the occurrence of large populations of microorganisms associated with these aggregates. However, few studies have provided more than anecdotal information on the types and densities of these microorganisms (Trent et al., 1978; Silver et a1., 1978; Silver \& Alldredge, 1981; Caron et a1., 1982; S1lver et al., 1984). A more thorough investigation of these microorganisms is warranted since they are ultimately the primary mechanism for chemical alteration of the aggregate. They may also increase the nutritional value of these particles for planktonic detritivores or become avallable as a food 
source to a wider range of organisms through their association with relatively large particles. For example, Kopylov et al. (1981) showed that the copepod Acartia clausi did not feed directly on solitary microflagellates, but did consume large numbers of microflagellates when the protozoa were attached to detrital particles.

Work performed thus far on the ecological significance of macroaggregates has been carrled out in neritic waters (with one exception; Caron et al., 1982). The importance of macroaggregates to biological processes in the ol1gotrophic ocean has not been investigated, despite the fact that aggregates may be more important in the open ocean where the population density and/or activity in the surrounding water is reduced (relative to nearshore environments).

The present study arose from an investigation of the distribution of heterotrophic microflagellates in plankton communities (Chapter 1). Preliminary work (Caron et a1., 1982; Appendix IV) demonstrated the presence of highly elevated populations of microorganisms (including microflagellates) on macroaggregates from the Sargasso Sea relative to densities of these microorganisms in the water surrounding the aggregates. These results Indicated a potential importance of macroaggregates as concentration points of microorganisms and microbial activity in plankton communities.

Macroaggregates were collected from several environments in the North Atlantic and examined for microorganisms associated with them. Population densities on aggregates were compared to densities in the surrounding water. The results of this study suggest that macroaggregates are concentration points for microorganisms in the ocean. Aggregates may be responsible for the presence of some specles of bacterivorous protozoa in the plankton by creating enriched microenvironments of bacterial biomass in an otherwise oligotrophic environment. 
METHODS AND MATERIALS

Samples of macroaggregates were collected by divers on five oceanographic cruises in the North Atlantic from August 1981 to August 1983 ( $R / \mathrm{V}$ Atlantis II cruise \#109:3, 12 Aug to 11 Sept 1981; R/V Oceanus crulse \#115, 16 Feb to 5 Mar 1982; R/V Knorr cruise $\$ 94,18$ May to 6 June 1982; R/V Columbus Iselin cruise \#83-01, $19 \mathrm{Feb}$ to 12 Mar 1983; R/V Oceanus 12 Aug to 25 Aug 1983). Station locations are given in Figure 2.1. Sampling depths ranged from the surface to aproximately $35 \mathrm{~m}$. Macroaggregates were collected in sterile syringes to minimize the volume of surrounding water collected with the aggregates. However, some surrounding water was unavoldably collected with the aggregate samples. All population densities and enrichment factors given In the Results and Discussion were determined for this water-aggregate slurry. No attempt has been made to account for the dilution of microblal densities on the macroaggregate with this included water. Therefore, population densities and enrichment factors observed for these samples are conservative estimates of the degree of enrichment of aggregate populations relative to the surrounding water.

Most aggregate samples were pooled to provide enough materlal for all analyses. The volume of individual aggregates varied from approximately 0.2 $\mathrm{ml}$ to $>15 \mathrm{ml}$. The total number of aggregates and total volume was recorded for all pooled samples with the exception of the Continental Shelf sample during $R / V$ Oceanus cruise \#115. Aggregate number for this sample was estimated from the average volume per aggregate (estimated by divers from size measurements made at the time of collection) and the total sample volume. Pooled samples were welghted according to the number of aggregates they contained for the calculation of average population densities and enrichment factors.

Control samples (water collected near the aggregate, but not containing 
Figure 2.1. Stations locations for macroaggregate samples collected August 1981 to August 1983. Symbols Indicate the location of the samples relative to various hydrographic regimes; (D) Sargasso Sea, (O) Gulf Stream, (A) Continental Shelf water, ( $\nabla)$ Continental slope water, $(\bullet)$ Warm Core Ring 82B. 


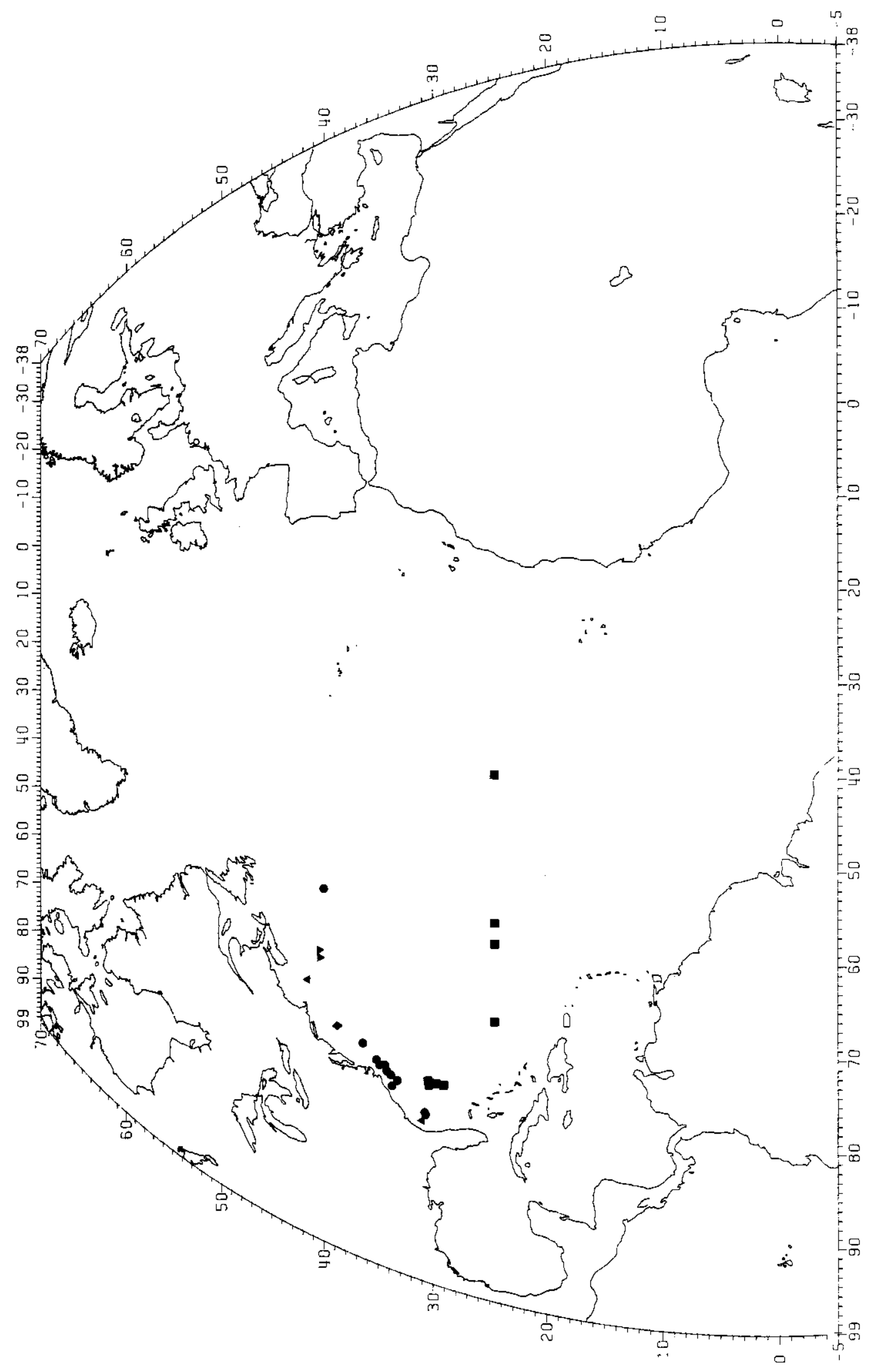


visible aggregates) were also collected by divers in sterile syringes. These samples were used to provide information about the densities of microorganisms in water surrounding the aggregates. Alternatively, Control samples were collected in acid-rinsed ( $0.1 \mathrm{~N}$ HCl) Niskin bottles at the depth of collection of the macroaggregates. Since Niskin bottle samples may include macroaggregates, the enrichment factors calculated using these Control samples are conservative estimates of the actual enrichment factors.

Macroaggregate samples were homogenized by vigorous shaking. Subsamples were taken for epifluorescence microscopy and protozoan culture. Samples for epifluorescence microscopy were preserved with glutaraldehyde at a final concentration of $1 \%$. Phototrophic and heterotrophic components of the

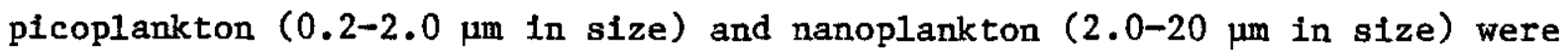
enumerated, as well as algae $>20 \mu \mathrm{m}$. Hpico (heterotrophic picoplankton, primarily heterotrophic bacteria and perhaps chemolithotrophic bacteria), Ppico (phototrophic picoplankton, primarily chroococcold cyanobacteria), Pnano (phototrophic nanoplankton), Hnano (heterotrophic nanoplankton, primarily heterotrophic microflagellates) and algae $>20 \mu \mathrm{m}$ were counted using the procedure in Appendix I. The number of bacterivorous protozoa in macroaggregates was also determined using a Most Probable Number (MPN) culture technique (Appendix II). This procedure provides an alternative method to microscopical counts for estimating the density of heterotrophic microflagellates (see Appendix II for discussion) as well as a method for estimating the density of bacterivorous amoebae and ciliates. Epifluorescence and MPN counts were also made on Control samples.

Colonization experiments were performed at sea to determine the potential for material released by gelatinous zooplankton to support bacterial and protozoan populations of the same order of magnitude as those found on SCUBA-collected macroaggregates. Mucus from the ctenophore Leucothea 
multicornis was collected by pipetting material sloughed from animals held in large aquaria. Some of this materlal was used immediately for the MPN culture technique while some was transferred to 41 aquaria containing unfiltered seawater at $20^{\circ} \mathrm{C} \pm 1^{\circ}$ in the dark to allow microbial colonization and growth. Subsamples were removed dally for three days and cultured using the MPN technique to estimate the number of bacterivorous protozoa present on the mucus. The MPN technique was also used with mucus freshly-released by the ctenophore Cestum veneris.

The carbon-to-nitrogen ratio of mucus from these two ctenophore species and of SCUBA-collected macroaggregates was also determined. Samples were filtered onto pre-combusted glass fiber filters, dried at $60^{\circ} \mathrm{C}$ for $24 \mathrm{hr}$, and stored frozen. Samples were dried for another $24 \mathrm{hr}$ just prior to analysis, and then analyzed for carbon and nitrogen by combustion in a Perkin-E1mer model 140 Elemental Analyzer.

Discarded appendicularian houses were also examined for microblal colonization. Unidentified appendicularla were maintained in aquaria until they discarded their houses. The houses were then removed to 41 aquaria containing unfiltered seawater at $20^{\circ} \mathrm{C} \pm 1^{\circ}$ in the dark. One house was preserved for epifluorescence counts of bacterla and total nanoplankton inftially and after two, three and four days of incubation. 
RESULTS AND DISCUSSION

It is clear from the present study (Tables $2.2 \& 2.4$ ) and from previous investigations that the density of microorganisms on marine snow varles over a wide range. Several factors may account for this varlability, including the source of the material (1.e. chemical composition), the time since its formation, and the presence of microorganisms in the surrounding water which are capable of exploiting this resource.

The source of the aggregate ultimately controls the magnitude of the microbial assemblage which will develop on the aggregate because it dictates the amount of labile organic material and nutrients avallable to microorganisms colonizing the aggregate. Identifying the source of individual marine snow particles is difficult due to the amorphous nature of most aggregates. Sources can be determined in cases where identifiable structures are present in the aggregates (such as appendicularian feeding nets (Alldredge, 1976; Silver \& Alldredge, 1981), but in most cases the source must be inferred from the appearance of the aggregate, and the presence of animals capable of producing such structures. For example, Caron et al. (1982) surmised that many of the macroaggregates which they collected were discarded mucus feeding webs of the pteropod Creseis virgula.

A range of aggregate volumes in excess of two orders of magnitude was observed by divers in this study. Relatively small $\left(0.2-1.0 \mathrm{~cm}^{3}\right)$ particles were usually observed at stations on the Continental Shelf while much larger particles ( $>20 \mathrm{~cm}$ in diameter) were observed at open ocean stations. The largest aggregates observed were identified as the discarded houses of the mesopelagic appendicularian Bathochordaeus charon (Barham, 1979). The disparity in individual aggregate volumes between different water masses suggests very different sources of macroaggregates for these environments. It is probable that differences in the average population densities of 
microorganisms on macroaggregates (Tables $2.2 \& 2.4$ ) were due to the different sources and therefore different chemical composition of the aggregates in these different environments. Epifluorescence Counts of Microorganisms

Densities of Hpico, Ppico, Pnano, Hnano and algae $>20 \mu \mathrm{m}$ as determined by eplfluorescence microscopy are given in Tables 2.1 and 2.2 for Control and macroaggregate samples, respectively. The samples have been grouped according to their location relative to large hydrographic regimes. The "Warm Core Ring" samples were taken on the edge of Ring 82B during R/V Knorr cruise The range of densities observed within an environment and an average density are presented for each population.

The range of densities observed in the Control samples (Table 2.1) can be explained by the large temporal and spatial variability associated with these populations (Chapter 1). Average density decreased for all the Control sample populations along a nearshore-to-offshore gradient. The magnitude of the decreases ranged from approximately two to 20 fold, with the largest decreases observed for algae $>20 \mu \mathrm{m}$. In contrast to Contro1 samples, average densities of microorganisms on macroaggregates increased along a nearshore-to-offshore gradient (Table 2.2). As mentioned above, this observation can probably be explained by differences in the source of the macroaggregates in the different environments. Increases in population densities on macroaggregates along a nearshore to offshore gradient were of the same magnitude as decreases in Control samples along this gradient.

These results suggest that densities of microorganisms on macroaggregates were not correlated with densitles in the surrounding water, and thus probably not directly related to productivity in the surrounding water. This is Indicated by a comparison of populations in macroaggregate and Control samples with photosynthetic pigment content of the surrounding water (Figure $2.2 \&$ 
Table 2.1. Epifluorescence counts of picoplankton, nanoplankton, and algae greater than $20 \mu \mathrm{m}$ in Contro1 and niskin bottle samples from surface waters of the North Atlantic. Ranges appear in parentheses and means $(\bar{X})$ for all samples in each water mass are glven below the ranges. Note that all multiplication factors (no. $\mathrm{ml}^{-1}$ ) are lower than those for macroaggregate samples.

\begin{tabular}{|c|c|c|c|c|c|c|}
\hline LOCATION & $\begin{array}{l}\text { NO. OF } \\
\text { SAMPLES }\end{array}$ & $\begin{array}{c}\text { HPICO } \\
\left(\times 10^{5} \mathrm{ml}^{-1}\right) \\
\end{array}$ & $\begin{array}{c}\text { PPICO } \\
\left(\times 10^{3} \mathrm{~m}^{-1}\right) \\
\end{array}$ & $\begin{array}{c}\text { PNANO } \\
\left(\times 10^{2} \mathrm{m1}^{-1}\right) \\
\end{array}$ & $\begin{array}{c}\text { HNANO } \\
\left(\times 10^{2} \mathrm{ml}^{-1}\right) \\
\end{array}$ & $\begin{array}{c}\text { ALGAE } \\
20 \mu \mathrm{m} \\
\left(\text { No. } \mathrm{m1}^{-1}\right) \\
\end{array}$ \\
\hline CONTINENTAL SHELF & 7 & $\begin{array}{c}(12.7-22.1) \\
\overline{\mathrm{X}}=19.2\end{array}$ & $\begin{array}{c}(18.7-29.8) \\
\overline{\mathrm{x}}=25.9\end{array}$ & $\begin{array}{c}(13.4-30.0) \\
\bar{x}=20.7\end{array}$ & $\begin{array}{c}(3.90-26.2) \\
\overline{\mathrm{X}}=16.6\end{array}$ & $\begin{array}{r}(5.30-123) \\
\dot{\bar{X}}=35.5\end{array}$ \\
\hline SLOPE & 5 & $\begin{array}{c}(6.61-18.5) \\
\bar{X}=14.9\end{array}$ & $\begin{array}{r}(8.41-100) \\
\overline{\mathrm{X}}=76.0\end{array}$ & $\begin{array}{c}(9.80-31.5) \\
\overline{\mathrm{X}}=20.8\end{array}$ & $\begin{array}{c}(8.16-32.1) \\
\overline{\mathrm{x}}=19.9\end{array}$ & $\begin{array}{c}(0.31-4.36) \\
\overline{\bar{x}}=2.94\end{array}$ \\
\hline WARM CORE RING & 5 & $\begin{array}{c}(5.50-11.0) \\
\overline{\bar{x}}=8.58\end{array}$ & $\begin{array}{c}(11.1-39.2) \\
\overline{\mathrm{X}}=40.3\end{array}$ & $\begin{array}{c}(6.68-27.5) \\
\overline{\bar{x}}=16.4\end{array}$ & $\begin{array}{c}(7.05-44.7) \\
\dot{\bar{x}}=19.1\end{array}$ & $\begin{array}{c}(0.96-1.92) \\
\overline{\mathrm{X}}=1.60\end{array}$ \\
\hline GULF STREAM & 18 & $\begin{array}{c}(1.74-14.9) \\
\overline{\bar{X}}=6.76\end{array}$ & $\begin{array}{c}(0.03-54.7) \\
\overline{\mathrm{X}}=15.8\end{array}$ & $\begin{array}{c}(0.45-16.3) \\
\overline{\mathrm{X}}=7.46\end{array}$ & $\begin{array}{c}(2.40-18.5) \\
\overline{\mathrm{X}}=7.04\end{array}$ & $\begin{array}{c}(0.24-39.3) \\
\overline{\mathrm{X}}=4.53\end{array}$ \\
\hline SARGASSO SEA & 18 & $\begin{array}{c}(2.66-9.47) \\
\bar{X}=4.76\end{array}$ & $\begin{array}{c}(1.29-35.2) \\
\overline{\mathrm{X}}=18.0\end{array}$ & $\begin{array}{c}(2.57-9.32) \\
\overline{\mathrm{X}}=5.82\end{array}$ & $\begin{array}{c}(2.70-14.7) \\
\overline{\bar{x}}=8.48\end{array}$ & $\begin{array}{c}(0.24-66.4) \\
\overline{\bar{x}}=11.5\end{array}$ \\
\hline TOTAL & 53 & $\bar{x}=8.66$ & $\bar{x}=25.9$ & $\ddot{\mathrm{X}}=10.8$ & $\overline{\mathrm{X}}=11.1$ & $\overline{\mathrm{X}}=10.6$ \\
\hline
\end{tabular}


Table 2.2. Eplfluorescence counts of picoplankton, nanoplankton, and algae greater than $20 \mu \mathrm{m}$ in macroaggregates from surface waters of the North Atlantic. Ranges appear in parentheses and means ( $\bar{X})$ for all samples 1 n each water mass are glven below the ranges. Pooled samples were welghted according to the number of aggregates ln the sample for the calculation of a mean.

\begin{tabular}{|c|c|c|c|c|c|c|}
\hline LOCATION & $\begin{array}{c}\text { NO. OF } \\
\text { AGGREGATES }\end{array}$ & $\begin{array}{c}\text { HPICO } \\
\left(\times 10^{6} \mathrm{ml}^{-1}\right)\end{array}$ & $\begin{array}{c}\text { PPICO } \\
\left(\times 10^{5} \mathrm{mI}^{-1}\right) \\
\end{array}$ & $\begin{array}{c}\text { PNANO } \\
\left(\times 10^{4} \mathrm{~m}^{-1}\right) \\
\end{array}$ & $\begin{array}{c}\text { HNANO } \\
\left(\times 10^{4} \mathrm{mi}^{-1}\right) \\
\end{array}$ & $\begin{array}{c}\text { ALGAE } \\
20 \mu \mathrm{m} \\
\left(\times 10^{3} \mathrm{ml}^{-1}\right) \\
\end{array}$ \\
\hline CONTINENTAL SHELF & 67 & $\begin{array}{c}(1.70-11.4) \\
\overline{\mathrm{X}}=6.58\end{array}$ & $\begin{array}{c}(0.96-7.27) \\
\overline{\bar{X}}=4.44\end{array}$ & $\begin{array}{c}(0.67-1.47) \\
\bar{X}=1.14\end{array}$ & $\begin{array}{c}(0.87-2.00) \\
\overline{\mathrm{X}}=1.52\end{array}$ & $\begin{array}{c}(0.11-8.67) \\
\overline{\bar{X}}=1.66\end{array}$ \\
\hline SLOPE & 523 & $\begin{array}{c}(5.45-16.0) \\
\overline{\bar{x}}=9.41\end{array}$ & $\begin{array}{c}(2.83-5.83) \\
\bar{x}=3.61\end{array}$ & $\begin{array}{c}(1.56-3.82) \\
\overline{\mathrm{X}}=2.27\end{array}$ & $\begin{array}{c}(1.26-3.93) \\
\overline{\mathrm{X}}=2.17\end{array}$ & $\begin{array}{c}(0.06-0.16) \\
\overline{\mathrm{X}}=0.08\end{array}$ \\
\hline WARM CORE RING & 71 & $\begin{array}{c}(2.56-16.3) \\
\overline{\mathrm{X}}=9.53\end{array}$ & $\begin{array}{c}(1.00-10.0) \\
\overline{\mathrm{X}}=5.56\end{array}$ & $\begin{array}{c}(2.84-6.68) \\
\overline{\mathrm{X}}=4.79\end{array}$ & $\begin{array}{c}(3.46-10.3) \\
\overline{\mathrm{X}}=6.93\end{array}$ & $\begin{array}{c}(0.03-0.04) \\
\overline{\mathrm{X}}=0.03\end{array}$ \\
\hline GULF STREAM & 289 & $\begin{array}{r}(0.91-250) \\
\dot{\bar{X}}=11.4\end{array}$ & $\begin{array}{c}(0.07-34.0) \\
\overline{\mathrm{X}}=6.59\end{array}$ & $\begin{array}{c}(0.16-12.9) \\
\overline{\mathrm{X}}=4.62\end{array}$ & $\begin{array}{c}(0.44-18.2) \\
\overline{\bar{X}}=4.65\end{array}$ & $\begin{array}{c}(0.01-11.0) \\
\overline{\bar{x}}=7.70\end{array}$ \\
\hline SARGASSO SEA & 103 & $\begin{array}{c}(1.12-16.7) \\
\overline{\mathrm{X}}=8.50\end{array}$ & $\begin{array}{c}(0.34-28.4) \\
\overline{\mathrm{X}}=7.18\end{array}$ & $\begin{array}{c}(0.28-8.59) \\
\overline{\mathrm{X}}=4.47\end{array}$ & $\begin{array}{c}(0.13-5.20) \\
\overline{\mathrm{X}}=2.57\end{array}$ & $\begin{array}{c}(0.002-108) \\
\overline{\mathrm{X}}=40.7\end{array}$ \\
\hline TOTAL & 1053 & $\overline{\mathrm{X}}=9.70$ & $\bar{x}=4.96$ & $\bar{x}=3.23$ & $\overline{\mathrm{X}}=3.17$ & $\overline{\mathrm{X}}=6.24$ \\
\hline
\end{tabular}


2.3). Hpico and total nanoplankton (Tnano) density in Control samples was positively correlated with chlorophyll a and phaeopigment concentration in the surrounding water. This result was expected since Pnano contribute to the concentration of pigments in the water and Hpico and Hnano are ultimately dependent on primary production for their nutrition. Densities of Hpico and Tnano on macroaggregates showed no correlation with pigment concentration of the surrounding water. This lack of correlation cannot be explained by varlable dilution of the macroaggregate sample with the surrounding water during collection. A negative correlation is suggested, but the number of data points at high pigment concentrations was not sufficient to confirm this trend. A lack of correlation between populations in macroaggregates and pigment concentration in the surrounding water indicates that microbial processes in the aggregates may be independent of processes in the surrounding water, and are more dependent on features within the microenvironment (e.g. concentration of labile DOM and POM; nutrients regenerated within the aggregate matrix). However, the overall contribution of aggregate-related processes would ultimately be dependent upon primary productivity, since the organisms or processes resulting in aggregate formation are directly or Indirectly dependent on primary productivity.

The relative contribution of microorganisms on marine snow particles to populations in the surrounding water was determined by calculating enrichment factors for each environment (Table 2.3). These factors are a ratio of the average density of microorganisms in macroaggregates to their average density in the surrounding water. These values indicate the minimal amount of enrichment since the aggregate samples unavoldably contalned some surrounding water. In general, greater enrichment factors were observed for open ocean samples. This trend was a combined effect of decreased average density in the surrounding water and increased average density in the aggregates. 
Figure 2.2. Comparison of bacterial (Hpico) abundance as determined by epifluorescence microscopy on macroaggregates and in the surrounding water with chlorophyll-a + phaeopigment concentration in the surrounding water. Symbols indicate data from individual cruises.

(A) Hpico abundance in Control samples plotted versus pigment concentration at the same depth. The curve was fitted by eye.

(B) Hplco abundance in macroaggregate samples plotted versus pigment concentration in the surrounding water at the same depth. 

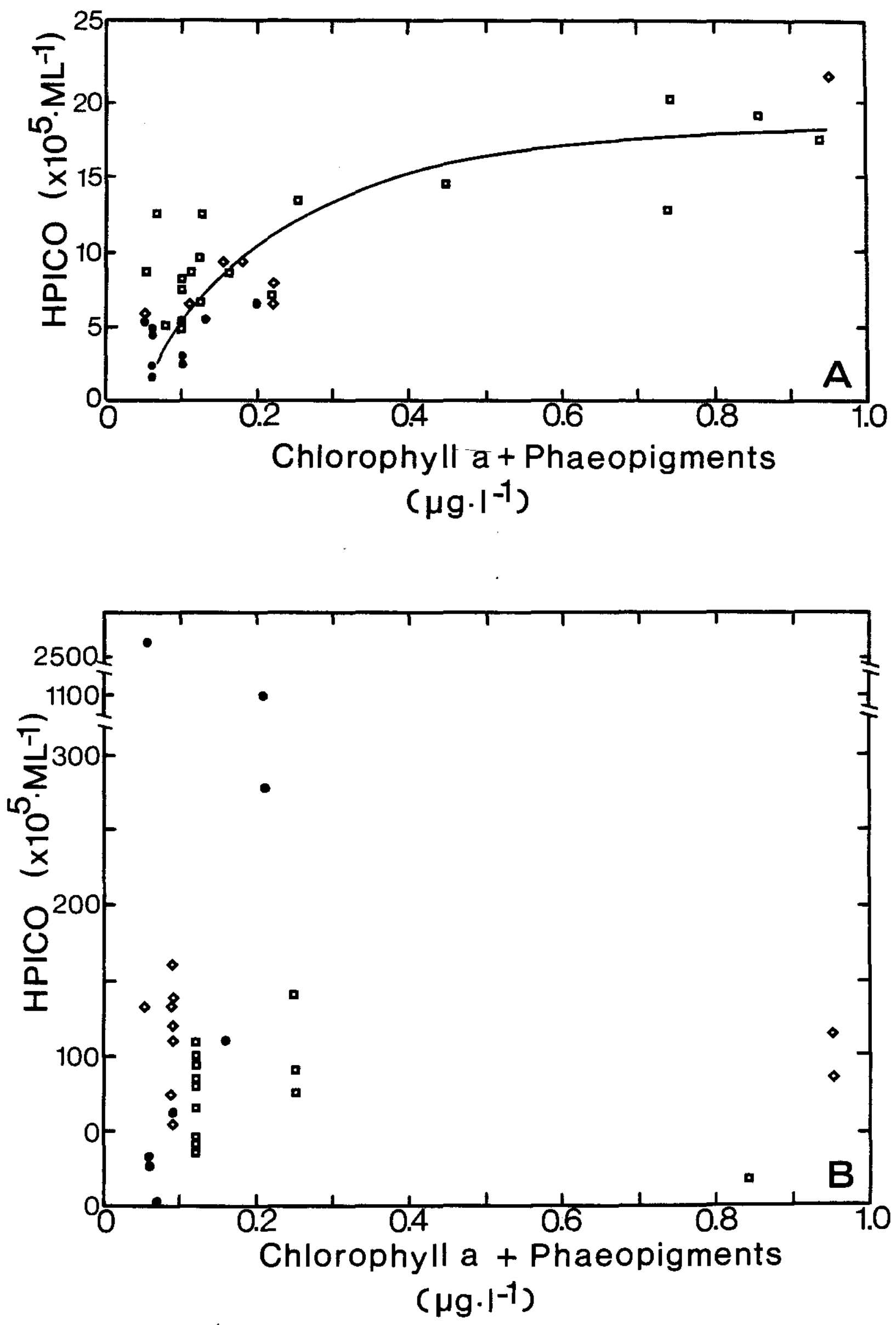
F1gure 2.3. Comparison of total nanoplankton (Tnano) abundance as determined by epifluorescence microscopy on macroaggregates and in the surrounding water with chlorophyll-a + phaeoplgment concentration in the surrounding water. Symbols indicate data from individual cruises.

(A) Tnano abundance in Control samples plotted versus pigment concentration at the same depth. The curve was fitted by eye.

(B) Tnano abundance in macroaggregate samples plotted versus pigment concentration in the surrounding water at the same depth. 


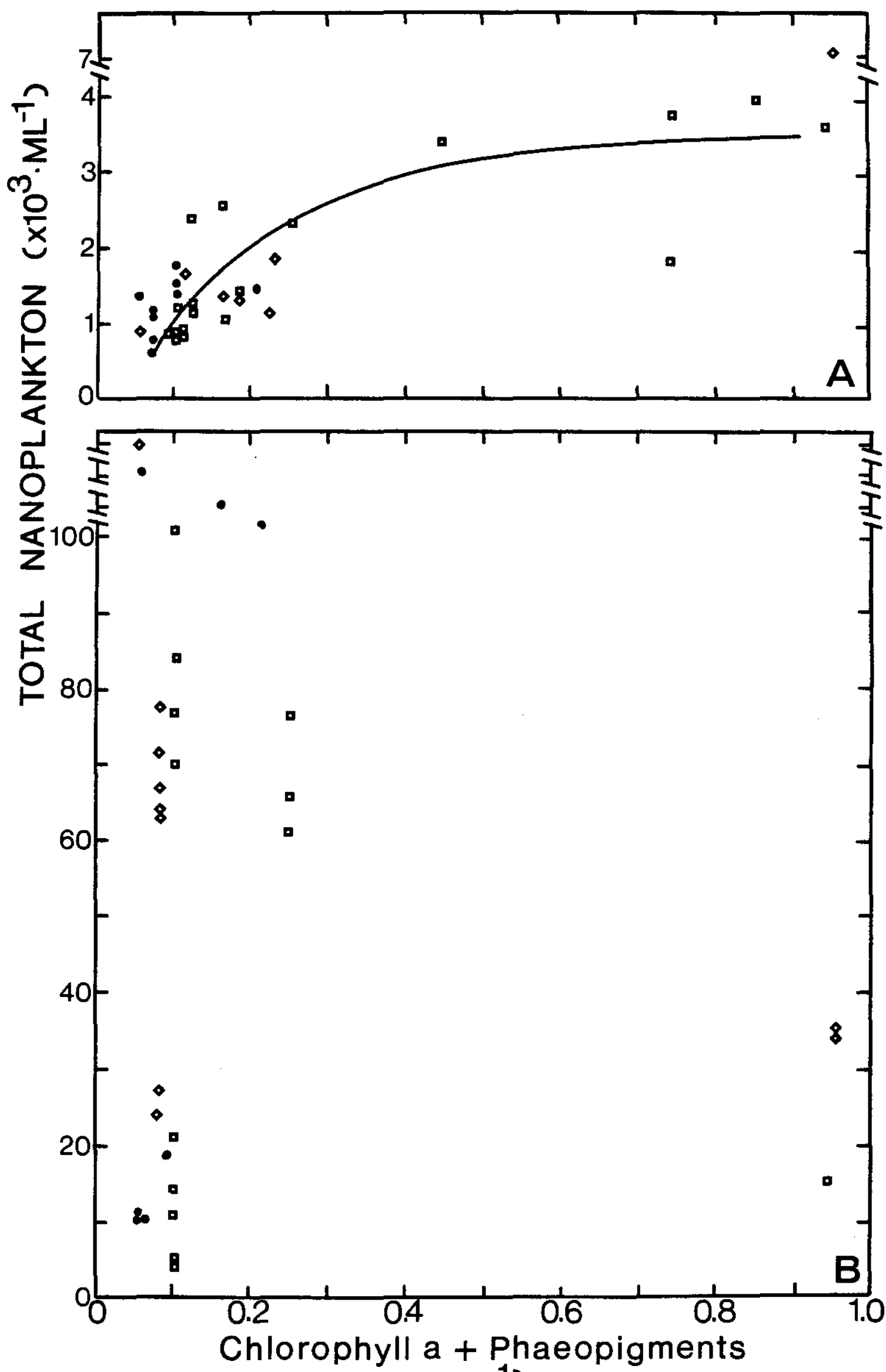

$\left(\mu \mathrm{g} \cdot \mathrm{I}^{-1}\right)$ 
Table 2.3. Enrichment factors for picoplankton, nanoplankton, and algae greater than $20 \mu \mathrm{m}$ in macroaggregates from surface waters of the North Atlantic. Factors represent the ratio of the averaged density of a population in the macroaggregates to its density in the surrounding water.

\begin{tabular}{|c|c|c|c|c|c|c|}
\hline LOCATION & $\begin{array}{c}\text { N0. OF } \\
\text { AGGREGATES }\end{array}$ & HPICO & PPICO & PNANO & HNANO & $\begin{array}{r}\text { ALGAE } \\
20 \mu m \\
\end{array}$ \\
\hline CONTINENTAL SHELF & 67 & 3.2 & 18.7 & 6.9 & 17.0 & 24.2 \\
\hline SLOPE & 523 & 14.3 & 43.0 & 23.2 & 26.6 & 267 \\
\hline WARM CORE RING & 71 & 10.4 & 19.1 & 24.3 & 31.1 & 19.7 \\
\hline GULF STREAY & 289 & 18.7 & 42.1 & 67.1 & 114 & 1300 \\
\hline SARGASSO SEA & 103 & 17.9 & 42.1 & 57.5 & 51.5 & 699 \\
\hline
\end{tabular}


Hpico (primarily bacterla) showed the lowest enrichment factors of all the populations enumerated. Average Hpico density at the Continental Shelf stations was close to its density in the surrounding water (enrichment factor =3.2). In comparison, macroaggregates from all other environments had enrichment factors for Hpico which were greater than 10 .

Bacterial morphological types were quite different in macroaggregates and surrounding water (F1gure 2.4). Bacterla from macroaggregates (F1gure 2.4b) were generally (but not always) much larger than typical bacterloplankton (Figure 2.4a). Long, filamentous cells, absent in the bacterfoplankton, were common in aggregates. These morphological differences have been noted previously (Caron et al., 1982). They indicate that the numerical estimates of bacteria underestimate the differences in bacterial biomass between Control and aggregate samples.

Ppico (primarily chroococcold cyanobacteria) was 10-20x less abundant than bacteria in macroaggregates (Tables 2.2). However, enrichment factors were greater for Ppico than Hpico (Table 2.3). Like the bacteria, enrichment factors for Pplco were greater for offshore stations than for Shelf stations. Ppico was a very conspicuous component of macroaggregates. This population occurred as free-living cells, in fecal pellets and as symbionts (Figure 2.5). Large numbers of Ppico were often observed in fecal pellets found in macroaggregates (Figure 2.5a,b). These microorganisms apparently pass through the guts of microcrustaceans without being digested (Johnson et al., 1982). The potential benefit of this digestion resistance has been discussed by S1lver \& Alldredge (1981).

Cyanobacterla also occurred in macroaggregates as the symbionts of a number of organtsms. Figure 2.5c,d shows the diatom Hemiaulus membranaceus which was associated with marine snow (and also in the surrounding water) in the Sargasso Sea, Gulf Stream and Shelf environments in February 1982. The 
Figure 2.4. Epifluorescence photomicrographs of DAPI-stained bacteria in a Control sample (A) and a macroaggregate sample (B). Ten ml of sample was filtered onto a Nuclepore filter for the Control sample while $0.5 \mathrm{ml}$ of sample was filtered for the macroaggregate sample. Bars $=5.0 \mu \mathrm{m}$. 


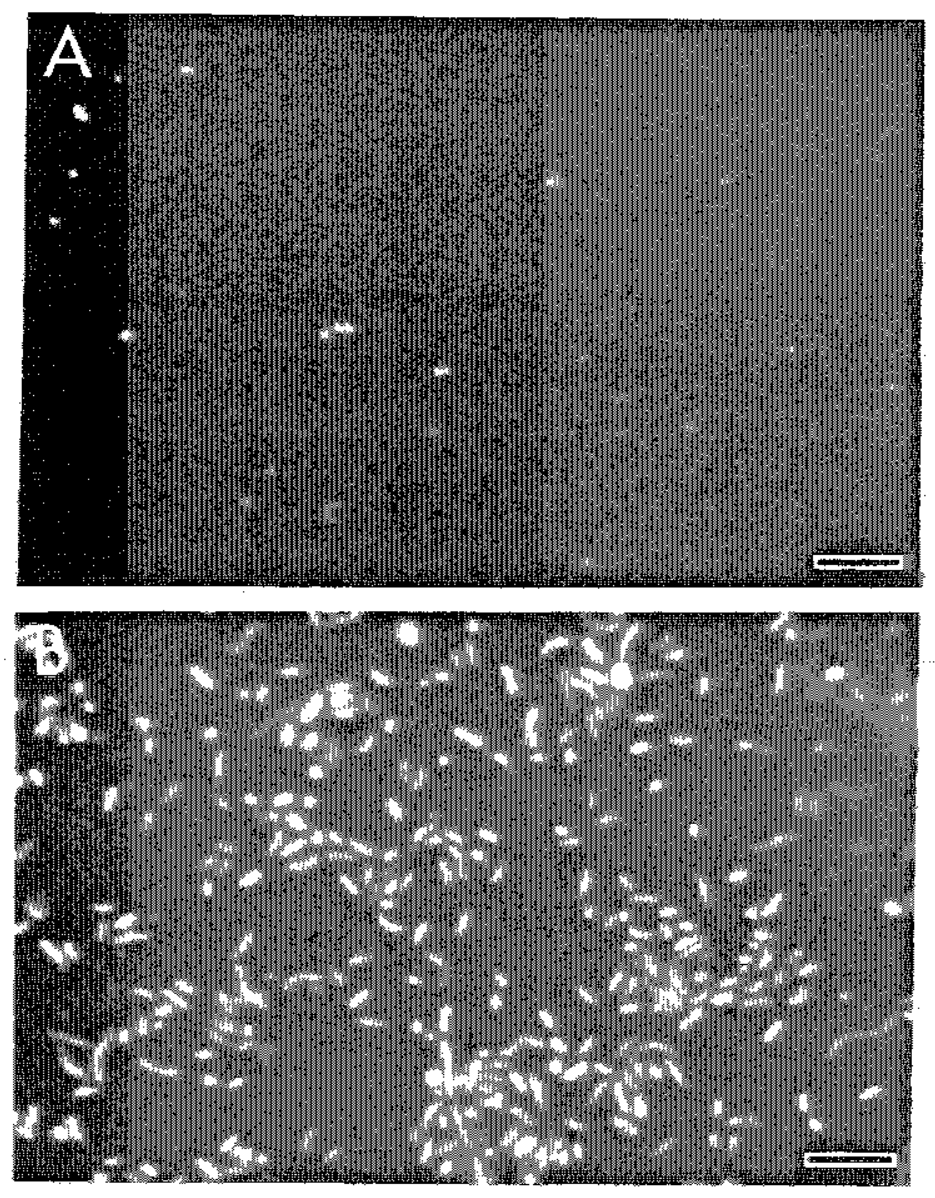


F1gure 2.5. Photomicrographs of cyanobacteria in macroaggregates. Transmitted white light (A) and epifluorescence (B) photomicrographs of Synechococcus-like cyanobacteria (yellow cells) in a fecal pellet from marine snow. Transmitted white light (C) and eptfluorescence (D) photomicrograph of the diatom Hemfaulus membranaceus with the Intracellular cyanobacterium Richella intracellularis. The diatom chloroplasts fluoresce red (due to chlorophy11-a) while $\underline{\mathrm{R}}$. intracellularls fluoresces yellow (due to phycoerythrin). Epifluorescence photomicrograph (E) of chroococcoid cyanobacteria from marine snow. Evidence of division planes suggest growth within the marine snow microenvironment. Bars $=10 \mu \mathrm{m}$. 

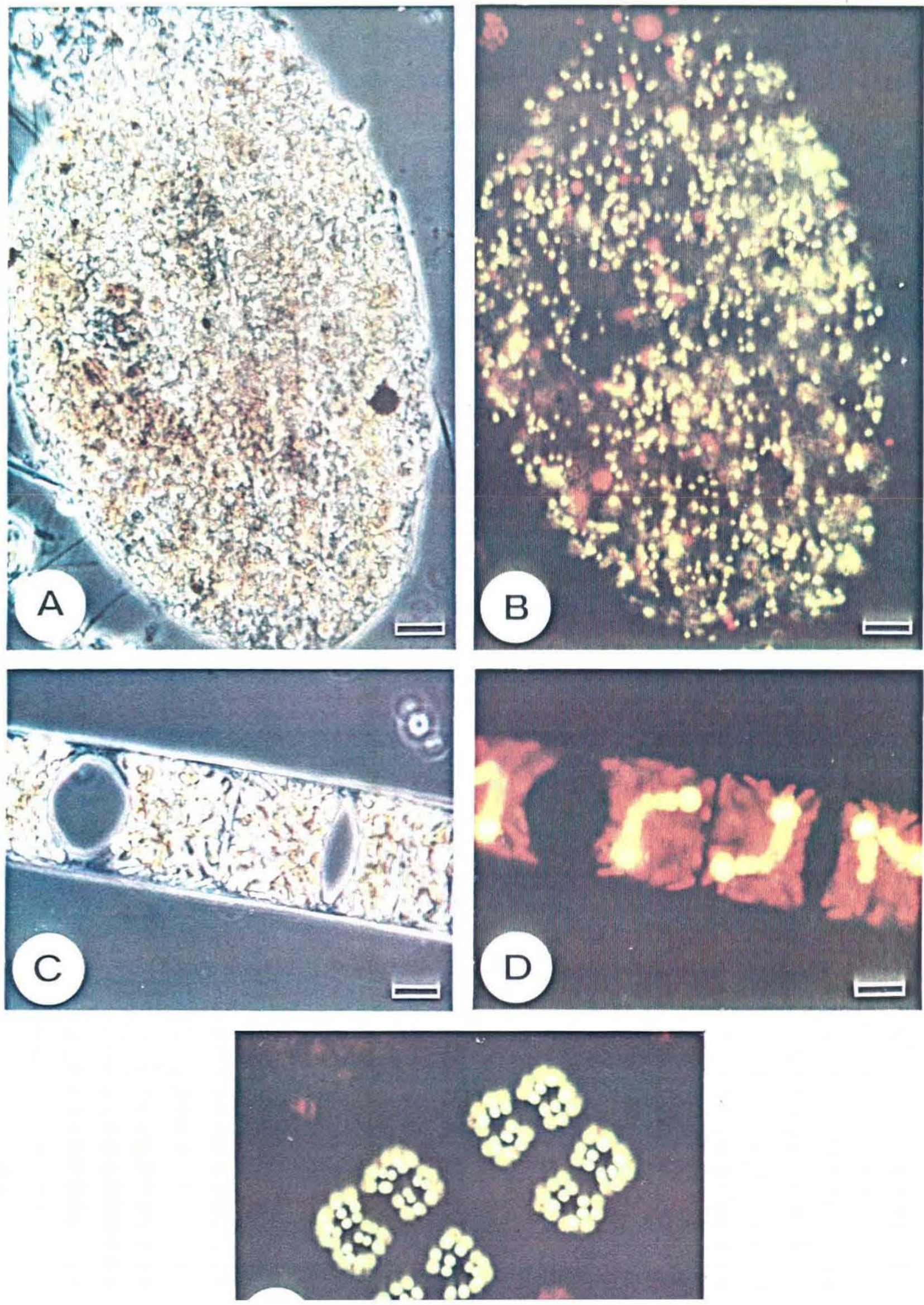
Intracellular symbiotic cyanobacterium Richelia Intracellularis was found in virtually all Hemlaulus cells collected at these locations and was also found In association with the diatom Rhizosolenia sp. In these samples. Cyanobacteria were also observed as symbionts attached to the cell surface of the heterotrophic dinoflagellate Ornithocercus sp.. These symbioses have been previously described (Kimor et a1., 1978; Taylor, 1982). They exemplify the diversity of trophic relationships in which chroococcold cyanobacteria particlpate.

Large numbers of cyanobacteria which were not assoclated with fecal pellets or other microorganisms also occurred in the macroaggregates. In many cases these cells showed evidence of recent cell division (Figure 2.5e), supporting the argument of Silver \& Alldredge (1981) that the marine snow microenvironment may allow the growth of phototrophs as well as heterotrophs.

Pnano and Hnano populations in macroaggregate samples were nearly equal. This partty was also observed in the Control samples of this study and in vertical profiles throughout the North Atlantic (Chapter 1). It was expected that Hnano density would greatly exceed Pnano density in the macroaggregates because of the large bacterial populations (potential prey) present in the aggregates. If grazing pressure is simflar for both Pnano and Hnano populations in the aggregates, then it can be concluded that Pnano and Hnano benefit equally by their association with these particles. Enrichment factors were similar for Pnano and Hnano (within a factor of approximately two) and showed greater values for offshore samples than for Shelf samples. Determination of turnover times of Pnano and Hnano must be performed to resolve this question.

Algae $>20 \mu \mathrm{m}$ showed the highest enrichment factors. Values for these microorganisms were much higher in the open ocean then the enrichment factors for Ppico or Pnano. This was due in part to the lower density of algae $>20$ 
um In the open ocean, but may also be a result of "pre-inoculation" of macroaggregates with algal populations. For example, incurrent filters of appendicularia concentrate particles which are larger than the mesh of the filter. This activity results in a macroaggregate that already contains a high density of these particles when the house is discarded by the animal. Since many of the aggregates in the Gulf Stream and Sargasso Sea were identified as discarded appendicularian houses, it is probable that the very high enrichment factors for algae $>20 \mu \mathrm{m}$ can be explained in this way. Culture of Bacterivorous Protozoa

A Most Probable Number (MPN) culture technique was used to estimate the density of bacterivorous protozoa in macroaggregates and in the surrounding water (Table 2.4). Microflagellates numerically dominated the protozoan fauna in all marine snow and Control samples. Out of 720 macroaggregates cultured, $100 \%$ showed positive growth of microflagellates, while $93 \%$ and $88 \%$ showed positive growth of amoebae and clliates, respectively. The largest volume cultured from any macroaggregate sample was $1.0 \mathrm{ml}$. However, most of these aggregates were pooled samples, and the true particle-to-particle variability was masked by this sampling procedure. For example, out of 13 particles which were collected and cultured individually, 13 contained culturable microflagellates while only four contained culturable cillates or amoebae. Ciliates and amoebae can be quite dense when present, however, and this may account for their relatively high frequency in pooled samples.

Microflagellates, on the other hand, appear to be truly indigenous members of the aggregate microcommunity. Their density in aggregate samples varied great1y $\left(17-23,000 \mathrm{ml}^{-1}\right)$, but they were at least demonstrable in a11 samples. Their occurrence in all macroaggregate samples may be a consequence of their ublquity in the surrounding water. Out of 78 culture attempts of SCUBA-collected Control samples and seawater samples from acid-rinsed Niskin 
Table 2.4. Most Probable Number estimates (no. $\mathrm{ml}^{-1}$ ) of protozoa in macroaggregates from surface waters of the North Atlantic. Ranges appear in parentheses and means $(\overline{\mathrm{X}})$ for all samples in each water mass are given below the ranges. Pooled samples were weighted according to the number of aggregates in the sample for calculation of the mean. "UN" Indicates that no positive cultures were obtained at the lowest dilution (theoretical 1imit of detection $=0.37 \mathrm{~m}^{-1}$ ).

\begin{tabular}{|c|c|c|c|c|}
\hline \multirow[b]{2}{*}{ LOCATION } & \multirow{2}{*}{$\begin{array}{c}\text { NO. OF } \\
\text { AGGREGATES }\end{array}$} & \multicolumn{3}{|c|}{ MPN $\mathrm{ML}^{-1}$} \\
\hline & & CILIATES & FIAGELLATES & AMOEBAE \\
\hline CONTINENTAL SHELF & 67 & $\begin{array}{l}(\mathrm{UN}-8.59) \\
\overline{\mathrm{X}}=6.2\end{array}$ & $\begin{array}{c}(17 \cdot 3-879) \\
\overline{\mathrm{X}}=381\end{array}$ & $\begin{array}{c}(0.37-8.59) \\
\overline{\bar{X}}=3.8\end{array}$ \\
\hline SLOPE & 209 & $\begin{array}{c}(3.72-17.3) \\
\bar{X}=8.5\end{array}$ & $\begin{array}{l}(879) \\
\bar{X}=879\end{array}$ & $\begin{array}{c}(1.73-85.9) \\
\overline{\mathrm{X}}=21.7\end{array}$ \\
\hline WARM CORE RING & 71 & $\begin{array}{l}(0.35-3.50) \\
\overline{\mathrm{X}}=1.9\end{array}$ & $\begin{array}{c}(94 \cdot 2-415) \\
\bar{X}=257\end{array}$ & $\begin{array}{c}(0.35-3.50) \\
\overline{\mathrm{X}}=1.9\end{array}$ \\
\hline GULF STREAM & 282 & $\begin{array}{l}(\mathrm{UN}-180) \\
\overline{\mathrm{X}}=13.2\end{array}$ & $\begin{array}{c}(180-23100) \\
\bar{X}=3180\end{array}$ & $\begin{array}{r}(0.37-180) \\
\overline{\mathrm{X}}=53.2\end{array}$ \\
\hline SARGASSO SEA & 91 & $\begin{array}{l}(U N-240) \\
\bar{X}=17.3\end{array}$ & $\begin{array}{c}(85.9-10000) \\
\overline{\mathrm{X}}=868\end{array}$ & $\begin{array}{c}(U N-37.2) \\
\overline{\mathrm{X}}=22.0\end{array}$ \\
\hline TOTAL & 720 & $\overline{\mathrm{x}}=10.2$ & $\overline{\mathrm{X}}=1420$ & $\overline{\mathrm{x}}=31.1$ \\
\hline
\end{tabular}


bottles (the largest volume cultured from each sample was $100 \mathrm{ml}$ ), all 78 samples showed positive growth of microflagellates with an overall average density of $1.7 \mathrm{ml}^{-1}$. In contrast, 45 samples (58\%) showed positive growth of amoebae with an average density of $0.04 \mathrm{ml}^{-1}$ in those samples showing growth. Only six samples (8\%) showed positive growth of clliates, with an average density of $0.005 \mathrm{ml}^{-1}$ in those samples showing growth. These results suggest that the varlability associated with the presence or absence of bacterivorous clliates and amoebae in macroaggregates may be due to the low abundance of these protozoa in the surrounding water, and therefore the relatively low probability that they will encounter an aggregate.

Because the MPN culture technique was designed to estimate the number of bacterivorous protozoa, it may well have underestimated the total number of protozoa by not provlding food for herbivorous/carnivorous protozoa. Microscopical observation gave ample evidence of herbivory by ciliates in macroaggregates (F1gure 2.6). Also, taxonomic characterization of ciliates found in some of these macroaggregate samples has shown a much higher species diversity than can be cultured (Small et al., 1983). Duplicate sets of MPN cultures were performed on one macroaggregate sample (four pooled aggregates) from the Gulf Stream. Microalgae (Dunaliella tertiolecta and Isochrysis galbana) were added to one of these sets. The density of cillates determined for this sample was not different for the two MPN sets, although species diversity was higher in the cultures containing algae. These results suggest that bacterivorous ciliates dominated the population of culturable ciliates. Enrichment factors were determined for the MPN counts of bacterivorous protozoa in the macroaggregate samples as they were for epifluorescence counts (Table 2.5). These enrichment factors were higher than enrichment factors for epifluorescence counts, exceeding four orders of magnitude in two cases. They did, however, follow a pattern similar to the epifluorescence counts in that 
Figure 2.6. Transmitted white 11ght and epifluorescence photomicrographs of three species of cillates from macroaggregates. A,C and $E$ are phase contrast photomicrographs showing cell size and shape. B, D and F are epifluorescence photomicrographs of autofluorescent cell contents in these ciliates. Red color indicates ingested Pnano in food vacuoles while yellow color indicates the presence of chroococcold cyanobacteria. The green color is natural fluorescence from the protozoan cytoplasm. Bars $=10 \mu \mathrm{m}$. 

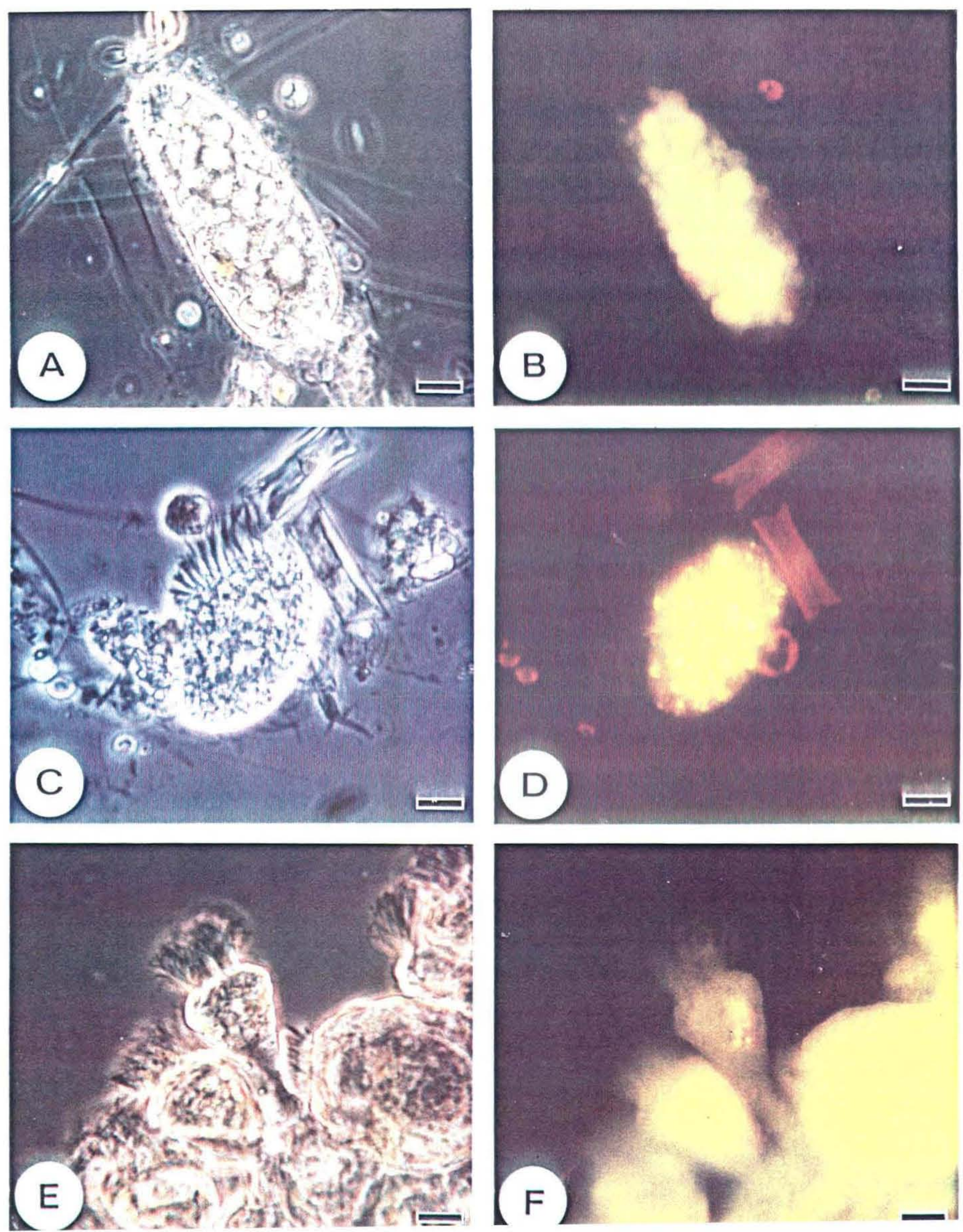
Table 2.5. Enrichment factors for protozoa in macroaggregates from surface waters of the North Atlantic. Factors represent the ratio of the averaged density of a population in the macroaggregates to its density in the surrounding water.

\begin{tabular}{|c|c|c|c|c|}
\hline \multirow[b]{2}{*}{ LOCATION } & \multirow{2}{*}{$\begin{array}{c}\text { NO. OF } \\
\text { AGGREGATES }\end{array}$} & \multicolumn{3}{|c|}{ MPN $\mathrm{ML}^{-1}$} \\
\hline & & CILIATES & FLAGELLATES & AMOEBAE \\
\hline CONTINENTAL SHELF & 67 & $-*$ & 476 & 413 \\
\hline SLOPE & 209 & - & 508 & 586 \\
\hline WARM CORE RING & 71 & - & 273 & - \\
\hline GULF STREAM & 282 & 9080 & 7640 & 2280 \\
\hline SARGASSO SEA & 91 & 77400 & 18400 & 6190 \\
\hline
\end{tabular}

(*) Indicates that no positive cultures were obtained for the control samples. Therefore concentration factors cannot be determined. 
greater enrichment factors were observed for offshore samples than for Shelf samples. The large enrichment factors can presumably be explained by the elevated concentrations of picoplankton in the aggregate microenvironment. Also, in the case of clilates and amoebae, densities in the surrounding water were extremely low in the open ocean environments. Silver et al. (1978) noted enrichment factors $>8000$ for direct counts of ciliates in macroaggregates. Enrichment factors in this study are in agreement with their values.

Direct counts of cillates and amoebae were not performed in this study so it is not possible to compare the two counting techniques for these populations. However, Inano counts (determined by epifluorescence microscopy) and bacterivorous microflagellate counts (determined by the MPN technique) should theoretically yield comparable results (Table 2.6). MPN estimates averaged two to three orders of magnitude lower than the direct counts. This large discrepancy may have occurred for a number of reasons (Appendix II). Direct counts cannot differentiate microflagellates which are herbivorous rather than bacterivorous, or microflagellates which are morlbund or dead. Also, gametes of planktonic protozoa or metazoa may be included in the direct counts, but do not function as bacterivores. These factors would result in an overestimation of the number of bacterivorous microflagellates by the epifluorescence technique. In addition, it is doubtful that all bacterivorous mfcroflagellates are culturable. Lack of growth in the MPN cultures would result in underestimation of the number of microflagellates in a sample.

There was a noticable difference in the ratio of MPN to direct counts for macroaggregate and Control samples (Table 2.6). The ratio for macroaggregate samples averaged $38.5 \mathrm{x}$ the ratio for Control samples. MPN estimates accounted for an average of $5.0 \%$ of the direct count estimates in macroaggregates, whereas it accounted for only $0.13 \%$ of the direct count estimates in Control samples. There are several possible explanations for this difference. It is 
Table 2.6. A comparison of the number of heterotrophic microflagellates in macroaggregate and Control water samples as shown by the Most Probable Number culture technique and by direct (epifluorescence) counts. This ratio expresses the Most Probable Number estimate (MPN) as a percentage of the corresponding direct count (DC).

$($ MPN $\times 100): D C$

\begin{tabular}{|c|c|c|c|}
\hline SAMPLE TYPE & $\begin{array}{l}\text { NO. OF } \\
\text { SAMPLES }\end{array}$ & RANGE & AVERAGE \\
\hline Controls & 46 & $0.002-1.6$ & 0.13 \\
\hline Macroaggregates & 708 & $0.27-51.7$ & 5.05 \\
\hline
\end{tabular}


possible that macroaggregates are colonized by species of microflagellates which are inherently more amenable to culture than specles dominating the surrounding water. Another possibility is that Control samples simply contain a higher percentage of dead or mortbund microflagellates than macroaggregates, perhaps due to the low bacterial density. An experiment comparing the MPN and direct counting techniques on cultured species of microflagellates lends some credence to this hypothesis (Appendix II). When microflagellate cultures are sampled during $10 \mathrm{~g}$ phase growth, the MPN:DC was greater than for a sample taken during stationary phase. Microorganisms which were no longer capable of growth in the MPN cultures were st111 sufficlently intact to be enumerated by the direct counting technique. The macroaggregate and Control samples may provide an analogy, where macroaggregates contain microflagellate populations which are closer to log phase growth than the population in the Controls. This reasoning could explain why the MPN and direct count estimates were similar in some instances (in one case the MPN estimate was $50 \%$ of the direct count estimate; Table 2.6). An increase in the ratio of the MPN estimate to the direct count estimate has been correlated with an increasing proportion of plcoplankton in the $<20 \mu$ plankton (Chapter 1). The ratio for macroaggregate samples observed in this study $(\bar{X}=5.05)$ was greater than the ratio observed for the most eutrophic environment in that study (Lake Ontario, $\bar{x}=1.9$ ). Therefore, prey density, and its resulting effect on the nutritional state of the protozoa, may control the relationship between the MPN and direct counting techniques.

Other possible explanations exist, however. Control samples may contain a higher proportion of non-phagotrophic microorganisms (e.g. gametes) which would not grow in culture. Also, a larger proportion of herbivorous flagellates may occur in Control Samples. Herbivory is well-documented among heterotrophic dinoflagellates (F1gure 2.7; Kimor, 1981), and it has been 
estimated that the majority of open ocean species of dinoflagellates are heterotrophs (Morey-Gaines, in press).

Colonization Experiments

Experiments concerning the microblal colonization of structures or material released by gelatinous zooplankton suggest that these materials may be an Important source of macroaggregates. Mucus released by ctenophores (Figure 2.8) showed enriched populations (relative to the surrounding water) of microflagellates within $2 \mathrm{hr}$ after release, perhaps an indication of bacterial growth on the surface of the ctenophore. Cillates and amoebae were present after day 1 and all three protozoan groups reached very high densities by day 3. Likewise, bacteria and Tnano were initially enriched on appendicularian houses (Figure 2.9) relative to the surrounding water, and increased by more than an order of magnitude over a four day perfod. The colonization rate and microblal density on appendicularian houses observed in this study agrees with colonization data presented by Davol1 (1983).

Population densities on both of these substrates after three days of incubation exceeded densities of these populations observed in most SCUBA-collected macroaggregates. Differences in the density of populations developing on ctenophore mucus or appendicularian houses in laboratory experiments and those on SCUBA-collected marine snow may be due to differences In composition of the two substrates, or to the state of colonization of SCUBA-collected macroaggregates. Older, more refractory macroaggregates may no longer support large numbers of microorganisms. Alternatively, marine snow in surface waters may be relat1vely young and in the early stages of colonization, while older, well-colonized aggregates have sunk out of surface waters. Cropping of protozoa by zooplankton or dispersion of the populations into the surrounding water (either naturally or during sampling) also would tend to lower densities on SCUBA-collected aggregates. 
Figure 2.7. Six specles of heterotrophic dinoflagellates from marine snow. Note the Ingested Pnano in the dinoflagellate in A. Bars $=20 \mu \mathrm{m}$. 

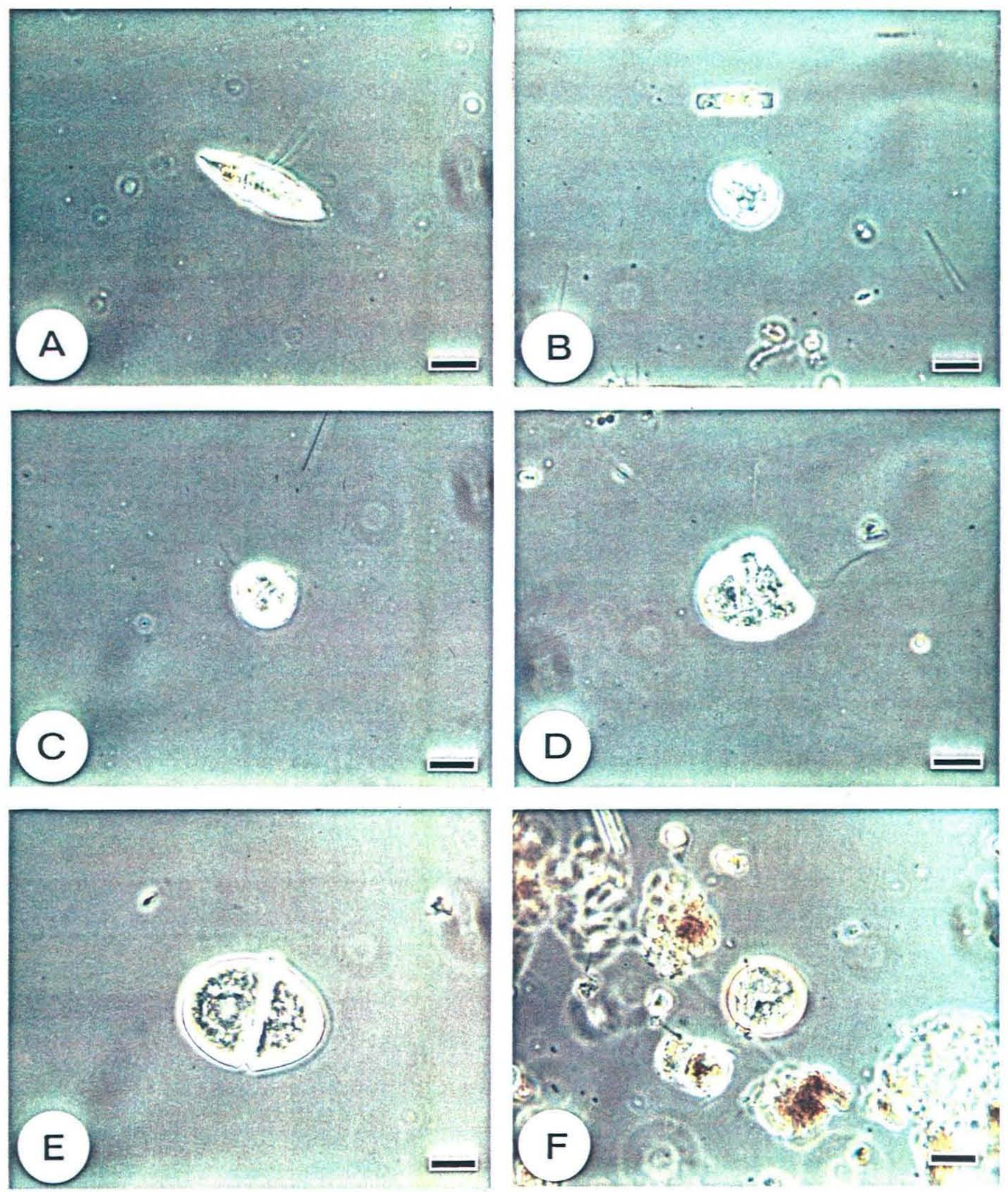
Figure 2.8. Most Probable Number estimates of bacterivorous protozoa colonizing mucus released from the ctenophores Leucothea multicornis and Cestum veneris and incubated in 41 of unfiltered seawater at $20^{\circ} \mathrm{C}$ in the dark. Symbols connected by solid lines represent microblal densities in subsamples of pooled mucus. Symbols labelled "Leu" and "Ces" represent samples collected and incubated independently from the pooled mucus.

(E) Flage11ates

(†) Cillates

(C) Amoebae 


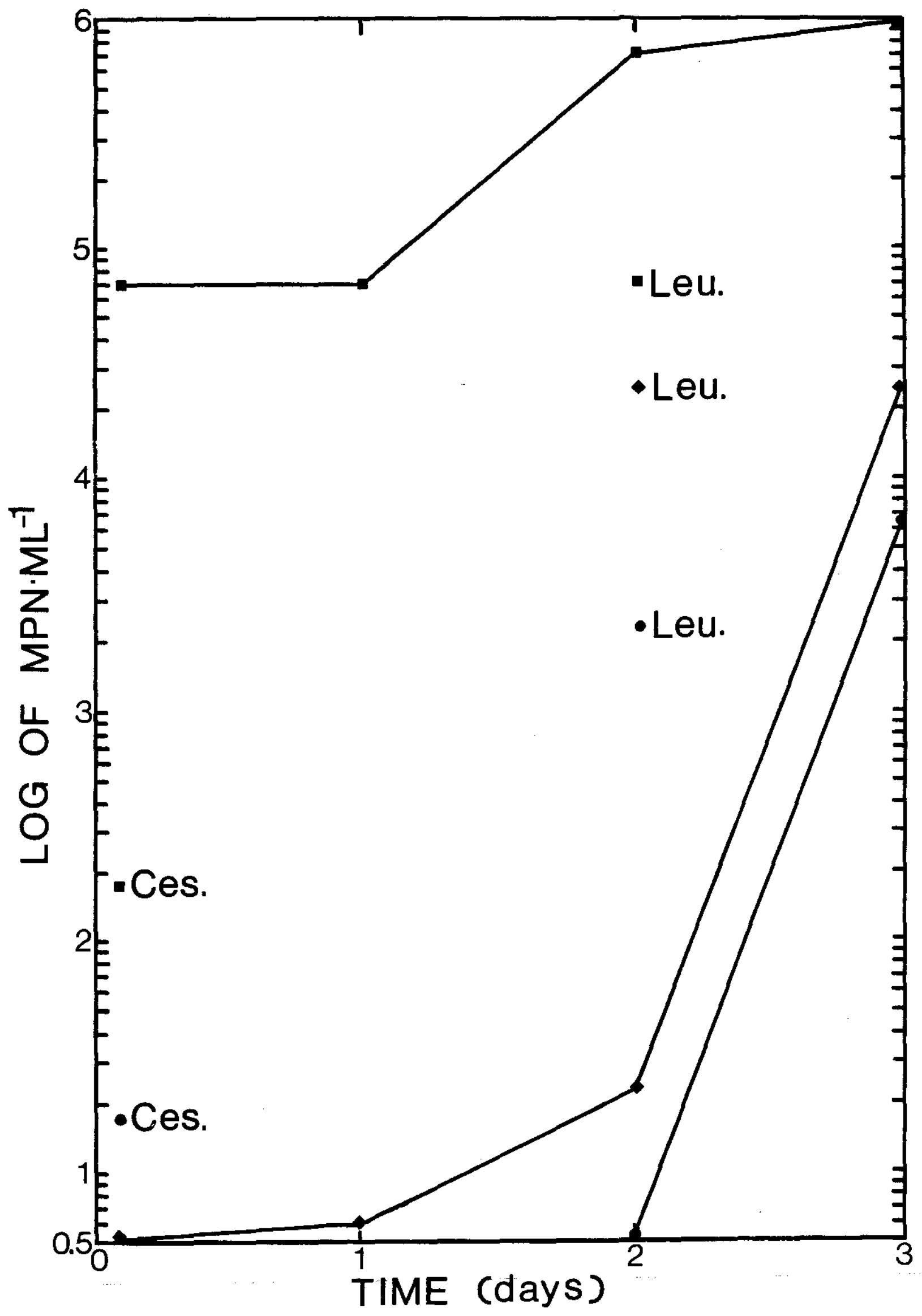


F1gure 2.9. Epifluorescence counts of bacterla and total nanoplankton colonizing discarded appendicularian houses incubated in 41 of unfiltered seawater at $20^{\circ} \mathrm{C}$ in the dark.

(II) Bacter1a

(১) Tnano 


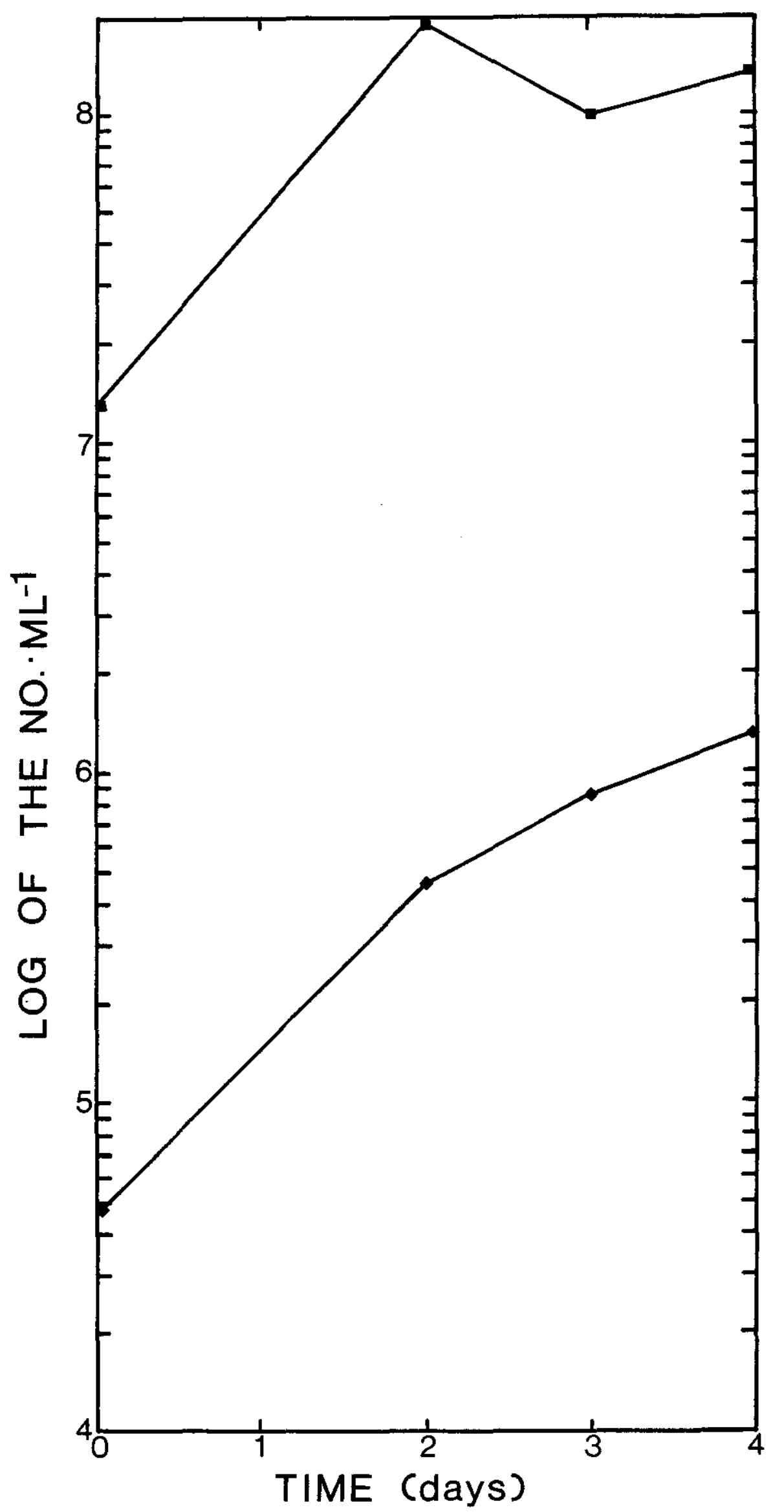


It is probable that the colonization of newly-formed macroaggregates in the field differs from that observed in these simple laboratory experiments. However, these results demonstrate the potential for discarded zooplankton material to develop dense microbial communities similar to those observed in SCUBA-collected aggregates in a relatively short time.

Carbon-to-nitrogen ratios were also measured on macroaggregates and ctenophore mucus (Tables $2.7 \& 2.8$ ). Although the ranges observed for aggregates and mucus overlapped, $\mathrm{C}: \mathrm{N}$ was generally 1 ower for mucus than for aggregates. However, a sample of mucus analyzed after three days of Incubation in unfiltered seawater had a carbon to nitrogen ratio nearly twice that of freshly-released mucus and closer to values for macroaggregates. Macroaggregates and Protozoan Ecology

The large densities of microorganisms observed on macroscopic detrital aggregates in this study presents the possibility of an alternative explanation to the planktonic existence of bacterivorous protozoa. These populations are so enriched on macroaggregates in some cases (Table 2.5) that it is concelvable that all bacterivorous protozoan activity is taking place on these particles, and the populations observed in the surrounding water are largely a result of individuals sloughed from aggregates. This hypothesis seems most plausible with respect to bacterivorous cillates and amoebae. Fenchel (1980) has demonstrated that bacterial density in the open ocean is probably too low to support clllate growth. Culturable bacterivorous clllates in the Control samples of this study and vertical profiles throughout the North Atlantic (Chapter 1) were exceedingly rare. Also, many of the ciliate specles which have been observed thus far on macroaggregates are undescribed species (Small et al., 1983), suggesting that macroaggregates are a unique microenvironment within the plankton. It is possible that bacterivorous cillates rely on relatively long survival times under starvation conditions to 
Table 2.7. Carbon:nitrogen ratios of mucus released by ctenophores held in aquaria.

\begin{tabular}{|c|c|c|}
\hline SPECIES & $\begin{array}{c}\text { NO. OF } \\
\text { SPECIMENS }\end{array}$ & C:N RATIO \\
\hline$\frac{\text { Leucothea }}{\text { multicornis }}$ & 3 & $\begin{array}{l}3.9-4.0 \\
\bar{x}=3.9\end{array}$ \\
\hline$\frac{\text { Cestum }}{\text { veneris }}$ & 2 & $\begin{array}{l}5.4-5.5 \\
\bar{X}=5.4\end{array}$ \\
\hline$\frac{\text { Cestum }}{\text { veneris }}$ & 1 & 9.8 \\
\hline
\end{tabular}

*Incubated at $22^{\circ} \mathrm{C}$ in the dark for 3 days in unfiltered seawater. 
Table 2.8. Carbon:nitrogen ratios of macroaggregates collected from surface water of the North Atlantic.

\begin{tabular}{ccc} 
LOCATION & $\begin{array}{c}\text { NO. OF } \\
\text { AGGREGATES }\end{array}$ & C:N RATIO \\
\cline { 3 - 4 } Continental Shelf & 27 & $\bar{x}^{*}$ \\
Gulf Stream & 23 & $7.6-8.3$ \\
Sargasso Sea & 24 & $\overline{\mathrm{X}}=7.9$ \\
& & $3.6-9.3$ \\
${ }^{*}$ Pooled sample & & $\overline{\mathrm{X}}=6.6$
\end{tabular}


survive in the plankton (Jackson \& Berger, 1984) and that most of their growth takes place in discrete microenvironments. Significant amoebae densities have been observed in the North Atlantic (Davis et a1., 1978), but these protozoa were considered to be associated with particles (from observations of cultures) or with the neuston.

There is also some evidence that the distribution of microflagellates can be explained, in part, by their occurrence on particles (Chapter 4). The association of flagellates with particles is well known (Fenchel, 1982d). Similar results were found in this study (Chapter 4, Figure 4.1). Fenchel (1982d) showed that sieving a water sample through a $20 \mu \mathrm{m}$ screen removed $43 \%$ of the heterotrophic microflagellates.

It is not expected that aggregates can explain the existence of all bacterivorous protozoa in the open ocean. There is ample evidence that some species of microflagellates are well-sulted towards free-living (unattached) existence, and can subsist on relatively low densities of bacteria (Chapter 3; Fenche1, 1982a). However, it has been shown in this dissertation (Chapter 4) that some specles of microflagellates are inefficlent grazers of unattached bacteria but are very efficient at grazing bacteria attached to particles. The distribution of the latter species in the plankton may be strongly affected by the distribution of particles in plankton communties.

The situation described above is shown diagramatically in Figure 2.10. The distance between bacterla (for randomly distributed bacteria) has been plotted versus the density of bacteria. Approximate limits of the benthic, neritic and oceanic environments (based on bacterial density) have been Indicated along a solid line which describes the relationship between bacterial concentration and distance between the bacteria. The hypothesized distributions of bacterivorous cillates, amoebae and flagellates are given according to this relationship. Bacterlvorous cfllates and amoebae are 
Figure 2.10. Log-1og plot of the distance between bacteria (in $\mu \mathrm{m}$ ) as a function of bacterlal density, using the equation adapted from Hamner \& Carleton (1979). 


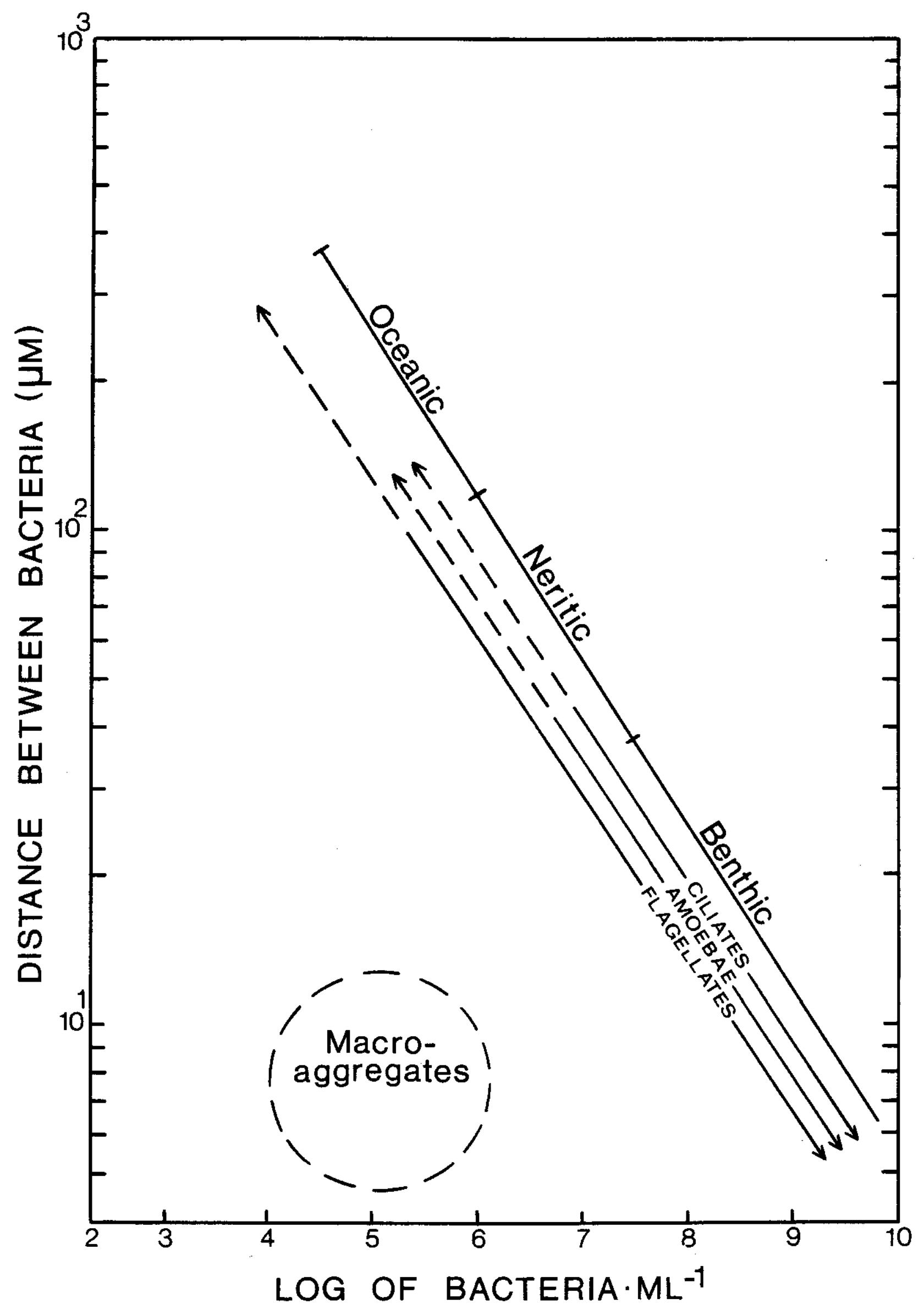


largely benthic organisms, with distributions sometimes extending into neritic waters but rarely into oceanfc waters. Microflagellates are common in benthic and neritic systems, but their activity in the oceanic plankton is still largely conjectural. Distributions proposed in Figure 2.10 are based on the hypothesis that as bacterlal density decreases (and therefore the distance between bacteria increases) protozoa must filter a greater volume of water to obtain the same amount of energy. A point will eventually be reached at which the energetic expense assoclated with feeding activity is greater than the energy obtained by this activity. Fenchel (1980) has used this argument to explain why bacterivorous cillates are largely absent from the open ocean. I propose that macroaggregates alter this view of bacterfvorous protozoan distributions by providing microenvironments of elevated bacterial density in an environment where bacteria are relatively scarce (Figure 2.10) thereby supporting the growth of clliates, amoebae and flagellates which require relatively high bacterlal concentrations. This hypothesis has been verified experimentally by Taylor (1978) who demonstrated that the settling of bacteria in culture flasks containing bacterivorous ciliates created microzones of elevated bacterial density which would support the growth of the ciliates. This view of protozoan ecology suggests that macroaggregates are essentially "islands" of activity in a desert-1ike ocean. Trent et a1. (1978) measured distances between macroaggregates that ranged from 20 to $109 \mathrm{~cm}$. In the open ocean this distance assuredly can be greater. If newly-formed macroaggregates represent "1slands" of food in a desert-1ike environment, the question arises as to how these islands are colonized. It is possible that the chemotactic behavior of protozoa may be valuable for finding these microenvironments. Such behavior has been demonstrated with cultured protozoa (Hauser et al., 1975; Antipa et a1., 1983), but the posstble ecological significance of this behavior remains unknown. Alternatively, the more 
abundant microaggregates may act as "rafting" material to carry microorganisms to and from macroaggregates.

Studies have shown that colonization of artificlal substrata by protozoa follows a similar pattern as the colonization of oceanic islands by larger organlsms (Cairns \& Ruthven, 1970; Yongue \& Calrns, 1978; Henebry \& Cairns, 1980). Both substratum size and distance from colonized substrata were shown to be important factors dictating the colonization of new substrata. If macroaggregates are Indeed "islands" In a desert, then one can expect that particle size and distance from other particles will have 1mportant implications for protozoan assemblages appearing on the aggregates.

It is difficult to assess the overall importance of aggregates as an explanation for the planktonic existence of protozoa without accurate estimates of the densities of aggregates in the plankton. However, this is a difficult task because of the continuous spectrum of aggregate sizes from a few micrometers to tens of centimeters. There is, at present, no technique for enumerating the full range of particles in an environment and simultaneously determining what proportion of these particles contain microbial populations. Even the smallest microscopic particles can support microbial populations (Pomeroy, 1983; Chapter 4, Figure 4.1). Therefore, 1t is not yet possible to accurately estimate the importance of growth on aggregates as an explanation for the planktonic existence of protozoa. Macroaggregate densities were not estimated in this study. Rather, the importance of microorganisms on a per-particle basis was examined. Without estimates of the macro- and microaggregate density it is not possible to determine the absolute importance of particle-associated protozoa relative to free-living microorganisms.

Other Microenvironments of Plankton Communities

This study has addressed the potential of macroscopic detrital communities 
to serve as concentration points for microblal populations. However, several other microcommunitles exist in plankton communities which also contain mixed assemblages of phototrophic and heterotrophic microorganisms. Several algal aggregates are known to contain heterotrophic microorganisms. Rhizosolenia mats (Carpenter et al., 1977; Alldredge \& Silver, 1982) were sampled in the Sargasso Sea during this study (Table 2.9). Like marlne snow, they contained highly enriched populations of bacteria and protozoa. The high C:N ratio for these mats observed by Carpenter et al. (1977) might be explained by these heterotrophs. Thalasslosira parthenela colonies (Elbrachter \& Boje, 1978) have also been described (and confirmed during this study) as a complex assoclation of the diatom, bacteria, heterotrophlc flagellates (predominantly dinoflagellates) and clliates. Both of these aggregate types can be abundant in the surface waters of the open ocean.

Other types of microenvironments also exist. For example, the neuston can contain elevated concentrations of dissolved organic matter and microorganisms (Norris, 1965; Sieburth et a1., 1976; Davis et a1., 1978). In addition, a number of microblal associations have been described from the pelagic environment in which nutrient and energy transfer between the participants are tightly coupled both temporally and spatially (Silver et al., 1983).

Macroaggregates are one of many types of microenvironments in the plankton which are characterized by dense assemblages of phototrophic and heterotrophic microorganisms. Realization of the importance of these microenvironments in the overall function of plankton communities is changing our view of how we perceive plankton communities. The paradigm that the ocean is a dilute homogeneous environment characterized by slow-growing organisms has been questioned (Goldman, in press a \& b). It may be replaced by one in which the ocean is a heterogeneous environment composed of discrete microenvironments inhabited by relatively fast-growing organisms. 
Table 2.9. Average population densities and enrichment factors (density in aggregates vs. density in the surrounding water) for two Rhizosolenia mats collected in the Sargasso Sea, 8/28/81. Concentration factors for each populations are given in parentheses below the density.

\begin{tabular}{|c|c|}
\hline \multicolumn{2}{|c|}{ EPIFLUORESCENCE COUNTS } \\
\hline $\begin{array}{r}\text { HPICO } \\
\times 10^{6} \mathrm{ml}^{-1} \\
\end{array}$ & $\begin{array}{c}\text { TOTAL } \\
\text { NANOPIANKTON } \\
\times 10^{4} \mathrm{~m}^{-1} \\
\end{array}$ \\
\hline 10.7 & 15.7 \\
\hline$(34.9)$ & (114) \\
\hline
\end{tabular}

\begin{tabular}{|c|c|c|}
\hline \multicolumn{3}{|c|}{ MPN $M^{-1}$} \\
\hline CILIATES & FLAGELLATES & AMOEBAE \\
\hline 6 & 3220 & 120 \\
\hline$(-)$ & $(55,600)$ & $(2,060)$ \\
\hline
\end{tabular}




\section{REFERENCES}

Alldredge, A.L. 1972. Abandoned larvacean houses: A unique food source in the pelagic environment. Science 177: 885-887.

Alldredge, A.L. 1976. Discarded appendicularian houses as sources of food, surface habitats, and particulate organic matter in planktonic environments. Limnol. Oceanogr. 21: 14-23.

Alldredge, A.L. 1979. The chemical composition of macroscopic aggregates in two neritic seas. Limnol. Oceanogr. 24: 855-866.

Alldredge, A.L. \& J.L. Cox. 1982. Primary productivity and chemical composition of marine snow in surface waters of the Southern California Bight. J. Mar. Res. 40: 517-527.

Alldredge, A.L. \& M.W. S1lver. 1982. Abundance and production rates of floating diatom mats (Rhizosolenia castracanel and R. 1mbricata var. shrubsole1) in the Eastern Pacific Ocean. Mar. Biol. 66: 83-88. Antipa, G.A., K. Martin \& M.T. Rintz. 1983. A note on the possible ecological significance of chemotaxis in certain cillated protozoa. J. Protozool. 30: 55-57.

Barham, E.G. 1979. Giant larvacean houses: Observation from deep submersibles. Sclence 205: 1129-1131.

Baylor, E.R. \& W.H. Sutcliffe, Jr. 1963. Dissolved organic matter in seawater as a source of particulate food. Limnol. Oceanogr. 8: 369-371. Bothner, M.H., C.M. Parmenter \& J.D. M11liman. 1981. Temporal and spatial variations in suspended matter in Continental Shelf and Slope waters off the north-eastern United States. Est. Coast. Shelf Sc1. 13: 213-234. Cairns, J. Jr. \& J.A. Ruthven. 1970. Artificial microhabitat size and the number of colonizing species. Trans. Amer. Micros. Soc. 89: 100-109. Caron, D.A., P.G. Davis, L.P. Madin \& J.McN. Sleburth. 1982. Heterotrophic bacterla and bacterfvorous protozoa in oceanic macroaggregates. Science 
218: $795-797$.

Carpenter, E.J., G.R. Harbison, L.P. Madin, N.R. Swanberg, D.C. Biggs, E.M. Hulbert, V.L. McAllister \& J.J. McCarthy. 1977. Rhizosolenia mats. Limno1. Oceanogr. 22: 739-741.

Coles, S.L. \& R. Strathmann. 1973. Observations on coral mucus "flocs" and their potential trophic significance. Limnol. Oceanogr. 18: 673-678. Davis, P.G., D.A. Caron \& J.McN. Sleburth. 1978. Oceanic amoebae from the North Atlantic: Culture, distribution, and taxonomy. Trans. Amer. Micros. Soc. 97: 73-88.

Davo11, P.J. 1983. Life history and community structure of marine snow aggregates from Monterey Bay. EOS, Trans. Amer. Geophys. Union 64: 1020 (Abstr.).

Ducklow, H.W. \& R. Mitche11. 1979. Bacterlal populations and adaptations in the mucus layers on living corals. Limnol. Oceanogr. 24: 715-725.

Elbrachter, M. \& R. Boje. 1978. On the ecological significance of Thalassiosira parthenela in the North-west African upweling area. In: Boje, R. \& M. Tomczak (eds.), Upwelling ecosystems, Springer-Verlag, Ber1in, p 24-31.

Fenche1, T. 1980. Suspension feeding in c1llated protozoa: Feeding rates and their ecological significance. Microb. Ecol. 6: 13-25.

Fenche1, T. 1982a. Ecology of heterotrophic microflagellates. I. Sone Important forms and their functional morphology. Mar. Ecol. Prog. Ser. 8: 211-223.

Fenchel, T. 1982b. Ecology of heterotrophic microflagellates. IV. Quantitative occurrence and importance as bacterlal consumers. Mar. Ecol. Prog. Ser. 9: 35-42.

Gerber, R.P. \& N. Marshall. 1974. Ingestion of detritus by the lagoon pelagic community at Enfwetol Ato11. Limnol. Oceanogr. 19: 815-824. 
Gerber, R.P. \& N. Marsha11. 1982. Characterization of the suspended particulate organic matter and feeding by the lagoon zooplankton at Enlwetok Atoll. Bull. Mar. Sci. 32: 290-300.

Gilmer, R.W. 1972. Free-floating mucus webs: A novel feeding adaptation for the open ocean. Sclence 176: 1239-1240.

Goldman,J.C. In press. Oceanic nutrient cycles. In: Fasham, M.J. (ed.).

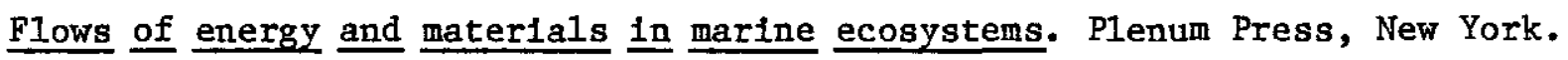
Goldman, J.C. In press. Conceptual role for microaggregates in pelagic waters. Bull. Mar. Sci.

Gordon, D.C.Jr. 1970. A Microscopic study of organic particles in the North Atlantic. Deep-Sea Res. 17: 175-185.

Gottfried, M. \& M.R. Roman. 1983. Ingestion and incorporation of coral-mucus detritus by reef zooplankton. Mar. Biol. 72: 211-218.

Hamner, W.H. \& J.H. Carleton. 1979. Copepod swarms: Attributes and role in coral reef ecosystems. Limnol. Oceanogr. 24: 1-14.

Hauser, D.C.R., M. Levandowsky, S.H. Hutner, L. Chunosoff \& J.S. Hollwitz. 1975. Chemosensory responses by the heterotrophic marine dinoflagellate Crypthecodinium cohn11. Microb. Ecol. 1: 246-254.

Henebry, M.S. \& J. Calrns Jr. 1980. The effect of island size, distance and epicenter maturity on colonization in freshwater protozoan communities. Amer. Mid. Nat. 104: 80-92.

Honjo, S. \& V. Asper. 1982. Deep water marine snow concentrations in two oceans. EOS, Trans. Amer. Geophys. Union 63: 1016 (Abstr.).

Honjo, S., K.W. Doherty, Y.C. Agrawal \& V.L. Asper. 1984. Direct optical assessment of large amorphous aggregates (marine snow) in the deep ocean. Deep-Sea Res. 31: 67-76.

Jackson, K.M. \& J. Berger. 1984. Survival of cillate protozoa under starvation conditions and at low bacterlal levels. Microb. Ecol. 10: 
47-59.

Johannes, R.E. 1967. Ecology of organic aggregates in the vicinity of a coral reef. Limnol. Oceanogr. 12: 189-195.

Johnson, B.D. \& R.C. Cooke. 1980. Organic particle and aggregate formation resulting from the dissolution of bubbles in seawater. Limnol. Oceanogr. 25: $653-661$.

Johnson, P.W., H. Xu \& J.McN. Sieburth. 1982. The utilization of chroococcoid cyanobacteria by marine protozooplankters but not by calanoid copepods. Ann. Inst. oceanogr., Parls 58(S): 297-308.

Kimor, B. 1981. The role of phagotrophic dinoflagellates in marine ecosystems. Kieler Meeresforsch. 5: 164-173.

Klmor, B., F.M.H. Reid \& J.B. Jordan. 1978. An unusual occurrence of Hemiaulus membranaceus Cleve (Bacillariophyceae) with Richelia intracellularis Schmidt (Cyanophyceae) off the coast of Southern California in October 1976. Phycologia 17: 162-166.

Knauer, G.A., D. Hebel \& F. Cipriano. 1982. Marine snow: Major site of primary production in coastal waters. Nature 300:630-631.

Kopylov, A.I., A.F. Pasternak \& Y.V. Moiseyev. 1981. Consumption of zooflagellates by planktonic organisms. Oceanol. 21: 269-271.

Lighthart, B. 1969. Planktonic and benthic bacterivorous protozoa at eleven stations in Puget Sound and adjacent Pacific Ocean. J. Fish. Res. Bd. Canada 26: 299-304.

Linley, E.A.S. \& J.G. Field. 1982. The nature and ecological significance of bacterial aggregation in a nearshore upwelling ecosystem. Est. Coast. Shelf Sci. 14: 1-11.

Morey-Galnes, G. In press. Heterotrophic nutrition. In: Taylor, F.J.R. (ed.). The biology of dinoflagellates.

Norris, R.E. 1965. Neustonic marine Craspedomonadales (Choanoflagellates) 
from Washington and California. J. Protozool. 12: 589-602.

Pomeroy, L.R. 1983. Origin and distribution of flocculent aggregates. EOS,

Trans. Amer. Geophys. Union 64: 1020 (Abstr.).

Pomeroy \& Delbel. 1980. Aggregation of organic matter by pelagic tunicates. Limnol. Oceanogr. 25: 643-652.

Prezelin, B.B. \& A.L. Alldredge. 1983. Primary production of marine snow during and after an upwelling event. Limol. Oceanogr. 28: 1156-1167.

Riley, G.A. 1970. Organic aggregates in seawater and the dynamics of their formation and utilization. Limnol. Oceanogr. 8: 372-381.

Riley, G.A., D. VanHemert \& P.J. Wangersky. 1965. Organic aggregates in surface and deep waters of the Sargasso Sea. IImnol. Oceanogr. 10: 354-363.

Shanks, A.L. \& J.D. Trent. 1979. Marine snow: Microscale nutrient patches. Limnol. Oceanogr. 24: 850-854.

Shanks, A.L. \& J.D. Trent. 1980. Marine snow: Sinking rates and potential role in vertical flux. Deep-Sea Res. 27A: 137-143.

Sieburth, J.McN., P-J. Willis, K.M. Johnson, C.M. Burney, D.M. Lavoie, K.R. Hinga, D.A. Caron, F.W. French III, P.W. Johnson \& P.G. Davis. 1976. Dissolved organic matter and heterotrophic microneuston in the surface microlayers of the North Atlantic. Sclence 194: 1415-1418.

Silver, M.W. \& A.L. Alldredge. 1981. Bathypelagic marlne snow: Deep-sea algal and detrital community. J. Mar. Res. 39: 501-530.

Silver, M.W., M.M. Gowing, D.C. Brownlee \& J.0. Corliss. 1984. Ciliated protozoa associated with oceanic sinking detritus. Nature 309: 246-248. Silver, M.W., M.M. Gowing, D.L. Garrison, P.J. Davoll, R.L. Pinto \& A.F. Michaels. 1983. Cryptic mlcrohabitats supporting microbial food webs in the pelagic zone. EOS, Trans. Amer. Geophys. Union 64: 1020 (Abstr.). Silver, M.W., A.L. Shanks \& J.D. Trent. 1978. Marine snow: Microplankton 
habitat and source of small-scale patchiness in pelagic populations. ScIence 201: 371-373.

Smal1, E.B., B. Neun, D. Caron \& P. Davis. 1983. Clllates associated with Gulf Stream "snow". J. Protozool. 30: 15A (Abstr.).

Taylor, F.J.R. 1982. Symbloses in marine microplankton. Ann. Inst. oceanogr., Paris 58(S): 37-66.

Taylor, W.D. 1978. Growth responses of cilfate protozoa to the abundance of their bacterial prey. Microb. Ecol. 4: 207-214.

Trent, J.D., A.L. Shanks \& M.W. Silver. 1978. In s1tu and laboratory measurements of macroscoplc aggregates in Monterey Bay, California. Limno1. Oceanogr. 23: 626-635.

Yongue, W.H.Jr. \& J. Cairns Jr. 1978. The role of flagellates in pioneer protozoan colonization of artificlal substrates. Pol. Arch. Hydrobiol. 25: 787-801. 
CHAPTER 3

GROWTH OF HETEROTROPHIC MICROFLAGEJ_LATES

IN BATCH AND CONTINUOUS CULTURE AND ITS IMPLICATIONS

FOR THEIR PLANKTONIC EXISTENCE 


\section{ABSTRACT}

The growth characteristics of three species of bacterivorous (bacterla-eating) heterotrophic microflagellates were examined in batch and continuous culture. Monas sp. 1 was fed two species of heterotrophic bacteria and two specles of chroococcold cyanobacterla to test their effect on the growth rate of the microflagellate. The growth rate of the microflagellate was high (doubling times $=6.9-9.6 \mathrm{hr}$ ) on three of the food types, but was significantly depressed on one of the specles of cyanobacterla (doubling time $=43 \mathrm{hr})$. Ce11 yleld was higher when the microflagellate was fed heterotrophic bacteria than when it was fed cyanobacterla. Growth parameters of Monas sp. 2 and Cryptobla maris were determined in batch and continuous culture. Batch culture was used to establish the maximum growth rate ( $U_{m}$ ) and cell yield at $U_{m}$. The microflagellates were then grown at rates less than $U_{m}$ in continuous culture using a static bacterial population to achieve steady state conditions. The cell yields, half-saturation constants, Ingestion rates and clearance rates of the two microflagellates were calculated at $U<U_{m}$ based on $U_{m}$ (determined in batch culture) and bacterlal and protozoan densities at steady state in the continuous culture vesse1s.

Growth rates of the microflagellates were remarkably plastic. Microflagellate growth was sustained in the continuous culture vessel at $6 \%$ and $7 \%$ of $\mathrm{U}_{\mathrm{m}}$ for Monas sp. 2 and Cryptobia maris, respectively. These growth rates corresponded to ingestion rates of 1-2 bacteria flagellate ${ }^{-1}$ $\mathrm{hr}^{-1}$. Cell yields of the two microflagellates growing at $\mathrm{U}<$ $\mathrm{U}_{\mathrm{m}}$ were comparable to cell yields for the microflagellates growing at $\mathrm{U}_{\mathrm{m}}$, suggesting that the maintenance energy required by these microorganisms was a small fraction of their total energy budget. Maximum ingestion rates were calculated to be 18 and 5 bacteria flagellate ${ }^{-1} \mathrm{hr}^{-1}$ for Monas sp. 2 and 
bacteria that will support a growth rate equal to $\left.(1 / 2) U_{m}\right)$ of $1 \times 10^{6}$ bacterla $\mathrm{ml}^{-1}$ was observed for Monas sp. 2, suggesting that this species could grow on in-situ densities of bacterioplankton. Cryptobia had a Iower affinity for bacterioplankton $\left(\mathrm{K}_{\mathrm{s}}=5 \times 10^{6}\right.$ bacteria $\left.\mathrm{m} 1^{-1}\right)$. A competition experiment between Cryptobla and Monas sp. 2 conducted at a relatively slow growth rate $\left(0.28\right.$ day $^{-1}$ ) in continuous culture confirmed the prediction that Monas would outcompete Cryptobia when competing for bacterlal food. The results of this study support the hypothesis that heterotrophic microflagellates may be Important consumers of bacteria in plankton communities. 


\section{INTRODUCTION}

Aquatic bacteria possess the ability to grow very rapidly under favorable conditions. Despite this large potential for growth, it has been noted that the density of free-11ving, unattached bacterla in the plankton generally varies between relatively narrow limits (Ferguson \& Rublee, 1976; Watson et al., 1977; Ramsay, 1978). Two contradictory hypotheses can be proposed to explain this apparent inconsistency. Bacterial density will remain unchanged if the bacteria are not growing. In support of this notion, dormancy has been proposed as a common feature of the bacterioplankton (Stevenson, 1978) but contemporary views have challenged this hypothesis (Azam et al., 1983). Another way of malntaining an unchanging bacterial density is to quickly remove bacterial production by grazing. This latter hypothesis has received considerable attention in recent years and protozoa, primarily ciliates and heterotrophic microflagellates, have been the primary focus of this attention.

Numerous protozoan specles have a well-documented ability for bacterivory and have been repeatedly isolated from the plankton. However, these characteristics alone do not indicate that bacterivorous protozoa control bacterial density in the plankton. Organisms capable of performing this role must be ublquitous in the plankton, be able to respond rapidly to increases in bacterlal number, and yet be able to withstand short perlods of starvation. In addition, they must be capable of grazing bacterla down to relatively low densities while maintalning their own growth on those low densities.

Experimental evidence and field observations suggest that heterotrophic microflagellates may meet these criteria while it appears that bacterivorous ciliates and amoebae do not. Distribution studies have indicated that heterotrophic microflagellates are ubiquitous in plankton communities (Chapter 1; Davis \& S1eburth, 1982; Fenche1, 1982d; Caron, 1983; Sherr et a1., 1984; Davis et al., submitted) while relatively low densities of bacterivorous 
clilates and amoebae have been observed in the plankton (Chapter 1). In addition, experimental studies have indicated that greater densities of bacterla then are normally present in the plankton are required in order to maintain the growth of clllates (Berk et al., 1976; Taylor, 1978; Fenchel, 1980b). Clllated protozoa have been shown to have definite feeding "thresholds" of bacterlal density below which feeding activity does not take place (Salt, 1967; Hamiliton \& Preslan, 1970; Berk et al., 1976; Fenche1, 1980a). Threshold values obtained for laboratory experiments with cillates $\left(10^{6}-10^{7}\right.$ bacteria $\left.\mathrm{ml}^{-1}\right)$ have generally been higher than densities of bacteria in most oceanic plankton communitles. Fenchel (1980b) argued that at low bacterial densities (1.e. densities comparable to those found in-situ) the energy which clilates obtained from the bacterla filtered from the water was not enough to meet the metabolic costs of the filtering activity. In contrast, the information that is presently available for microflagellates suggests that these thresholds may not exist, or may be lower than in-situ densities of bacteria. Therefore, bacterivorous ciliates and amoebae may be important in controlling bacterial populations in benthic ecosystems (Fenchel, 1967) and on organically enriched particulate material in the plankton (Caron et a1., 1982; S1lver et al., 1982, 1984), but they are probably not the primary grazers of free-living bacteria in the plankton.

The ability of bacterfvorous microflagellates to control bacterial densities in plankton communities is predicated on their ability to feed on relatively low densities of bacteria. The experimental data which are presently avallable concerning the ability of microflagellates to graze low bacterial densities have been obtained with batch cultures of microflagellates. Batch culture is useful for determining the maximum specific growth rate $\left(U_{m}\right)$ and cell yield $(Y)$. Food (bacteria) is offered to the microflagellate at a density sufficient to allow the maximum rate of 
ingestion (i.e. in excess). The exponential increase in the density of the microflagellate is then used to calculate $\mathrm{U}_{\mathrm{m}^{*}}$ Cell yield is calculated by dividing the total microflagellate biomass produced by the bacterlal biomass consumed once the food has been exhausted.

Batch culture has also been used to measure the growth rates of microflagellates when food is not in excess. Under these conditions ( $U<$ $\left.U_{m}\right)$ it has been demonstrated that the specific growth rate of the microflagellates was dependent on the density of bacteria, and could be described by the empirical equation of Monod (1949),

$$
\mathrm{U}=\mathrm{U}_{\mathrm{m}} \frac{\mathrm{s}}{\left(\mathrm{s}+\mathrm{K}_{\mathrm{s}}\right)}
$$

where $U$ and $U_{m}$ are the specific growth rate and the maximum specific growth rate, respectively, $s$ is the bacterlal concentration, and $K_{s}$ is the half-saturation constant (1.e. the density of bacteria at which $U=$ $(1 / 2) \mathrm{U}_{\mathrm{m}}$. The half-saturation constant presumably provides an indication of the affinity of the microflagellate for the bacteria (1.e. an indication of its ability to grow at low bacterlal density). Fenchel (1982b) has demonstrated the applicability of the Monod equation for describing the growth of several bacterivorous microflagellates.

Experiments where the growth rate is less than $U_{m}$ are difficult to perform, however, since they can only be conducted for a short perlod of time at low densities of microflagellates. These restrictions are necessary to prevent a reduction in the bacterial density due to grazing and thereby a change in the growth rate of the microflagellate. Because of these limitations it is not possible to obtain information directly on ingestion rate, cell yleld or clearance rate, which in practice are calculated by changes in the density of bacteria in the culture vesse1. Also, because of the short duration of the experiments, it is not possible to test the ability 
of the microflagellates to grow for prolonged period at $U<U_{m}$.

An alternative method of Investigating the growth parameters of

microflagellates at growth rates less than $U_{\mathrm{m}}$ is continuous culture. If the bacterial population used as food is static (1.e. non-growing) and is the one factor limiting growth of the microflagellates, then the growth of the protozoa can be described according to the equations defining the growth of bacterla in a chemostat (Herbert et al., 1956). Under these conditions the density of bacterla and microflagellates should approach and maintain a steady state. The steady state densities are described by the equation

$$
\mathrm{D}=\mathrm{U}_{\mathrm{m}} \frac{\overline{\mathbf{s}}}{\left(\overline{\mathbf{s}}+\overline{\mathrm{K}}_{\mathrm{s}}\right)}
$$

which can be rearranged to give

$$
\overline{\mathbf{s}}=\frac{\mathrm{K}_{\mathrm{g}}(\mathrm{D})}{\left(\mathrm{U}_{\mathrm{m}}-\mathrm{D}\right)}
$$

and by the equation

$$
Y=\frac{\bar{x}}{S_{r}-\bar{s}}
$$

which can be rearranged to give

$$
\overline{\mathbf{x}}=\mathrm{Y}\left(\mathrm{S}_{\mathrm{r}}-\overline{\mathrm{s}}\right)
$$

where $D$ is the dilution rate of the culture vessel, $S_{r}$ is the density of substrate in the reservoir (1.e. static bacterlal population), $\overline{\mathbf{s}}$ and $\bar{x}$ are the density of bacteria and protozoa in the culture vessel at steady state, respectively, and the other parameters are as previously defined. Equation 1 differs from equation 2 only in the substitution of $D$ for $U$. At steady state the rate of change of the density of microflagellates in the culture vessel is zero and thus $U$ must equal $D$. It is therefore possible to hold the growth rate of the microflagellate constant at any rate $U<U_{m}$ providing there is no feeding "threshold" as previously discussed for clilates. Since $D$ and $\overline{\mathrm{s}}$ in equation 2 are directly measurable at steady state and $U_{m}$ can be determined 
from batch culture, $K_{s}$ can be calculated from equation 2 . Cell yield can be calculated from equation 4 since $\overline{\mathbf{x}}, \overline{\mathbf{s}}$ and $\mathrm{S}_{\mathrm{r}}$ are also directly measurable. Cell yield can also be determined in batch culture for microflagellates growing at $U_{m}$ and compared to $Y$ obtained at $U<U_{m^{*}}$ In addition, it is possible to directly measure the ingestion rate (I) of the microflagellates at $\mathrm{U}<\mathrm{U}_{\mathrm{m}}$ under steady state conditions (bacteria consumed flagellate ${ }^{-1}$ $\mathrm{hr}^{-1}$ ) according to the equation

$$
I=\frac{\left(S_{r}-\bar{s}\right)(D)}{\bar{x}}
$$

and to measure the clearance rate ( $F)$ ( $\mathrm{ml}$ flagellate $\mathrm{hr}^{-1} \mathrm{hr}^{-1}$ ) according to the equation

$$
F=\frac{I}{\bar{s}}
$$

Continuous culture also allows for the growth of the microflagellates at $\mathrm{U}<$ $\mathrm{U}_{\mathrm{m}}$ for a prolonged period, thus avolding "acclimatization" problems with short-term batch culture experiments.

The feasibility of the application of continuous culture techniques for culturing bacterivorous clllates has been amply tested (see reviews by Curds \& Bazin (1977) and Legner (1980)). While most of these Investigations have been performed with a growing bacterlal population, Hamilton and Preslan (1970) demonstrated that a static bacterial population could be used to grow the clliate Uronema sp. at steady state. Despite the proven utility of continuous culture for protozoa and 1ts potential for investigating growth parameters at $\mathrm{U}<\mathrm{U}_{\mathrm{m}}$, attempts have not yet been made to grow bacterivorous microflagellates in continuous culture with a similar experimental design.

The growth parameters of cultured species of heterotrophic mfcroflagellates were examined in batch and continuous culture. Batch culture was used to test the acceptability of four food species and to measure $U_{m}$ and $\mathrm{Y}$ for species to be grown in continuous culture. Two species of 
microflagellates were then grown in continuous culture at relatively slow growth rates using a static population of the bacterium Pseudomonas halodurans. Population densities of bacteria and microflagellates at steady state were determined and used to calculate varlous growth parameters Including cell yields, half-saturation constants, ingestion rates and clearance rates. The results support the recent contention that heterotrophic microflagellates may be the most important grazers of bacteria in plankton communities. 
METHODS AND MATERIALS

Experiments were carried out in batch and continuous culture with two unidentified species of Monas and with Cryptobia maris. Monas sp. 1 (clone \#5/80-7) was isolated from Slope Water at the outer edge of the Continental Shelf off Cape Cod, Massachusetts. It is a roughly spherical cell, 3.0-4.5 $\mathrm{mm}$ in diameter, with an average volume of $33.5 \mathrm{\mu m}^{3}$. Monas sp. 2 (clone \#2/80-2) and Cyptobia marls were 1solated from surface waters of Buzzards Bay, Massachusetts. Monas sp. 2 is similar in size, shape and volume to Monas sp. 1. The presence or absence of body scales was not determined with electron microscopy and therefore it is possible that these species belong to the genus Paraphysomonas (Hibberd, 1979). Cryptobia is a teardrop-shaped ce11, 3.5-4.5 $\mu \mathrm{m} \times 5.5-6.5 \mu \mathrm{m}$ in size, with an average volume of $41.9 \mu^{3}$. Clonal cultures of all species were started by micropipetting individual microflagellates from enrichment cultures prepared by adding sterile rice grains to seawater samples. Clones were malntalned on a mixed bacterlal population enriched by periodic transfers to sterile natural seawater with $0.01 \%$ yeast extract. Batch Culture Experiments:

Two experlments were carrled out in batch culture. Monas sp.1 was used in the first experiment to test the effect of four types of food on the growth rate and cell yield of the microflagellate. Two spectes of heterotrophic bacteria (Pseudomonas halodurans and Serratia marinorubra) and two species of chroococcold cyanobacteria (Synechococcus Strain WH 7803) and Synechococcus

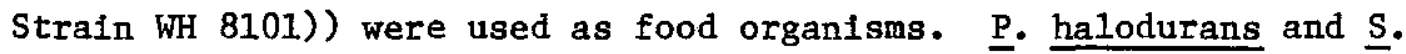
marinorubra are rod-shaped species with average cell volumes of $0.72 \mathrm{\mu m}^{3}$ and $0.79 \mu^{3}$, respectively. The Synechococcus species are also rod-shaped organisms with average cell volumes of $1.14 \mu^{3}$ (clone WH 7803) and 1.04

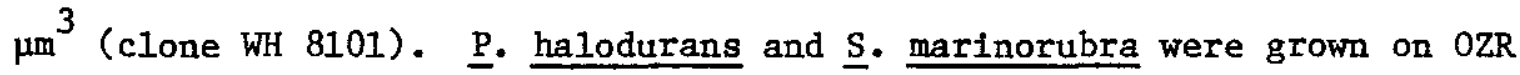


broth until late exponential phase, centrifuged at $5000 \mathrm{rpm}$ for 10 minutes, and then resuspended in natural filter-sterilized seawater without nutrients. The resuspended cells were then passed through a $5 \mu \mathrm{m}$ pore size Nuclepore fllter to break up clumped cells. The cyanobacterla were grown in $\mathrm{S} / \mathrm{N}$ media (J.B. Waterbury, pers. comm.) and sampled during the exponential growth phase. They were centrifuged, resuspended, and filtered as for the heterotrophic bacteria. The experiment was carried out with $500 \mathrm{~m} 1$ of each suspension in unshaken Fernbach flasks in continuous darkness at $20^{\circ} \mathrm{C}$ $\pm 1^{\circ}$. Each flask was thoroughly mixed prior to sampling. Samples were preserved with glutaraldehyde at a final concentration of $1 \%$. Densities of the food spectes and the microflagellate were determined by epifluorescence microscopy using acridine orange (Watson et al., 1977; Davis \& Sieburth, 1982). The maximum specific growth rate $\left(U_{m}\right)$ of the microflagellate fed each type of food was determined by least squares regression of the linear portion of the growth curves. The cell yleld ( $\mathrm{Y}=$ microflagellate biomass produced per unit of bacterial biomass consumed) for each food was calculated as the total blovolume of microflagellates produced (density $\mathbf{x}$ average volume $\operatorname{cell}^{-1}$ ) divided by the biovolume of the bacteria consumed.

The second batch culture experiment was performed to determine $U_{m}$ and cell yield ( $Y$ ) of Monas sp. 2 and Cryptobia maris using $\underline{P}$. halodurans as food. The bacterium was grown for $24 \mathrm{hr}$ on $50 \mathrm{mg} 1^{-1}$ of yeast extract in natural seawater and then $30 \mathrm{mg} 1^{-1}$ of streptomycin and $60 \mathrm{mg} 1^{-1}$ of peniclilin were added. Antibiotics were added to maintain consistency with the continuous culture procedures (see below). The experiment was conducted in Fernbachs at $25^{\circ} \mathrm{C} \pm 0.5^{\circ}$ in continuous darkness. The flasks were stirred continuously with a magnetic stirrer. Samples were preserved and counted as in the previous experiment. Growth rates and cell yields of the two microflagellates were calculated from the growth curves. 
Continuous Culture Experiments:

Continuous culture experiments were also carried out with Monas sp. 2 and Cryptobia maris. These experiments were modelled after the experiments of Hamilton \& Preslan (1970) in which a static (non-growing) bacterial population was used to grow the ciliate Uronema sp.. The use of a static bacterial population allowed the system to reach steady state, thus avoiding oscillations in the density of predators and prey which usually characterize systems where bacterial growth is not prevented (Curds, 1971; Curds \& Bazin, 1977). The continuous culture apparatus used for these experiments is shown in Figure 3.1. The bacterium Pseudomonas halodurans was grown for $24 \mathrm{hr}$ on 50 mg $1^{-1}$ yeast extract in natural seawater. Antibiotics were then added ( 30 mg $1^{-1}$ of streptomycin and $60 \mathrm{mg} \mathrm{I}^{-1}$ of penicililn) to stop bacterial growth, and the bacterlal reservolr was placed in a water bath at $5^{\circ} \mathrm{C}$. Antibiotics were used to prevent cryptic growth of the bacterium in the protozoan culture vessel. This procedure has been successively used by Hamilton \& Preslan (1970). Eplfluorescence counts of bacteria in the bacterial reservoir in this study did not vary over the course of an experiment. However, the average volume of $\underline{\mathrm{P}}$. halodurans decreased slightly with time, presumably due to respiration. The change in average volume was recorded for the calculation of cell yields. The bacterial suspension was pumped into a $500 \mathrm{~m} 1$ culture vessel containing the microflagellates with a peristaltic pump and the vessel was continuously mixed by bubbling with filter-sterilized air and with a magnetic stirrer. The culture was assumed to be at steady state when successive samples taken over a period Ionger than the turnover time of the vessel showed no significant difference in the density of the bacterium or microflagellate.

Experiments were carrled out at three dilution rates for each of the two microflagellate species. The density of the microflagellates and the 
$-114-$

Figure 3.1. Continuous culture apparatus used to grow the microflagellates Monas sp. 2 and Cryptobla marls. Pseudomonas halodurans was used as the static bacterial population. 


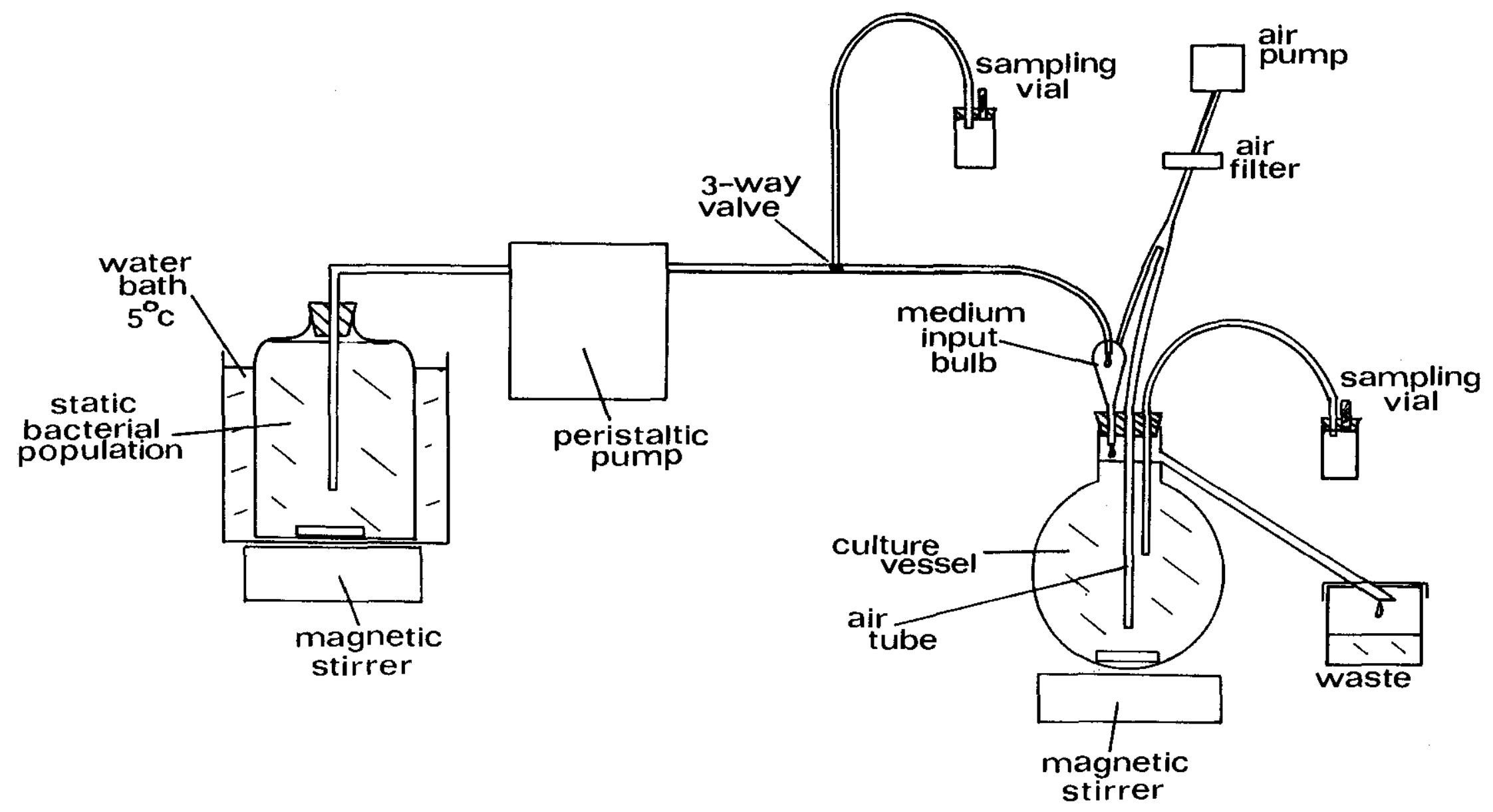


bacterium were monftored until the vessels reached steady state. The densities of both populations at steady state were then used to calculate the cell yield $(Y)$ according to equation 4 , the half saturation constant ( $K_{s}$ ) according to equation 2, the ingestion rate per flagellate per unit time (I) according to equation 6 , and the clearance rate per flagellate per unit time (F) according to equation 7. 


\section{RESULTS AND DISCUSSION}

Effect of Food Type on Growth Rate:

The results of the batch culture experiment to determine the effect of four food types on the growth of Monas sp. 1 (Figure 3.2 and Table 3.1) Indicate that food species greatly affected the growth of this microflagellate. A11 four food specles supported the growth of Monas, but the doubling time of the microflagellate varled by a factor of 6.2 and cell yield varied by a factor of 9.7. Numerous studles have shown that food quality has a significant effect on the growth of bacterivorous cillates (Taylor \& Berger, 1976; references cited in Curds \& Bazin, 1977; Alonso et a1,, 1981). Similar results have been noted with herbivorous cillates (Rubin \& Lee, 1976; Stoecker et al., 1981). Sherr et al. (1983) observed that the growth of a spectes of Monas fed four species of heterotrophic bacteria varied by a factor of 2.7 with different foods. The growth rate of Monas sp. 1 in this study was comparable for the two species of heterotrophic bacteria tested $(U=2.4$ and 2.0 day $^{-1}$ ). Good growth was also observed for Monas fed Synechococcus Strain WH $7803\left(U=1.7\right.$ day $\left.^{-1}\right)$. Johnson et al. (1982) have noted that a species of Synechococcus was sufficient to maintain the growth of the microflagellate Actinomonas for more than one year. Caron et al. (Appendix V) noted the presence of chroococcold cyanobacteria in the food vacuoles of heterotrophic microflagellates from the surface waters of Lake Ontario.

Unlike its growth on the heterotrophic bacteria and Synechococcus Strain WH 7803, the growth of Monas fed Synechococcus Strain WH 8101 was relatively slow $\left(U=0.39 \mathrm{day}^{-1}\right)$. The volume of this species was similar to the Synechococcus Strain WH 7803, so cell size cannot explain the poor growth of the mfcroflagellate on Strain WH 8101. However, Synechococcus Strain WH 8101 contains a different pigment composition than Strain WH 7803. Curds \& Bazin (1977) noted that several studies have shown that pigmentation of 
Figure 3.2. Growth curves of Monas sp. I fed two species of heterotrophic bacterla and two spectes of chroococcoid cyanobacteria.

(D) Serratia marinorubra

(O) Pseudomonas halodurans

( ) Synechococcus Strain WH 7803

(A) Synechococcus Strain WH 8101 


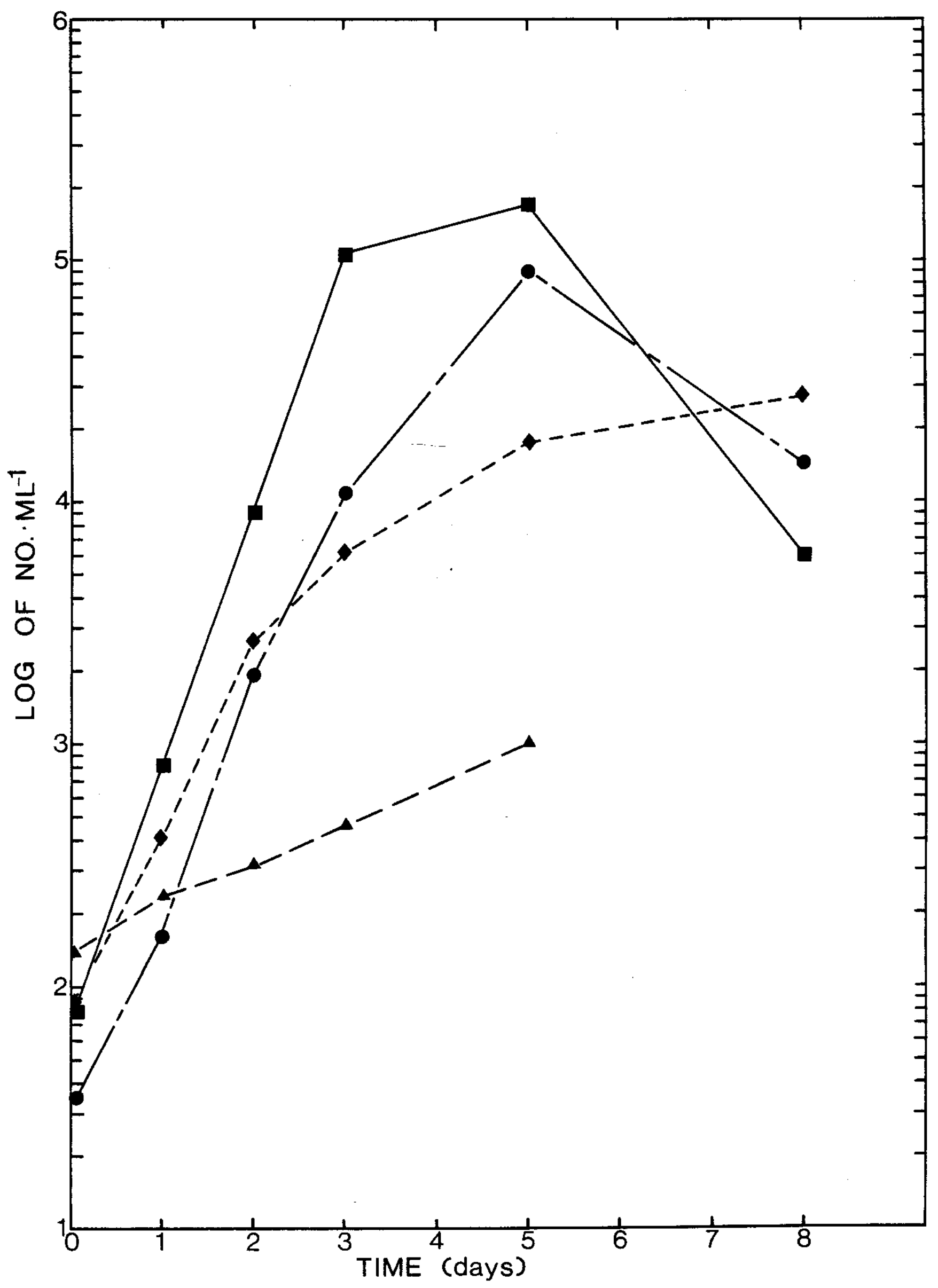


Table 3.1. Growth rates doubling times and cell yields of the microflagellate Monas sp. 1 grown on two specles of heterotrophic bacterla and two species of chroococcoid cyanobacteria.

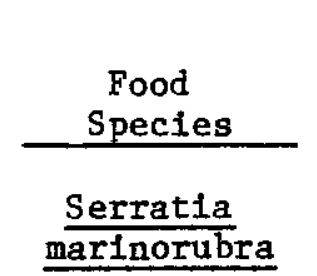

Pseudomonas halodurans

Synechococcus

Strain WH 7803

Synechococcus

Strain WH 8101

$\frac{\begin{array}{c}\text { Growth } \\ \text { Rate } \\ \left(\text { day }^{-1}\right)\end{array}}{2.42}$

1.96

1.74

0.39

42.7
Ce11

Yield

Time

(hr)

6.9

(\%)

\section{6}

8.5

68

9.6

7

31 
heterotrophic bacteria can affect the acceptability of bacteria as food for protozoa. Highly pigmented bacteria have been shown to be toxic to some ciliates. It is possible that some of the unacceptability of Strain 8101 and the acceptability of Strain WH 7803 may be explained by differences in their photosynthetic pigment composition.

The cell ylelds of Monas sp. 1 fed the four food types (Table 3.1) Indicate that heterotrophic bacteria were converted to microflagellate biomass more efficlently than were cyanobacterla. Cell yields for Monas fed heterotrophic bacterla are slightly higher than has been observed for other microflagellates (range $=20-49 \%$; Kopylov et al., 1980; Fenche1, 1982b; Sherr et al., 1983) but are within the range of values observed in studies with ciliates (range $=37-78 \%$; Curds \& Bazin, 1977). Sherr et al. (1983) noted that the yield of a species of Monas was temperature dependent. The highest yield in that study $(49 \%)$ was observed at $23.5^{\circ} \mathrm{C}$ (compared to $25^{\circ} \mathrm{C}$ in the present study). The culture temperature may therefore explain the high ylelds observed in the present study for Monas sp. 1 feeding on heterotrophic bacterla. Cell yield was not inversely correlated with the growth rate as was observed by Sherr et al. (1983).

Batch and Continuous Culture of Microflagellates:

The second batch culture experiment was carried out with Monas sp. 2 and Cryptobla maris fed $\underline{P}$. halodurans in order to determine the maximum specific growth $\left(U_{m}\right)$ and the cell yield at $U_{m}$ (Figure 3.3 and Table 3.2). This experiment was carried out with antibiotics present in the culture flasks to remain consistent with the continuous culture procedure. The use of $60 \mathrm{mg}$ $1^{-1}$ penicillin and $30 \mathrm{mg} 1^{-1}$ streptomycin to stop bacterlal growth did not affect the growth of the microflagellates. Maximum growth rates observed in batch cultures without antibiotics were virtually identical to growth rates in cultures with antibiotics. The growth rates of the two microflagellate 
Figure 3.3. Growth curves for Monas sp. 2 and Cryptobla maris fed Pseudomonas halodurans in batch culture. 


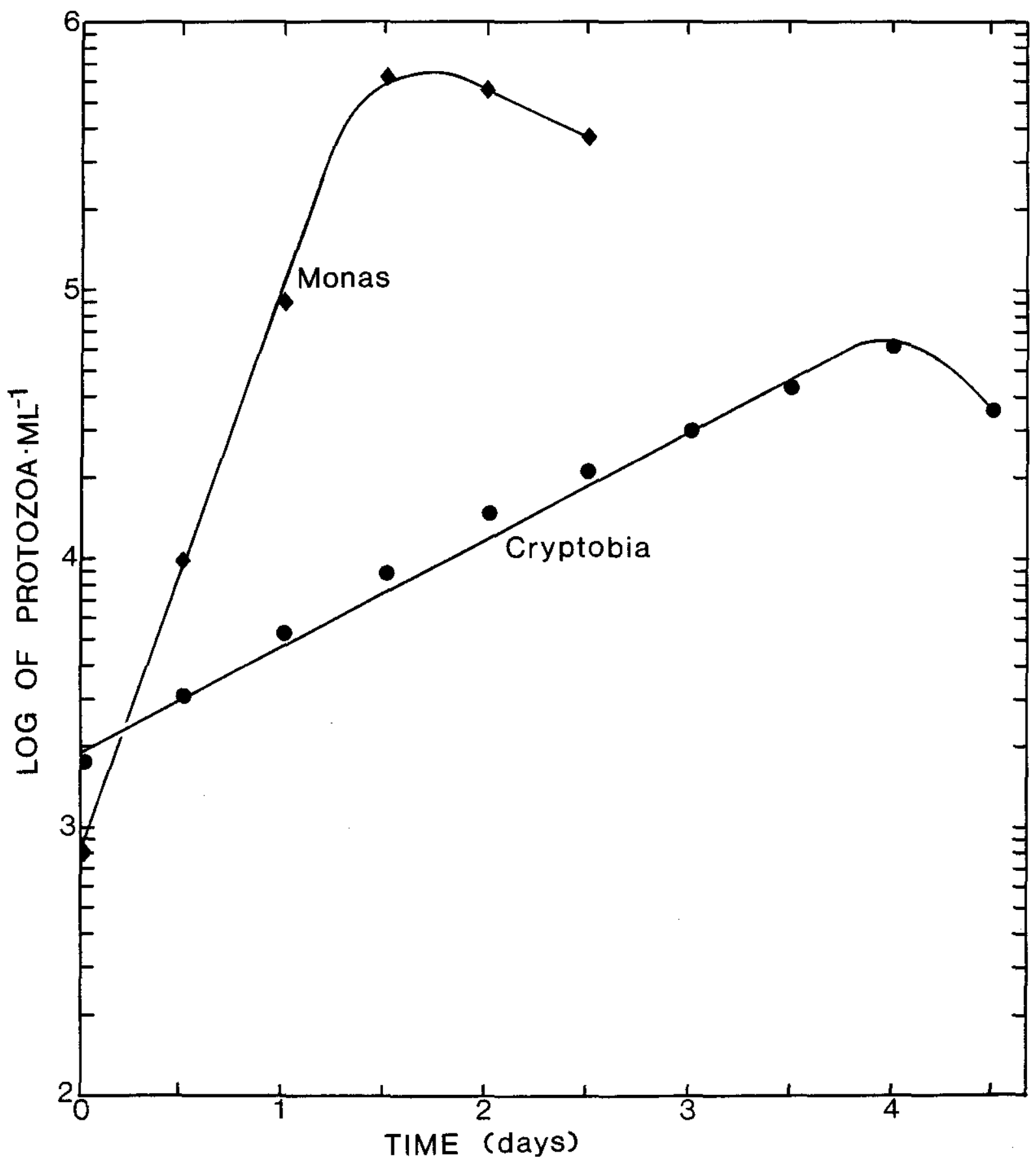


Table 3.2. Growth parameters of Monas sp. 2 and Cryptobia maris in batch culture.

\begin{tabular}{|c|c|c|c|c|c|}
\hline SPECIES & $\begin{array}{l}\text { GROWTH } \\
\text { RATE } \\
\left(\text { day }^{-1}\right)\end{array}$ & $\begin{array}{c}\text { DOUBLING } \\
\text { TIME } \\
\left(h r^{-1}\right) \\
\end{array}$ & $\begin{array}{c}\text { INITIAL } \\
\text { BACTERIAL } \\
\text { DENSITY } \\
\left(\text { no. mI }{ }^{-1} \text { ) }\right.\end{array}$ & $\begin{array}{l}\text { MAXIMUM } \\
\text { FLACELLATE } \\
\text { DENSITY } \\
\text { (no. } \text { ml-1 }^{-1} \text { ) }\end{array}$ & $\begin{array}{c}\text { CELL } \\
\text { YIELD } \\
(\%) \\
\end{array}$ \\
\hline$\frac{\text { Monas }}{\text { sp. } 2}$ & 4.40 & 3.78 & $5.82 \times 10^{7}$ & $6.02 \times 10^{5}$ & 48 \\
\hline$\frac{\text { Cryptobia }}{\text { maris }}$ & 1.00 & 16.6 & $5.82 \times 10^{7}$ & $6.04 \times 10^{5}$ & 61 \\
\hline
\end{tabular}


species employed in this experiment were quite different ( $U=1.0$ and 4.4 day ${ }^{-1}$ ), despite the fact that both species feed predominantly on bacterloplankton (confirmation for this mode of nutrition for Cryptobia is given in Chapter 4). Cell ylelds for both spectes in batch culture were high. These yields suggest that a considerable portion of the energy contained in bacterioplankton may be converted to microflagellate biomass in plankton communities.

The growth parameters of Monas sp. 2 and Cryptobia maris grown in continuous culture at three growth rates less than $U_{m}$ are shown in Table 3.3. Steady states were obtained with both species at growth rates as slow as $6 \%$ and $7 \%$ of $U_{m}$, respectively. These rates correspond to doubling times of $59 \mathrm{hr}$ and $238 \mathrm{hr}$. This indicates a remarkable plasticity in the growth rate of these microflagellates. Fenchel (1982b) has noted a similar ability for Ochromonas. Ochromonas was shown to be able to maintain a growth rate which was approximately $15 \%$ of $U_{m}\left(U=0.67\right.$ day $^{-1}$; doubling time $\left.=24 \mathrm{hr}\right)$.

The plasticity observed for the growth rates of microflagellates may be an adaptation which enables them to endure rapid temporal changes in food abundances in the plankton. Diel cycles in bacterial production have been suggested for natural bacterial populations (Sieburth et a1., 1977; Burney et a1., 1982). This pattern of bacterial growth would result in alternating perlods of high and low prey abundance for bacterial grazers. The ability of microflagellates to survive at a wide range of growth rates may allow them to keep pace with rapid bacterial growth when it takes place, and withstand near-starvation conditions in the absence of bacterlal growth.

Previous studies have noted that at least some bacterivorous ciliates will cease feeding if the bacterial concentration falls below a critical "threshold" concentration (Salt, 1967; Hamilton \& Preslan, 1970; Berk et a1., 1976; Fenche1, 1980a). This behavior is presumably a mechanism to conserve 
Table 3.3. Growth and feeding parameters of Monas sp. 2 and Cryptobia maris in continuous culture.

\begin{tabular}{|c|c|c|c|c|c|c|c|c|c|}
\hline $\begin{array}{l}\text { LUTION } \\
\text { RATE } \\
\text { ay }^{-1} \text { ) } \\
\end{array}$ & $\begin{array}{c}\text { PERCENT } \\
\text { OF } \\
\mu \mathrm{m} \\
\end{array}$ & $\begin{array}{c}\text { BACTERIA } \\
\text { AT STEADY } \\
\text { STATE } \\
\text { (no. } \mathrm{ml}^{-1} \text { ) } \\
\end{array}$ & $\begin{array}{l}\text { PROTOZOA } \\
\text { AT STEADY } \\
\text { STATE } \\
\text { (no. } \mathrm{m}^{-1} \text { ) } \\
\end{array}$ & $\begin{array}{c}\text { YIELD } \\
(\%) \\
\end{array}$ & $\left(\right.$ bac $\left.\mathrm{m1}^{\mathrm{m}_{\mathrm{s}}-1}\right)$ & $\begin{array}{c}\text { INGESTION } \\
\text { RATE } \\
\left.\text { (bac } \mathrm{flag}^{-1} \mathrm{hr}^{-1}\right) \text { (bac }\end{array}$ & $\begin{array}{l}\text { MAXIIAUM } \\
\text { INGESTION } \\
\text { RATE } \\
\left.\text { flag }^{-1} \mathrm{hr}^{-1}\right) \\
\end{array}$ & $\begin{array}{c}\text { FILTRATION } \\
\text { RATE } \\
\left(\mathrm{ml} \mathrm{flag}^{-1} \mathrm{hr}^{-1}\right) \\
\end{array}$ & $\begin{array}{c}\text { MAXIMUM } \\
\text { FILTRATION } \\
\text { RATE } \\
\left(\mathrm{m} 1 \mathrm{flag}^{-1} \mathrm{hr}^{-1}\right) \\
\end{array}$ \\
\hline .28 & 6 & $6.04 \times 10^{4}$ & $3.69 \times 10^{5}$ & 37 & $8.9 \times 10^{5}$ & 1.5 & 24 & $2.4 \times 10^{-5}$ & $2.7 \times 10^{-5}$ \\
\hline .73 & 17 & $2.19 \times 10^{5}$ & $5.40 \times 10^{5}$ & 53 & $1.1 \times 10^{6}$ & 2.7 & 16 & $1.2 \times 10^{-5}$ & $1.5 \times 10^{-5}$ \\
\hline .39 & 32 & $5.29 \times 10^{5}$ & $5.13 \times 10^{5}$ & 52 & $\frac{1.1 \times 10^{6}}{\overline{\mathrm{X}}=1.0 \times 10^{6}}$ & 5.1 & $\frac{15}{\bar{x}=18}$ & $1.0 \times 10^{-5}$ & $\frac{1.4 \times 10^{-5}}{\bar{X}=1.9 \times 10^{-5}}$ \\
\hline .07 & 7 & $3.27 \times 10^{5}$ & $6.93 \times 10^{4}$ & 9 & 4. $3 \times 10^{6}$ & 1.8 & 25 & $1.0 \times 10^{-5}$ & 1. $0 \times 10^{-5}$ \\
\hline .28 & 28 & $2.06 \times 10^{6}$ & $4.94 \times 10^{5}$ & 65 & $5.3 \times 10^{6}$ & 1.0 & 3.6 & $4.8 \times 10^{-7}$ & $6.8 \times 10^{-7}$ \\
\hline .37 & 37 & $2.70 \times 10^{6}$ & $4.04 \times 10^{5}$ & 56 & $\frac{4.6 \times 10^{6}}{\bar{X}=4.7 \times 10^{6}}$ & 1.6 & $\frac{4.3}{\bar{x}=4.0^{\star}}$ & $5.9 \times 10^{-7}$ & $\frac{9.3 \times 10^{-7}}{\overline{\mathrm{X}}=8.1 \times 10^{-7}}$ \\
\hline
\end{tabular}

hese averages were based only on the data from trial at $\mu=0.28$ day $^{-1}$ and $\mu=0.37$ day ${ }^{-1}$. Results from the trial at $=0.07$ day $^{-1}$ were omitted because of the possibility of bias due to wall growth (see text). 
energy in oligotrophic environments, and has been proposed as one explanation for the near absence of bacterivorous clliates from the open ocean plankton (Fenche1, 1980b). Feeding thresholds were not observed for the microflagellates in this study. Steady states (i.e. constant and sustained growth) were observed at all dilution rates tested, and the bacterial densities established at these dilution rates were generally as low as bacterlal densities observed in-situ. The lowest bacterial densities were $6.04 \times 10^{4}$ bacteria ml $\mathrm{ml}^{-1}$ for Monas and $3.27 \times 10^{5}$ bacteria ml ${ }^{-1}$ for Cryptobia. The latter density is characteristic of bacterlal densities observed in epipelagic open ocean communtties while the former value is characteristic of the aphotic open ocean (Chapter 1). If feeding thresholds exist for these microflagellates, they are at levels less than the densities of bacterla normally observed in plankton communitles. These results suggest that microflagellates are capable of reducing bacterial density to levels observed in-situ, and are capable of maintaining their growth at those low food abundances.

The density of bacteria in the continuous culture vesse1s was dependent on the growth rate of the microflagellates in the vessel (Table 3.3). Bacterlal density at steady state decreased as the growth rate of the microflagellates (1.e. dilution rate) decreased. These results suggest relatively low growth rates of microflagellates in open ocean plankton communities and faster rates inshore. However, it is not possible to extrapolate these results directly to plankton communitles because of differences in the average size of cultured bacteria and natural populations. Natural bacterial assemblages are characterized by cells of considerably smaller volumes than that of $\underline{P}$. halodurans (Watson et al., 1977). In addition, food type also affects the growth rate of microflagellates (Figure 3.2 and Table 3.1 ) and the effects of a mixed diet on the growth of microflagellates are unknown. 
Half-saturation constants $\left(K_{s}\right)$ were calculated from equation 2 for each dilution rate tested for both microflagellates (Table 3.3). This calculation assumes that the Monod equation adequately describes the growth of the microflagellates (Fenchel, 1982b). The three values of $\mathrm{K}_{\mathrm{s}}$ for each microflagellate at different dilution rates agree reasonably well ( $\overline{\mathrm{X}}=$ $1.0 \times 10^{6}$ bacterla ml $^{-1}$ for Monas and $\overline{\mathrm{x}}=4.7 \times 10^{6}$ bacteria ml ${ }^{-1}$ for Cryptobia). This agreement indicates that growth of the microflagellates is adequately described by the Monod equation. The $\mathrm{K}_{\mathrm{s}}$ for Monas sp. 2 Indicates a potentlal for relatively rapidly growth at in-situ densities of bacterla. A growth rate of 2.2 day $^{-1}$ could be maintalned by a bacterial population equivalent to $1.0 \times 10^{6} \mathrm{P}$. halodurans $\mathrm{ml}^{-1}$. This value is comparable to the lowest $\mathrm{K}_{\mathbf{s}}$ calculated for several microflagellate specles by Fenchel (1982b). The growth potential of Cryptobia at low bacterial density was less than that for Monas. A bacterial density equivalent to $4.7 \times 10^{6} \underline{P}$. halodurans $\mathrm{ml}^{-1}$ would support a growth rate of only 0.5 day $^{-1}$. Cel1 ylelds of Monas and Cryptobia grown in continuous culture at growth rates greater than $10 \%$ of $U_{m}$ were similar to cell yields observed for the microflagellates growing at $U_{m}$ in batch culture. These results confirm the observations of Fenchel (1982b) and Sherr et al. (1983) that "maintenance energy" requirements for microflagellates are a relatively small fraction of the total energy budget. Low cell yields were observed when microflagellate growth rates were less than $10 \%$ of $U_{m}$ due to the low densities of microflagellates at steady state during these trials. It can be seen from equation 5 that the steady state density of microflagellates is dependent only on $S_{r}$ and $\bar{s}$ since $Y$ is relatively unchanging. However, the density of Cryptobla in the culture vessel at $\mathrm{U}=0.07 \mathrm{day}^{-1}\left(7 \%\right.$ of $\mathrm{U}_{\mathrm{m}}$ ) was nearly an order of magnitude lower than its density at higher growth rates and the density of Monas at $U=0.28$ day $^{-1}\left(6 \%\right.$ of $\left.U_{m}\right)$ was only $73 \%$ of its density 
at higher growth rates. Microflagellates were attached to the walls of the culture vessel in all experimental trials, but attachment was greater at the lowest dilution rates tested. Wall growth was insignificant in the trials where the dilution rate was greater than $10 \%$ of $\mathrm{U}_{\mathrm{m}^{*}}$. It is suspected that an enhancement of microflagellate attachment at a $U$ less than $10 \%$ of $U_{m}$ coupled with the very slow input of food may explain the low cell ylelds observed in these trials. Nonetheless, half-saturation constants calculated for both microflagellates grown at a growth rate less than $10 \%$ of $U_{m}$ were in agreement with $\mathrm{K}_{\mathrm{s}}$ values observed at higher growth rates. Average cell volumes of the microflagellates grown in continuous culture were not significantly different for the three growth rates tested, but were less than the volumes of the microflagellates grown in batch culture at $U_{m}$ (average volumes of Monas and Cryptobla in continuous were approximately $70 \%$ of their volumes in batch culture at $\mathrm{U}_{\mathrm{m}}$ ). The cell volume of $\underline{\mathrm{P}}$. halodurans also decreased somewhat as the experiment proceeded. Cell yields at steady state were based on volumes of protozoa and bacteria at individuals steady states. One advantage of continuous culture is that ingestion rates (bacteria consumed flagellate ${ }^{-1} \mathrm{hr}^{-1}$ ) can be measured directly at steady state from equation 6 . Ingestion rates measured in this way were determined at each dilution rate (Table 3.3). They indicate that microflagellates can sustain their growth at ingestion rates as 10 as 1 bacterlum flagellate ${ }^{-1} \mathrm{hr}^{-1}$. In contrast, other studies have shown that microflagellates can consume several hundred bacterla flagellate ${ }^{-1} \mathrm{hr}^{-1}$ (Kopylov et al., 1980; Davis, 1982; Fenchel, 1982b). Ingestion rates calculated at $U=0.28$ day $^{-1}$ for

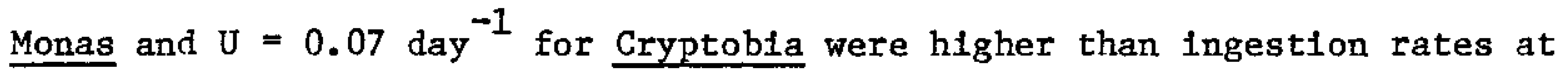
slightly higher growth rates. This result is presumably an artifact caused by the lower microflagellate densities observed in these trials (due to attachment of microflagellates at the lowest growth rates). 
The maximum ingestion rate of the microflagellates can be calculated from the measurable parameters at steady state using the equation

$$
I=I_{m} \frac{s}{s+K_{s}}
$$

Values calculated in this manner are generally lower than maximum ingestion rates obtained in other studies which have employed batch culture. For example the value $I_{\mathrm{m}}=18$ bacteria flagellate ${ }^{-1} \mathrm{hr}^{-1}$ calculated for Monas sp. 2 in this study was an order of magnitude less than values obtalned by Fenche1 (1982d) and Davis (1982) for species of Paraphysomonas. The maximum Ingestion rate for Cryptobia $\left(I_{m}=4\right.$ bacteria flagellate ${ }^{-1} \mathrm{hr}^{-1}$ ) was lower than any other values in those studies ( $I_{\mathrm{m}}$ calculated for Cryptobia at $U=0.07 \mathrm{day}^{-1}$ was not considered because of the possible artifact Incurred by wall growth (see above). The lower ingestion rates observed in this study are due in part to the different size and growth characteristics of the microflagellates employed. Sherr et al. (1983) measured a range of Ingestion rates of 10 to 75 bacteria flagellate $\mathrm{hr}^{-1}$ for a species of Monas which was similar in size to Monas sp. 2. The minimum doubling times and the corresponding cell ylelds of Monas sp. 2 and Cryptobla maris in batch culture $(3.8 \mathrm{hr}$ and $48 \%$, and $16.6 \mathrm{hr}$ and $61 \%$, respectively) suggest that ingestion rates of bacteria by microflagellates growing at $U_{m}$ should be on the order of 25 and 5.8 bacterfa flagellate ${ }^{-1}$ $\mathrm{hr}^{-1}$ for Monas and Cryptobla, respectively. This rough approximation of $I_{m}$ was determined using the equation

$$
I_{\text {batch }}=\frac{\left(V_{\text {pro }}\right)}{(\mathrm{Y})(\mathrm{DT})\left(\mathrm{V}_{\mathrm{bac}}\right)}
$$

where $V_{\text {pro }}$ and $V_{b a c}$ are the average cell volumes of the microflagellates and bacterla, respectively, and DT is the microflagellate doubling time. Therefore, $I_{m}$ estimated from the batch culture experiment agrees reasonably well with the $I_{m}$ calculated from the continuous culture data. 
Clearance rates ( $\mathrm{F}$, measured in $\mathrm{ml}$ flagellate $\mathrm{hr}^{-1}$ ) and maximum clearance rate $\left(F_{\mathrm{m}}\right)$ were also calculated for each of the continuous culture trials based on equation 7 for $F$ and on the equation of Fenchel (1982b) for $F_{m}$ (Table 3.3). Observed clearance rates for the two microflagellates were near the calculated $F_{m}$ at the slowest growth rates tested due to low bacterial density in these trials. Clearance rates decreased with increasing bacterial density at steady state, an observation which has been previously noted (Davis, 1982).

Competition Experiment:

The results of the batch culture and continuous culture experiments Indicate that Monas sp. 2 has a greater $U_{m}$ and lower $K_{s}$ than Cryptobia marts. These characteristics suggest that Monas has a competitive advantage for existing on a diet of $\underline{P}$. halodurans based on both growth rate and substrate affinity, and should always outcompete Cryptobla when the abundance of $\underline{\text {. halodurans }}$ is the sole factor limiting growth of both species (see Harder et al., 1977; Figure 4a). The results of the competition experiment support this hypothesis (Figure 3.4 ). The continuous culture vessel containing Cryptobia at steady state $\left(U=0.28\right.$ day $^{-1}$ ) was inoculated with a small amount of the Monas culture. Monas grew rapidly and reached a maximum density that was similar to 1 ts density in the continuous culture vessel with Monas alone growing at 0.28 day $^{-1}$. Its growth coincided with a decrease in the density of bacteria from the steady state value when only Cryptobia was present $\left(5 \times 10^{5} \mathrm{ml}^{-1}\right)$ to a density of $6 \times 10^{4} \mathrm{ml}^{-1}$. This density was equivalent to bacterial density observed in the continuous culture vessel with only Monas growing at $0.28 \mathrm{day}^{-1}$ at steady state. The density of Cryptobia decreased exponentially following inoculation of the culture with Monas. Linear regression of this decrease showed a correlation coefficient of 0.99 and a slope of $-0.45 \mathrm{day}^{-1}$ instead of -0.28 day $^{-1}$ (the dilution rate). 
Figure 3.4. Competition experiment between Monas sp.2 and Cryptobia maris performed in continuous culture at a dilution rate of $0.28 \mathrm{day}^{-1}$. A culture vessel containing Cryptobia at steady state was inoculated with Monas at time zero.

\author{
(A) Cryptobia maris \\ ( ) Monas sp. 2 \\ (ㅁ) bacterial food (Pseudomonas halodurans)
}




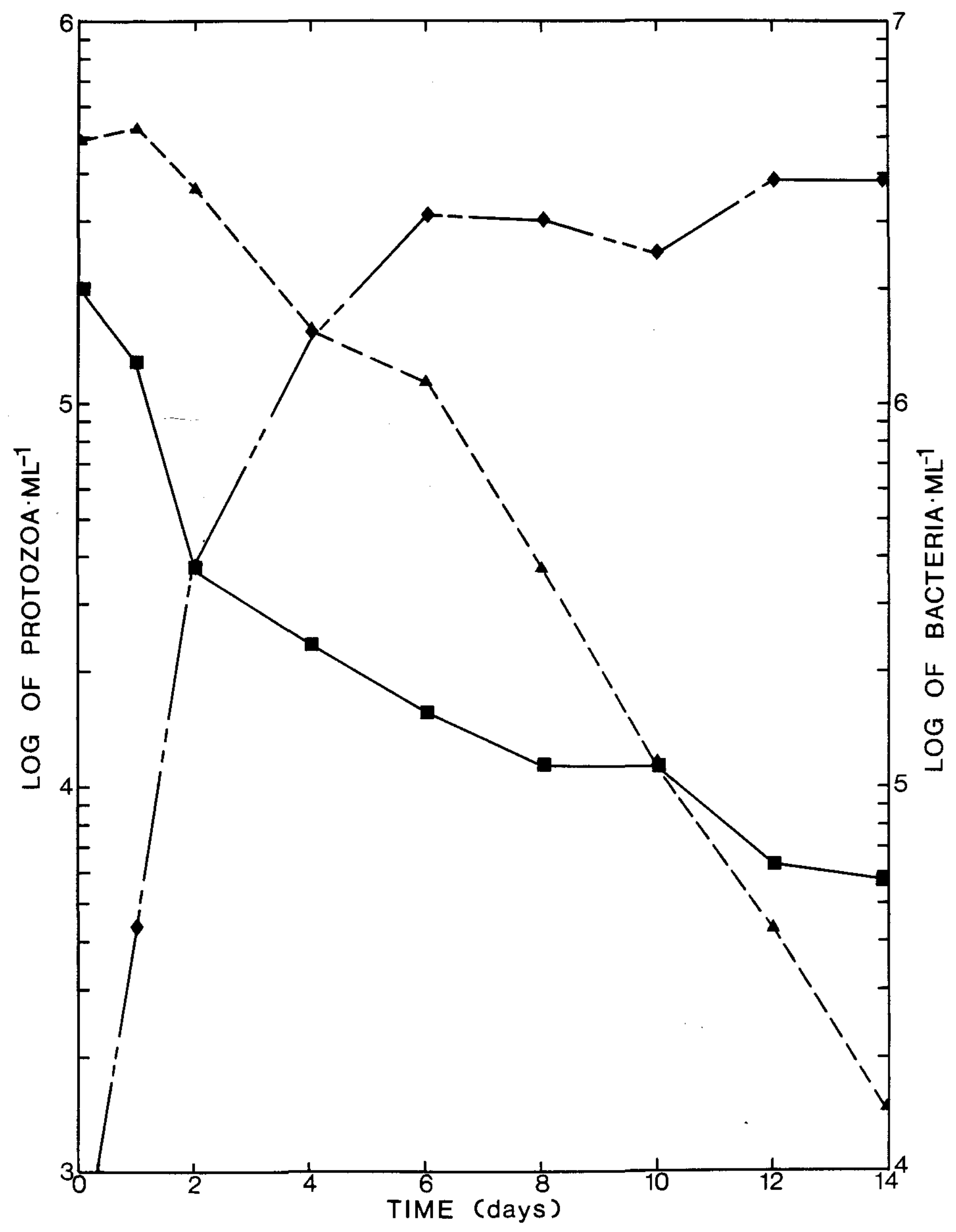


Cryptobia disappeared from the vesse1 at a rate which was 0.21 day $^{-1}$ in excess of the dilution rate. This disappearance was presumably due to starvation of Cryptobia in the culture vessel. The reduction in the bacterial density due to the grazing activities of Monas may have resulted in poor food capture by Cryptobia, resulting in a rate of disappearance which exceeded the dilution rate.

The faster growth rate and lower $\mathrm{K}_{\mathrm{s}}$ of Monas relative to Cryptobia should allow it to outcompete Cryptobia when unlimited food is present (1.e. when growth rates are maximal) and also when food is scarce (due to its lower $\mathrm{K}_{\mathrm{s}}$ ). This competitive superiority was shown in the competition experiment between the two microflagellates (Figure 3.4) run at a relatively slow growth rate. From these results it is difficult to envision how Cryptobia can malntain Itself in the plankton if Monas and Cryptobla compete for the same food source. One possible explanation is that Cryptobia is capable of withstanding starvation conditions better than Monas. A Most Probable Number culture procedure was performed on these two specles during exponential growth, early stationary growth and late stationary growth (Appendix II; Table AII.2). The density of viable Cryptobia decreased more slowly than the density of Monas, indicating a superiority of Cryptobia to Monas in its ability to withstand starvation conditions. Therefore, a selective advantage for Cryptobla may exist where perlodic hiatuses in the food supply occur. Alternatively, other factors may explain the planktonic existence of Cryptobia. Other bacterial species may alter the growth rate and $\mathrm{K}_{\mathrm{S}}$ relationships between Monas and Cryptobia, or feeding selectively by the microflagellates in nature may reduce or eliminate competition between them. The 1mportance of these factors awalts further study. Finally, the competition experiment was artificlal in the sense that the bacterial population was unchanging (non-growing). It has been demonstrated 
mathematically that coexistence of two protozoan populations competing for the same bacterial population can occur if the bacterla are growing. Coupled with the complicating factors of prey selectivity and starvation resistance, the coexistence of Monas and Cryptobia seems possible. Impact of Microflagellate Grazing:

Several studies have attempted to estimate the impact of grazing by heterotrophic microflagellates on bacterioplankton populations by extrapolating the results of laboratory experiments. These studies are summarized in Table 3.4. Ingestion rates (bacteria consumed flagellate ${ }^{-1}$ $\mathrm{hr}^{-1}$ ) determined in batch cultures were multiplied by the observed density of heterotrophic microflagellates (usually assumed to be equivalent to the density of heterotrophic nanoplankton; see Chapter 1) and then divided by the density of bacteria in the same environment to yield an estimate of the amount of water filtered by the microflagellate population each day. Based on this rate of removal of bacterioplankton, a minimum doubling time of the bacterloplankton population was calculated (1.e. the amount of growth which is required to ensure that the bacterial density remains constant). Clearance rates of microflagellates and minimum bacterial doubling times were also calculated based on the results of this study. Ranges of $5 \times 10^{5}$ to $2 \times 10^{6}$ bacteria $\mathrm{ml}^{-1}$ and $5 \times 10^{2}$ to $2 \times 10^{3}$ microflagellates $\mathrm{ml}^{-1}$ were chosen to represent an environmental gradient from neritic to open ocean conditions (Chapter 1). A range of ingestion rates were then calculated for a population of microflagellates having growth characteristics similar to Monas sp. 2 or Cryptobia maris (Table 3.3 ). These rates were then used to calculate a range of clearance rates and the resulting minimum doubling times for the bacterial population. Values calculated in this way (Table 3.4) indicate that a population of microflagellates with feeding characteristics similar to Cryptobla would have a very small effect on bacterial growth $(1-3 \%$ of the 
Table 3.4. Ranges of the estimated clearance rates of microflagellate populations in-situ and the resulting minimum doubling times of bacterioplankton calculated from varłous studies.

\begin{tabular}{ccc} 
Reference & $\begin{array}{c}\text { Clearance } \\
\text { (\% of the water day-1) }\end{array}$ & $\begin{array}{c}\text { Bacterial } \\
\text { Doubling Time } \\
\text { (hr) }\end{array}$ \\
\cline { 2 - 3 } $\begin{array}{c}\text { Fenche1 (1982d) } \\
\text { Linley et al. (1983) }\end{array}$ & $120-720$ & $2.3-13.9$ \\
$\begin{array}{l}\text { Present study } \\
\text { (based on the growth } \\
\text { of Monas) }\end{array}$ & $10-70$ & $30-200$ \\
$\begin{array}{l}\text { Present study } \\
\text { (based on the growth } \\
\text { of Cryptobia) }\end{array}$ & $1.0-3.4$ & $57-119$ \\
\hline
\end{tabular}


water cleared day ${ }^{-1}$ ). However, if the population has growth characteristics similar to Monas, $14-29 \%$ of the water would be filtered daily. This corresponds to doubling times of 57 to $119 \mathrm{hr}$ for the bacterial population.

The clearance rates and bacterial doubling times calculated using the growth parameters of Monas sp. 2 fall within the range of values determined by Fenchel (1982d), but are considerably lower than values calculated by Linley et al. (1983) and Davis (1982). However, Linley et al. (1983) employed the maximum ingestion rates observed by Fenchel (1982d) to determine grazing rates. In-situ bacterlal density presumably would not support these maximal rates and consequently they may have overestimated the bacterial growth rate. Davis (1982) calculated ingestion rates of microflagellates feeding on actively growing bacterial populations in batch culture. It is possible that methodological differences between that study and the present one may account for his high clearance rates $\left(120-720 \%\right.$ day $\left.^{-1}\right)$. Alternatively, the food organism chosen in that study (a Vibrio species) may support faster ingestion rates than the bacterla used as food in this and other studies. The ingestion rates estimated by Davis (1982) for a variety of bacterial densities ranging from estuarine to open ocean conditions (50-210 bacteria consumed flagellate $\mathrm{hr}^{-1}$ ) exceed $I_{m}$ calculated for both species in this study. Continuous culture provides an alternative to batch culture for the examination of growth parameters of bacterivorous heterotrophic microflagellates at growth rates less than $U_{m} \cdot$ Attainment of steady state conditions using a static bacterlal population allows the determination of the half-saturation constant, cell yield, and ingestion rate. In addition, the ability of microflagellates for sustained growth at growth rates less than $U_{m}$ can be examined. However, batch culture still provides the only way of determining the maximum specific growth and the cell yield at $U_{m}$. The combined use of these culture techniques can provide valuable information 
concerning the growth characteristics of bacterivorous protozoa, and may be the most appropriate manner to evaluate the feeding behavior and growth parameters of these microorganisms. 


\section{REFERENCES}

Alonso, P., I. Gil \& D. Rodriguez. 1981. Nutritional effeciency of different bacterial species on the growth of Tetrahymena pyriformis $W$. Protistologica 17: 199-201.

Azam, F., T. Fenche1, J.G. Field, J.S. Gray, L.A. Meyer-Reil \& F. Thingstad. 1983. The ecological role of water-column microbes in the sea. Mar. Ecol. Prog. Ser. 10: 257-263.

Berk, S.G. R.R. Colwell \& E.B. Small. 1976. A study of feeding responses to bacterial prey by estuarine clliates. Trans. Amer. Micros. Soc. 95: $514-520$.

Burney, C.M., P.G. Davis, K.M. Johnson \& J.McN. Sleburth. 1982. Die1 relationships of microbial trophic groups and in-situ dissolved carbohydrate dynamics in the Cartbbean Sea. Mar. Biol. 67: 311-322. Caron, D.A. 1983. Technique for enumeration of heterotrophic and phototrophic nanoplankton using epifluorescence microscopy, and comparison with other procedures. App1. Environ. Microb1o1. 46: 491-498. Caron, D.A., P.G. Dav1s, L.P. Madin \& J.McN. Sieburth. 1982. Heterotrophic bacteria and bacterfvorous protozoa in oceanic macroaggregates. Science 218: $795-797$.

Curds, C.R. 1971. A computer-simulation study of predator-prey relationships in a single-stage continuous-culture system, Water Res, 5: 793-812.

Curds, C.R. \& M.J. Bazin. 1977. Protozoan predation in batch and continuous culture. Adv. Aquatic Microbiol. 1: 115-176.

Davis, P.G. 1982. Bacterivorous flagellates in marine waters. Ph.D. Thesis, University of Rhode Island, $218 \mathrm{pp}$.

Davis, P.G., D.A. Caron \& P.W. Johnson \& J.McN. Sieburth. Submitted. Geographic, seasonal and diel distribution of phototrophic and heterotrophic components of the picoplankton and nanoplankton in the North 
Atlantic. Mar. Eco1. Prog. Ser.

Davis, P.G. \& J.McN. Sieburth. 1982. Differentlation of the photosynthetic and heterotrophic populations of nanoplankters by epifluorescence microscopy. Ann. Inst. oceangr., Par1s 58(S): 249-259.

Fenche1, T. 1967. The ecology of marine microbenthos. I. The quantitative importance of clliates as compared with metazoans in various types of sediments. Ophel1a 4: 121-137.

Fenche1, T. 1980a. Suspension feeding in clliated protozoa: Functional response and particle size selection. Microb. Ecol. 6: 1-11.

Fenchel, T. 1980b. suspension feeding in ciliated protozoa: Feeding rates and their ecological significance. Microb. Ecol. 6: 13-25.

Fenche1, T. 1982b. Ecology of heterotrophic microflagellates. II. Bloenergetics and growth. Mar. Ecol. Prog. Ser. 8: 225-231.

Fenchel, T. 1982d. Ecology of heterotrophic microflagellates. IV. Quantitative occurrence and Importance as bacterial consumers. Mar. Ecol. Prog. Ser. 9: 35-42.

Ferguson, R.L. \& P. Rublee, 1976. Contribution of bacteria to standing crop of coastal plankton. Limnol. Oceanogr. 21: 141-145.

Hamilton, R.D. \& J.E. Preslan. 1970. Observations on the continuous culture of a planktonic phagotrophic protozoan. J. exp. mar. Biol. Ecol. 5: 94-104.

Harder, W., J.G. Kuenen \& A. Matin. 1977. Microbial selection in continuous culture. J. Appl. Bacteriol. 43: 1-24.

Herbert, D., R. Elsworth \& R.C. Telling. 1956. The continuous culture of bacteria; a theoretical and experimental study. J. Gen. Microbiol. 14: $601-622$.

Hibberd, D.J. 1979. Notes on the ultrastructure of the genus Paraphysomonas (Chrysophyceae) with special reference to $\underline{P}$. bandaiensis Takahashi. Arch. 
Protistenk. 121: 146-154.

Johnson, P.W., H. Xu \& J.McN. Sieburth. 1982. The utilization of

chroococcoid cyanobacterla by marine protozooplankters but not by calanoid copepods. Ann. Inst. oceanogr., Paris 58(S): 297-308.

Kopylov, A.I., T.I. Mamayeva \& S.F. Batsanin. 1980. Energy balance of the colorless flagellate Parabodo attenuatus (Zoomastigophora, Protozoa). Oceanol. 20: 705-708.

Legner, M. 1980. Growth rate of infusorian populations. Adv. Aquatic Microbiol. 2: 205-255.

Linley, E.A.S., R.C. Newell \& M.I. Lucas. 1983. Quant1tative relationships between phytoplankton, bacteria and heterotrophic microflagellates in shelf waters. Mar. Ecol. Prog. Ser. 12: 77-89.

Monod, J. 1949. The growth of bacterlal cultures. Ann. Rev. Microbiol. 3: $371-394$.

Ramsay, A.J. 1978. Direct counts of bacteria by a modified acridine orange method in relation to their heterotrophic activity. N. Z. J. Mar. Freshwater Res. 12: 265-269.

Rubin, H.A. \& J.J. Lee. 1976. Informational energy flow as an aspect of the ecological efficlency of marine cillates. J. Theor. Biol. 62: 69-91. Salt, G.W. 1967. Predation in an experimental protozoan population (Woodruffia-Parameclum). Ecol. Monographs. 37: 113-144.

Sherr, B.F. \& E.B. Sherr. \& T. Berman. 1983. Growth, grazing and ammonfa excretion rates of a heterotrophic microflagellate fed four species of bacteria. Appl. Environ. Microbio1. 45: 1196-1201.

Sherr, B.F., E.B. Sherr \& S.Y. Newell. 1984. Abundance and productivity of heterotrophic nanoplankton in Georgia coastal waters. J. Plankton Res. 6: 195-202.

Sleburth, J.McN., K.M. Johnson, C.M. Burney \& D.M. Lavole. 1977. Estimation 
of In-situ rates of heterotrophy using diurnal changes in dissolved organic matter and growth rates of picoplankton in diffusion culture. Helgolander wiss. Meeresunters. 30: 565-574.

S1lver, M.W., M.M. Gowing, D.C. Brownlee \& J.0. Corliss. 1982. Protozoan colonists of sinking detritus. EOS, Trans. Amer. Geophys. Union 63: 959 (Abstr.).

Silver, M.W., M.M. Gowing, D.C. Brownlee \& J.0. Corliss. 1984. Ciliated protozoa assoclated with oceanic sinking detritus. Nature 309: 246-248.

Stevenson, L.H. 1978. A case for bacterial dormancy in aquatic systems. Microb. Ecol. 4: 127-133.

Stoecker, D., R.R.L. Guillard, \& R.M. Kavee. 1981. Selective predation by Favella ehrenberg11 (Tintinnia) on and among dinoflagellates. Biol. Bull. 160: $136-145$.

Taylor, W.D. 1978. Growth responses of clliate protozoa to the abundance of their bacterlal prey. Microb. Ecol. 4: 207-214.

Taylor, W.D. \& J. Berger. 1976. Growth responses of cohabiting cillate protozoa to various prey bacteria. Can. J. Zool. 54: 1111-1114.

Watson, S.W., T.J. Novitsky, H.L. Quinby \& F.W. Valois. 1977. Determination of bacterial number and biomass in the marine environment. Appl. Environ. Microbiol. 33: 940-946. 
$-139-$

CHAPTER 4

GRAZING OF ATTACHED BACTERIA

BY HETEROTROPHIC MICROFLAGELLATES 


\section{ABSTRACT}

Several investigations have noted that heterotrophic microflagellates are often associated with particulate material in the plankton. These studies, and observations of the feeding activities of microflagellates in culture suggested that these bacterivorous protozoa may be capable of grazing bacteria attached to particles. Four species of microflagellates were examined for their ability to graze attached and unattached bacteria. The species tested displayed pronounced differences in their ability to graze Pseudomonas halodurans attached to chitin particles. Two specles (Monas sp. and Cryptobia maris) were capable of grazing unattached bacterla, but showed no ability to graze attached or aggregated cells. In contrast, Rhynchomonas nasuta and Bodo nanorensis showed marked preferences for attached and aggregated bacteria but a very limited ability to graze unattached cells. The density of attached bacteria was reduced by an order of magnitude due to grazing by these species of microflagellates. These results imply that the pelagic existence of microflagellates which graze attached bacteria may be strongly linked to the distribution of suspended particles and their associated bacteria. Furthermore, removal of attached bacteria by microflagellates may significantly affect the density of bacteria attached to particles in the plankton. Thus, the results also have implications for the controversy concerning the 1mportance of attached and free-living bacteria in the plankton. 


\section{INTRODUCTION}

This study was designed to attempt to determine the importance of particles for the pelagic existence of microflagellates. Previous work (Chapter 2; Caron et al., 1982; Fenche1, 1982d; Davo11, 1983; Pomeroy, 1983) has documented the existence of large numbers of heterotrophic microflagellates on microscopic and macroscopic detrital particles (Figure 4.1). Microflagellate densities on these particles have been shown to exceed their densities in the surrounding water by more than four orders of magnitude (Chapter 2; Caron et a1., 1982). These observations suggested that microflagellates might be using bacteria attached to particles as a food source. These microorganisms have a well-documented ability to graze unattached bacterla (Chapter 3; Haas \& Webb, 1979; Dav1s, 1982; Davis \& Sleburth, 1982; Fenche1, 1982b) but their ability to graze bacteria attached to particles has not been adequately addressed.

It is possible that microflagellates associated with surfaces simply use these particles as an attachment site and actually graze unattached cells. Fenchel (1982a) has suggested that some species attach in order to make more efficient use of flagellar movements used to create feeding currents. While this behavior cannot be ruled out as an explanation for the affinity of microflagellates for surfaces, microscopical observations have suggested to me that grazing on attached bacterla may be a partial explanation for their high abundance on particles. Several species of microflagellates which I have successfully cultured are poor swimmers but are quite mobile on solid surfaces where they appear to actively search these surfaces with a side-to-side sweeping motion of their flagella. This behavior has suggested that these surface-associated species of microflagellates might be adapted for exploiting bacterial populations attached to surfaces. This ability might explain in part the highly elevated densities of these protozoa in macroscopic detrital 
Figure 4.1. EpIfluorescence photomicrographs of primulin-stained heterotrophic microflagellates associated with microaggregates in a seawater sample from the Sargasso Sea. Arrows show the location of microflagellates. 
$-142 a-$
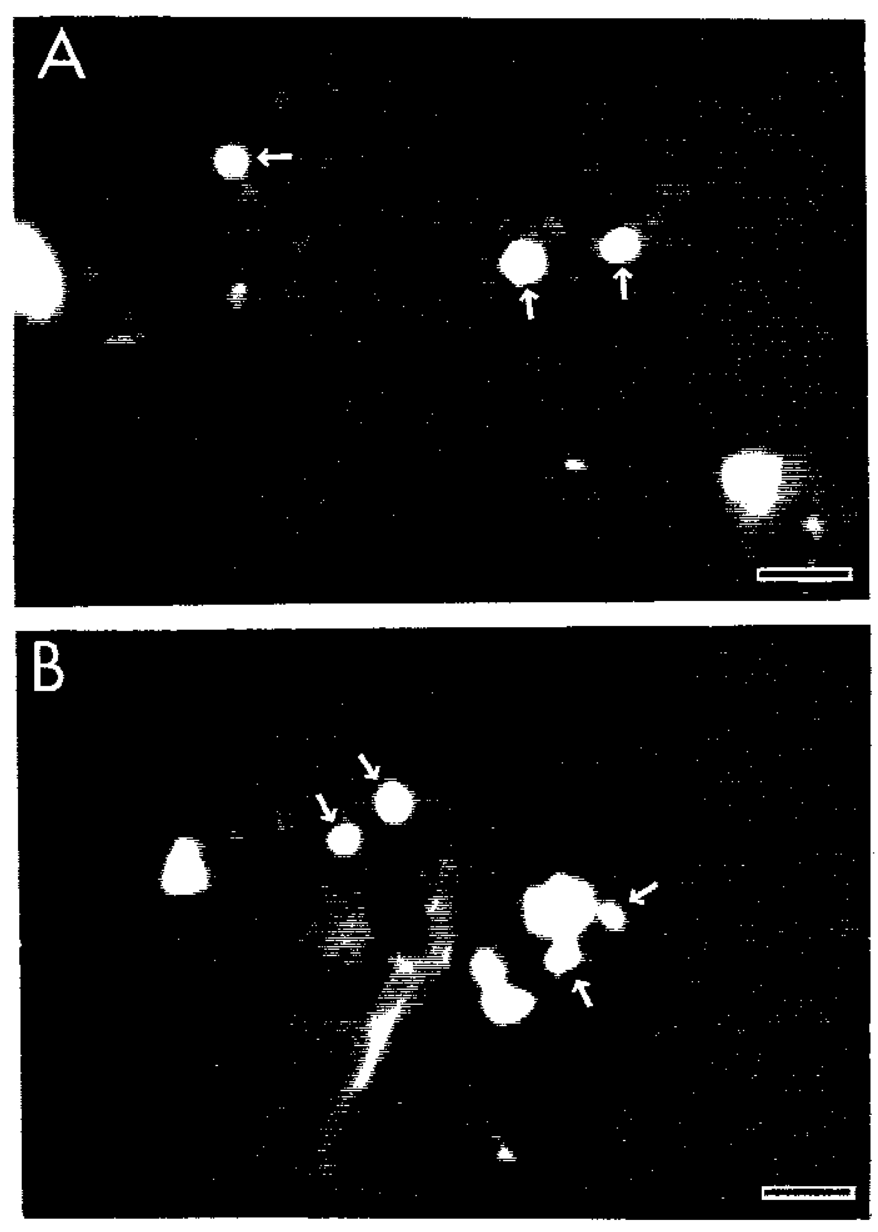
aggregates (Chapter 2; Caron et a1., 1982).

Another consideration for this behavior of microflagellates involves the implications which grazing of attached bacteria has for research dealing with bacterial attachment in aquatic environments. Controversy has existed for over 40 years concerning the importance of attachment for bacteria in aquatic environments. Work by Zobell (1943) and others demonstrated that surfaces enhanced the growth of bacteria in an aqueous environment. Since then, Investigators have attempted to experimentally demonstrate and theoretically explain this phenomenon. It has been suggested that in a dilute aqueous environment surfaces create microzones which are conducive to bacterial growth due to the adsorption of organic material. The more dilute the environment, the more important these microenvironments would become and the greater the benefit of attachment (Wangersky, 1977; Stevenson, 1978). This theory has been demonstrated experimentally. Jannasch and Pritchard (1972) showed that the addition of non-nutritive particles to low-nutrient cultures of bacteria resulted in significant attachment by bacterla and yielded bacterial density that was higher than in cultures without added particles. The authors concluded that the attachment of bacteria to particles in oligotrophic waters should be beneficial to bacterial growth since the organic materials adsorbed to particles in these waters would result in a more pronounced nutrient gradient than in nutrient-rich waters. In support of this argument, other experimental studies have demonstrated a greater metabolic activity for attached Pseudomonas cells relative to unattached cells (F1etcher, 1979), and an enhanced ability for attachment and survival of Vibrio cells during starvation (Dawson et al., 1981; Kjelleberg et al., 1982).

Despite these results, fleld observations have provided conflicting data on the relative importance of attachment for the growth and survival of planktonic bacterla. Numerous studies have demonstrated that the density or 
biomass of bacteria attached to particles in the plankton is a small percentage of the total bacterla (Hobbie et al., 1972; Wiebe \& Pomeroy, 1972; Jannasch, 1973; Burnison, 1975; Linley \& Field, 1982). In addition, several Investigations have demonstrated a decreasing importance of attached bacteria relative to unattached cells along a transect from a eutrophic environment to an oligotrophic environment (Hanson \& Wiebe, 1977; Bell \& Albright, 1981; Sieburth \& Davis, 1982). This trend is the direct opposite of that predicted by theory. Contrary to the results of these studies, other investigators have Indicated that attached bacteria rather than unattached cells may at times dominate the bacterlal population in the plankton (Jones \& Jannasch, 1959; Seki, 1970, 1971; Paer1, 1975; Goulder, 1977; Rieman, 1978; Wilson \& Stevenson, 1980; Bent \& Goulder, 1981). Furthermore, attached bacterla are often larger than unattached cells thus increasing their Importance (Ferguson \& Rublee, 1976; Zimmerman, 1978; Pedros-Allo \& Brock, 1983).

Activity measurements have been no less confusing. Several studies have shown that most microheterotrophic activity is associated with water passing a 1.0 um filter, presumably an indication of the importance of free-living (unattached) bacterla (Williams, 1970; Derenbach \& Williams, 1974; Azam \& Hodson, 1977; Berman \& Sti1ler, 1977; Cole \& Likens, 1979; Jordan \& Likens, 1980; Schleyer, 1981). Nonetheless, activity of attached bacteria on a "per cel1" basis appears to be greater than that of unattached bacteria (Taga \& Matsuda, 1974; Wiebe \& Smith, 1977; Harvey \& Young, 1980; KIrchman \& Mitchel1, 1982; Paerl \& Merke1, 1982; Pedros-Alio \& Brock, 1983).

This controversy (attachment vs, non-attachment) has clearly focused on the process of attachment for enhancing the growth of bacteria as the major factor affecting the density of bacteria attached to particles in the plankton. Very little consideration has been given to the possibility that the density of attached bacteria may be regulated in part by factors other 
than growth. However, the summed field results seem to suggest that particle attachment may indeed be beneficlal for bacterial growth, but that other factors limit their numbers on particles and are thus responsible for the contradictory nature of the field results. It has been proposed that grazing by bacterivorous organisms may limit the density of bacterla attached to particles in the plankton (Sleburth, 1976; Azam \& Hodson, 1977; Schleyer, 1981; Pedros-Alio \& Brock, 1983), but consideration has only been given to the role which coarse filter-feeding zooplankton play in this process (Sorokin, 1971). Fenchel and Jorgensen (1977) noted a decrease in the number of bacteria colonizing detrital particles in the presence of protozoa but the causative agent was not determined.

Four spectes of microflagellates were examined in this study for their ability to graze bacterfa attached to chitin particles in an effort to explain the high densities of heterotrophic microflagellates on detrital particles in the plankton and their potential for affecting bacterial density on those particles. Two of the four spectes tested efficiently grazed $\underline{P}$. halodurans attached to particles but were unable to effectively graze unattached bacterla. It is concluded from this work that spectes of microflagellates exist which are dependent on attached bacteria for their growth, and which in turn are capable of significantly affecting the density of bacteria attached to particles. 


\section{METHODS AND MATERIALS}

Heterotrophic microflagellates were enriched in seawater samples from Buzzards Bay and from seawater samples and marine snow samples collected in sterile syringes by divers in the Sargasso Sea by adding sterlle rice grains to these samples to provide an energy source for the natural bacterial flora. Clonal cultures of microflagellates were obtained by micropipetting individual flagellates from the enrlchments to flasks containing sterile natural seawater and $0.01 \%$ yeast extract. Successively cloned microflagellates were maintained on a mixed bacterial flora by perlodic transfer to sterile natural seawater with $0.01 \%$ yeast extract.

Four species of microflagellates were studied. Two of the four species employed in this study (Monas sp. and Cryptobia maris) have previously been shown to efficiently graze unattached bacteria (Chapter 3). The other two species were chosen because they showed high affintty for surfaces in cultures. It was hoped that these species might encompass the range of different feeding behaviors of the specles which I presently have in culture.

Monas sp. (clone $\# 2 / 80-2$ ) is a small colorless chrysomonad. Electron microscopy has not been performed on this species to determine the presence or absence of body scales. Therefore, this flagellate may be a species of Paraphysomonas (Hibberd, 1979). Genera within the Order Chrysomonadida have shown a marked ability to graze unattached bacteria (Chapter 3; Davis, 1982; Fenche1, 1982b; Sherr et. a1., 1983). The cell is spherical, 3.0-4.5 $\mu \mathrm{m}$ in diameter, with 2 emergent flagella. The long flagellum $(9.0-11.0 \mu \mathrm{m})$ is anteriorly orlented and is used for locomotion. The short flagellum is 2.0-4.0 $\mu \mathrm{m}$ in length and is usually difficult to see with light microscopy. Monas sp. swims rapidly and smoothly at $80-120 \mu \mathrm{m} \mathrm{sec}{ }^{-1}$, usually in a looping pattern. Species from this order numerically dominated enrichment cultures prepared from seawater samples from the open ocean (see Chapter 1). 
The remaining three specles used in this study are all kinetoplastid flagellates. In comparison to Monas in seawater samples, kinetoplastid flagellates often (but not always) dominated the protozoa enriched from macroscopic detrital aggregates collected from the open ocean (see Chapter 2).

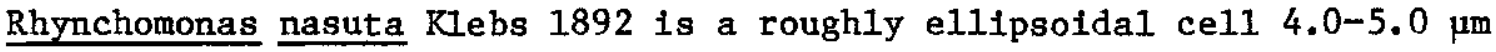
long and 2.0-3.0 $\mathrm{mm}$ wide. The genus is distinguished by the presence of a distinctive proboscis which is the site of ingestion of bacteria (Telkova, 1964; Burze11, 1973). The emergent flagellum is posteriorly orlented and is apparentiy not used for locomotion. This species is a poor swimmer, moving forward very slowly with a jerky motion of the proboscis. However, it moves quite easily and rapidiy along surfaces due to the side-to-side sweeping motion of the proboscis. The emergent flagellum maintains contact with the surface and acts as a skid.

Bodo nanorensis Davis 1982 was described by Davis (1982) from Narragansett Bay, Rhode Island. It is a small, biflagellated kidney bean-shaped bodonid

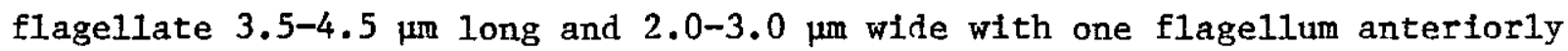

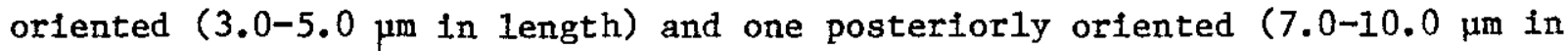
length). Like $\underline{R}$. nasuta, this species is a poor swimmer but is quite capable of moving along a surface. Locomotion is due to the activity of the anterlor flagellum. On surfaces this flagellum sweeps from side to side and the cell moves forward with a jerky motion. The trailing flagellum acts as a skid. Cryptobia marls. is also biflagellated with one anteriorly orfented flage1lum (7.0-10.0 $\mu \mathrm{m}$ in length) which 1s largely responsible for $1 \mathrm{ts}$ locomotion, and one posteriorly orfented flagellum which is attached to the cell along the length of the body. This latter flagellum extends 4.0-5.0 $\mu \mathrm{m}$ beyond the end of the cell and is used as a skid when the cell is in contact with surfaces. The flagellate is teardrop-shaped, 3.5-4.5 $\mu \mathrm{m}$ wide and 5.5-6.5 $\mu \mathrm{m}$ 1ong. This species was described by Davis (1982) from the Sargasso Sea, 
Gulf Stream and Narragansett Bay, Rhode Island and is unique in that it is shows good locomotion both in water and along surfaces. Its swimming speed is 10-20 $\mathrm{m} \mathrm{sec} \mathrm{se}^{-1}$. Movement in the water and along surfaces is due to the action of the anterior flagellum.

The bacterium Pseudomonas halodurans was used to test the ability of the microflagellates to graze suspended bacteria and bacteria attached to particles. Purified chitin (P-L Blochemicals, Milwaukee, WI) was used as a source of particles. Chitin chips were ground in a Polytron tissue grinder (Brinkman Instruments, Westbury, NY), sieved through a $40 \mu m$ mesh screen and caught on a $20 \mu \mathrm{m}$ mesh screen. All grinding and sieving was performed dry. This procedure yielded predominantly sheet-like particles of $400-1600 \mu^{2}$.

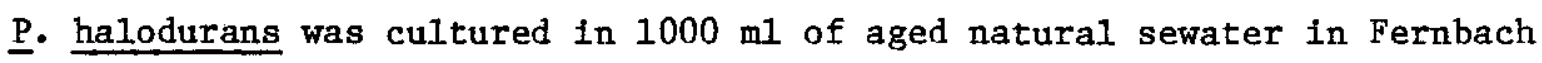
flasks under four conditions. Five or $50 \mathrm{mg} 1^{-1}$ of yeast extract was added to two flasks each. Chitin particles were added to one of the $5 \mathrm{mg} 1^{-1}$ and $50 \mathrm{mg} 1^{-1}$ flasks at a concentration of $2-3 \times 10^{3}$ particles $\mathrm{ml}^{-1}$. The flasks were sterilized and then fnoculated with $\underline{P}$. halodurans. The cultures were placed on a rotary shaker $(100 \mathrm{r} . \mathrm{p} . \mathrm{m}$.$) at 20^{\circ} \mathrm{C}$ in the dark for 6 days. Antibiotics were then added to each flask at a concentration of $60 \mathrm{mg} 1^{-1}$ penicilien and $30 \mathrm{mg} 1^{-1}$ streptomycin to stop bacterial growth. The four treatments were then sp1it into four equal parts and each aliquot was inoculated with one of the four microflagellates species. The flasks were placed back on the rotary shaker at $20^{\circ} \mathrm{C}$ in the dark.

Samples were taken periodically and counted for unattached and attached bacteria and microflagellates. Samples were preserved with filtered glutaraldehyde at a final concentration of $1.0 \%$. Bacterla and microflagellates were enumerated by the acridine orange epifluorescence technique (Watson et al., 1977). Unattached bacteria were counted on $0.2 \mu \mathrm{m}$ pore size pre-stained Nuclepore filters (Hobbie et a1., 1977). Attached 
bacteria were counted on $5.0 \mu \mathrm{m}$ pore size Nuclepore filters. Stalned preparations were rinsed with approximately $2 \mathrm{ml}$ of filtered distilled water to remove unattached cells. Bacteria attached to each particle were counted and this number was doubled to account for bacterla on the side of the particle facing the filter. Since most particles were flat sheets this procedure provided a good estimate of the number of bacteria per particle. Microflagellates were counted on $0.8 \mu \mathrm{m}$ pore size Nuclepore filters. The number of microflagellates situated on particles was also counted, and this number was doubled as for the attached bacteria. 
RESULTS AND DISCUSSION

The ability of the four microflagellate species to graze attached and unattached bacteria is shown in Figures 4.2 and 4.3 which shows the concentration of attached and unattached bacteria in the culture vessels containing chitin and $5 \mathrm{mg} 1^{-1}$ or $50 \mathrm{mg} 1^{-1}$ yeast extract. The initial density of unattached bacteria was approximately $5 \times 10^{7} \mathrm{ml}^{-1}$ in the $50 \mathrm{mg}$ $1^{-1}$ vessel and $4 \times 10^{6} \mathrm{ml}^{-1}$ in the $5 \mathrm{mg} 1^{-1}$ vessel. The density of attached bacteria was similar in both vessels at approximately $6-8 \times 10^{5}$ $\mathrm{ml}^{-1}$. The density of attached bacteria was determined by counting the number of bacterla per particle and multiplying by the number of particles $\mathrm{ml}^{-1}$. Inftial bacterial densities in culture vessels without chitin particles were 1ndistinguishable from inftial densities in vessels with chitin particles. The coefficients of variation for counts of attached bacteria, unattached bacteria and protozoa were $54 \%, 11 \%$ and $15 \%$, respectively. The large coefficient of variation for the counts of attached bacteria was due largely to the variable size of the particles $\left(400-1600 \mathrm{\mu m}^{2}\right.$ sheets). The density of attached bacterla was similar in the $5 \mathrm{mg} 1^{-1}$ and $50 \mathrm{mg} 1^{-1}$ vessels and was always less than the density of unattached bacterla inftially due to the limited attachment space on the particles.

It is clear from Figures 4.2 and 4.3 that the Monas sp. and Cryptobia maris showed a marked ability to graze unattached bacteria but no ability to graze attached bacterla. As previously mentioned, other chrysomonads have been shown to efficiently graze free-living bacteria (Davis, 1982; Fenchel, 1982b; Sherr et al., 1983). The species of Monas used in this study reduced the density of unattached bacteria to $4-5 \times 10^{5} \mathrm{ml}^{-1}$ in vessels containing chitin particles. Attached bacteria became an important portion of the total number of bacteria in these vessels due to the removal of unattached cells by microflagellate grazing. 
Figure 4.2. Density of bacteria in the two culture treatments with chitin particles in the presence of protozoan grazing. (0) Unattached bacteria in the $50 \mathrm{mg} 1^{-1}+$ chitin vessel. ( $)$ Attached bacteria in the $50 \mathrm{mg} 1^{-1}+$ chitin vessel. (D) Unattached bacteria in the $5 \mathrm{mg} 1^{-1}+$ chitin vessel. (A) Attached bacteria in the $5 \mathrm{mg} 1^{-1}+$ chitin vessel. 


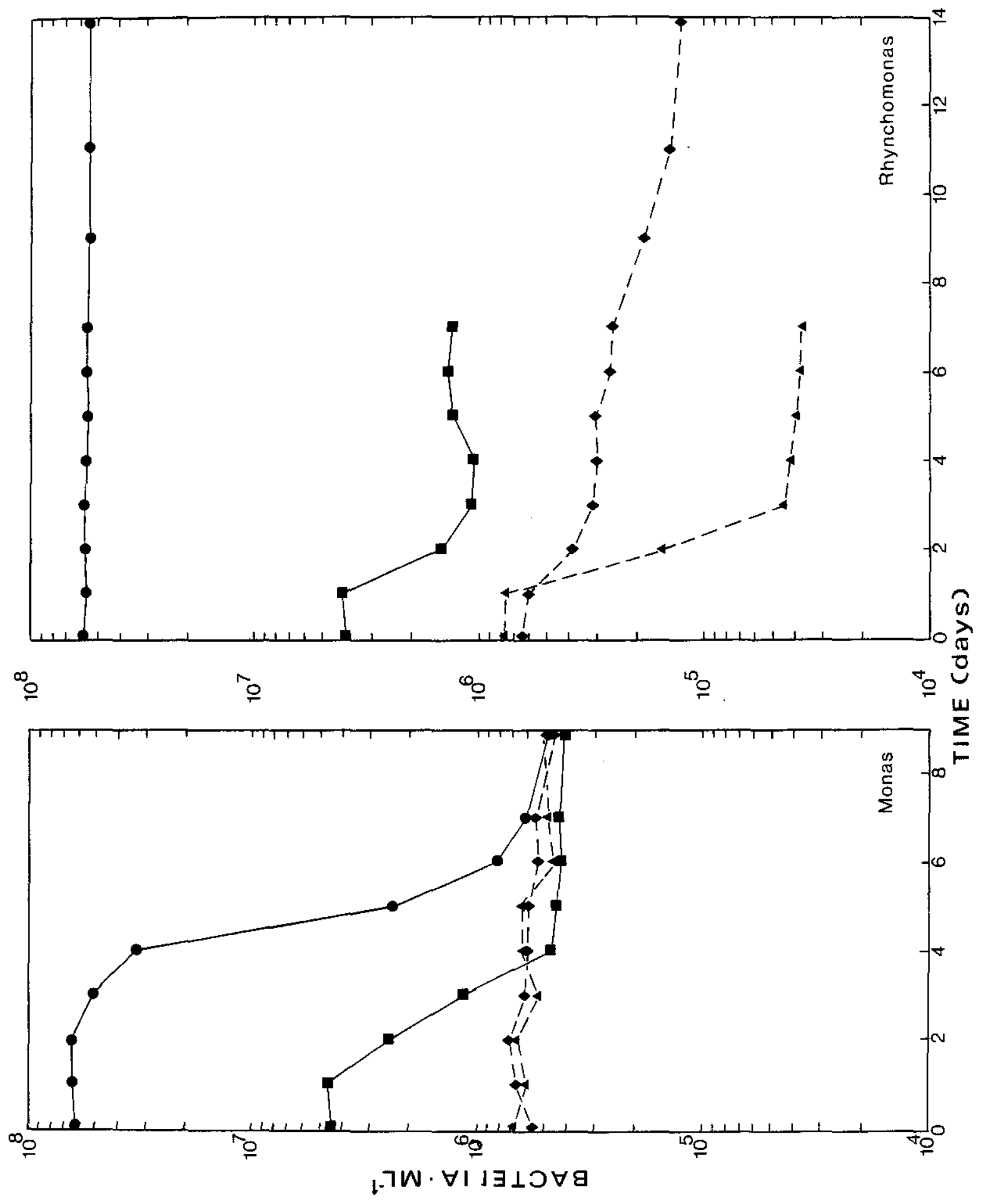


Figure 4.3. Density of bacteria in the two culture treatments with chitin particles in the presence of protozoan grazing. (0) Unattached bacteria in the $50 \mathrm{mg} 1^{-1}+$ chitin vessel. ( ) Attached bacteria in the $50 \mathrm{mg} 1^{-1}+$ chitin vessel. (D) Unattached bacteria in the $5 \mathrm{mg} 1^{-1}+\operatorname{chitin}$ vessel. (A) Attached bacteria in the $5 \mathrm{mg} 1^{-1}+$ chitin vessel. 


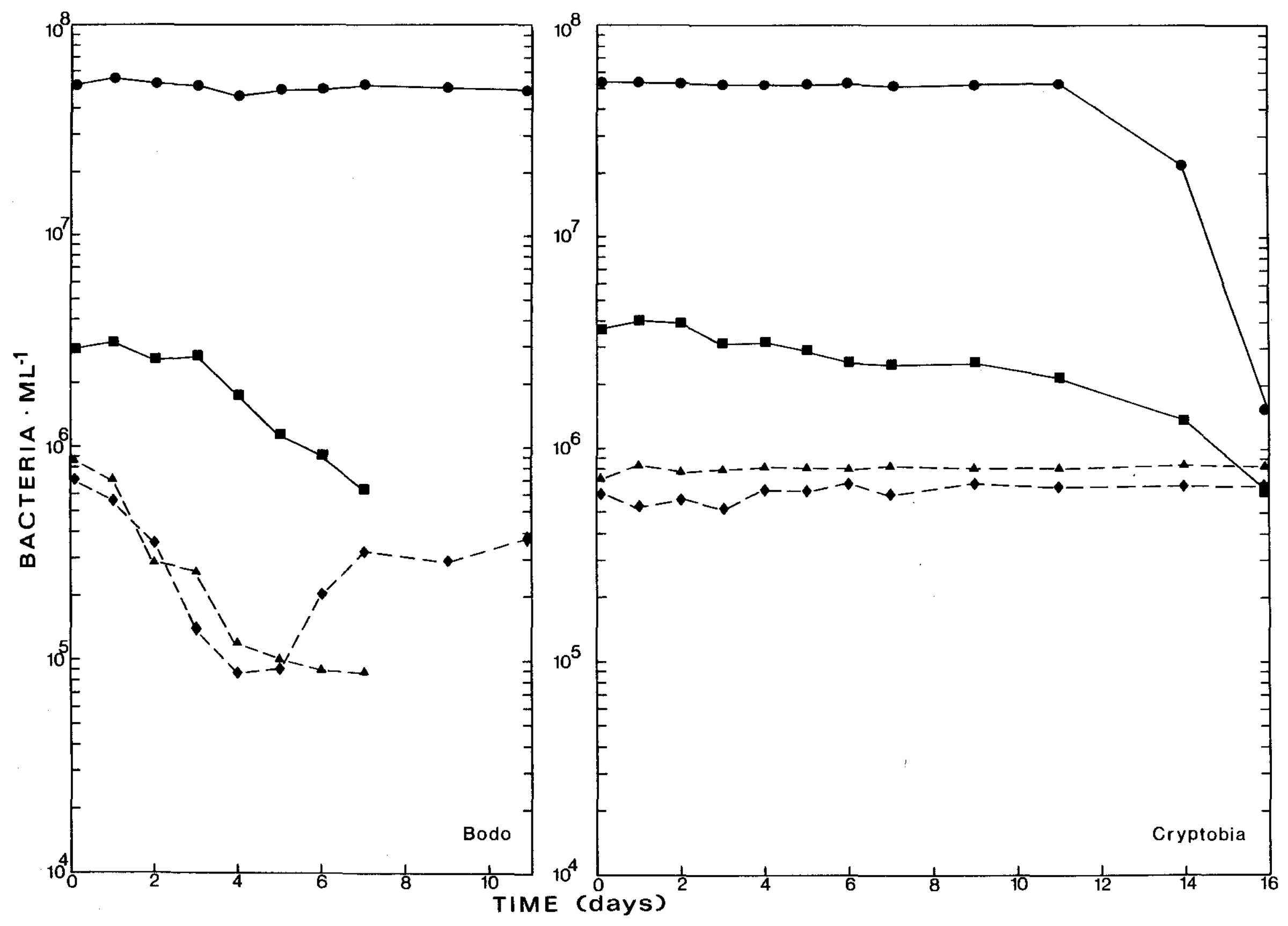


Cryptobia also reduced the density of unattached $\underline{P}$. halodurans. This species underwent a relatively long (6-7 days) lag before initiating exponential growth and attained a slower maximum specific growth rate than Monas sp.. This behavior resulted in a delay in the decrease of bacterial numbers in Figure $4.3 \mathrm{~b}$. The density of unattached bacteria was reduced to $6-16 \times 10^{5} \mathrm{ml}^{-1}$ at the end of the sampling period whereas the density of attached bacteria remained unchanged.

In contrast to Monas and Cryptobia, Rhynchomonas nasuta and Bodo nanorensis both showed an ability to graze $\underline{P}$. halodurans attached to chitin part1cles. Rhynchomonas (Figure 4.2b) reduced the number of attached bacteria to a lower density in the $5 \mathrm{mg} 1^{-1}$ vessel than in the $50 \mathrm{mg} 1^{-1}$ vessel. The density of attached bacteria in the $5 \mathrm{mg} 1^{-1}$ vessel reached a minimum of $3 \times 10^{4} \mathrm{ml}^{-1}$. In the $50 \mathrm{mg} 1^{-1}$ vessel the number of attached bacteria decreased steadily but had not reached a plateau by the end of the sampling period. The slower decrease in the density of attached bacteria in the $50 \mathrm{mg}$ $1^{-1}$ vessel may be a result of the attachment of bacterla from the large pool of unattached cells. The density of unattached bacteria in the $5 \mathrm{mg} 1^{-1}$ vessel decreased from $3 \times 10^{6}$ to $1 \times 10^{6}$ bacterla ml ${ }^{-1}$ during the experiment. It is possible that grazing of Rhynchomonas directly on unattached bacteria can account for this decrease. However, a more 1ikely explanation is the adsorption or attachment of bacteria to surfaces, and subsequent grazing of these newly attached bacteria. This hypothesis is supported by the observation that the much denser concentration of unattached bacteria in the $50 \mathrm{mg} 1^{-1}$ vessel was not effectively grazed by Rhynchomonas.

The density of attached bacteria was also reduced by Bodo (Figure 4.3a). The densities of attached bacteria reached similar minima ( $8 \times 10^{4}$ bacteria $\mathrm{ml}^{-1}$ ) in both vessels after 4-5 days of grazing. The number of attached bacteria subsequently increased in the $50 \mathrm{mg} 1^{-1}$ vessel, presumably a 
combined result of adsorption or attachment of bacteria and the cessation of protozoan growth observed at this time. The increase in the number of attached bacteria in this vessel is an indication that attachment of bacteria from the large pool of unattached cells was taking place. The density of unattached bacteria decreased in the $5 \mathrm{mg} 1^{-1}$ vesse1 as with Rhynchomonas, but direct utilization of unattached bacteria by the microflagellate is unlikely since this species was also unable to effectively graze the high density of unattached bacteria in the $50 \mathrm{mg} 1^{-1}$ vessel.

The density of attached bacteria is shown in Figure 4.4 as the number of bacterla particle ${ }^{-1}$ in the culture vessels containing chitin particles. Initial densities of attached bacteria ranged from 86 to 550 bacterla particle $\mathrm{e}^{-1}$ with average density being approximately 200 to 350 bacteria particle $e^{-1}$. The efficiency of Rhynchomonas and Bodo at removing bacterla from the chitin particles is shown by the decreases in the density of attached cells. Bacterlal density in the $5 \mathrm{mg}^{-1}$ vessel was reduced to $10-30$ bacterfa particle $\mathrm{e}^{-1}$ which roughly corresponds to $1-3$ bacteria per $100 \mu^{2}$ of particle surface area. These densities are commensurate with the densities of bacterla observed on particles in water samples from a number of environments (Fenche1 \& Jorgensen, 1977; Kirchman \& Mitche11, 1982). Bacterial densities on particles in the $50 \mathrm{mg}^{-1}$ vessels were not as severely Impacted by Rhynchomonas and Bodo grazing. As previously mentioned, this was probably due to replacement of the grazed cells by newly attached bacteria.

The results described thus far are shown qualitatively in epifluorescence photomicrographs of chitin particles at the time of inoculation with Bodo, and two days and four days after inoculation (Figure 4.5). Microflagellates were abundant on particles at day 2 and had significantly affected bacterial density. Particles were nearly devold of bacteria following four days of 
Figure 4.4. The density of bacteria attached to chitin particles in the presence of microflagellate grazing expressed as the number of bacterta per partlcle.

\author{
Monas = Monas sp. \\ Cryp. = Cryptobia maris \\ Bodo $=$ Bodo nanorensis \\ Rhyn. = Rhynchomonas nasuta
}




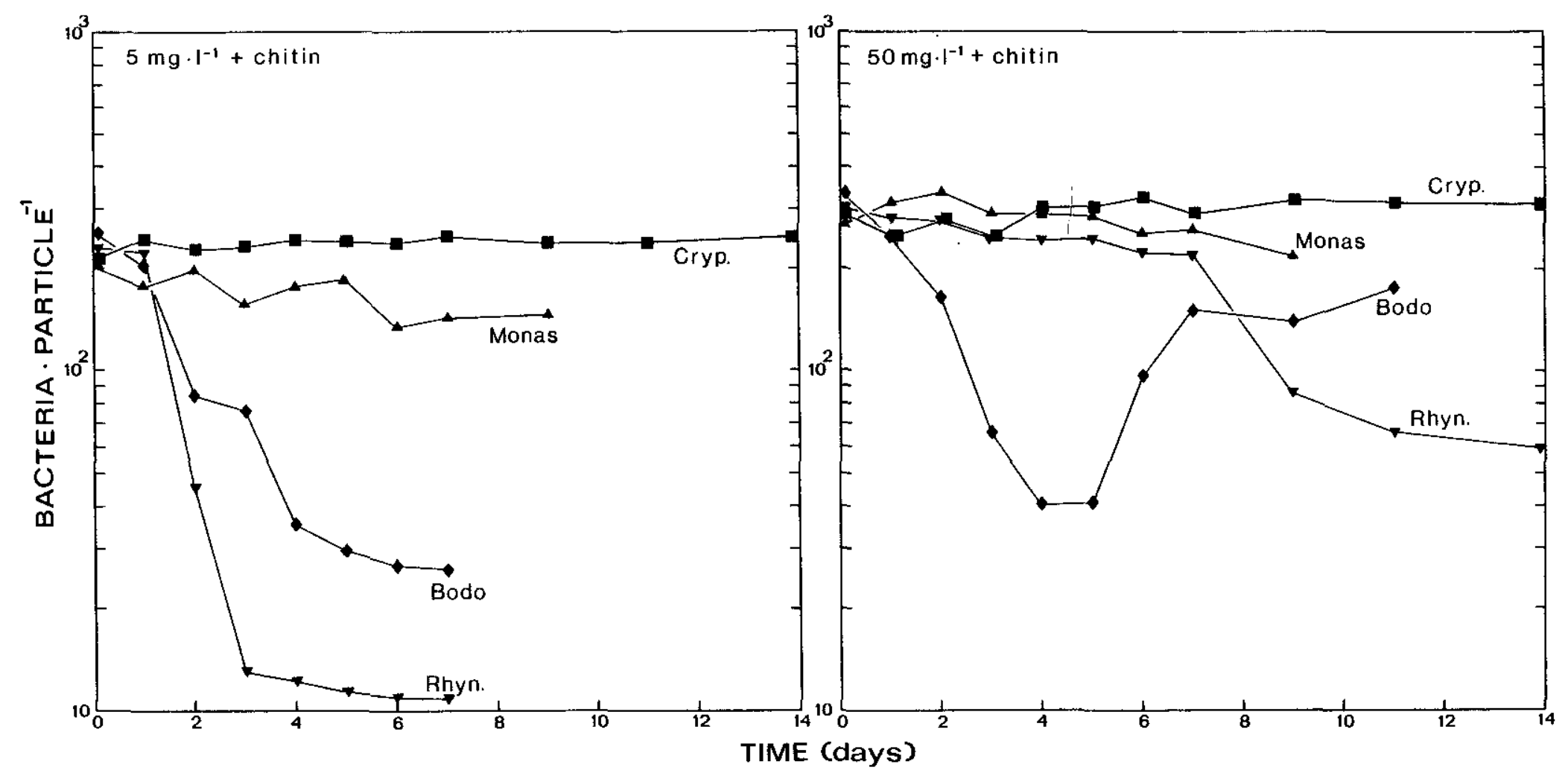


Figure 4.5. Eplfluorescence photomicrographs showing the grazing of bacteria attached to chitin particles by the heterotrophic microflagellate Bodo nanorensis. A.) Attached bacteria at the time of inoculation with B. nanorensis. B.) Attached bacteria and microflagellates after two days of grazing. C.) Chitin particles after four days of microflagellate grazing. Particles are nearly devoid of bacteria. 


\section{$-156 a=$}
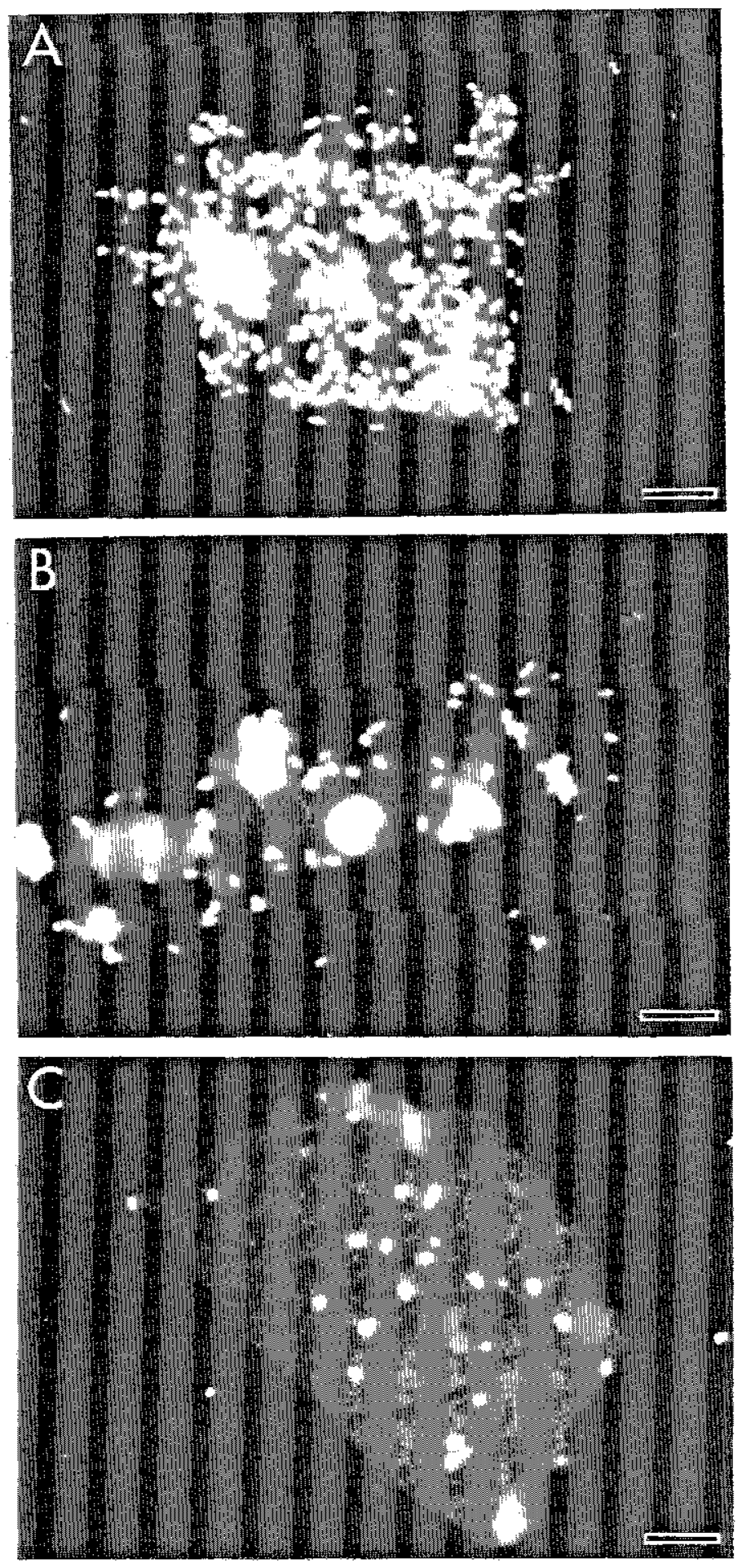
flagellate grazing. Microflagellate density had also begun to decrease by the fourth day.

The percentage of microflagellates assoclated with (i.e. situated on) particles was recorded during the epifluorescence counts (Figure 4.6). These percentages may significantly underestimate the affinity of microflagellates for particles since microflagellates may have become dislodged durlng sample preparation. Nevertheless, there is a clear trend for particle assoclation with Rhynchomonas and Bodo. Even in the $50 \mathrm{mg} 1^{-1}$ vessels where unattached bacteria are nearly two orders of magnitude more abundant, a relatively large proportion of the population of these two flagellates were observed on particles. Rhynchomonas showed a steady increase in the percentage of Individuals on particles up to a maximum of $65-75 \%$ and remained stable at that maximum. Bodo showed the opposite trend with $65-75 \%$ of the individuals associated with particles shortly after inoculation, decreasing to $20-30 \%$ and then increasing somewhat over the course of the experiment. Densities of Monas and Cryptobla on particles remained fairly low throughout the experiment (generally $<25 \%$ ).

Growth of the four microflagellate species in the four culture treatments (5 mg $1^{-1}$ and $50 \mathrm{mg} 1^{-1}$ yeast extract, with and without chitin particles) 1s shown in Figures 4.7 and 4.8. Monas (Figure 4.7a) and Cryptobia (Figure 4.8b) showed no significant increase in the growth rate or the maximum population density obtained due to the presence or absence of chitin particles. Maximum abundances of microflagellates in the $5 \mathrm{mg} 1^{-1}$ vessels with and without chitin were one order of magnitude less than the maximum abundances in the $50 \mathrm{mg} 1^{-1}$ vessels for these species. This result reflects the differences in the density of unattached bacteria between the $5 \mathrm{mg} 1^{-1}$ and $50 \mathrm{mg} 1^{-1}$ vessels. Maxima of microflagellate abundances for these two species coincided with minima of the number of unattached bacteria. 
Figure 4.6. Percentage of protozoa occurring on chitin particles as shown by epifluorescence microscopy.

$$
\begin{aligned}
& \text { Monas }=\text { Monas } \mathrm{sp} . \\
& \text { Cryp. = Cryptobia maris } \\
& \text { Bodo = Bodo nanorensis } \\
& \text { Rhyn. = Rhynchomonas nasuta }
\end{aligned}
$$




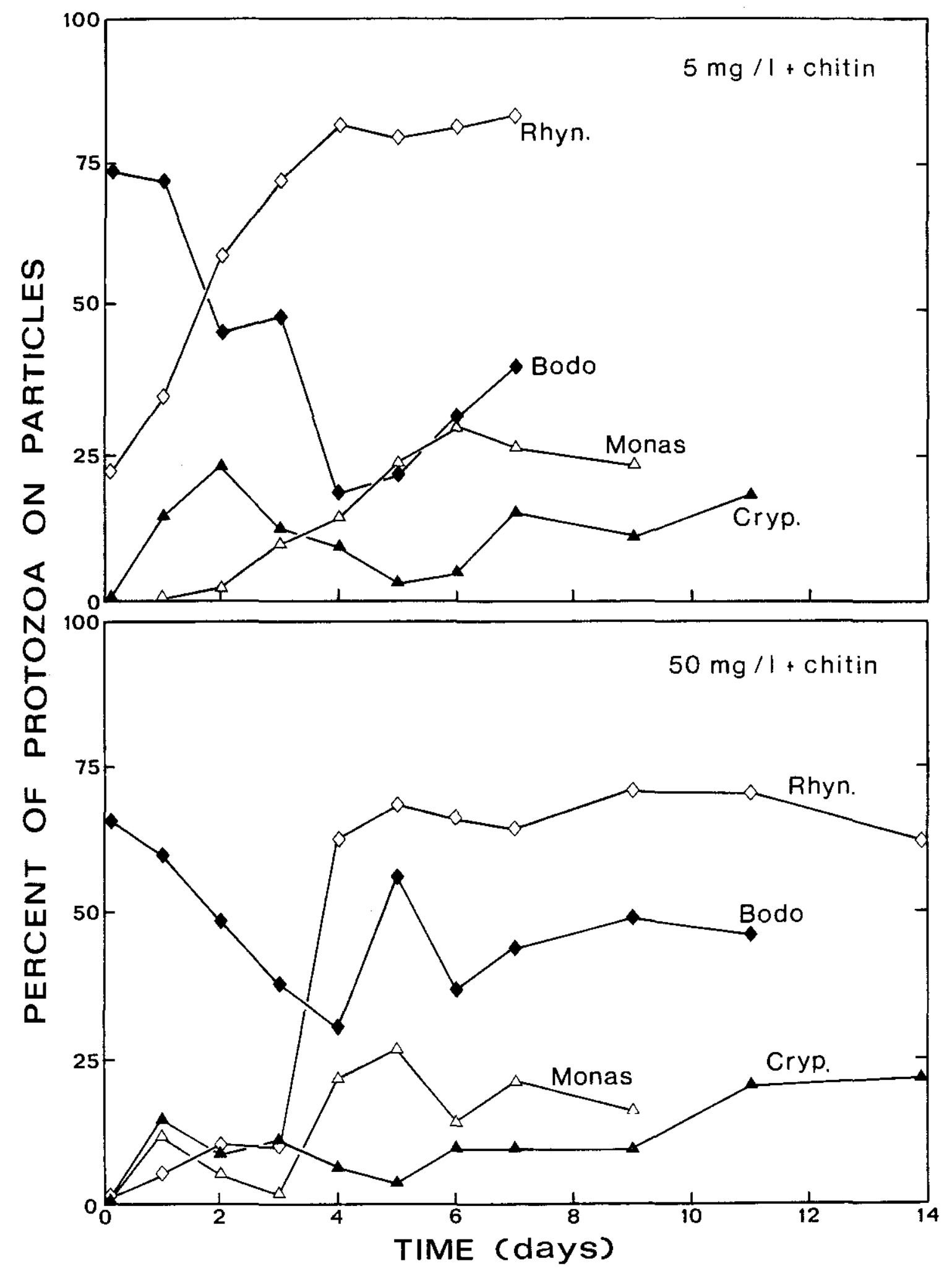


Figure 4.7. Growth of the microflagellates Monas sp. and Rhynchomonas nasuta on Pseudomonas halodurans grown at two concentrations of yeast extract ( $5 \mathrm{mg} 1^{-1}$ and $50 \mathrm{mg} 1^{-1}$ ) and in the presence and absence of chitin particles at these concentrations.

( $) 5 \mathrm{mg}^{-1}$ yeast extract

(A) $5 \mathrm{mg} 1^{-1}$ yeast extract + chitin

(I) $50 \mathrm{mg}^{-1}$ yeast extract

(O) $50 \mathrm{mg} 1^{-1}$ yeast extract + chitin 


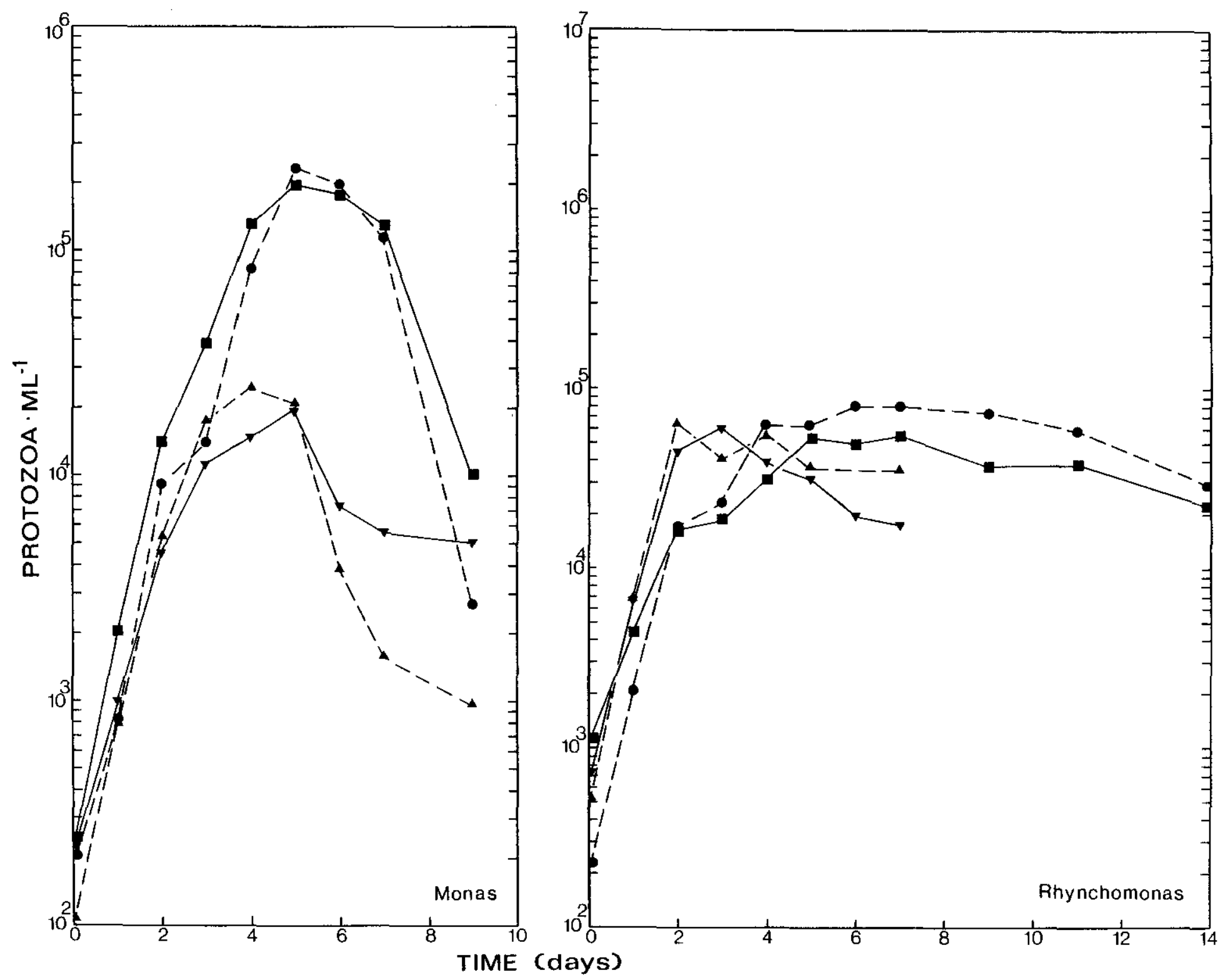


Figure 4.8. Growth of the microflagellates Bodo nanorensis and Cryptobia maris on Pseudomonas halodurans grown at two concentrations of yeast extract ( $5 \mathrm{mg} 1^{-1}$ and $50 \mathrm{mg} 1^{-1}$ ) and in the presence and absence of chitin particles at these concentrations.

( $) 5 \mathrm{mg}^{-1}$ yeast extract

(A) $5 \mathrm{mg} 1^{-1}$ yeast extract + chitin

(D) $50 \mathrm{mg} 1^{-1}$ yeast extract

(อ) $50 \mathrm{mg}^{-1}$ yeast extract + chitin 


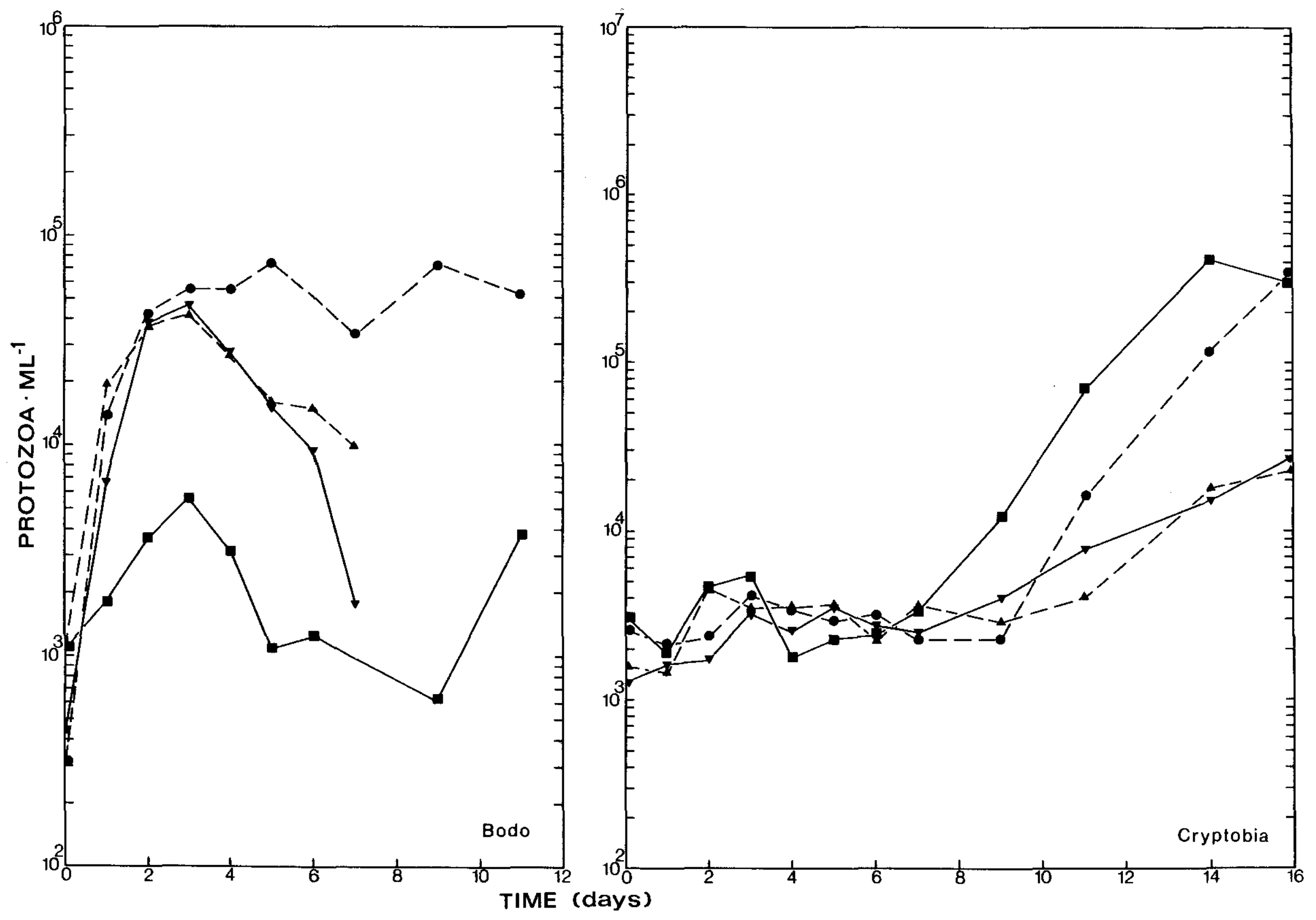


Growth of Rhynchomonas (Figure 4.7b) and Bodo (Figure 4.8a) differed markedly from that observed for Monas and Cryptobia. Rhynchomonas showed simflar growth rates and reached similar maximum densities in all four treatments. Therefore, growth of this species cannot be correlated directly with the density of unattached bacteria or with the presence of chitin particles. It is possible that growth on the walls of the culture flasks may explain this pattern. The density of unattached bacteria decreased slightly In the $5 \mathrm{mg} 1^{-1}$ vessels, but grazing of microflagellates directly on unattached bacterla is unlikely since the density of unattached bacteria in the $50 \mathrm{mg} 1^{-1}$ vessels did not decrease, and did not result in a greater maximum abundance of microflagellates.

The growth rate and maximum abundance of Bodo were similar in all treatments except the vessel containing $50 \mathrm{mg}^{-1}$ yeast extract without chitin. Maximum abundance in the latter treatment was less than growth in the other treatments. Maxima in the abundance of Bodo in the treatments with chitin particles were observed at the same time as minima in the abundance of attached bacteria (Figure 4.3a). Growth of Bodo in the $5 \mathrm{mg} 1^{-1}$ vessel without chitin particles was correlated with the disappearance of aggregated bacteria in this vesse1. Approximately $50 \%$ of the bacteria in the $5 \mathrm{mg} 1^{-1}$ vessels without chitin occurred in aggregates of approximately 10-200 bacteria aggregate ${ }^{-1}$. Aggregated cells in this treatment were poorly grazed by Monas and Cryptobia but they were reduced below the 11mit of detection $\left(4 \times 10^{4}\right.$ $\mathrm{ml}^{-1}$ ) within three days by Bodo and Rhynchomonas. The cessation of growth for Bodo in this treatment colncided with the disappearance of aggregated cells. Significant aggregation was not observed in the $50 \mathrm{mg} 1^{-1}$ vessel without chitin and the growth of Bodo in this vessel was less than growth observed in the other treatments.

The two types of microflagellate feeding behavior observed in this study 
are summarized in Figure 4.9. This Figure compares changes in the density of bacterla and protozoa in the $50 \mathrm{mg} 1^{-1}$ vessels with chitin particles for Monas sp. and Bodo nanorensis. Monas showed a rapid increase in its density with a concomitant decrease in the abundance of unattached bacteria. Protozoan density reached a maximum and then decreased rapidly as the bacterial density reached a minimum of $6 \times 10^{5}$ bacteria $\mathrm{ml}^{-1}$. The number of attached bacterla remalned unchanged. In contrast, the increase in the density of Bodo coincided with a decrease in the density of attached bacteria, even though the absolute number of attached bacteria $\mathrm{ml}^{-1}$ was nearly two orders of magnitude less than the number of unattached bacterla. The maximum density of Bodo occurred as the number of attached bacterla reached a minimum. Unlike Monas, the Bodo population did not drop precipitously after reaching a maximum. It is hypothesized that the population was sustained by attachment of bacteria from the large pool of unattached cells.

The ecological implications of these two feeding strategles are exemplified by a comparison of growth of Monas sp. and Bodo nanorensis in the treatments containing $5 \mathrm{mg} 1^{-1}$ yeast extract and chitin particles or $50 \mathrm{mg}$ $1^{-1}$ yeast extract without chitin particles (Figure 4.10). Monas had a maximum population density that was an order of magnitude greater in the $50 \mathrm{mg}$ $1^{-1}$ vessel w1thout chitin (because there were $10 x$ as many unattached bacteria present in this treatment). In contrast, Bodo reached a maximum population density in the $5 \mathrm{mg} 1^{-1}$ vessel with chitin that was $6 \mathrm{x}$ greater than its density in the $50 \mathrm{mg} 1^{-1}$ without chitin. The presence of particles (and their attached bacterla) allowed more growth of the microflagellate despite the lower total bacterial density.

The results of this study may have important implications for microbial populations in plankton communities. The ability of some microflagellate species to graze attached bacteria may explain the affinity of these 
Figure 4.9. Changes in the density of microflagellates and bacteria in the culture vessels containing $50 \mathrm{mg} 1^{-1}$ yeast extract and chitin particles for the microflagellates Monas sp. and Bodo nanorensis. 


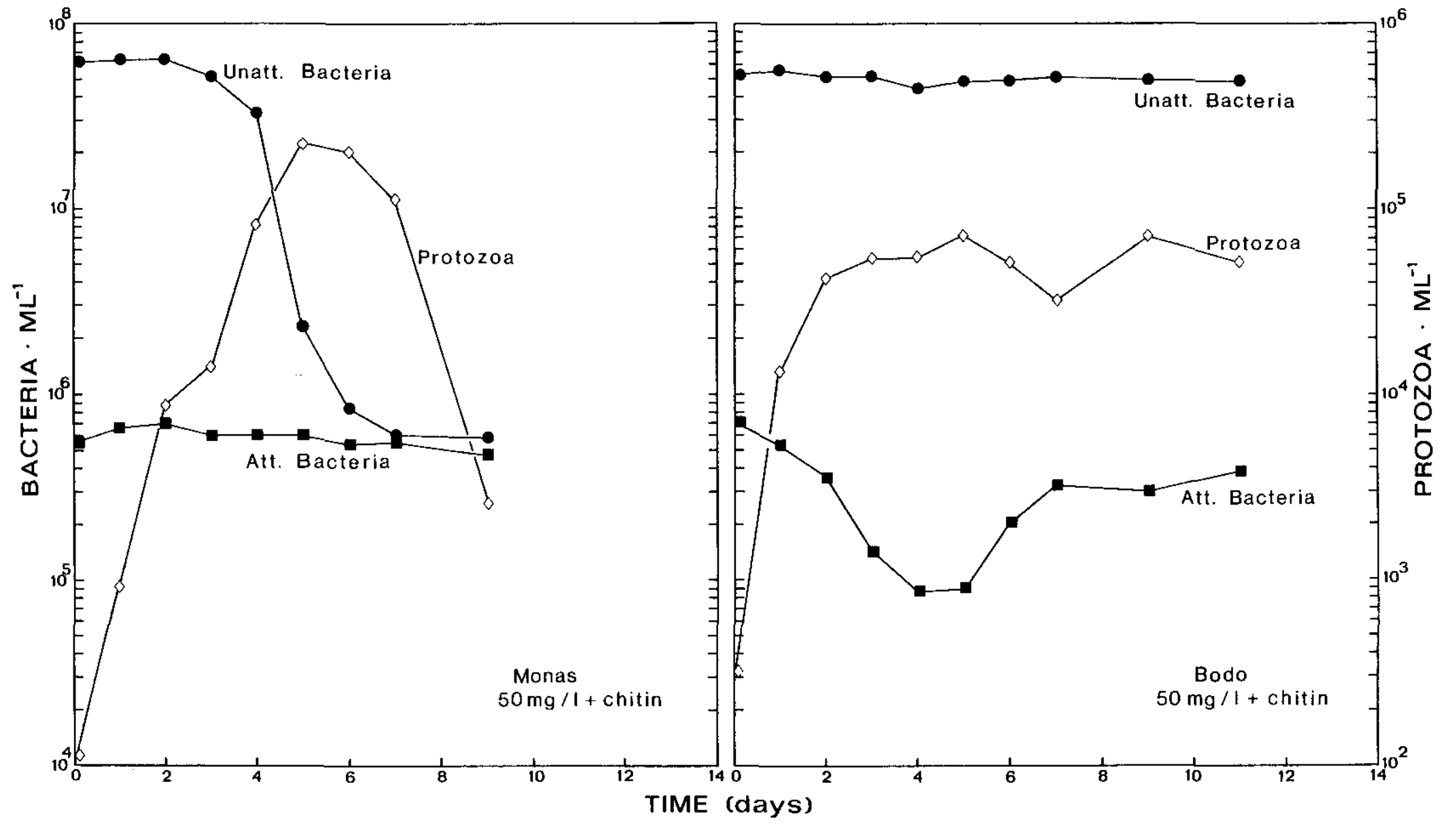


Figure 4.10. Growth of Monas sp. and Bodo nanorensis on Pseudomonas halodurans grown on $5 \mathrm{mg} 1^{-1}$ yeast extract in the presence of chitin particles or on $50 \mathrm{mg} 1^{-1}$ yeast extract in the absence of chitin particles. 

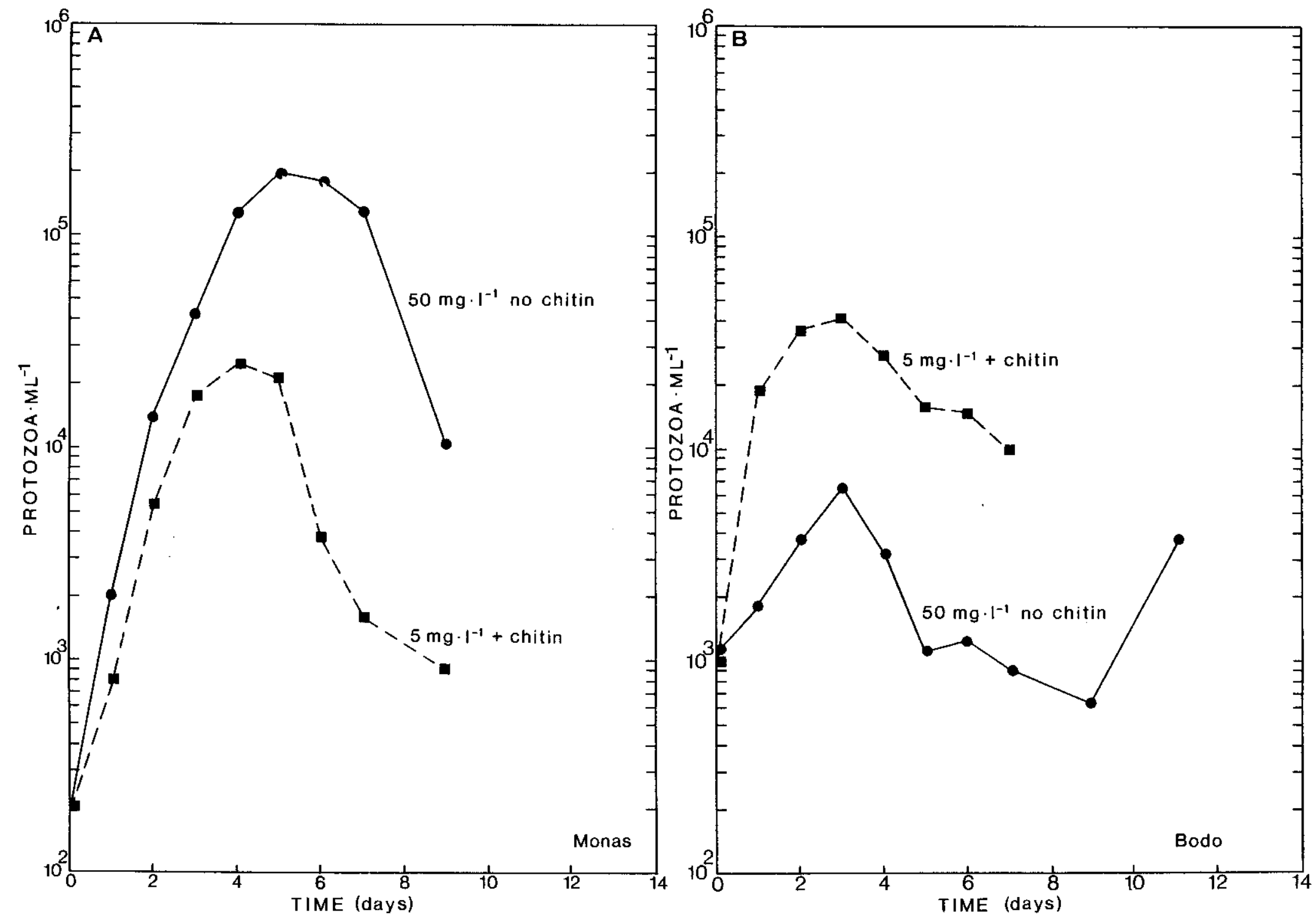
populations for particles. Microflagellate densities which are highly elevated relative to densities in the surrounding water have been observed on macroscopic (Caron et a1., 1982; Davoll, 1983) and microscopic (Figure 4.1; Pomeroy \& Johannes, 1968; Fenche1, 1982d; Pomeroy, 1983) detrital particles. These high densities may be explained in part by growth of microflagellates on attached bacterla. The pelagic existence of these species of microflagellates may in turn be explained by their assoclation with suspended particles. Bodo nanorensis and Rhynchomonas nasuta showed a limited ability to graze unattached cells. It is doubtful that these species could compete successively with species such as Monas for unattached bacterla in the open ocean (see Chapter 3). Rather, their growth is probably linked to their existence on particles in the plankton. Therefore, the distribution of particles which provide a surface for bacterial attachment, and the extent of colonization of these particles by bacteria, may be important factors for the pelagic existence of these surface-associated species of microflagellates.

The importance of heterotrophic microflagellates as consumers of unattached bacteria is now well-recognized (Chapter 3; Haas \& Webb, 1979; Davis, 1982; Fenche1, 1982 b; Sleburth \& Davis, 1982; Azam et a1., 1983). Their activity as bacterial grazers is such that they have been proposed as the main factor controlling the density of suspended bacteria in the plankton. Very little consideration has been given to the possibility that they may also be able to reduce the number of attached or aggregated bacteria. In fact, the converse is true. Studies have shown that in the presence of microflagellates which are capable of grazing unattached bacteria, the relative importance of attached or aggregated bacteria increased due to the removal of unattached/unaggregated cells (Gude, 1979; Robertson et al., 1982). Similar results were observed in this study (Figure 4.2a and 4.3b). However, the results of this study also suggest that in the presence of 
certain surface-associated species of microflagellates the density and activity of attached bacteria might also be affected by the grazing of these protozoa. The densities of bacterla remaining attached to chitin particles following exposure to mfcroflagellate grazing were similar to bacterlal densities which have been observed on particles collected from a variety of aquatic environments (Fenche1 \& Jorgensen, 1977; KIrchman \& Mitche11, 1982). Thus it is possible that microflagellate grazing could account for the generally low densities of bacterla attached to particles in the plankton.

It is not intent of this study to suggest that grazing by heterotrophic microflagellates is the only factor affecting the density of bacteria on particles in the plankton. Other important considerations may include the density of particles in the plankton, the age of the particles (which will determine the degree of colonization), the chemical composition of the material, grazing by larger zooplankton, and also physical processes such as sedimentation. Also, the results do not provide information on the ability of microflagellates to graze bacteria which are attached by specialized structures or secretions such as stalks, mucllagenous materlals or fimbraie. However, this investigation has demonstrated that microflagellate grazing should at least be considered as a potential explanation to conflicting field data on the importance of attached bacteria.

This predator-prey relationship complicates the already confused issue of the importance of attachment for bacterlal growth in plankton communities. If attachment is an important survival tactic for bacteria, then the density of attached bacterla must be a balance between attachment and growth of bacterfa on one hand and removal by protozoan grazers on the other hand. Thus the importance of bacteria attached to particles relative to free-living bacteria in the plankton is a dynamic situation dictated by the relative contribution of these processes at a particular place and time. 
Microflagellates were shown to selectively graze attached bacteria in this study even in the presence of a dense population of unattached bacterla. This behavior may be energetically more efficient for these species since attached bacteria may provide microenvironments of elevated bacterial biomass in comparison to free-living bacterial blomass. The importance of these protozoa in plankton communities requires clarification. 
REFERENCES

Azam, F., T. Fenchel, J.G. Field, J.S. Gray, L.A. Meyer-Reil \& F. Thingstad. 1983. The ecological role of water-column microbes in the sea. Mar. Ecol. Prog. Ser. 10: 257-263.

Azam, F. \& R.E. Hodson. 1977. Size distribution and activity of marine microheterotrophs. Iimno1. Oceanogr. 22: 492-501.

Bell, C.R. \& L.J. Albright. 1981. Attached and free-floating bacterla in the Fraser River Estuary, British Columbia, Canada. Mar. Eco1. Progr. Ser. $6: 317-327$.

Bent, E.J. \& R. Goulder. 1981. Planktonic bacteria in the Humber Estuary; Seasonal variation in population density and heterotrophic activity. Mar. Biol. 62: 35-45.

Berman, T. \& M. Stiller. 1977. Simultaneous measurement of phosphorus and carbon uptake in Lake Klnneret by multiple isotope labeling and differential filtration. Microb. Eco1. 3: 279-288.

Burnison, B.K. 1975. Microblal ATP studies. Verh. Int. Verein. Limno1. 19: 286-290.

Burze11, L.A. 1973. Observations on the proboscls-cytopharynx complex and flagella of Rhynchomonas metabolita Pshenin, 1964 (Zoomastigophorea: Bodonfdae). J. Protozool. 20: 385-393.

Caron, D.A., P.G. Davis, L.P. Madin \& J.McN. Sieburth. 1982. Heterotrophic bacteria and bacterivorous protozoa in oceanic macroaggregates. Sclence 218: $795-797$.

Cole, J.J. \& G.E. Likens. 1979. Measurements of mineralization of phytoplankton detritus in an oligotrophic lake. Limnol. Oceanogr. 24: $541-547$.

Davis, P.G. 1982. Bacterivorous flagellates in marine waters. Ph.D. Thesis, 
University of Rhode Island. 218pp.

Davis, P.G. \& J.McN. Sieburth. 1982. Differentiation of the photosynthetic and heterotrophic populations of nanoplankters by epifluorescence microscopy. Ann. Inst. oceanogr., Parls 58(S): 249-259.

Davol1, P.J. 1983. Life history and community structure of marine snow aggregates from Monterey Bay. EOS, Trans. Amer. Geophys. Union 64: 1020 (Abstr.).

Dawson, M.P., B.A. Humphrey \& K.C. Marsha11. 1981. Adhesion: A tactic In the survival strategy of a marine vibrio during starvation. Current Microbiol. 6: 195-199.

Derenbach, J.B. \& P.J.1eB. W111lams. 1974. Autotrophic and bacterlal production: Fractionation of plankton populations by differential filtration of samples from the English Channel. Mar. Biol. 25: 263-269. Fenchel, T. 1982a. Ecology of heterotrophic microflagellates. I. Some important forms and their functional morphology. Mar. Ecol. Prog. Ser. 8: $211-223$.

Fenche1, T. 1982b. Ecology of heterotrophic microflagellates. II. Bloenergetics and growth. Mar. Ecol. Prog. Ser. 8: 225-231.

Fenche1, T. 1982d. Ecology of heterotrophic microflagellates. IV. Quantitative occurrence and Importance as bacterial consumers. Mar. Ecol. Prog. Ser. 9: 35-42.

Fenchel, T.M. \& B.B. Jorgensen. 1977. Detritus food chains of aquatic ecosystems: The role of bacteria. Adv. Microb. Eco1. 1: 1-58.

Ferguson, R.I. \& P. Rublee. 1976. Contribution of bacteria to standing crop of coastal plankton. Limnol. Oceanogr. 21: 141-145.

Fletcher, M. 1979. A microautoradlographic study of the activity of attached and free-living bacteria. Arch. Microbiol. 122: 271-274.

Goulder, R. 1977. Attached and free bacteria in an estuary w1th abundant 
suspended solids. J. App1. Bacteriol. 43: 399-405.

Gude, H. 1979. Grazing by protozoa as selection factor for activated sludge bacteria. Microb. Eco1. 5: 225-237.

Haas, L.W. \& K.L. Webb. 1979. Nutritional mode of several non-pigmented microflagellates from the York River Estuary, Virginia. J. exp. mar. Biol. Ecol. 39: 125-134.

Hanson, R.B. \& W.J. Wiebe. 1977. Heterotrophic activity associated with particle size fractions in a Spartina alterniflora salt-marsh estuary, Sapelo Island, Georgia, USA, and the Continental Shelf Waters, Mar. Biol. 42: $321-330$.

Harvey, R.W. \& L.Y. Young. 1980. Enumeration of partfcle-bound and unattached respiring bacteria in the salt marsh environment. Appl. Environ. Microbiol. 40: 156-160.

Hibberd, D.J. 1979. Notes on the ultrastructure of the genus Paraphysomonas Chrysophyceae) with special reference to $\underline{P}$. bandaiensis Takahashi. Arch. Protistenk. 121: 146-154.

Hobbie, J.E., R.J. Daley, \& S. Jaspar. 1977. Use of Nuclepore filters for counting bacteria by fluorescence microscopy. App1. Environ. Microbiol. 33: $1225-1228$.

Hobbie, J.E., O. Holm-Hansen, T.T. Packard, L.R. Pomeroy, R.W. Sheldon, J.P. Thomas \& W.J. Wiebe. 1972. A study of the distribution and activity of microorganisms in ocean water. Limnol. Oceanogr. 17: 544.

Jannasch, H.W. 1973. Bacterlal content of particulate matter in offshore surface waters. Limnol. Oceanogr. 18: 340-342.

Jannasch, H.W. \& P.H. Pritchard. 1972. The role of inert particulate matter in the activity of aquatic microorganisms. Mem. Ist. Ital. Idrobiol. $29(\mathrm{~S}): \quad 289-308$.

Jones, G.E. \& H.W. Jannasch. 1959. Aggregates of bacteria in sea water as 
determined by treatment with surface active agents. Limnol. Oceanogr. 4: 269-276.

Jordan, M.J. \& G.E. Likens. 1980. Measurement of planktonic bacterial production in an oligotrophic lake. Limnol. Oceanogr. 25: 719-732.

Kirchman, D. \& R. Mitchel1. 1982. Contribution of particle-bound bacterla to total microheterotrophic activity in five ponds and two marshes. App1. Environ. Microbiol. 43: 200-209.

Kjelleberg, S., B.A. Humphrey \& K.C. Marsha11. 1982. Effect of interfaces on small, starved marine bacterla. Appl. Environ. Microbiol. 43: 1166-1172. Linley, E.A.S. \& J.G. Field. 1982. The nature and ecological significance of bacterlal aggregation in a nearshore upwelling ecosystem. Est. Coastal Shelf Sc1. 14: 1-11.

Paer1, H.W. 1975. Microbial attachment to particles in marine and freshwater ecosystems. Microb. Ecol. 2: 73-83.

Paerl, H.W. \& S.M. Merke1. 1982. Differential phosphorus assimilation in attached vs. unattached microorganisms. Arch. Hydrobiol. 93: 125-134. Pedros-Alio, C. \& T.D. Brock. 1983. The importance of attachment to particles for planktonic bacteria. Arch. Hydrobiol. 98: 354-379. Pomeroy, L.R. 1983. Origin and distribution of flocculent aggregates. EOS, Trans. Amer. Geophys. Union 64: 1020 (Abstr.).

Pomeroy, L.R. \& R.E. Johannes. 1968. Occurrence and respiration of ultraplankton in the upper 500 meters of the ocean. Deep-Sea Res. 15: $381-391$.

Riemann, B. 1978. Differentiation between heterotrophic and photosynthetic plankton by size fractionation, glucose uptake, ATP, and chlorophylI content. Olkos 31: 358-367.

Robertson, M.L., A.L. Mills \& J.C. Zleman. 1982. Microblal synthesis of detritus-1ike particulates from dissolved organic carbon released by 
tropical seagrasses. Mar. Ecol. Prog. Ser. 7: 279-285.

Schleyer, M.H. 1981. Microorganisms and detritus in the water column of a subtidal reef of Natal. Mar. Eco1. Prog. Ser. 4: 307-320.

Seki, H. 1970. Microbial blomass on particluate organic matter in seawater of the euphotic zone. Appl. Microbiol. 19: 960-962.

Seki, H. 1971. Microbial clumps in seawater in the euphotic zone of Saanich Inlet (British Columbia). Mar. Biol. 9: 4-8.

Sherr, B.F., E.B. Sherr \& T. Berman. 1983. Grazing, growth and ammonium excretion rates of a heterotrophic microflagellate fed with four species of bacteria. Appl. Environ. Microbiol. 45: 1196-1201.

Sieburth, J.McN. 1976. Bacterial substrates and productivity in marine ecosystems. Ann. Rev. Ecol. Syst. 7: 259-285.

Sleburth, J.McN. \& P.G. Davis. 1982. The role of heterotrophic nanoplankton in the grazing and nurturing of planktonic bacteria in the Sargasso and Caribbean Sea. Ann. Inst. oceanogr., Paris 58(S): 285-295.

Sorokin, J.I. 1971. On the role of bacteria in the productivity of tropical oceantc waters. Int. Revue ges. Hydrobiol. 56: 1-48.

Stevenson, L.H. 1978. A case for bacterlal dormancy in aquatic systems. M1crob. Ecol. 4: 127-133.

Taga, N. \& O. Matsuda. 1974. Bacterlal populatlons attached to plankton and detritus in seawater. In: Colwe1l, R.R. \& R.Y. Morita (eds.), Effect of the ocean environment on microbial activities. University Park, 433-448.

Telkova, L.A. 1964. New data on food selzling in the Genus Rhynchomonas (Flagellatae). Zoo1. Zhur.43: 606-607.

Wangersky, P.J. 1977. The role of particulate matter in the productivity of surface waters. Helgo1. wiss. Meeresunt. 30: 546-564.

Watson, S.W., T.J. Novitsky, H.L. Quinby \& F.W. Valo1s. 1977. Determination of bacterial number and blomass in the marine environment. Appl. Environ. 
Microbio1. 33: 940-946.

Wiebe, W.J. \& L.R. Pomeroy. 1972. Microorganisms and their association with aggregates and detritus in the sea: A microscopic study. Mem. Ist. Ital. Idrobiol. 29(S): 325-352.

Wiebe, W.J. \& D.F. Smith. 1977. Direct measurement of dissolved organic carbon release by phytoplankton and incorporation by microheterotrophs. Mar. B1ol. 42: 213-223.

W1lliams, P.J.1eB. 1970. Heterotrophic utilization of dissolved organic compounds in the sea. 1. Size distribution of population and relationship between respiration and incorporation of growth substrates. J. Mar. B1ol. Assoc. U.K. 50: 859-870.

Wilson, C.A. \& L.H. Stevenson. 1980. The dynamics of the bacterial population associated with a salt marsh. J. exp. mar. B1ol. Ecol. 48: 123-138.

Zimmermann, R. 1978. Estimation of bacterial number and biomass by eplfluorescence microscopy and scanning electron microscopy. In: Rheinheimer, G. (ed.), Microbial ecology of a brackish water environment. Springer-Verlag, New York, p. 103-120.

Zobell, C.E. 1943. The effect of solid surfaces upon bacterial activity. J. Bacteriol. $46: 39-56$. 
CHAPTER 5

SELECTIVE GRAZING AND SURVIVAL TIMES

OF ACARTIA TONSA ON PHYTOPLANKTON AND HETEROTROPHIC MICROFLAGELLIATES 
ABSTRACT

The acceptability of heterotrophic microflagellates as a food source for the calanold copepod Acartia tonsa was tested in survival and selective grazing experiments. Survivorship of $A$. tonsa offered two species of microflagellates was comparable to survivorship of copepods offered two species of algae and was greater than survivorship of starved Controls or copepods offered bacterla. Filtration rates of copepods offered heterotrophic microflagellates and algae in mixtures of similar density or biomass were generally comparable. Both mechanistic and behavioral selectivity were suggested by the feeding activities of the copepods. It is concluded that heterotrophic microflagellates may represent an important trophic link between bacterloplankton and this calanold copepod. Microflagellates may const1tute a significant fraction of the food of this copepod in areas where nanoplankton dominate the plankton community or where phytoplankton are rare (e.g. below the photic zone), but the absolute contribution of these protozoa to the diet of $\underline{A}$. tonsa is dependent upon the relative abundance of microflagellates to other autotrophic and heterotrophic microorganisms. 


\section{INTRODUCTION}

Bacterivorous protozoa have traditionally been credited with two roles in plankton communities. First, they prevent the buildup of bacterial biomass and stimulate bacterial degradation of non-1lving organic material thus ensuring the remineralization of nutrients vital for primary productivity. Second, they convert bacterial biomass into animal biomass making it avallable to filter-feeding zooplankton and thereby providing a mechanism for the recovery of energy from the detrital food chaln to the conventional phytoplankton-copepod-fish food chain. While the role of protozoa in nutrient regeneration has received considerable attention in recent years (see reviews by Stout, 1980; Taylor, 1982; Goldman, in press), their 1mportance as a 11nk between the detrital food chain and the conventional plankton food chain has not been adequately addressed.

Interest in the protozoa as remineralizers has been nurtured by early reports which suggested that protozoa grazing on bacteria increased the decomposition rates of detritus and resulted in elevated rates of nutrient regeneration (Johannes, 1964; 1965). However, high cell ylelds (conversion of food biomass into consumer blomass) have also been observed for bacteria and protozoa. Cell yields of 50-95\% have been observed for bacteria growing on natural substrates (summarlzed by Williams, 1981), and ce11 yields of 37-78\% for cillates (sumarized by Curds \& Bazin, 1977) and 20-68\% for microflagellates (Chapter 3; Kopylov et al., 1980; Fenchel, 1982b; Sherr et a1., 1983) have been observed for protozoa growing on bacterla. These results suggest that a significant fraction of the energy contained in detrital material is not directly reduced to dissolved nutrients and carbon dioxide, but is converted to protozoan biomass. This protozoan blomass is then avallable to zooplankton capable of capturing these microorganisms.

The necessity of protozoa as a trophic link between bacteria and 
herbivorous or omnivorous copepods has been obscured by the potential for the direct utilization of bacterial blomass by zooplankton, and the meager information presently available on this topic (see Poulet, 1983, for review). Ingestion of bacterioplankton has been demonstrated for a larvacean (Hollibaugh et al., 1980; King et al., 1980) and a freshwater cladoceran (Peterson et al., 1978) which possess the capabilities for removing very small particles from suspension. In addition, the ingestion of aggregated bacteria has been suggested as a mechanism whereby copepods may graze directly on bacterial populations in the plankton (Sek1 \& Kennedy, 1969; Sorok1n, 1971; Rieper, 1978). Despite this evidence for ingestion of bacteria by zooplankton, it seems unlikely that bacteria contribute significantly to the diet of most copepods. Unattached/unaggregated bacteria are generally smaller than the particle sizes retained by most copepods. Furthermore, ingestion of bacteria by zooplankton does not necessarily indicate the ability of zooplankton to obtaln nutrition from the ingested biomass. For example, the "protozoan 1ink" has been suggested as an essential factor for the utilization of chroococcold cyanobacterial biomass by calanold copepods (Johnson et al., 1982) due to the apparent inability of these zooplankton to digest cyanobacterla (Silver \& Alldredge, 1981; Johnson et a1., 1982). Similarly, Seki (1964) obtalned poor growth of the brine shrimp Artemia on a diet of bacteria, but obtained excellent growth when a heterotrophic dinoflagellate (Oxyrrhis) was added. Addition of another protozoan (Uronchia) allowed cultivation of Artemia to the adult stage (Seki, 1966). These observations suggest that a protozoan intermedlate may be necessary for the utilization of bacterial biomass by at least some zooplankton.

Several investigators have now concluded that bacterivorous protozoa form a potentially important trophic link between bacterla and herbivorous or omnivorous copepods (Berk et al., 1977; Porter et al., 1979; Conover, 1982; 
Azam et al., 1983). This conclusion is based on a number of studies which have documented the ingestion of protozoa by copepods (Sek1, 1964, 1966; Hamilton \& Preslan, 1969; Zillıoux, 1969; Pavlovskaja \& Pechen, 1971; Berk et al., 1976, 1977; Helnle et al., 1977; Porter et al., 1979; KleinBreteler, 1980; Kopylov et al., 1981; Rleper \& Flotow, 1981; Robertson, 1983). Most of these studies have examined the removal of clliates or large $(>20 \mathrm{um})$ flagellates from suspension. However, recent work has indicated that heterotrophic microflagellates may be the primary grazers of bacterioplankton (Chapter 3; Davis, 1982; Fenche1, 1982b; Sieburth \& Davis, 1982). Heterotrophic microflagellates constitute a significant fraction of the blomass of nanoplankton populations (Chapter 1; Fenche1, 1982d; Davis et al., submitted) and greatly exceed the density of bacterivorous clliates in oceanic plankton communities (Chapters $1 \& 2$ ). It is therefore probable that the Importance of these microorganisms as a food source for herbivorous or omnivorous copepods has been underestimated.

While heterotrophic microflagellates may represent a significant fraction of the biomass of plankton communities, the ability of copepods to prey on these protozoa cannot be easily predicted. Species of Acartia are capable of retaining particles as smal1 as 1-2 $\mu \mathrm{m}$ (Hargrave \& Geen, 1969; Roman, 1978), but particles smaller than 10-1.5 $\mu \mathrm{m}$ are apparently retained with decreased efficiency (Hargrave \& Geen, 1969; Nival \& Nival, 1976). Since most microflagellates are less than $12 \mu \mathrm{m}$ in size (Davis \& Sieburth, 1982), they may be retained with an efficiency which is less than $100 \%$. Decreasing filtering efficlency with decreasing particle size can presumably be explained by viewing food capture as a result of the mechanical action of a fixed feeding structure. However, behavior also affects the selection of food particles by copepods. Changes in the effective intersetule spacings of the feeding appendages has been suggested for Acartla clausi (Donaghay \& Small, 
1979). Post-capture rejection of food particles has been suggested for several species of copepods (Poulet \& Marsot, 1978; Donaghay \& Sma11, 1979; Fernandez, 1979), and microcinetamographic work has confirmed this behavior (J.D. Strickler, pers. comm.; Paffenhofer \& VanSant, 1983). For these reasons empirical verification of the ability of filter-feeding copepods to ingest heterotrophic microflagellates is required in order to determine the potential importance of these protozoa as a trophic link between bacterioplankton and copepods.

Behavioral responses to food particles can result in feeding preferences which cannot be explained solely by a mechanistic view of food capture. Kopylov et a1. (1981) investigated the ingestion of heterotrophic microflagellates by the calanoid copepod A. clausi. The authors observed that this copepod did not feed on two species of heterotrophic microflagellates when the microflagellates occurred as solitary cells but fed readily on detrital particles with attached microflagellates. The authors concluded that A. claus1 was incapable of seizing solitary microflagellates. These results suggest that A. clausi may have avoided the protozoa since the flagellates were within the size range of particles retained by $\underline{A} \cdot \underline{\text { clausi }}$ (Nival \& Nival, 1976). This behavior could have important implications for the recovery of energy from the detrital food chain via bacterivorous microflagellates and requires further investigation.

The ability of the copepod Acartia tonsa to graze heterotrophic microflagellate populations and to survive on a diet consisting solely of microflagellates was tested in this study. Survival times of adult $\underline{\text { A. }} \underline{\text { tonsa }}$ offered a diet of microflagellates were comparable to survival times for copepods offered unialgal diets. In comparison, survival times of copepods offered bacteria were similar to survival times for starved Controls, suggesting the importance of a "protozoan link" between bacteria and the 
copepods. Grazing and ingestion rates of copepods offered mixtures of heterotrophic microflagellates and algae were comparable for food organisms of similar size and abundance. The results suggest a potential importance of microflagellates in the diet of $\underline{A}$. tonsa. 
METHODS AND MATERIALS

Copepods were collected from surface waters of Great Harbor, Woods Hole, Massachusetts, USA on 9 November 1983 (surv1val experiment) and 18 December 1983 (selective grazing experiment) using a 333 um mesh plankton net. Adult female Acartia tonsa were pipetted into filtered seawater $(0.22 \mu \mathrm{m}$ pore size) and kept at $13.0^{\circ} \mathrm{C}$ (approximately amblent) for $24 \mathrm{hr}$ before use in either experiment. This treatment was performed to avoid the potential effects of previous diet on the feeding behavior of the copepods (Donaghay \& Sma11, 1979). Survival Experiment

A survival experiment was carried out in 50x100 mm Pyrex crystallizing dishes at $15.5^{\circ} \mathrm{C}$ in dim continuous 1ight. Five types of food plus a starved control were tested. The phytoplankton Dunaliella tertlolecta and Isochrysis galbana, the heterotrophic microflagellates Monas sp. (clone \#2/80-2) and Cryptobla marls, and the bacterlum Pseudomonas halodurans were used as food. Dunaliella and Isochrysis are roughly ellipsoldal cells with longest dimensions of $12 \mu \mathrm{m}$ (Dunaliella) and $5 \mu \mathrm{m}$ (Isochrysis) and volumes of 157 $\mu^{3}$ and $47.7 \mu^{3}$, respectively. Cryptobla is teardrop-shaped with average dimensions of $4 \times 6 \mu \mathrm{m}$ and a volume of $41.9 \mu^{3}$. Monas is a spherical cell with an average diameter of $4 \mu \mathrm{m}$ and a corresponding volume of $33.5 \mu \mathrm{m}^{3}$. The volume of Pseudomonas was calculated to be $0.73 \mu^{3}$ based on cell dimensions. The phytoplankton were grown in Gulllard's f/2 medium (Guillard, 1975) made with Great Harbor (Woods Hole, Massachusetts) seawater and harvested during exponential growth. Heterotrophic microflagellates were grown on a mixed bacterial flora which was enriched by adding $0.01 \%$ yeast extract to natural seawater. Microflagellates were also harvested for the experiment during exponential growth. The bacterial culture was grown on $0.01 \%$ yeast extract and was harvested $24 \mathrm{hr}$ after inoculation (1ate exponential growth). Bacteria were offered as food to serve as a control for 
bacterla present in the microflagellate cultures. The densities of the food organisms in the stock cultures were determined by epifluorescence microscopy using the acridine orange technique (Watson et a1., 1977; Davis \& Sieburth, 1982) and were then diluted with Millipore-f1ltered seawater $(0.22 \mu \mathrm{m}$ pore size) if necessary. Food organisms were offered to the copepods in excess. Their concentrations were adjusted such that all foods were offered at a similar biomass per unit volume. Initlal densities and biovolumes of prey are given in Table 5.1.

Adult Acartia were placed five per dish in $150 \mathrm{ml}$ of seawater in each of six dishes for a total of 30 individuals per treatment. Starved Controls were placed in $0.22 \mathrm{\mu m}$ pore size Millipore-filtered seawater. The dishes were examined daily for the number of survivors, and all survivors were then transfered to dishes replenished with food organisms or freshly filtered seawater.

\section{Selective Grazing Experiment}

A selective grazing experiment was carried out to test the ability of $A$. tonsa to preferentially graze microflagellates and algae. The same algae and microflagellates used in the survival experiment were used in this experiment. Two-member mixtures of the four food organisms were offered to 15 A. tonsa individuals held in $200 \mathrm{ml}$ of seawater in $250 \mathrm{ml}$ polycarbonate flasks. All permutations of the four food organlsms were tested (Monas vs. Dunaliella, Monas vs. Isochrys1s, Cryptobla vs. Dunalie1la, Cryptobia vs. Isochrysis, Monas vs. Cryptobla, and Dunaliella vs. Isochrysis). Mixtures of food organisms were prepared by diluting cultured algae or microflagellates with filtered natural seawater. Two flasks were prepared for each mixture of food organisms. In one flask the number of food organlsms was adjusted such that the density of both food species were nearly equal (in actuality, initial densities differed by as much as $2.6 \mathrm{x}$ (Tables 5.3-5.5). In the other flask 
Table 5.1. Initial densities and biovolumes of the food organisms employed in the Acartia tonsa survival experiment.

$\frac{\begin{array}{c}\text { Food } \\ \text { Organism }\end{array}}{\text { Monas sp. }}$ Cryptobia maris

Dunallella tertiolecta

Isochrysis galbana

Pseudomonas halodurans

$\begin{gathered}\text { Density } \\ \left(\text { No. } \mathrm{ml}^{-1}\right)\end{gathered}$
$1.0 \times 10^{5}$
$6.6 \times 10^{4}$
$2.1 \times 10^{4}$
$5.1 \times 10^{4}$
$4.6 \times 10^{6}$

Biovolume

(um3 $\mathrm{ml}^{-1}$ )

3. $3 \times 10^{6}$

$2.8 \times 10^{6}$

$3.3 \times 10^{6}$

$2.4 \times 10^{6}$

$3.4 \times 10^{6}$ 
the number of food organisms was adjusted such that the biovolumes per unit volume of seawater were nearly equal (In actuality initial blovolumes also differed by as much as $5.5 \mathrm{x}$ ). Control flasks, flasks containing food organisms but no copepods, were also prepared and sampled to monitor any change in the density of the food specles which was not a result of copepod grazing.

The flasks were sampled immediately after the copepods were added to them and after $24 \mathrm{hr}$. All flasks were malntained at amblent water temperature $\left(11.0^{\circ} \mathrm{C}\right)$ in $\mathrm{d}$ im 1 ight. The flasks were continuously rotated $360^{\circ}$ in a vertical plane at $2 \mathrm{rpm}$ which malntained thorough mixing of the contents and prevented preferentlal sett1ing of the food organisms. Samples were preserved with filtered glutaraldehyde at a final concentration of $1.0 \%$. Food organisms were counted by epifluorescence microscopy (Caron, 1983), using cell size, shape and chlorophyll fluorescence to distinguish the different food species.

Filtration rates and Ingestion rates of $\mathrm{A}$. tonsa were calculated from the change in the density of food organisms between 0 and $24 \mathrm{hr}$ according to the equations of Frost (1972). These rates were corrected for changes in the prey density in the Control flasks. All rates were normalized to a rate copepod $^{-1}$ day $^{-1}$. In flasks where copepods had died during the experiment, the number of copepods alive at the conclusion of the experiment was used to calculate rates per individual. 
RESULTS AND DISCUSSION

Results of the survival experiment conducted with Acartia tonsa are given in Table 5.2 and Figure 5.1. Copepods fed bacteria only had survival times which were comparable to copepods maintained in flltered seawater. Mean survival times were 3.7 and 4.0 days for starved Controls and bacteria-fed copepods, respectively. In contrast, mean survival times were 5.7 and 6.9 days for copepods fed algae and 5.8 and 6.8 days for copepods fed heterotrophic microflagellates.

Contingency table analysis (Sokal \& Rohlf, 1969) was performed on the survivorship data at day 3,6 and 9. Survivorship of copepods fed the bacterlum Pseudomonas halodurans was never significantly different than that of the starved Controls. At day 3 only the copepods fed Cryptobia showed survivorship which was significantly greater $(P<0.05)$ than that for starved Controls. At day 6, copepods fed Dunalie1la or Cryptobia had survivorship which was significantly greater $(P<0.05)$ than starved Controls, and at day 9 al1 4 groups fed algae or microflagellates showed survivorship which was greater $(P<0.01)$ than for starved Controls or copepods fed bacteria. Survivorship among the copepods fed algae or microflagellates was never significantly different $(P<0.05)$.

While significant differences were apparent between copepods fed microflagellates or algae and the starved Controls, survival times were in general relatively short. The short survival times observed for $A$. tonsa in this experiment may have resulted from several factors. Daily transfer of the copepods may have caused physical damage to the copepods. Also, the small size of the prey organisms may have resulted in filtering efficlencies less than $100 \%$. Low filtering efficiency may in turn have provided the copepods with a small amount of food for the energy expended. The unispectes nature of the food may also have shortened the survival times. Multispecies assemblages 
Table 5.2. Mean survival time ( +1 standard deviation), median survival times, and maximum Individual survival times for Acartia tonsa fed different diets.

\begin{tabular}{|c|c|c|c|}
\hline Treatment & $\begin{array}{c}\text { Mean } \\
\text { Survival } \\
\text { Time } \\
\text { (days) } \\
\end{array}$ & $\begin{array}{c}\text { Median } \\
\text { Survival } \\
\text { Time } \\
\text { (days) } \\
\end{array}$ & $\begin{array}{c}\text { Maximum } \\
\text { Survival } \\
\text { Time } \\
\text { (days) } \\
\end{array}$ \\
\hline $\begin{array}{l}\text { Filtered } \\
\text { Seawater }\end{array}$ & $\begin{array}{r}3.7 \\
+2.4\end{array}$ & 3.7 & 8 \\
\hline $\begin{array}{l}\text { Pseudomonas } \\
\text { halodurans }\end{array}$ & $\begin{array}{r}4.0 \\
+2.5\end{array}$ & 4.3 & 8 \\
\hline$\frac{\text { Monas }}{\text { sp. }}$ & $\begin{array}{r}5.9 \\
+3.0\end{array}$ & 6.7 & 12 \\
\hline$\frac{\text { Cryptobia }}{\text { maris }}$ & $\begin{array}{r}6.8 \\
+2.8\end{array}$ & 7.5 & 12 \\
\hline$\frac{\text { Dunaliella }}{\text { tertlolecta }}$ & $\begin{array}{r}6.9 \\
+4.7\end{array}$ & 8.0 & 17 \\
\hline$\frac{\text { Isochrysis }}{\text { galbana }}$ & $\begin{array}{r}5.7 \\
+3.5\end{array}$ & 5.6 & 14 \\
\hline
\end{tabular}


Figure 5.1. Survival of Acartia tonsa individuals fed different diets. (๑) Copepods maintained in filtered seawater. (3) Copepods fed Pseudomonas halodurans. ( $\Delta$ ) Copepods fed Monas sp.. ( $)$ Copepods fed Cryptobia maris. (\$) Copepods fed Dunaliella tertiolecta. ( $\nabla$ ) Copepods fed Isochrysis ga1bana. 


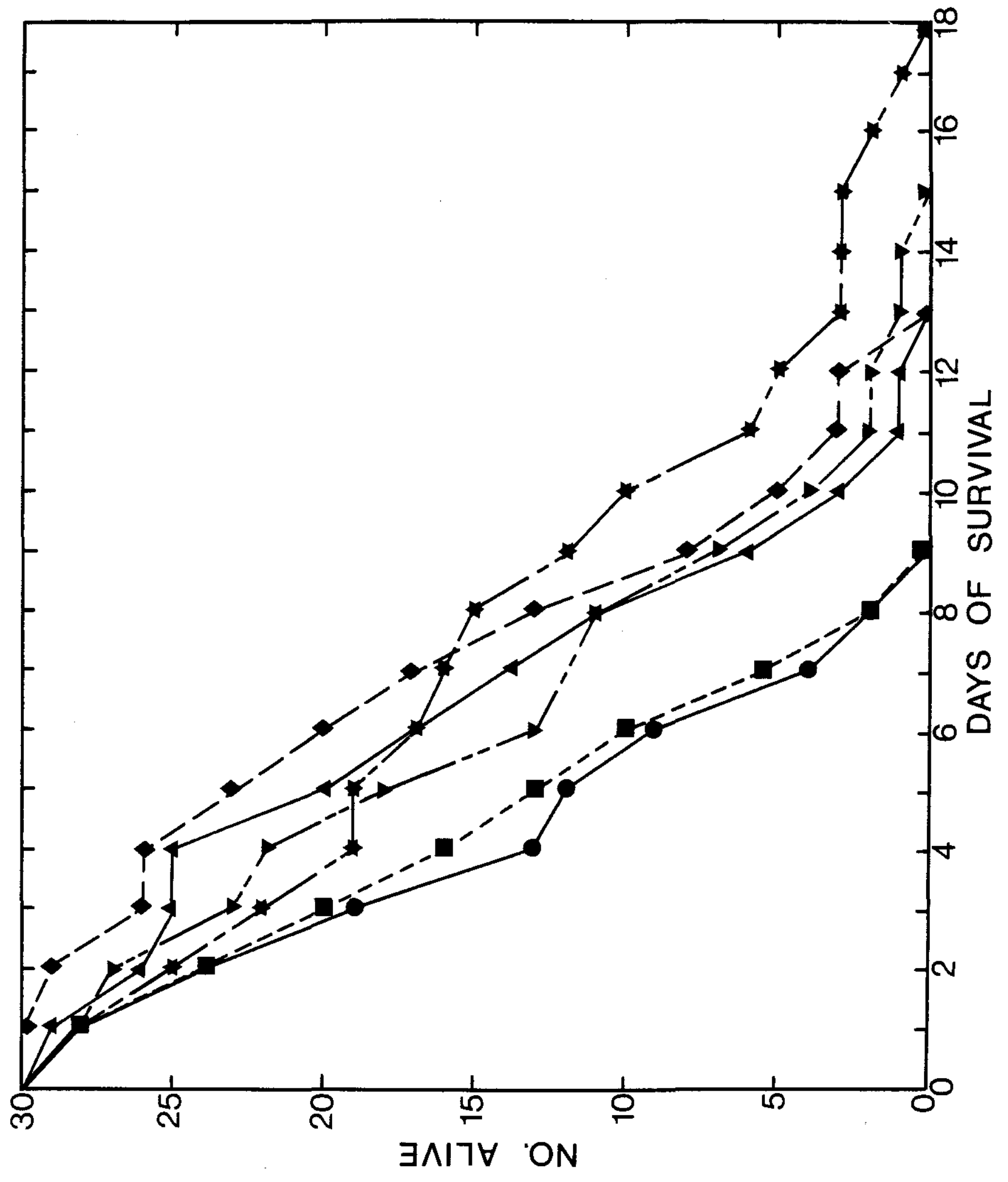


have been shown to support better growth of copepods than unispecies assemblages (Nassogne, 1970; Cahoon, 1981). Temperature may have also affected survival times of $\underline{A}$. tonsa. The sampling period occurred near the time of the seasonal succession from A. tonsa to A. clausi in Buzzards Bay (Anraku, 1964). Survival of A. tonsa may have been adversely affected by the water temperatures of the survival experiment $\left(15.5^{\circ} \mathrm{C}\right)$. It is possible that the combined effects of some or all of these factors reduced survival times of the copepods. These factors may have also minimized the differences between survival times of fed and starved copepods.

The results of the selective grazing experiment are given in Tables 5.3-5.5. In general, both heterotrophic microflagellates were grazed by A. tonsa at filtration rates which were comparable to rates observed for the copepods feeding on algae. Filtration rates observed for the food species

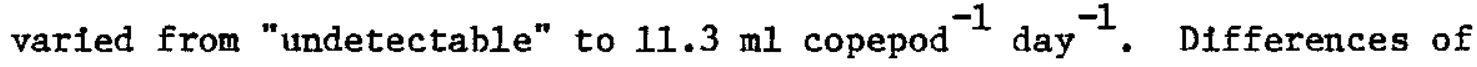
less than $10 \%$ between the density of food organisms at the beginning and end of a feeding perlod were within the microscopical counting error and filtration rates were not calculated for these instances (indicated by "NS" in Tables 5.3-5.5). Therefore, filtration rates which were $<0.9 \mathrm{ml}^{\text {copepod }}{ }^{-1}$ day $^{-1}$ were not detected.

Filtration rates for both prey species in the mixture were similar in only two trials out of a total of 12 trials. In the remalning 10 trials filtration rates calculated for the two prey species in each mixture differed despite the fact that density or biomass per unit volume were often similar for the two prey species. These differences in filtration rates appear to be a result of both mechanistic and behavioral responses by the copepod to the prey.

Filtration rates and ingestion rates of A. tonsa for Monas sp. are given In Tables 5.3 and 5.5 when offered in combination with Dunaliella, Isochrysis and Cryptobia. When Monas was offered to $\underline{A}$. tonsa the same density as 
Table 5.3. Results of a selective grazing experiment with Acartia tonsa. Copepods were offered 2-member mixtures of prey organisms. Filtration rates and ingestion rates were calculated according to the equations of Frost (1972) based on the removal of food organisms as shown by epifluorescence microscopy.

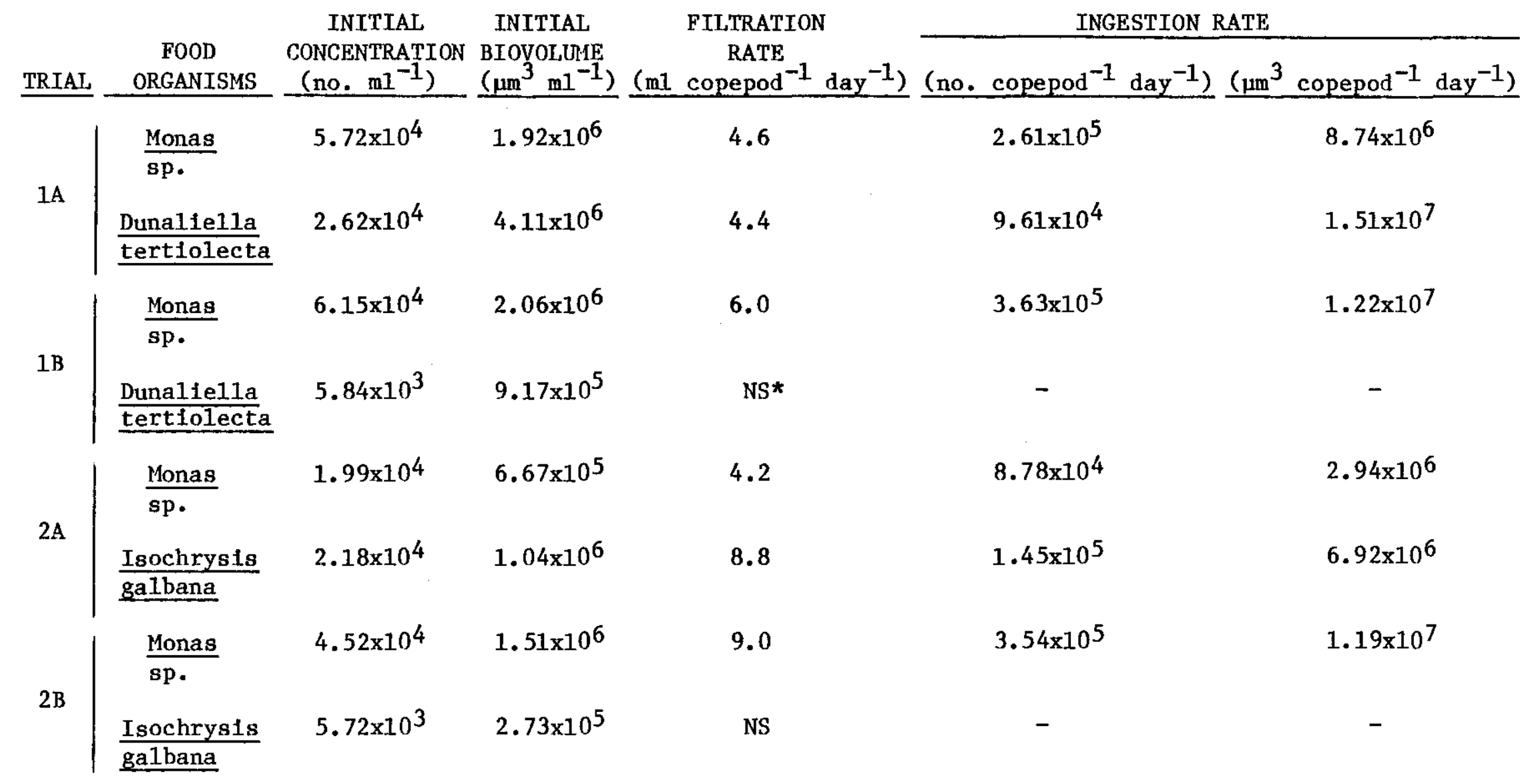

*NS in Tables 5.3-5.5 indicates that the epifluorescence counts of the prey organisms after $24 \mathrm{hr}$ differed from the initial counts by less than $10 \%$ (within the counting error). Filtration and ingestion were not calculated. 
Table 5.4. Results of a selective grazing experiment with Acartia tonsa. Copepods were offered 2-member mixtures of prey organisms. Filtration rates and ingestion rates were calculated according to the equations of Frost (1972) based on the removal of food organisms as shown by epifluorescence microscopy.

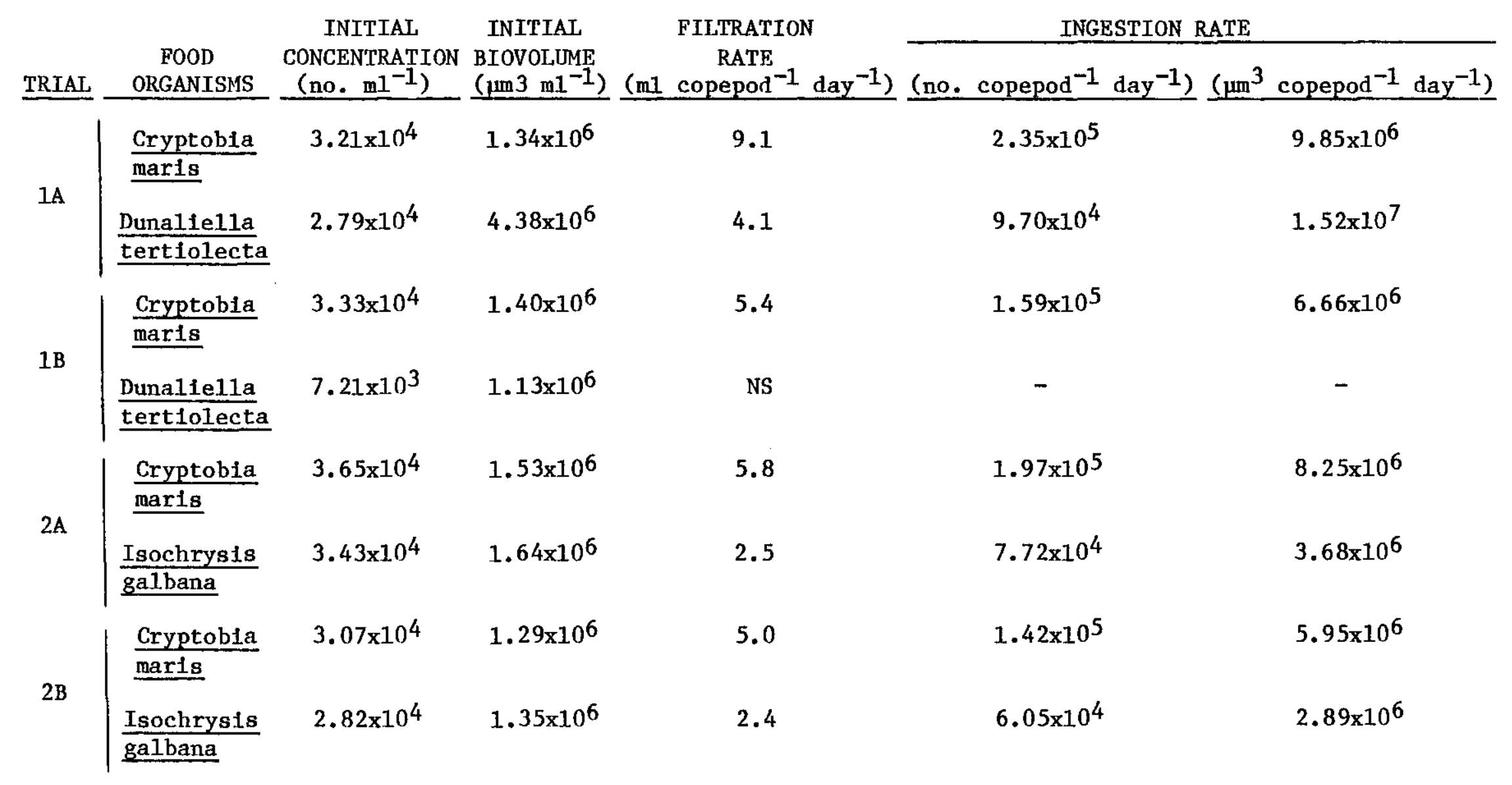


Table 5.5. Results of a selective grazing experiment with Acartia tonsa. Copepods were offered

2-member mixtures of prey organisms. Filtration rates and ingestion rates were calculated according to

the equations of Frost (1972) based on the removal of food organtsms as show by eptfluorescence microscopy.

\begin{tabular}{|c|c|c|c|c|c|c|}
\hline \multirow[b]{2}{*}{ TR.IAL } & \multirow[b]{2}{*}{$\begin{array}{c}\text { FOOD } \\
\text { ORGANISMS } \\
\end{array}$} & \multirow{2}{*}{$\begin{array}{c}\text { INITIAL } \\
\text { CONCENTRATION } \\
\left(\text { no. } \mathrm{ml}^{-1} \text { ) }\right. \\
\end{array}$} & \multirow{2}{*}{$\begin{array}{l}\text { INITIAL } \\
\text { BIOVOLUME } \\
\left(\mu \mathrm{m}^{3} \mathrm{ml}^{-1}\right) \\
\end{array}$} & \multirow{2}{*}{ 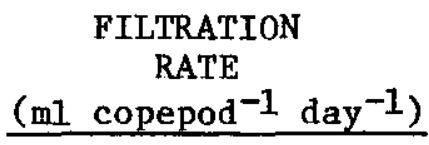 } & \multicolumn{2}{|c|}{ INGESTION RATE } \\
\hline & & & & & (no. copepod ${ }^{-1}$ day $^{-1}$ ) & $\left(\mathrm{um}^{3}\right.$ copepod $\left.^{-1} \mathrm{day}^{-1}\right)$ \\
\hline \multirow{2}{*}{$1 \mathrm{~A}$} & $\frac{\text { Monas }}{\text { sp. }}$ & $6.99 \times 10^{4}$ & $2.34 \times 10^{6}$ & 1.8 & $1.41 \times 10^{5}$ & $4.72 \times 10^{6}$ \\
\hline & $\frac{\text { Cryptobia }}{\text { maris }}$ & $2.70 \times 10^{4}$ & $1.13 \times 10^{6}$ & 11.3 & $2.36 \times 10^{5}$ & $9.89 \times 10^{6}$ \\
\hline \multirow{2}{*}{$1 \mathrm{~B}$} & $\frac{\text { Monas }}{\text { sp. }}$ & $6.19 \times 10^{4}$ & $2.07 \times 10^{6}$ & 9.9 & $7.26 \times 10^{5}$ & $2.43 \times 10^{7}$ \\
\hline & $\frac{\text { Cryptobia }}{\underline{\text { mar1s }}}$ & $1.37 \times 10^{4}$ & $5.74 \times 10^{5}$ & 9.2 & $1.03 \times 10^{5}$ & $4.32 \times 10^{6}$ \\
\hline \multirow{2}{*}{$2 \mathrm{~A}$} & $\frac{\text { Dunaliella }}{\text { tertiolecta }}$ & $2.79 \times 10^{4}$ & $4.38 \times 10^{6}$ & 4.5 & $1.06 \times 10^{5}$ & $1.66 \times 10^{7}$ \\
\hline & $\frac{\text { Isochrysis }}{\text { galbana }}$ & $3.10 \times 10^{4}$ & $1.48 \times 10^{6}$ & NS & - & - \\
\hline \multirow{2}{*}{ 2B } & $\frac{\text { Dunaliella }}{\text { tertiolecta }}$ & $9.92 \times 10^{3}$ & $1.56 \times 10^{6}$ & 4.3 & $3.55 \times 10^{4}$ & $5.57 \times 10^{6}$ \\
\hline & $\begin{array}{l}\text { Isochrysis } \\
\text { galbana }\end{array}$ & $2.60 \times 10^{4}$ & $1.24 \times 10^{6}$ & NS & - & - \\
\hline
\end{tabular}


Dunaliella (Table 5.3, Trial 1A), the filtration rates for Dunaliella and Monas were simflar. Because of the greater size of Dunaliella, the ingestion rate ( $\mu^{3}$ copepod $^{-1}$ day $^{-1}$ ) observed for Dunaliella in this trial exceeded that for Monas. However, when the two species were offered at a similar biomass $\mathrm{ml}^{-1}$ the filtration rate for Dunaliella was undetectable. When Monas and Isochrygis were offered to $\underline{A}$. tonsa (Table 5.3, Trial 2A \& 2B), the filtration rate and 1ngestion rate for Isochrysis was approximately $2 x$ the rate for Monas when the two specles were offered at similar densities. When the Initial density of Isochrysis was approximately one order of magnitude less than that of Monas, the filtration rate for Isochrysis was undetectable. When Monas and Cryptobia were offered to $\underline{A}$. tonsa (Table 5.5, Trials IA \& 1B), Cyptobla was filtered at rates comparable to or greater than rates for Monas, even though Monas was present in higher densities and biomass.

These results indicate that Monas was a dominant portion of the ingested biomass of $\underline{A}$. tonsa only when it was present in much greater densities than the other spectes. Monas is the smallest of the four species tested in this study (volume $=33.5 \mathrm{\mu m}^{3}$ ), and is presumably at the lower 1imit of the filtering capabilities of this species and related Acartia species (Gauld, 1966; Nival \& Niva1, 1976). Utilization of this blomass appears to be maximized only when larger food particles are in low abundance. In all trials the biomass of Monas ingested by the copepods increased when the density of the other prey species in the mixture was reduced.

Filtration rates and ingestion rates of $\underline{A}$. tonsa for Cryptobia are given in Tables 5.4 and 5.5 when offered to the copepods in the presence of the other prey species. Filtration rates of $\underline{A}$. tonsa for Cryptobla were greater than or equal to filtration rates observed for all other prey species in all trials. When Cryptobia was offered to the copepods in the presence of $\underline{\text { Dunaliella }}$ and Isochrysis at similar densities (Table 5.4, Trials 1A \& 2A), 
filtration rates observed for Cryptobia were approximately $2 \mathrm{x}$ the rates for the algae. When Monas and Cryptobia were offered at a density ratio of 2.6:1 (Table 5.5, Trial 1A) filtration rates observed for Cryptobia were $6 x$ greater than rates for Monas. InItial blomass $\mathrm{ml}^{-1}$ was greater for the algae and Monas than for Cryptobla in these trials.

These results suggest a behavioral selection by $\underline{A}$. tonsa of Cryptobia in the presence of Dunaliella. Filtration rates were greater for Cryptobla than for Dunaliella offered at similar densities, even though Dunaliella is the larger cell. A similar situation was apparent for Cryptobia and Isochrysis. Filtration rates for Cryptobia were much higher than for Monas, but a mechanistic explanation is possible in this case since Monas is smaller than Cryptobia. Ingestion rates $\left(\mu^{3}\right.$ copepod $^{-1}$ day $\left.^{-1}\right)$ in these trials were twice as great for Cryptobla as for Isochrysis and Monas, but comparable rates were observed for Cryptobia and Dunallella because of the larger cell size of Duna1ie1la.

When Dunaliella and Cryptobia or Isochrysis and Cryptobla were offered to A. tonsa at similar biomass $\mathrm{ml}^{-1}$ (Table 5.4, Trials $1 B \& 2 B$ ), filtration rates for Dunaliella were undetectable but were unchanged for Isochrysis. When Monas and Cryptobla were offered at a density ratio of 4.5:1 (Table 5.5, Trial 1B), filtration rates were similar for both prey, and the biomass of Monas Ingested by the copepods exceeded that of Cryptobla.

Filtration rates and ingestion rates of $\underline{A}$. tonsa when the two algae were offered to the copepods (Table 5.5, Trials 2A \& 2B) indicate that Dunallella was selected over Isochrysis when the two were offered at similar concentrations or at similar biomass $\mathrm{ml}^{-1}$. Filtration rates were undetectable for Isochrysis in both trials. This selection may be a result of a behavioral response to the prey, or reduced filtration efficiency for Isochrysis which is smaller. Since filtration rates for Isochrysis were 
detectable in the other trials it is concluded that a behavioral response by A. tonsa was involved.

The results of the selective grazing experiment suggest a preference of $\mathrm{A}$. tonsa for Cryptobia relative to Monas for the two microflagellate specles tested, and for Dunallella relative to Isochrysis for the two algal species tested. Coincidentally, mean survival times (Table 5.2) for copepods fed Cryptobia and Dunallella were longer than survival times for Monas and Isochrysis, although the differences in survival were not significant by contingency table analysis. Nonetheless, the results suggest that nutritional value of the prey may differ and that these differences may manifest themselves in selective grazing and survival times.

Kopylov et a1. (1981) noted that Acartia clausi was Incapable of seizing two species of heterotrophic microflagellates when they occurred in suspension. However, the copepods in that study readily fed on particles with attached microflagellates. The authors concluded that microflagellates were acceptable as food for A. clausi but were too small to be efficiently filtered. The microflagellates used by Kopylov et al. (1981) were at least 5.4 and $6.8 \mu \mathrm{m}$ in diameter (assuming spherical cells). These sizes are within the range of particle sizes which A. clausf can capture (Nival \& Nival, 1976) and are larger than the sizes of the microflagellates used in this study. The densities of microflagellates used in this study were comparable to the densities employed by Kopylov et al. (1981). Therefore, the Inability of A. clausi to feed on the two microflagellate species employed in that study may Indicate selective behavior of the copepods rather than a physical inability to seize the prey. Behavioral selectivity has been noted for $\underline{A}$. clausi and for other copepods (Poulet \& Marsot, 1978; Donaghay \& Sma11, 1979; Fernandez, 1979). Whether the explanation is mechanical or behavioral, the results of Kopylov et al. (1981) suggest that suspended microflagellates were unavailable 
to A. clausi.

Unlike the results of Kopylov et al. (1981) with A. clausi, this study has shown that $\underline{A}$. tonsa readily removes heterotrophic microflagellates from suspension. There is no indication from the results that the ingestion of microflagellates by the copepods was avolded. There is also no evidence that the presence of heterotrophic microflagellates resulted in depressed filtration rates or ingestion rates by the copepods. Chemical stimuli can affect the feeding behavior of copepods (Cowles, 1983), and feeding of copepods on non-living particles can be induced in the presence of acceptable food (Frost, 1977) or a chemical stimulus (J.D. Strickler, pers. comm.). Filtration and ingestion rates of $\mathrm{A}$. tonsa in the absence of heterotrophic microflagellates (Table 5.5, Trials 2A\&2B) were comparable to rates in their presence. In fact, filtration rates for individual prey species were highest In the trials which contained only protozoa (Table 5.5, Trials $1 \mathrm{~A} \& 1 \mathrm{~B}$ ). These results confirm the acceptability of protozoa as food for this planktonic copepod.

The inability of $\underline{\text { A. }}$ claus1 to capture suspended microflagellates (Kopylov et al., 1981) is difflcult to rationalize with the results from this study on A. tonsa. If A. clausi is incapable of efficiently capturing nanoplankton-sized particles in the plankton, then the ability of A. tonsa to utilize this food resource may account, in part, for the dominance of the latter species in Buzzards Bay during the summer when nanoplankton dominate the phytoplankton (Anraku, 1964; Roman, 1978). However, if A. clausi is avolding the suspended protozoa, then more work is required to determine which species of protozoa are acceptable food organlsms to planktonic copepods.

It is difficult to draw conclusions on the importance of heterotrophic microflagellates in the diet of Acartia tonsa based on the present study. The densities of microflagellates used in this study $\left(9.09 \times 10^{3}-8.60 \times 10^{4}\right.$ 
cells $\mathrm{ml}^{-1}$ ) are higher than concentrations generally observed in the ocean (Chapter 1; Davis \& Sleburth, 1982; Fenche1, 1982d; Davis et al., submitted) although such densities have been observed in eutrophic environments (Sorokin, 1981). In addition, given that $\underline{\mathrm{A}}$. clausi apparently does not accept some microflagellates as food (Kopylov et al., 1981), it is not possible at present to estimate what portion of the in-situ protozoan population is acceptable prey to A. tonsa. Finally, the presence of large phytoplankton cells, or animal prey may affect the filtration rates of A. tonsa for these small protozoa. Under conditions where larger prey are available, heterotrophic microflagellates may constitute a minor portion of the diet of $\underline{A}$. tonsa.

Nonethless, the present study has established that microflagellates are acceptable food for $\underline{A}$. tonsa, and apparently have a nutritional value comparable to the algae tested in this study (as evidenced by simflar survival times). In addition, when these protozoa occur in densities comparable to photosynthetic microorganisms of similar size they are removed from the water with equal efficiencies.

Heterotrophic microflagellates generally constitute approximately $1 / 2$ of the nanoplankton population within the euphotic zone of the ocean (Chapter 1; Davis et al., submitted). In turn, nanoplankton dominate the blomass of a number of oceanic environments (Brocke1, 1981; Beers et al., 1982; Booth et a1., 1982). The results of this study suggest that under these conditions heterotrophic microflagellates may constitute a significant fraction of the diet of filter-feeding copepods. In addition, microflagellates may constitute an important source of nutrition for zooplankton during the heterotrophic phase of plankton succession (Sorkin, 1977) and in the deep ocean (Harding, 1974). More work is required to quantify the role of heterotrophic microflagellates as intermediates for the utllization of bacterlal biomass by filter-feeding zooplankton. 


\section{REFERENCES}

Anraku, M. 1964. Influence of the Cape Cod Canal on the hydrology and on the copepods in Buzzards Bay and Cape Cod Bay, Massachusetts. Limno1. Oceanogr. 9: 46-60.

Azam, F., T. Fenchel, J.G. Field, J.S. Gray, L.A. Meyer-Re1l \& F. Thingstad. 1983. The ecological role of water-column microbes in the sea. Mar. Ecol. Prog. Ser. 10: 257-263.

Beers, J.R., F.M.H. Reld \& G.L. Stewart. 1982. Seasonal abundance of the microplankton population in the North Pacific central gyre. Deep-Sea Res. 29: 227-245.

Berk, S.G., D.C. Brownlee, D.R. Heinle, H.J. Kling \& R.R. Colwell. 1977. Cllates as a food source for marine planktonic copepods. Microb. Ecol. 4: $27-40$.

Berk, S.G., R.R. Colwell, E.B. Small. 1976. A study of feeding responses to bacterial prey by estuarine ciliates. Trans. Amer. Micros. Soc. 95: 514-520.

Booth, B.C., J. Lewin \& R.E. Norris. 1982. Nanoplankton specles predominant In the subarctic Pacific in May and June 1978. Deep-Sea Res. 29: 185-200. Brokel, K. von. 1981. The importance of nanoplankton within the pelagic Antarctic ecosystem. Kieler Meeresforsch. 5: 61-67.

Cahoon, L.B. 1981. Reproductive response of Acartia tonsa to variations in food ration and quality. Deep-Sea Res. 28: 1215-1221.

Caron, D.A. 1983. Technique for enumeration of heterotrophic and phototrophic nanoplankton, using epifluorescence microscopy, and comparison with other procedures. Appl. Environ. Microblol. 46: 491-498.

Conover, R.J. 1982. Interrelations between microzooplankton and other plankton organisms. Ann. Inst. oceanogr., Paris. 58(S): 31-45. Cowles, 1983. T.J. Food perception by marine copepods: Behavioral responses 
to chemical and mechanlcal stimuli. EOS, Trans. Amer. Geophys. Unfon 64 : 1036 (Abstr.).

Curds, C.R. \& M.J. Bazin. 1977. Protozoan predation in batch and continuous culture. Adv. Aquatic Microbiol. 1: 115-176.

Davis, P.G. 1982. Bacterivorous flagellates in marine waters. Ph.D. Thesis, University of Rhode Island. 218pp.

Davis, P.G., D.A. Caron, P.W. Johnson \& J.McN. Sleburth. Submitted. Geographic, seasonal and diel distribution of phototrophic and heterotrophtc components of the picoplankton and nanoplankton in the North Atlantic. Mar. Ecol. Prog. Ser.

Davis, P.G. \& J.McN. Sieburth. 1982. Differentiation of the photosynthetic and heterotrophic populations of nanoplankters by epifluorescence microscopy. Annales Inst. oceanogr., Paris. 58(S): 249-259.

Donaghay, P.L. \& L.F. Sma11. 1979. Food selection capabilitles of the estuarine copepod Acartia clausi. Mar. Biol. 52: 137-146.

Fenche1, T. 1982b. Ecology of heterotrophic microflagellates. II. Bioenergetics and growth. Mar. Ecol. Prog. Ser. 8: 225-231. Fenchel, T. 1982d. Ecology of heterotrophic microflagellates. IV. Quantitative occurrence and importance as bacterlal consumers. Mar. Ecol. Prog. Ser. 9: 35-42.

Fernandez, F. 1979. Particle selection in the nauplius of Calanus pacificus. J. Plankton Res. 1: 313-328.

Frost, B. 1972. Effects of size and concentration of food particles on the feeding behavior of the marine planktonic copepod Calanus pacificus. Limno1. Oceangr. 17: 805-815.

Frost, B. 1977. Feeding behavior of Calanus pacificus in mixtures of food particles. Limnol. Oceanogr. 22: 472-491.

Gauld, D.T. 1966. The swimming and feeding of planktonic copepods. In: 
Barnes, H. (ed.). Some contemporary studies on marine science. George Allen \& Unwin Ltd., London, p. 313-334.

Goldman,J.C. In press. Oceanic nutrient cycles. In: Fasham, M.J. (ed.). Flows of energy and materials in marine ecosystems. Plenum Press, New York.

Guillard, R.R.L. 1975. Culture of phytoplankton for feeding marine invertebrates. In: Smith, W.L. \& M.H. Chanley (eds.). Culture of marine 1nvertebrate animals. P1enum Press, New York, p.29-60.

Hamilton, R.D. \&. J.E. Preslan. 1969. Cultural characteristics of a pelagic marine Hymenostome clilate, Uronema sp. J. exp. mar. Biol. Ecol. 4: 90-99.

Harding, G.C.H. 1974. The food of deep-sea copepods. J. mar. biol. Ass. U.K. $54: 141-155$.

Hargrave, B.T. \& G.H. Geen. 1969. Effects of copepod grazing on two natural phytoplankton populations. J. Fish. Res. Bd. Can. 27: 1395-1403. Heinle, D.R., R.P. Harris, J.F. Ustach, \& D.A. Flemer. 1977. Detritus as food for estuarine copepods. Mar. Biol. 40: 341-353.

Hollibaugh, J.T., J.A. Fuhrman \& F. Azam. 1980. Radioactively labeling of natural assemblages of bacterioplankton for use in trophic studies. Limno1. Oceanogr. 25: 172-181.

Johannes, R.E. 1964. Phosphorus excretion and body size in marine animals: Microzooplankton and nutrient regeneration. Science 146: 923-924. Johannes, R.E. 1965. Influence of marine protozoa on nutrient regeneration. Limno1. Oceanogr. 10: 434-442.

Johnson, P.W., H. Xu\& J.McN. Sieburth. 1982. The utilization of chroococcoid cyanobacterla by marine protozooplankters but not by calanoid copepods. Ann. Inst. oceanogr., Paris. 58(S): 297-308.

King, K.R., J.T. Holllbaugh \& F. Azam. 1980. Predator-prey interactions 
between a larvacean 01kopleura diolca, and bacterloplankton in enclosed water columns. Mar. Biol. 56: 49-57.

KlelnBreteler, W.C.M. 1980. Continuous breeding of marine pelagic copepods in the presence of heterotrophic dinoflagellates. Mar. Ecol. Prog. Ser. 2: 229-233.

Kopylov, A.I., T.I. Mamayeva \& S.F. Batsanin. 1980. Energy balance of the colorless flagellate Parabodo attenuatus (Zoomastigophora, Protozoa). Oceanol. 20: 705-708.

Kopylov, A.I., A.F. Pasternak \& Y.V. Molseyev. 1981. Consumption of zooflagellates by planktonic organisms. Oceanol. 21: 269-271.

Nival, P. \& S. Nival. 1976. Particle retention efficlencies of an herbivorous copepod, Acartia clausi (adult and copepodite stages): Effects on grazing. Limnol. Oceanogr. 21: 24-38.

Nassogne, A. 1970. Influence of food organisms on the development and culture of pelagic copepods. Helgolander wiss. Meeresunters. 20: 333-345. Paffenhofer, G.-A. \& K.B. VanSant. 1983. Feeding of the marine planktonic copepod Eucalanus peleatus on living and non-living material. EOS, Trans. Amer. Geophys. Union 64: 1035 (Abstr.).

Pavlovskaja, T.Y. \& G.A. Pechen. 1971. Infusoria as a food for some mass species of marine planktonic animals. Zool. Zhur. 50: 633-640.

Peterson, B.J., J.E. Hobble \& J.F. Haney. 1978. Daphnia grazing on natural bacteria. Limnol. Oceanogr. 23: 1039-1044.

Porter, K.G., M.L. Pace \& J.F. Battey. 1979. Clliate protozoans as links in freshwater planktonic food chains. Nature 277: 563-565.

Poulet, S.A. 1983. Factors controlling utilization of non-algal diets by particle-grazing copepods. A review. Oceanol. Acta 6: 221-234.

Poulet, S.A. \& P. Marsot. 1978. Chemosensory grazing by marine calanoid copepods (Arthropoda: Crustacea). Science 200: 1403-1405. 
Rieper, M. 1978. Bacterla as food for marlne harpacticoid copepods. Mar. B1ol. 45: 337-345.

Rieper, M. \& C. Flotow. 1981. Feeding experiments with bacterla, cillates and harpacticold copepods. Kieler Meeresforsch. 5: 370-375.

Robertson, J.R. 1983. Predation by estuarine zooplankton on tintinnid cillates. Est. Coast. Shelf Sci. 16:27-36.

Roman, M.R. 1978. Tidal resuspension in Buzzards Bay, Massachusetts. II. Seasonal changes in the size distribution of chlorophyll, particle concentration, carbon and nitrogen in resuspended particulate matter. Est. Coastal Mar. Scl. 6: 47-53.

Sek1, H. 1964. Studies on microbial participation to food cycle in the sea. I. Particlpation in the microcosm at static condition. J. Oceanogr. Soc. Japan 20: 20-32.

Sek1, H. 1966. Studies on microblal participation to food cycle in the sea. III. Trial cultivation of brine shrimp to adult in a chemostat. J. Oceanogr. Soc. Japan 22: 27-32.

Sek1, H. \& O.D. Kennedy. 1969. Marine bacterla and other heterotrophs as food for zooplankton in the Strait of Georgla during the winter. J. Fish. Res. Bd. Canada 26: 3165-3173.

Sherr, B.F., E.B. Sherr \& T. Berman. 1983. Grazing, growth and ammonium excretion rates of a heterotrophic microflagellate fed with four species of bacteria. Appl. Environ. Microbiol. 45: 1196-1201.

Sleburth, J.McN. \& P.G. Davis. 1982. The role of heterotrophic nanoplankton in the grazing and nurturing of planktonic bacterla in the Sargasso and Caribbean Sea. Ann. Inst. oceanogr., Paris 58(S): 285-295. Silver, M.W. \& A.L. Alldredge. 1981. Bathypelagic marine snow: Deeprsea algal and detrital community. J. Mar. Res. 39: 501-530. Sokal, R.R. \& R.J. Rohlf. 1969. Blometry. W.H. Freeman, San Francisco, 
776pp.

Sorokin, J.I. 1971. On the role of bacteria in the productivity of tropical oceanic waters. Int. Revue ges Hydrobiol. 56: 1-48.

Sorokfn, Y.I. 1977. The heterotrophic phase of plankton succession in the Japan Sea. Mar. B1ol. 41: 107-117.

Sorokin, Y.I. 1981. Microheterotrophic organisms in marine ecosystems. In: Longhurst, A.R. (ed.). Analysis of marine ecosystems. Academic Press, London, p.293-342.

Stout, J.D. 1980. The role of protozoa in nutrient cycling and energy flow. Adv. M1croblol. Eco1. 4: 1-50.

Taylor, G.T. 1982. the role of pelagic heterotrophic protozoa in nutrient cycling: A revlew. Ann. Inst. oceanogr., Parls 58(S): 227-241. Watson, S.W., T.J. Novitsky, H.L. Quinby \& F.W. Valois. 1977. Determination of bacterlal number and blomass in the marlne environment. App1. Environ. Microbiol. 33: 940-946.

Williams, P.J.1eB. 1981. Incorporation of microheterotrophic processes into the classical paradigm of the planktonic food web. Kleler Meeresforsch. 5: $1-28$.

Z11lioux, E.J. 1969. A continuous recirculating culture systen for planktonic copepods. Mar. B1o1. 4: 215-218. 
APPENDIX I

FIXATION, SAMPLE PREPARATION, AND COUNTING PROCEDURES

FOR EPIFLUORESCENCE COUNTS 
Five populations of microorganisms were counted using epifluorescence microscopy; phototrophic and heterotrophic picoplankton $(0.2-2.0 \mu \mathrm{m})$, phototrophic and heterotrophic nanoplankton $(2.0-20 \mu \mathrm{m})$, and microalgae greater than $20 \mu \mathrm{m}$. These populations were visualized and differentlated using fluorochrome stains and the autofluorescence of photosynthetic plgments. The counting techniques and diagnostic features for their Identification are discussed below. More complete descriptions of these techniques can be found in the references provided. All counts were made using a Zelss standard microscope equipped with a $50 \mathrm{~W}$ high pressure mercury lamp.

\section{Sample Fixation:}

All samples were fixed with glutaraldehyde at a final concentration of 1\%. For seawater samples, a stock solution of $10 \%$ glutaraldehyde was prepared by diluting $50 \%$ (aqueous solution) Reagent grade glutaraldehyde in full strength natural seawater. The seawater helps prevent osmotic shock of the microorganlsms during fixation and also acts as a buffer. The solution was filtered through a $0.22 \mu \mathrm{m}$ pore size Millipore filter. For freshwater samples the glutaraldehyde was diluted to $10 \%$ with distilled water. Sodium cacodylate $(0.1$ M) was added to buffer the solution, and the $\mathrm{pH}$ was adjusted to 7.2 .

Samples were preserved by adding $20 \mathrm{ml}$ of the $10 \%$ glutaraldehyde solution to $180 \mathrm{ml}$ of sample. Samples were stored at $5^{\circ} \mathrm{C}$ in the dark to maintain the autofluorescence of the photosynthetic pigments. Heterotrophic Picoplankton (Hnano):

Heterotrophic picoplankton (primarily heterotrophic bacteria) were counted using two fluorochrome stains; acridine orange (AO; Francisco et a1., 1973; Watson et al., 1977) and 4'6-diamidino-2-phenylindole (DAPI; Porter \& Felg, 1980). DAPI was used primarily for counting field samples. It was superior to $\mathrm{AO}$ due to slower quenching (AO faded rapidly, especlally in very small 
$(0.2-0.4 \mu \mathrm{m})$ bacteria) and its higher speciflcity (detritus was not stained as readily as with A0 in macroaggregates samples). A0 requires a shorter staining time, however, and was used in most labortatory experiments using cultured bacterla (which are larger and more easily visualized).

An approprlate sample volume $(0.5-10 \mathrm{ml})$ was placed in a $25 \mathrm{~mm}$ Millipore fllter assembly for stalning. A pre-stained (Hobble et al., 1977) Nuclepore filter ( $0.2 \mu \mathrm{m}$ pore size) was used to collect the stained sample. A backing filter ( $0.45 \mathrm{~mm}$ pore size Millipore filter) was placed beneath the Nuclepore filter to promote even dispersion of the bacteria on the filter. Bacteria were stained in the filtration assembly with DAPI (final stain concentration of $1 \mathrm{ug} / \mathrm{ml}$ ) for 10 minutes or AO (final stain concentration of $0.01 \% \mathrm{~W}: \mathrm{V}$ ) for 3 minutes. The sample was drawn down onto the filter with a vacuum pressure of less than $10 \mathrm{~cm} \mathrm{Hg}$, rinsed with filtered distilled water, and then mounted (still wet) on a glass slide. One drop of immersion oll was placed on the filter, followed by a glass coverslip.

Hpico were counted using a 100X Neofluar ofl objective. A G365 exciter filter, an FT420 chromatic beam splitter, and an LP418 barrier filter were used for observing the DAPI-stained preparations, while a BP450-490 exciter filter, an FT420 chromatic beam splitter, and an IsP20 barrier f1lter were used for the A0-stained preparations. An ocular grid was used to facilitate counting, since the Neofluar lens does not produce a planar image. This curvature causes difficulties in observing bacteria at the edges of the field of view. The number of Hplco per grid was recorded for flelds of view from all parts of the filter. A total of at least 500 Hpico per filter was counted. The number of Hpico in the sample was then calculated using the following formula.

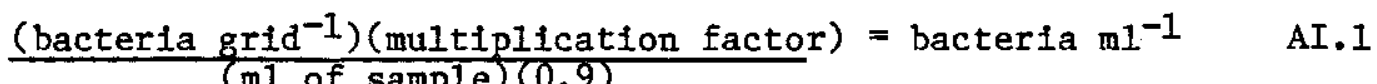
(m1 of sample)(0.9) 
The factor (0.9) takes into account the dilution of the sample by the fixative. The "multiplication factor" relates the area of the ocular grid to the area of the filter covered by sample.

$$
\text { Multiplication factor }=\frac{(\pi)\left(R^{2}\right)}{\left(S^{2}\right)}
$$

where $S$ is the length of the ocular grid, and $R$ is the radius of the filter funnel.

Phototrophic Picoplankton (Ppico):

Counts of Ppico were made on unstained preparations, using the auto-fluorescence of the photosynthetic pigments to visualize the cells. Chroococcold cyanobacterla always dominated this component of the plankton. Samples were drawn down onto pre-stalned Nuclepore filters ( $0.2 \mu \mathrm{m}$ pore size), as for bacterial counts, and mounted on glass slides with 1 drop of 1mmersion o11. However, a larger sample volume was needed due to the lower density of cyanobacterla $(5-50 \mathrm{~m} 1)$. The same set of filters used for the AO technique was used for the cyanobacterlal counts. Microorganisms which were $0.2-2.0 \mu m$ In size and fluoresced yellow-to-orange were enumerated as chroococcoid cyanobacteria. This color is due to the presence of phycoerythrin, a fairly diagnostic characteristic which can be used to distinguish these microorganisms from photosynthetic eucaryotes (which fluoresce red due to chlorophy11 a) and bacterla (which do not autofluoresce). This technique is not able to identify cyanobacteria which do not contain phycoerythrin, but is more managable than immunological techniques which may be capable of identifying them (Campbell et al., 1983). Red-fluorescing cells which were 0.2 to $2.0 \mu \mathrm{m}$ in size were also enumerated by this technique, but always constituted a small portion of the total Ppico.

The intense autofluorescence of the Ppico allowed a bit more freedom in counting than was possible for the bacterlal counts. Counts were performed 
using a 100X Neofluar objective lens, but usually the whole field of view was counted. Ppico per field of view was then converted to Ppico per ml using equation AI.1. The magnification factor used in equation AI.1 was changed to...

$$
\text { Multiplication factor }=\frac{(T \Gamma)\left(R_{1}^{2}\right)}{(T T)\left(R_{2}^{2}\right)}
$$

where $R_{1}$ is the radius of the filter funnel and $R_{2}$ is the radius of the field of view. When Pplco were very scarce, scans across the filter were made. All Ppico observed during each scan were recorded, and the length of the scan was measured using the mechanical stage divisions. Only one half of the fleld of view was counted at the beginning and end of the scan.

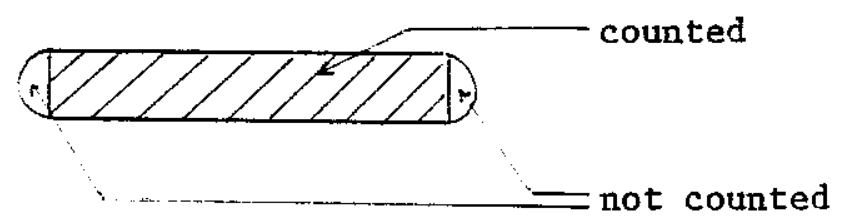

Counts were recorded as Ppico per scan, and were converted to Ppico per mI using equation Al. The multiplication factor for this counting procedure was...

$$
\text { Multiplication factor }=\frac{(T)\left(R^{2}\right)}{(L)(W)}
$$

where $R$ is the radius of the f1lter funnel, $L$ is the length of the scan and $W$ is the diameter of the fleld of view.

Phototrophic and Heterotrophic Nanoplankton:

The term "nanoplankton" refers to phototrophic and heterotrophic microorganisms which are 2.0-20 $\mu \mathrm{m}$ in size. It is largely an operational definition, but is composed largely of eucaryotes, primarily phototrophic and heterotrophic microflagellates. Several methods employing epifluorescence microscopy for counting these populations have been described (Davis \& Sleburth, 1982; Haas, 1982; Caron, 1983; Sherr \& Sherr, 1983). The advantages and disadvantages of these techniques have been reviewed by Caron (1983) 
(Appendix III). All of these techniques rely on fluorchrome stains to visula1ze the heterotrophs and on the autofluorescence of chlorophyl1-a to distinguish the phototrophs. However, the methods differ in their ability to distinguish fluorochrome and chlorophyl1-a fluorescence, and in the affinity of the stains for particulate materlal (see Appendix III for discussion). Samples prior to May 1982 were examined for Pnano and Hnano with the AO technique (Davis \& Sieburth, 1982). Two preparations are required for this technique. A stained sample is enumerated for total nanoplankton (heterotrophs and phototrophs), and an unstained sample is enumerated for phototrophs only. The number of heterotrophs is then determined by the difference between these two counts.

One other technique was used to count nanoplankton in samples collected prior to May 1982 where particulate materlal was particularly high. Binding of the stain to particulate materlal can obscure nanoplankton on these particles. These samples (unstained) were filtered down onto unstained Millipore filters $(0.22 \mu \mathrm{m}$ pore size) instead of pre-stained Nuclepore filters used with fuorochrome stains. The filters were then dried at $60^{\circ} \mathrm{C}$ for 15 minutes, and mounted on glass slides with 1 drop of 1 mmersion o11 above and below the filter. This procedure rendered non-phototrophic cells visible as greenish "ghosts", while phototrophic cells remained red-fluorescing. This technique was more time consuming since "ghosts" of the heterotrophs were not as obvious as fluorochrome-stained cells. However, this method ylelded results comparable to the AO technique for routine samples (Table AI.1), and was superior for samples containing large amounts of particulate material. This procedure was especially useful for the Lake Ontario samples which contained large amounts of detritus.

Samples collected after May 1982 were observed for nanoplankton with the primulin technique (Caron, 1983). This method was useful for all samples 
Table AI.1. Comparison of the acridine orange technique and the dried Millipore filter technique for counting phototrophic and heterotrophic nanoplankton. The sample was collected on $8 / 14 / 81$ at approximately $66 \mathrm{~m}$ in the North Atlantic $\left(25^{\circ} 49^{\prime} \mathrm{N}, 19^{\circ} 54^{\prime} \mathrm{W}\right)$. Counting error is \pm 1 standard deviation.

\begin{tabular}{|c|c|c|c|}
\hline $\begin{array}{l}\text { COUNTING } \\
\text { PROCEDURE }\end{array}$ & $\begin{array}{r}\text { PHOTOTROPHIC } \\
\text { NANOPLANKTON } \\
\left.\text { (NO. } \mathrm{ML}^{-1}\right) \\
\end{array}$ & $\begin{array}{l}\text { HETEROTROPHIC } \\
\text { NANOPLANKTON } \\
\left.\text { (NO. } \mathrm{ML}^{-1}\right) \\
\end{array}$ & $\begin{array}{c}\text { TOTAL } \\
\text { NANOPJANKTON } \\
\left(\text { NO. } \mathrm{ML}^{-1}\right) \\
\end{array}$ \\
\hline $\begin{array}{l}\text { acridine orange } \\
\text { stained }\end{array}$ & - & - & $\begin{array}{l}2.16 \times 10^{3} \\
\pm 0.25\end{array}$ \\
\hline unstained & $\begin{array}{l}5.64 \times 10^{2} \\
\pm 1.20\end{array}$ & - & - \\
\hline $\begin{array}{l}\text { A.0.-unstained } \\
\text { (heterotrophs) }\end{array}$ & - & $1.60 \times 10^{3}$ & - \\
\hline $\begin{array}{l}\text { dried Millipore } \\
\text { fllter }\end{array}$ & $\begin{array}{l}6.17 \times 10^{2} \\
+0.22\end{array}$ & $\begin{array}{l}1.43 \times 10^{3} \\
\pm 0.19\end{array}$ & $\begin{array}{l}2.05 \times 10^{3} \\
\pm 0.20\end{array}$ \\
\hline
\end{tabular}


(including macroaggregates) because of the use of separate excitation wavelengths for fluorochrome and chlorophyll-a fluorescence.

A11 nanoplankton counts were performed using a 100X Neofluar lens. Fields of view or scans across the filter were performed. Algae Greater Than 20 m:

Microalgae greater than $20 \mu \mathrm{m}$ were counted by performing scans on unstained samples (5-100 m1) drawn down onto pre-stained Nuclepore filters $(0.8 \mu \mathrm{m}$ pore size). The filter set used for the AO technique was used to observe red chlorophy11-a autofluorescence. Scans were performed with a $16 \mathrm{X}$ Neofluar lens. Where possible, algae were identified to major taxa (diatoms, dinoflagellates, etc.) and cell dimensions were recorded. 


\section{REFERENCES}

Campbel1, L., E.J. Carpenter \& V.J. Iacono. 1983. Identification and enumeration of marine chroococcoid cyanobacteria by 1mmunofluorescence. App1. Environ. Microbiol. 46: 553-559.

Caron, D.A. 1983. Technique for enumeration of heterotrophic and phototrophic nanoplankton using epifluorescence microscopy, and comparison with other procedures. App1. Environ. Microbiol. 46: 491-498.

Davis, P.G. \& J.McN. Sieburth. 1982. Differentiation of the photosynthetic and heterotrophic populations of nanoplankters by epifluorescence microscopy. Ann. Inst. Oceanogr. 58(S): 249-259.

Haas, L.W. 1982. Improved epifluorescent microscopic technique for observing planktonic micro-organisms. Ann. Inst. Oceangr. 58(S): 261-266.

Hobble, J.E., R.J. Daley \& S. Jaspar. 1977. Use of Nuclepore filters for counting bacterla by fluorescence microscopy. Appl. Environ. Microbiol. 33: $1225-1228$.

Francisco, D.E., Mah, R.A. \& A.C. Rabin. 1973. Acridine orange epifluorescence technique for counting bacteria in natural waters. Trans. Amer. Micros. Soc. 92: 416-421.

Porter, K.G. \& Y.S. Feig. 1980. The use of DAPI for identifying and counting aquatic microflora. Limnol. Oceanogr. 25: 943-948.

Sherr, B. \& E. Sherr. 1983. Enumeration of heterotrophic microprotozoa by epifluorescence microscopy. Est. Coast. Shelf Sci. 16: 1-7.

Watson, S.W., T.J. Novitsky, H.L. Quinby \& F.W. Valois. 1977. Determination of bacterial number and biomass in the marine environment. App1. Environ. Microbiol. 33: 940-946. 
APPENDIX II

USE OF CULTURAL AND EPIFLUORESCENCE TECHNIQUES

FOR THE ENUMERATION OF BACTERIVOROUS MICROFLAGELLATES 
Two techniques were employed to estimate the number of bacterivorous microflagellates in water and macroaggregate samples. The assumptions Inherent in these methods differ radically, and the density estimates obtained with these methods also differed markedly.

The eplfluorescence counting technique for counting heterotrophic nanoplankton has been previously described (Appendix I). Several factors complicate the use of Hnano counts as an estimate of the density of bacterivorous microflagellates. The epifluorescence technique does not determine the trophic mode of the nanoplankton (other than establishing that they are not photosynthetic). Therefore, herbivorous (and possibly osmotrophic) microflagellates would not be excluded from the counts. Also, the gametes or reproductive swarmers of other protozoa or metazoa may be Indistinguishable from bacterivorous microflagellates using the direct counting technique. Flagellated reproductive cells 2-20 $\mathrm{mm}$ in size are produced by a variety of planktonic and benthic organisms. In the open ocean, protozoa such as radiolarla and foraminifera can produce hundreds of thousands of reproductive cells per Individual (Be \& Anderson, 1976; Spindler et al., 1978; Anderson, 1983; Be et al., 1983). In neritic waters, reproductive swarmers produced by macroalgae, fungi, and molluscs (among others) may contribute to the population of "heterotrophic nanoplankton". Epifluorescence counts may also include dead or moribund microorganisms. These potential contributions to the Hnano population mean that the eplfluorescence counts represent an upper limit estimate of the number of bacterivorous microflagellates in a sample.

The Most Probable Number (MPN) culture technique used to estimate the density of bacterivorous microflagellates is based on the bacteriological technique used to estimate the number of viable bacteria suspended in a 1iquid. Serlal dilutions of an allquot of the sample are prepared and each of 
the dilutions are cultured (using an appropriate substrate). The number of bacteria in the undiluted sample can then be calculated using MPN Tables (Fisher \& Yates, 1963) by knowing the dilution factor, the number of cultures at each dilution level, and the total number of positive cultures. Singh (1946) adapted this method for estimating the number of protozoa in soil samples. It has subsequently been used for estimating protozoan density in seawater samples (Lighthart, 1969; Davis et al., 1978).

This technique assumes that the microflagellates are evenly distributed in the sample (i.e. not clumped or attached to particles), and that all viable microflagellates w11l grow in the cultures. The former assumption is clearly not valid for the macroaggregate samples. Attachment to, or close association with aggregates leads to underestimation of the population density, since clumped cells cannot be distributed evenly in the dilution series. Also, it is doubtful that all viable bacterivorous microflagellates are capable of growth in culture. Growth is presumably dependent upon the suitability of the bacterla used as food for the protozoa, the water quality of the cultures $\left(\mathrm{O}_{2}\right.$ concentration, sallnity fluctuations, trace metal contamination, etc.), or both. Food for the protozoa in the MPN cultures was provided by enriching the natural bacterlal flora present in the water samples. However, different media used to enrich the bacterla resulted in differences in the ability of the cultures to grow microflagellates. Several culture media tested for their ability to grow protozoa from seawater samples illustrate this point (Table AII.1). Growth of the bacterlal population must be rapid enough to provide food for the increasing density of protozoa in the cultures, but it cannot be so rapid that oxygen utilization by the bacteria is excessive. Purified chitin was apparently too poor an energy source for the bacteria flora, and did not support protozoan growth (no positive cultures observed). Yeast extract, on the other hand, supported very rapld growth of bacterla, but still 
Table AII.1. Most probable number estimates of bacterivorous microflagellates performed in the Sargasso Sea $\left(30^{\circ} 30^{\prime} \mathrm{N}, 75^{\circ} 55^{\prime} \mathrm{W}\right)$ using various substrates to enrich the natural bacterial flora. Sample depth was $1 \mathrm{~m}$.

\section{TREATMENT}

\begin{tabular}{|c|c|c|}
\hline BACTERIAI SUBSTRATE & $\begin{array}{c}\text { STERILIZATION } \\
\text { PROCEDURE } \\
\end{array}$ & $\begin{array}{l}\text { MOST PROBABLE NUMBER } \\
\left(\text { NO. ML } \mathrm{ML}^{-1} \times 100\right) \\
\end{array}$ \\
\hline Malt grain & Filtration * & 10.1 \\
\hline Purified chitin & Filtration & 0.31 \\
\hline Yeast extract $(0.01 \%)$ & Filtration & 1.73 \\
\hline Homogenized salp tissue & Filtration & 10.1 \\
\hline $\begin{array}{l}\text { Rice grain and } \\
\text { F/2 nutrients }\end{array}$ & Filtration & 10.1 \\
\hline $\begin{array}{l}\text { Rice grain and } \\
\text { bacterla }\end{array}$ & Filtration & 30.3 \\
\hline Rice grain & Autoclaved & 1.73 \\
\hline Rice grain & Filtration & 101. \\
\hline
\end{tabular}

*Natural seawater was filtered through a sterile $0.22 \mu \mathrm{m}$ pore size Millipore filter.

**From Guillard (1975).

*** Pseudomonas halodurans cultured in $0.01 \%$ yeast extract was added at a density of approximately $10^{8}$ bacteria $\mathrm{mi}^{-1}$. 
yielded poor protozoan growth, presumably due to excessive oxygen utilization. An alternative explanation for fewer positive cultures using yeast extract might be that rapid growth of the bacterla caused depletion of the bacterlal substrate. Subsequent grazing by protozoa would lead to a "boom and bust" situation for the protozoa. If cultures were not observed during the peak in protozoan abundance, no growth would be assumed.

These considerations suggest that a substrate that will be used relatively slowly, and will not be exhausted rapidly should provide the best possible method for enriching protozoan growth in the MPN cultures. Moderate but continuous bacterlal growth should allow a steady, constant increase in protozoan density, avolding a "boom and bust" situation, while also preventing excessive oxygen utilization due to uncontrolled bacterial growth. This reasoning presumably accounts for the higher MPN estimates for malt grains, rice gralns, and salp tissue (Table AII.1). Rice grains and filtered natural seawater (from the site of sample collection) ylelded the highest MPN estimate. Addition of the bacterium Pseudomonas halodurans (a suitable food source for species of microflagellates in culture), addition of $\mathrm{F} / 2$ nutrients for algal cultures (Guillard, 1975), or autoclaving the seawater all caused a reduction in the MPN relative to rice grains and filtered seawater. This reduction could be due to changes in the bacterial flora available as food ( $\underline{P}$. halodurans) or in the water quality (autoclaving). Based on this experiments, rice grains and filtered natural seawater were used as a culture medium in all MPN counts.

It can be concluded from the above discussion that the MPN technique represents a 1ower limit estimate of the number of bacterivorous microflagellates present in a sample. Therefore, the epifluorescence and the MPN techniques represent upper and lower limit estimates of the number of bacterivorous microflagellates in a sample. While these two techniques lack 
the accuracy which is desired in estimating population density, they are, at present, the best avallable means of estimating the density of these protozoa in field samples.

Figure AII.1 shows a lack of correlation between the estimates of microflagellate density as determined by the MPN and epifluorescence techniques for samples taken with Niskin bottles. The MPN estimates were generally less than $1 \%$ of the corresponding epifluorescence estimates and there was no obvious relationshlp between the results of the two methods. These results indicate that the two estimates are not simply "offset" by some factor.

A comparison of the two counting methods for macroaggregate samples (FIgure AII.2) shows that although there is still no $1: 1$ correspondence between the two methods, there is an indication that MPN and epifluorescence estimates may be correlated but offset by some constant. The dashed line in Figure AII.2 indicates the expected 1:1 correspondence between the two counts. The solid line is the regression for the data points (slope $=0.57$; r $=0.5)$.

Figures AII.I and AII.2 appear to indicate that when the absolute values of the MPN and ep1fluorescence techniques differed greatly there was little correlation between them. As the disparlty between the two counts decreased, a correlation approaching 1:1 appeared. This suggests that Niskin bottle samples either contain a significant number of microorganisms which are not bacterivorous microflagellates but are included in the epffluorescence counts, or that the microflagellates in the macroaggregate samples are easier to culture than microflagellates in the Niskin bottle samples.

The epifluorescence and MPN methods often yfeld such different numbers that an experiment was conducted to determine if they are capable of ylelding the same number, and what conditions might account for very large 
Figure AII.1. The density of bacterivorous microflagellates estimated by epifluorescence microscopy and the Most Probable Number culture technique in water samples collected with Niskin bottles. 


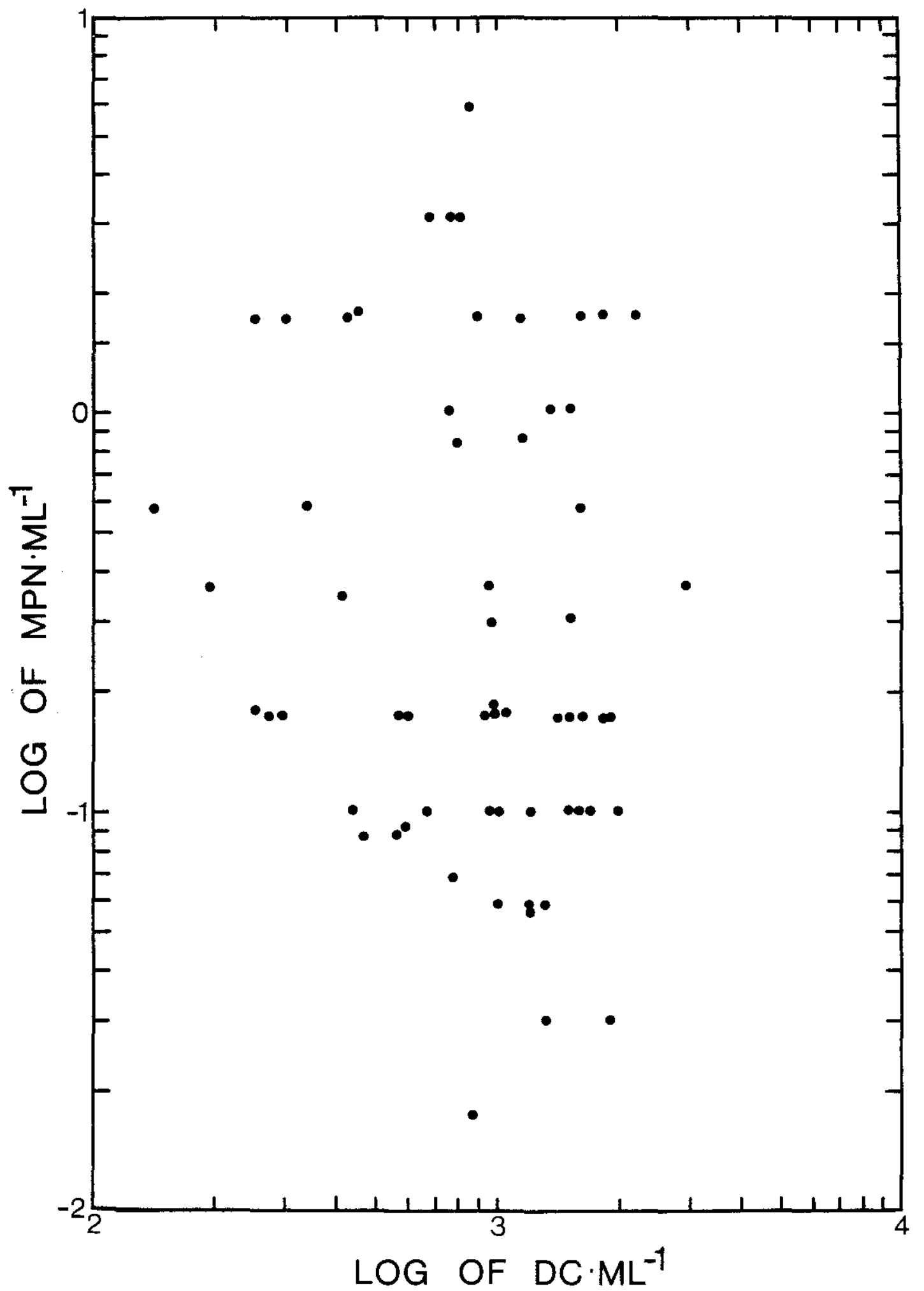


Figure AII.2. The density of bacterivorous microflagellates estimated by epifluorescence microscopy and by the Most Probable Number culture technique in macroscopic detrital aggregates. 


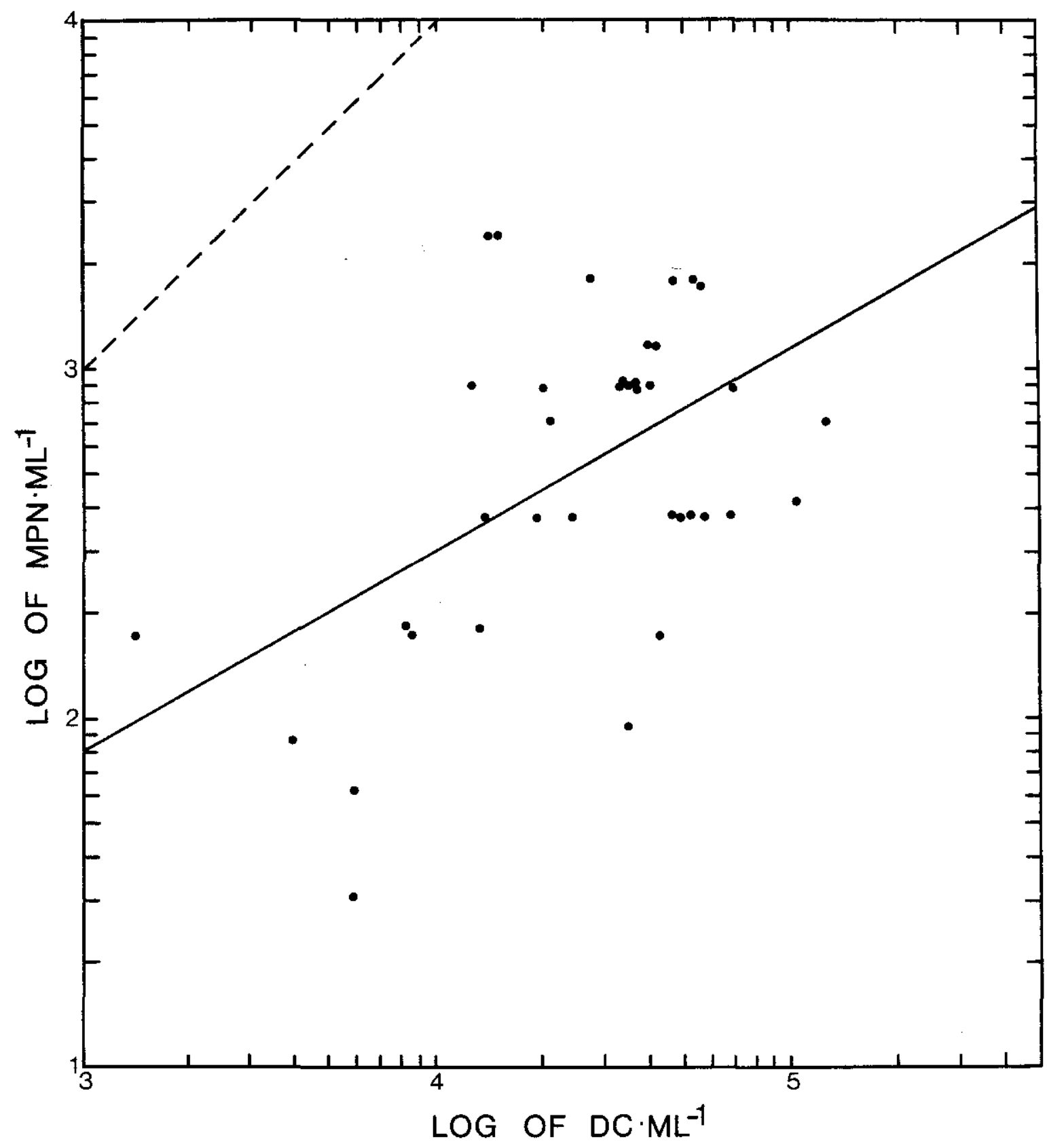


discrepancies in these estimates. An experiment was conducted to compare the MPN and epifluorescence counting techniques using 2 species of cultured microflagellates. The bacterium $\underline{P}$. halodurans was grown in 2 Fernbach flasks with $0.01 \%$ yeast extract for $48 \mathrm{hr}$. Antibiotics were then added to stop bacterial growth ( $60 \mathrm{mg} / 1$ of penicillin, $30 \mathrm{mg} / 1$ of streptomycin), and the flasks were inoculated with the microflagellate Monas sp. or Cryptobia maris. Microflagellate densities were monitored, and the cultures were sampled during exponential growth, at the time of exhaustion of the food supply, and several days after the exhaustion of the food supply. Preserved samples were counted using epifluorescence microscopy, and unpreserved samples were used in the MPN technique. The results are presented in Table AII.2. A comparison of the MPN and epifluorescence counts showed that the discrepancy between these 2 techniques was related to the growth phase. Closest agreement between the 2 methods was obtained when the microflagellates were in exponential growth. In this growth state, the MPN estimate was 53 and $29 \%$ of the epifluorescence count, indicating that the MPN and direct counting techniques are potentially capable of ylelding similar results. The MPN and direct counts were very different once the food supply had been exhausted, however, yielding estimates which were more than 3 and 4 orders of magnitude different. The MPN:DC ratio appears to be somewhat species-specific, since Monas and the bodonid flagellate did not yleld simflar ratios at similar growth stages. Samples taken at the time of exhaustion of the protozoan food yielded ratios of 0.61 and $14.3 \%$ for the Monas and bodonid, respectively. This difference may be due to differences in the resilience of starved (but viable) microflagellates, or to the differential degradability of dead microflagellates.

The range of MPN:DC ratios obtained in this experiment $(0.007-52.8 \%)$ is comparable to the range of MPN:DC ratios obtalned for seawater and macroaggregate samples (Table 2.6) and suggests that the nutritional status of 
Table AII.2. Estimates of the number of microflagellates in cultures as determined by the Most Probable Number (MPN) culture technique and direct counts by epifluorescence microscopy (DC).

\begin{tabular}{c}
$\begin{array}{c}\text { MICROFLAGELLATE } \\
\text { SPECIES }\end{array}$ \\
\hline Monas sp. \\
Monas sp. \\
Monas sp.
\end{tabular}

Cryptobia maris

Cryptobia maris

Cryptobia maris

GROWTH PHASE
Exponentia1
Early Stationary
Late Stationary
Exponentia1
Early Stationary
Late Stationary

EPIFLUORESCENCE

\begin{tabular}{c}
$\begin{array}{c}\text { COUNT } \\
\left(\text { no. } \mathrm{m}^{-1}\right)\end{array}$ \\
\hline $1.10 \times 10^{4}$ \\
$4.14 \times 10^{4}$ \\
$3.61 \times 10^{3}$ \\
$2.03 \times 10^{4}$ \\
$2.91 \times 10^{5}$ \\
$4.10 \times 10^{5}$
\end{tabular}

\begin{tabular}{|c|c|}
\hline $\begin{array}{c}\text { MPN } \\
\text { COUNT } \\
\left.\text { (no. } \mathrm{ml}^{-1}\right) \\
\end{array}$ & $\begin{array}{c}(\text { MPN } \times 100): D C \\
\text { RATIO }\end{array}$ \\
\hline $5.81 \times 10^{3}$ & 52.8 \\
\hline $2.52 \times 10^{2}$ & 0.61 \\
\hline $2.56 \times 10^{-1}$ & 0.007 \\
\hline $5.80 \times 10^{3}$ & 28.6 \\
\hline $4.15 \times 10^{4}$ & 14.3 \\
\hline $3.74 \times 10^{2}$ & 0.91 \\
\hline
\end{tabular}


the microflagellate population may account for a significant portion of the discrepancy between IPN and DC estimates. Alternatively, in light of the experiment just described, the magnitude of the discrepancy between the 2 counts may provide some information concerning the nutritional status of the population 1nvolved. Unfortunately, the contribution of the other potential Influences discussed previously makes it impossible to relate differences in the MPN and DC estimates of fleld samples solely to the growth phase of the microflagellates in the sample. 


\section{REFERENCES}

Anderson, 0.R. 1983. Radiolarla. Springer-Verlag, New York. p. 155-166.

Be, A.W.H. \& 0.R. Anderson. 1976. Gametogenesis in planktonic foraminifera. Sclence 192: 890-892.

Be, A.W.H., O.R. Anderson, W.W. Faber Jr. \& D.A. Caron. 1983. Morphological and cytoplasmic fine structure sequence of events during gametogenesis in a planktonic foraminifer, Globigerinoldes sacculifer (Brady). Micropaleonto1. 29: 310-325.

Davis, P.G., D.A. Caron \& J.McN. 1978. Oceanlc amoebae from the North Atlantic: Culture, distribution, and taxonomy. Trans. Amer. Micros. Soc. 96: 73-88.

Fisher, R.A. \& F Yates. 1963. Statistical Tables for Biological, Agricultural and Medical Research. 6th ed. Hafner, Darlen, Connecticut. Guillard, R.R.L. 1975. Culture of phytoplankton for feeding marine invertebrates. In: Smith, W.L. \& M.H. Chanley (eds.), Culture of marine Invertebrate animals. Plenum Pub., New York, p. 29-60.

Lighthart, B. 1969. Planktonic and benthic bacterlovorous protozoa at eleven stations in Puget Sound and adjacent Pacific Ocean. J. Fish. Res. Bd. Canada 26: 299-304.

Singh, B.N. 1946. A method of estimating the numbers of soil protozoa, especially amoebae, based on their differentlal feeding on bacteria. Ann. App1. B1o1. 33: 112-119.

Spindler, M., O.R. Anderson, C. Hemleben \& A.W.H. Be. 1978. Light and electron microscopic observations of gametogenesis in Hastigerina pelagica (Foraminifera). J. Protozool. 25: 427-433. 


\section{APPENDIX III}

TECHNIQUE FOR ENUMERATION OF HETEROTROPHIC AND PHOTOTROPHIC

NANOPLANKTON, USING EPIFLUORESCENCE MICROSCOPY, AND

COMPARISON WITH OTHER PROCEDURES 


\title{
Technique for Enumeration of Heterotrophic and Phototrophic Nanoplankton, Using Epifluorescence Microscopy, and Comparison with Other Procedures $\dagger$
}

\author{
DAVID A. CARON \\ Woods Hole Oceanographic Institution, Woods Hole. Massachusetts 02543
}

Received 24 January 1983/Accepted 22 April 1983

\begin{abstract}
A new method is described that uses the fluorochrome primulin and epifluorescence microscopy for the enumeration of heterotrophic and phototrophic nanoplankton $(2$ to $20 \mu \mathrm{m})$. Phototrophic microorganisms are distinguished from heterotrophs by the red autofluorescence of chlorophyll $a$. Separate filter sets are used which allow visualization of the primulin-stained nanoplankton without masking chlorophyll $a$ fluorescence. thus allowing easy recognition of phototrophic cells. Comparison with existing epifluorescence techniques for counting heterotrophic and phototrophic nanoplankton shows that primulin provides more accurate counts of these populations than the fluorescein isothiocyanate or proflavine techniques. Accuracy is comparable to that with the acridine orange technique, but this method requires only one fitter preparation for the enumeration of both phototrophic and heterotrophic populations.
\end{abstract}

Heterotrophic microflagellates ( 2 to $20 \mu \mathrm{m}$ ) are a ubiquitous component of plankton communities $(6-8,10,17.25,28,35-37,40)$. Several studies have demonstrated the importance of these protozoa as predators for heterotrophic bacteria, chroococcoid cyanobacteria, and phototrophic nanoplankton $(12-15,20,21,23,28$. 32). Heterotrophic microflagellates play a role in the decomposition and remineralization of organic matter $(12,13,29,39)$ and are a potential food source for filter-feeding zooplankton (24). Although recent attempts have been made to incorporate these organisms into models of planktonic food webs $(26,30,33,36,42)$. most investigations of the plankton still make no effort to determine the number of these protozoa present in nanoplankton samples $(2,3)$; hence. all microflagellates are considered phototrophic or osmotrophic.

Major problems with counting heterotrophic microflagellates in natural samples have been the accurate enumeration of the total nanoplankton and the differentiation of the organisms which lack photosynthetic pigments. A variety of counting techniques have been used for the nanoplankton, including the classical Utermöhl settling technique (41). microscopic observation of live samples (35, 37. 40), scanning electron microscopy (4.34), and, more recently epifluorescence microscopy $(11.20,28)$.

The first three counting techniques listed

+ Contribution no. 5380 from the Woods Hole Oceanographic Institution. above have serious limitations with heterotrophic microflagellates. The Utermöhl technique underestimates nanoplankton concentrations by more than an order of magnitude (4. 11), presumably due to slow settling rates of small cells. Microscopic examination of live unconcentrated samples may be applicable in some situations, but it has been shown to underestimate the number of small flagellates due to restrictions on the magnification (4). The need to process samples immediately and to have high flagellate concentrations (to insure accurate and reproducible counts) renders this technique impractical for routine use. Scanning electron microscopy has been used successfully for studying nanoplankton samples, but it is time consuming and costly, and is impossible at sea.

A more important weakness of these techniques is their poor capability (or inability) for differentiating pigmented from nonpigmented nanoplankton. The taxonomic diversity of the heterotrophic nanoplankton has complicated this problem. Many phytoplankton taxa contain nonpigmented species (31), and therefore, cell morphology cannot be used as a tool to distinguish pigmented and nonpigmented organisms.

A more obvious method for distinguishing phototrophic from heterotrophic organisms is the presence or absence of photosynthetic pigments, a characteristic readily determined by epifluorescence microscopy. Several techniques involving epiffuorescence microscopy have recently been proposed (11, 20, 28). These techniques rely on secondary fluorescence of vari- 
ous fluorochrome stains (acridine orange $[\mathrm{AO}]$. 3-6-diaminoacridine hemisulfate [proflavine], and fuorescein isothiocyanate [FITC]. respectively) to make the heterotrophic nanoplankton visible and on the red autofluorescence of chiorophyll a to distinguish phototrophic nanoplankton. Ideally, it should be possible to distinguish fluorochrome from chlorophyll a fluorescence and to enumerate both groups of organisms from the same preparation. However. overlapping or interference of the emission spectra of the fluorochrome and chlorophyll $a$ may result in masking of the chlorophyll fluorescence, resulting in error in the estimation of the proportion of phototrophic to heterotrophic organisms. This problem is most apparent in the $\mathrm{AO}$ technique (11). in which fluorochrome and chlorophyll $a$ emission spectra overlap considerably. This necessitates two distinct counts on separate preparations: an unstained sample for chlorophyll $a$ fluorescence only (phototrophic nanoplankton), and a stained sample for total nanoplankton (phototrophs and heterotrophs). The number of heterotrophic organisms is then determined by the difference (11). The proflavine and FITC techniques have been proposed to permit both counts on a single preparation. However, the fluorescence of these fluorochromes must be distinguished from that of chlorophyll a by eye. and there can be considerable masking of chlorophyll $a$ fluorescence by these fluorochromes (11).

This paper describes an alternative staining procedure for simultaneously counting phototrophic and heterotrophic nanoplankton by epifluorescence microscopy. This procedure uses the fluorochrome primulin. which has excitation and emission maxima that are much lower than the corresponding maxima for chlorophyll $a$. allowing different filter combinations to be used to preferentially stimulate and observe either fluorochrome or chlorophyll $a$ fluorescence. This method minimizes masking of chlorophyll $a$ fluorescence and the resultant error in counting heterotrophic and phototrophic nanoplankton from a single preparation.

\section{MATERIALS AND METHODS}

All seawater samples were preserved with prefiltered $(0.22-\mu \mathrm{m}$ Millipore filter) $10 \%$ glutaraldehyde prepared in natural seawater to obtain a final preservative concentration of $1 \%$. Freshwater samples were preserved at the same final concentration by using $10 \%$ glutaraldehyde prepared in distilled water with $0.1 \mathrm{M}$ sodium cacodylate buffer $(\mathrm{pH} 7.0)$.

The fluorochrome primulin (Direct Yellow 59. Color Index 49000. Aldrich Chemical Co.) was prepared at a concentration of $250 \mu \mathrm{g} / \mathrm{m}$ ! in distilled water with 0.1 M Trizma-hydrochloride at $\mathrm{pH} 4.0$. since binding and Huorescence of the fiuorochrome occur optimally at acid $\mathrm{pH}$ 19l. The solution was prepared fresh and was filtered through a $0.22-\mu \mathrm{m}$ Millipore filter hefore each use. Each preserved sample $(10$ to $50 \mathrm{ml})$ was drawn down onto a $0.8-\mu \mathrm{m}$. $25-\mathrm{mm}$ Nuclepore filter prestained with irgalan black (22) at a vacuum not greater than $10 \mathrm{cmHg}(13.330 \mathrm{~Pa})$. A $0.5-\mu \mathrm{m}$. 25-mm Millipore fitter was placed underneath the Nuclepore filter to promote even dispersion of the sample on the Nuclepore filter (27). The filter was then rinsed with two 1 . $\mathrm{ml}$ portions of a rinse solution dedistilled water with 0.1 M Trizma-hydrochloride [ $\mathrm{pH} 4.0]$ filtered through a $0.22-\mu \mathrm{m}$ Millipore filter), flooded with the primulin solution, and stained for 15 min without vacuum. The stain was then removed by gentle vacuum, and the filter was rinsed with two 2-ml portions of the rinse solution. The filter was removed and placed on a thin film of immersion oil (Cargille type A) on a glass slide, specimen side up. One drop of oil was piaced on the center of the filter, followed by a cover slip.

A Zeiss standard microscope equipped with an HBO-50 mercury burner was used for all observations. A Neofluar $\times 100$ objective lens (Planachromat and Planapochromat lenses will not work) and $\times 10$ eyepieces were employed. A $\times 40$ objective was found to be insufficient to determine detail on small tless than 5 $\mu \mathrm{m}$ ) nanoplankton. Filter sets used for the observation of fluorescence were as follows: for primulin, a G365 exciter filter. an FT420 chromatic beam splitter. and an LP418 barrier filter (Zeiss filter set 487702): and for chlorophyll $a$ a a BP50-490 exciter filter. an FT510 chromatic beam splitter. and an LP520 barrier filter (Zeiss filter set 487709 . These filter sets were mounted in a filter insert housing (Zeiss 466301), which allowed their rapid exchange.

Two methods of enumeration were used. For estuarine and nearshore samples and laboratory cultures, microorganisms per field of view were counted. Fiejds were viewed first for primulin fluorescence to locate nanoplankton cells. and then for chlorophyll a Huorescence (by changing the filter set) to determine which of these cells were pigmented. The average number of cells per fiejd of view was converted to organisms per milliliter by knowing the sample volume $(\times 0.9$. due to dilution during preservation), the area of the field of view, and the area of the fiter covered by sample, using the equation: number of cells per $\mathrm{m}]=$ [ number of cells/field)(funnel area/field area)]/( $(0.9)$ (sample volume)]. For oceanic samples. repeated scans across the filter were made at $\times 1.000$. The length of each scan (in millimeters I was determined by using the mechanica! stage divisions, and the area observed was determined by the scan length muitiplied by the field diameter. Repeated interchange of the fitter sets during each scan allowed determination of pigmented and nonpigmented cells. Care must be taken when scans are made using the $\times 100$ Zeiss Neoftuar objective. This lens does not produce a completely flat fieid, and constant focusing is necessary to see cells near the edge of the field. The error generated by these two counting methods was comparable: the averaged coefficient of variation for both methods together was $10.8 \%$ for 80 population counts.

I compared the accuracy of the primulin staining procedure with hemacytometer counts of five clonal cultures of phototrophic microflagellates and eight clonal cultures of heterotrophic microflagellates. The species of algae used were Isochrysis galhana istrain ISO). Dunaliella tertiolecta (DUN). Monochnssis lath- 
eri (MONO). Chroomonas salina (3C), and Micromonas sp. (DW-8) from the culture collection of R. R. L. Guillard. Five of the heterotrophic microtlagellates were marine: two species were isolated from coastal waters off Woods Hole, Mass. (Paraphysomonas sp. and Bicoec'a sp.), and three species were isolated from the Sargasso Sea (Rhynchomonas sp. and (wo species of $B(d)$ ). The three remaining heterotrophs (Actinomonas sp. and two species of Bodo) were freshwater species isolated from Lake Ontario. All heterotrophs were cultured on a mixed bacterial flora enriched by adding $0.01 \%$ yeast extract to natural seawater or natural lake water. Phytoplankton were cultured in enriched seawater medium f/2 (19). Phytoplankton and protozoa were sampled during exponential growth and preserved in glutaraldehyde. Counts were made by using a Hausser Hy-Lite hemacytometer and with the primulin epifluorescence technique. Most samples were diluted for the fluorescence technique.

I also compared the existing procedures for epifluorescence microscopy used to enumerate phototrophic and heterotrophic nanoplankton. Natural samples from coastal and oceanic environments were counted by the AO technique (11), the FITC technique (28), the proftavine technique (20), and the primulin technique. There were minor changes in the other methods. (i) The Zeiss standard microscope equipped with an HBO-50 mercury burner was used instead of a $100-\mathrm{W}$ tungsten-halogen lamp (20) or an Olympus Vanox microscope (11). (ii) Protlavine was added before preservation for only three samples (20). and Cargille type A immersion oil was substituted for type LF (20). since use of the latter had no effect on the counts.

The emission spectra of acridine crange, proflavine. FITC. and primulin were examined by using a PerkinElmer MPF-3 fluorescence spectrophotometer. Emission spectra between 520 and $700 \mathrm{~nm}$ were recorded for all four fluorochromes irradiated at $470 \mathrm{~nm}$ with a slit width of $40 \mathrm{~nm}$. An emission slit width of $15 \mathrm{~nm}$ was used. The excitation wavelength and slit width were chosen to simulate the BP450-490 filter. The range of emission wavelengths represents visible light passing the barrier filter (LP520). The emission spectrum for primulin between 420 and $700 \mathrm{~nm}$ was examined at an excitation wavelength of $365 \mathrm{~nm}$ (slit width. $40 \mathrm{~nm}$ ). This excitation wavelength and slit width simulate the G365 filter, and the emission spectrum represents visible light passing the barrier filter (LP418).

\section{RESULTS AND DISCUSSION}

Determination of the number of phototrophic nanoplankton is vital to the accurate enumeration of heterotrophic nanoplankton. If chlorophyll $a$ fluorescence cannot be observed in an organism, it is counted as a heterotroph, and an incorrect assessment of the proportion of heterotrophic and phototrophic organisms resuits. Examination of unstained preparations for primary fluorescence of chlorophyll a remains the most effective method to determine the presence or absence of chlorophyll $a$, since no fiuorochrome is present to obscure chlorophyll a fluorescence $(6,7,11)$. However, potential problems with this technique include counting paired or multiple chloroplasts within a single organism as more than one organism. and underestimation of cell size (since the surrounding cytopiasm is often nonfluorescing). Furthermore, obtaining accurate counts of heterotrophs by determining the difference between total nanoplankton and phototrophic nanoplankton (AO technique: 11) is difficult in environments in which the phototrophs greatly outnumber the heterotrophs. Slide-to-slide variabiiity may also affect the ratio of phototrophs to heterotrophs, since the $\mathrm{AO}$ procedure requires the preparation and enumeration of two filters per sample.

The proflavine and FITC procedures were developed to allow simultaneous counting of phototrophic and heterotrophic nanoplankton by using a fluorochrome stain which does not mask the red chlorophyll $a$ fluorescence. These techniques have simplified counting of heterotrophic nanoplankton, but the emission spectra for these fluorochromes indicate a potential for masking of chlorophyll $a$ fluorescence.

Figure 1 shows the emission spectra of $\mathrm{AO}$. FITC, proflavine, and primulin under blue light excitation (Fig. 1B) and the emission spectrum for primulin under UV excitation (Fig. 1A). The unsuitability of $\mathrm{AO}$ as a means of identifying photosynthetic nanoplankton is shown by its relatively long wavelength emission spectrum. In theory, proflavine and FITC should not mask chlorophyll $a$, since their emission spectra (Fig. $1 \mathrm{~B})$ are similar and quite distinct from the peak of chlorophyll a fluorescence at $668 \mathrm{~nm}$ (18). However, the use of a single filter set with these fluorochromes means that the light from chlorophyll a fluorescence, albeit a different color. must be visible within the brightly fluorescing cytoplasm.

Primulin fluoresced brightly. with a maximum at ca. $425 \mathrm{~nm}$. when excited with UV light (Fig. 1A). Primulin-stained cells fluoresced a bluishwhite color under UV excitation. Flagella were visible on many cells in the seawater samples. although they were often not immediately apparent due to orientation or depth of fieid at $1,000 \times$. The fluorescence of primulin under biue light excitation (BP450-490, used for chlorophyll a excitation) is substantially reduced (Fig. 1B) relative to fluorescence under $\mathrm{UV}$ excitation (Fig, 1A), making chlorophyll a fluorescence more obvious in primulin-stained cells. Thus, an examination for chlorophyll a fluorescence can be made on the same specimen simply by changing the filter set, due to the relatively nonoverlapping excitation and emission spectra of primulin and chlorophyll. The efficacy of this procedure relies on a means of easy exchange of the two filter sets.

Shifts in the emission spectra observed in Fig. 


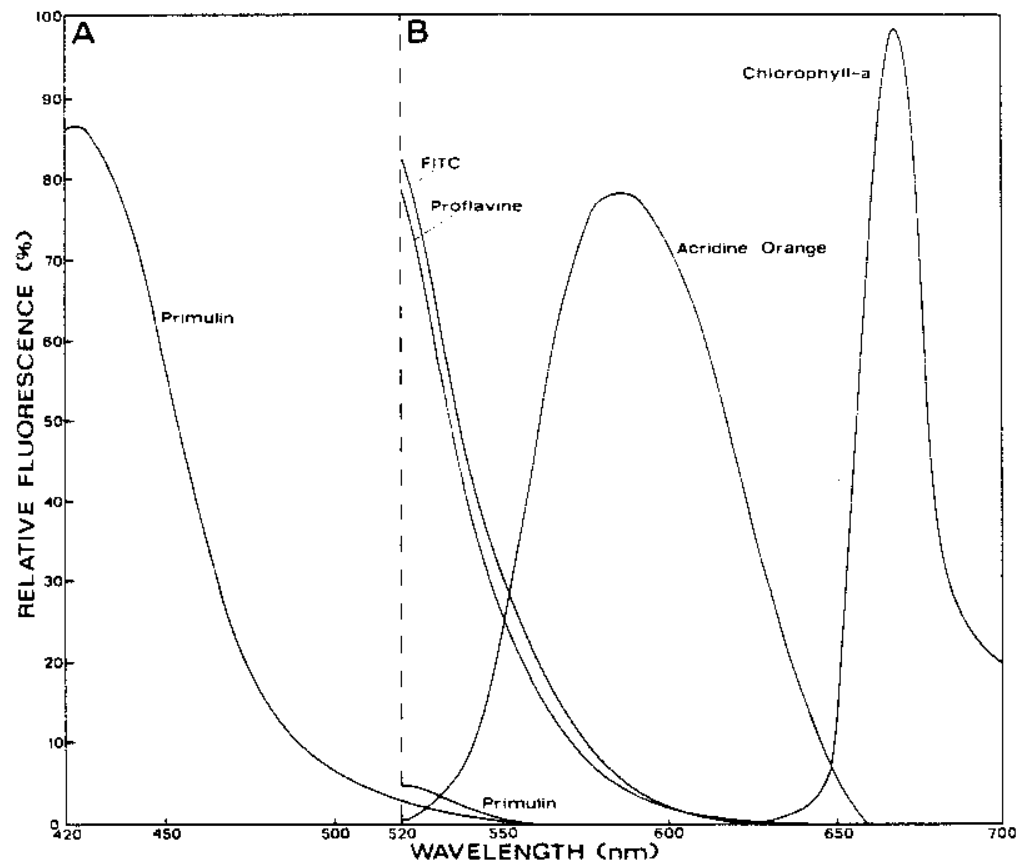

FIG. 1. Fluorescence emission spectra of primulin, protlavine, FITC. AO, and chlorophyll $a$. (A) Emission spectrum of primulin when excited at $365 \mathrm{~nm}$ with a slit width of $40 \mathrm{~nm}$. (B) Emission spectra of primulin. proflavine, FITC. and AO when excited at $470 \mathrm{~nm}$ with a slit width of $40 \mathrm{~nm}$. The same concentration of primulin was used for both types of excitation. The chlorophyll a emission spectrum was taken from French et al. (18).

1 may occur due to binding of the fluorochrome or changes in the exact spectral quality of the excitation beam. The extent of these differences is unknown. However, Haas (20) noted that proflavine caused detritus to fluoresce pink. This suggests a shift to longer emission wavelengths.

Staining characteristics of primulin. AO, FITC. and proflavine are shown for a small phytoflagellate (Micromonas sp.) in Fig. 2. Unstained preparations (Fig. 2A) show the red autofluorescence of chlorophyll $a$. Organisms stained with AO (Fig. 2B) fluoresce bright orange to red. masking chlorophyll $a$ fluorescence. Primulin-stained preparations (Fig. 2C) excited the UV light fluoresce brightly, but under blue light (Fig. 2D) fluorescence is greatly reduced. making the chlorophyll $a$ easily visible. Chlorophyll $a$ fluorescence of FITC-stained (Fig. 2E) and proflavine-stained (Fig. 2F) preparations was less apparent than for primulin-stained preparations. Although the colors of the FITC (green) and proflavine (yellow) are distinct from the red chlorophyll $a$ fluorescence, the intensity of the fluorochrome fluorescence masks that of chlorophyll a. especially in small cells (Fig. 2). Chlorophyll $a$ fluorescence in larger phototrophic nanoplankton is more intense, and not as easily masked by the fluorochrome.

A comparison between the counts obtained by hemacytometer and by primulin epifuorescence is given in Table 1 . The counts were not significantly different (Wilcoxon rank sum test, $\alpha=$ 0.05 ) for the microalgae and protozoa tested.

A comparison of the AO. FITC, proflavine, and primulin counts of 10 nearshore and oceanic samples is given in Table 2. Unstained preparations (no fluorochromes added) were counted for the number of phototrophic nanoplankton as part of the AO technique and were used as a means of comparing the counts of phototrophic nanoplankton for the FITC. proflavine. and primulin methods. The AO counts were assumed to indicate total nanoplankton (11) to which the other techniques were compared.

The results of the primulin technique agreed well with those of the $\mathrm{AO}$ technique. In one sample, the count of phototrophic cells was significantly greater than that in the unstained preparation, and in one sample, the total nanoplankton were significantly fewer than with the AO count. In contrast, the FITC counts indicated significantly fewer phototrophic cells than the unstained counts in nine samples. Total nanoplankton for this staining procedure were also significantly fewer than the AO counts in nine samples. indicating an underestimation of both phototrophic and total nanoplankton by the FITC technique. Averages for the 10 samples by the FITC technique were $56 \%$ of the number of 
$-228 a-$
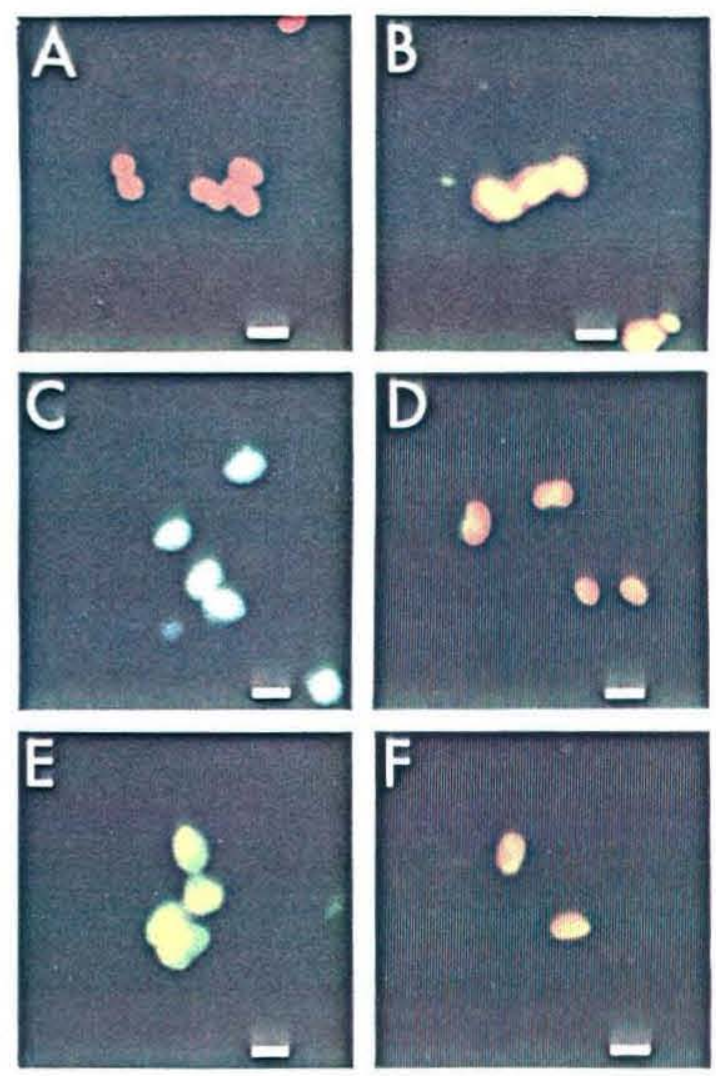

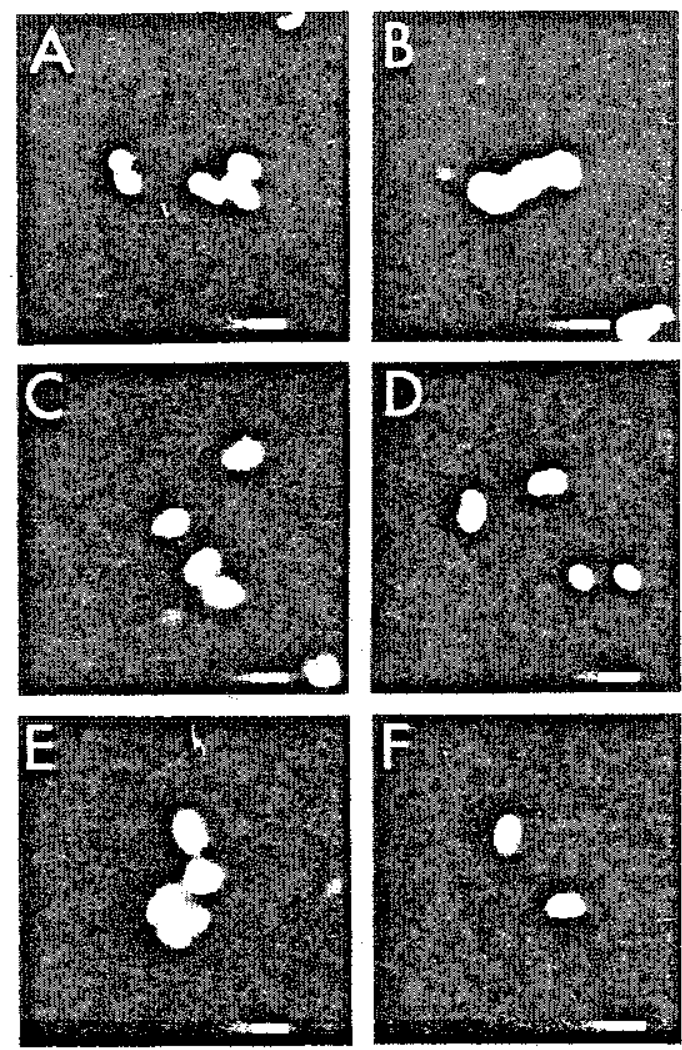

FiG. 2. Photomicrographs of .Micromonas sp. (A) Unstained preparation showing autofuorescence of chiorophylt. (B) AO-stained preparation. Note that the orange color of the AO masks the red chlorophyll fluorescence. $(C$ and D) Primulin-stained preparation irradiated with LV light (C) to preferentially excite primutin and blue light (D) to preferentially excite chlorophyll a. (E) FITC-stained preparation. (F) Proflavine-stained preparation. Bar, $2 \mu \mathrm{m}$.

phototrophic nanoplankton (relative to unstained preparations) and $64 \%$ of the number of total nanoplankton (reiative to the AO preparations). FITC stains some detritus intensely. Many organisms in the samples were associated with particles. and it is probable that they were not visible because of this high background fluorescence. This might explain why fewer phototrophic nanoplankton which should have been visible due to chlorophyll a autofuorescence) were observed in nine samples relative to the unstained preparations. Sherr and Sherr (28) noted a decrease in the number of heterotrophic and phototrophic nanoplankton (as shown by the FITC technique) in preserved samples of 46 and $18 \%$. respectively, after 4 weeks of storage at $5^{\circ} \mathrm{C}$, but they observed no decrease after $?$ weeks of storage. Aiternatively, the results for the FITC technique (Table 2) may indicate that these decreases occur sooner than 2 weeks for naturat samples.

Four protlavine-stained samples had significantly fewer phototrophic cells relative to unstained preparations. whereas only two samples had significantly fewer total nanoplankton than AO counts (Table 2). This suggests that some phototrophic nanoplankton were included in the counts of heterotrophs. Staining of detritus may also explain some of the discrepancies in the proflavine counts. Proflavine often causes detritus to fluoresce pink (20). leading to an inability to distinguish chlorophyll $a$ fuorescence in phototrophic organisms on or near particles. In one sample, the number of phototrophic cells exceeded that in the unstained preparation. This was the same sample that gave a higher phototroph count with the primulin method.

The inevitable result of overstaining with proflavine and FITC is a masking of chlorophyll $a$ fuorescence, since the same filter set is used for fluorochrome and chlorophyll $a$ excitation. Overstaining can cause the incorrect identification of phototrophs as heterotrophs, resulting in an underestimation of the number of phototrophs and an overestimation of the number of heterotrophs. Understaining can result in an underestimation of the number of heterotrophs and. in turn, in the total number of nanoplankton. since poorly stained cells may be overlooked. Both of these artifacts (underestimation of phototrophs and underestimation of total nanoplankton) are apparent in Table 2 for the protlavine and FITC procedures. Primulin allows slight overstaining of nanoplankton without significant masking of chlorophyll fluorescence due to the minimal overlap between primulin

TABLE 1. Comparison of direct counts of clonal cultures for tive species of photosynthetic flagellates and eight species of heterotrophic flagellates

\begin{tabular}{lcc}
\hline \multicolumn{1}{c}{ Species } & \multicolumn{2}{c}{$\begin{array}{c}\text { Direct count }\left(\times 10^{5} \text { cells per }\right. \\
\text { ml as measured by: }\end{array}$} \\
\cline { 2 - 3 } & Hemacytometer & Primulin \\
\hline Phototrophs & & \\
Isochrysis galbana & 4.09 & 4.03 \\
Dunaliella tertiolecta & 6.12 & 6.19 \\
Monochrysis luther & 3.74 & 3.81 \\
Chroomonas salina & 7.70 & 7.89 \\
Micromonas sp. & 82.8 & 86.9 \\
Heterotrophs & & \\
Paraphysomonas sp. & 2.72 & 2.44 \\
Bicoeca sp. & 2.15 & 2.22 \\
Rhyncomonas sp. & 2.91 & 2.67 \\
Bodo sp. 1 & 1.08 & 1.05 \\
Bodo sp. 2 & 10.2 & 10.1 \\
Actinomonas sp. & 1.87 & 1.80 \\
Bodo sp. 1 (freshwater) & 4.91 & 4.97 \\
Bodo sp. 2 (freshwater) & 0.24 & 0.20 \\
\hline
\end{tabular}


TABLE 2. Counts of photosynthetc (Pnanot, heterotrophic t Hananol, and total f nanol nanoplankton tor four nearshore and six ocennic stations ${ }^{2}$

\begin{tabular}{|c|c|c|c|c|c|c|}
\hline \multirow{2}{*}{$\begin{array}{c}\text { Sample descriouion (atate } \\
\text { and location) }\end{array}$} & \multirow{2}{*}{ Parameter } & \multicolumn{5}{|c|}{ Nanoplankion count in the following prepn: } \\
\hline & & Unstuined & $\mathrm{AO}$ & Primulin & FITC & Proflavine \\
\hline $\begin{array}{l}\text { Eel Pond } \\
\text { 10/8/82 } \\
\text { Woods Hole. Mass. }\end{array}$ & $\begin{array}{l}\text { Patano } \\
\text { Knano } \\
\text { Tnano }\end{array}$ & $4.12 \times 10^{3}$ & $5.45 \times 10^{3}$ & $\begin{array}{l}4.24 \times 10 \\
1.51 \times 10^{5} \\
5.75 \times 10^{9}\end{array}$ & $\begin{array}{l}1.86 \times 10^{2 *} \\
1.98 \times 10^{*} \\
3.84 \times 10^{3 *}\end{array}$ & $\begin{array}{l}2.70 \times 10^{3} \\
1.65 \times 10^{3} \\
4.36 \times 10^{3}\end{array}$ \\
\hline $\begin{array}{l}\text { Vineyaru Sound } \\
\text { lo/13/82 } \\
\text { Falmouth, Mass. }\end{array}$ & $\begin{array}{l}\text { Pnano } \\
\text { Knano } \\
\text { Thano }\end{array}$ & $5.08 \div 10^{3}$ & $6.86 \times 10^{3}$ & $\begin{array}{l}5.13 \times 10^{3} \\
1.71 \times 10^{3} \\
6.84 \times 10^{3}\end{array}$ & $\begin{array}{l}3.40 \times 10^{3} \\
1.70 \times 10^{3} \\
5.10 \times 10^{3}\end{array}$ & $\begin{array}{l}4.35 \times 10^{3 \times} \\
1.48 \times 10^{3} \\
5.83 \times 10^{3 \times}\end{array}$ \\
\hline $\begin{array}{l}\text { Head of Buzzards Bay } \\
10 / 228 \\
\text { Buzzards Bay, Mass. }\end{array}$ & $\begin{array}{l}\text { Pnano } \\
\text { Hnano } \\
\text { Tnano }\end{array}$ & $1.79 \times 10^{3}$ & $4.19 \div 10^{3}$ & $\begin{array}{l}1.94 \times 10^{3} \\
2.37 \times 10^{3} \\
4.28 \times 10^{3}\end{array}$ & $\begin{array}{l}1.46 \times 10^{3 *} \\
1.06 \times 10^{3} \\
2.52 \times 10^{3 *}\end{array}$ & $\begin{array}{l}1.77 \times 10^{3} \\
2.34 \times 10^{3} \\
4.12 \times 10^{3}\end{array}$ \\
\hline $\begin{array}{l}\text { Woods Hole Harbor } \\
\text { 1011/82 } \\
\text { Woods Hole. Mass. }\end{array}$ & $\begin{array}{l}\text { Prano } \\
\text { Hnano } \\
\text { Tnano }\end{array}$ & $3.04 \times 10^{3}$ & $5.50 \times 10^{3}$ & $\begin{array}{l}3.24 \times 10^{3} \\
2.14 \times 10^{3} \\
5.38 \times 10^{3}\end{array}$ & $\begin{array}{l}3.61 \times 10^{3} \\
2.68 \times 10^{3} \\
5.29 \times 10^{3}\end{array}$ & $\begin{array}{l}2.47 \times 10^{3} \\
2.31 \times 10^{7} \\
4.78 \times 10^{3 *}\end{array}$ \\
\hline $\begin{array}{l}\text { Sargasso Sea (surtace) } \\
10,2948 \\
34^{\prime} 44^{\circ} \times 70^{*} 00 \text { W }\end{array}$ & $\begin{array}{l}\text { Prano } \\
\text { Hano } \\
\text { Tnano }\end{array}$ & $2.104 \times 10^{2}$ & $8.06 \times 10^{-}$ & $\begin{array}{l}2.58 \times 10^{2} \\
7.03 \times 10^{2} \\
9.61 \times 10^{2}\end{array}$ & $\begin{array}{l}5.34 \times 10^{3} \\
2.54 \times 10^{2} \\
3.69 \times 10^{2 *}\end{array}$ & $\begin{array}{l}1.79 \times 10^{2} \\
6.38 \times 10^{2} \\
8.17 \times 10^{2}\end{array}$ \\
\hline $\begin{array}{l}\text { Sargasso Sea (surface) } \\
1030182 \\
\$ 3^{\circ} 57^{\prime} \mathrm{N} 70^{\circ}\left(0 \mathrm{~W}^{\prime} \mathrm{W}\right.\end{array}$ & $\begin{array}{l}\text { Pnano } \\
\text { Honno } \\
\text { Trano }\end{array}$ & $2.43 \times 10^{2}$ & $1.38 \times 10^{9}$ & $\begin{array}{l}3.66 \times 10^{2} \\
1.24 \times 10^{3} \\
1.6 \times 10^{3}\end{array}$ & $\begin{array}{l}1.60 \times 10^{2} \\
6.79 \times 10^{2} \\
8.40 \times 10^{2}\end{array}$ & $\begin{array}{l}2.17 \times 10^{2} \\
1.17 \times 10^{3} \\
1.38 \times 10^{3}\end{array}$ \\
\hline $\begin{array}{l}\text { Sargasso Sea (surface) } \\
10 / 3182 \\
3404 \mathrm{~N} 70^{\circ} 08^{\circ} \mathrm{W}\end{array}$ & $\begin{array}{l}\text { Puano } \\
\text { Hniano } \\
\text { Thano }\end{array}$ & $2.26 \times 10^{2}$ & $7.52 \times 10^{2}$ & $\begin{array}{l}2.34 \times 10^{2} \\
2.42 \times 10^{2} \\
4.76 \times 10^{2 *}\end{array}$ & $\begin{array}{l}9.18 \times 10^{4 *} \\
4.20 \times 10^{2} \\
5.11 \times 10^{2 *}\end{array}$ & $\begin{array}{l}1.44 \times 10^{2} \\
5.46 \times 10^{2} \\
6.90 \times 10^{2}\end{array}$ \\
\hline $\begin{array}{l}\text { Sargasso Sea (surface) } \\
11 / 82 \\
35^{\circ} 40^{\prime} \times 69^{\circ} 33^{\circ}\end{array}$ & $\begin{array}{l}\text { Pnano } \\
\text { Hnano } \\
\text { Thano }\end{array}$ & $2.27 \times 10^{2}$ & $1.19 \times 10^{3}$ & $\begin{array}{l}3.33 \times 10^{2+} \\
6.63 \times 10^{-2} \\
9.36 \times 10^{\circ}\end{array}$ & $\begin{array}{l}1.39 \times 10^{2} \\
4.60 \times 10^{2} \\
5.88 \times 10^{24}\end{array}$ & $\begin{array}{l}3.51 \times 10^{2+} \\
9.00 \times 10^{2} \\
1.25 \times 10^{3}\end{array}$ \\
\hline $\begin{array}{l}\text { Sargasso Sea (20 meters) } \\
11 / 2 / 82 \\
3626^{\prime} \mathrm{N} 69^{\circ} 14 \text { w }\end{array}$ & $\begin{array}{l}\text { Pnano } \\
\text { Anaro } \\
\text { Trano }\end{array}$ & $5.10 \times 10^{2}$ & $9.68 \times 10^{2}$ & $\begin{array}{l}4.87 \times 10^{2} \\
4.50 \times 10^{2} \\
9.37 \times 10^{2}\end{array}$ & $\begin{array}{l}3.56 \times 10^{2} \\
4.30 \times 10^{2} \\
7.86 \times 10^{2}\end{array}$ & $\begin{array}{l}5.24 \times 10^{2} \\
3.76 \times 10^{2} \\
9.60 \times 10^{2}\end{array}$ \\
\hline $\begin{array}{l}\text { Continental shelf edge } \\
\text { (surface) }\end{array}$ & Prano & $5.44 \times 10^{3}$ & & $4.67 \times 10^{3}$ & $1.17 \times 10^{3 *}$ & $3.09 \times 10^{3 *}$ \\
\hline $\begin{array}{l}11 / 482 \\
79^{\circ} 43^{\prime} \times 70^{\circ} 13^{*} W\end{array}$ & $\begin{array}{l}\text { Hinano } \\
\text { Tnano }\end{array}$ & & $6.43 \times 10^{\circ}$ & $\begin{array}{l}1.68 \times 10^{3} \\
6.35 \times 10^{5}\end{array}$ & $\begin{array}{l}1.67 \times 10^{3} \\
2.84 \times 10^{3 \times}\end{array}$ & $\begin{array}{l}2.87 \times 10^{3} \\
5.96 \times 10^{3}\end{array}$ \\
\hline
\end{tabular}

"Couns of unstanted and $\mathrm{A}$ (O-staned preparations were used us an indes of Pran and Thano for comparison of the FITC. protlavine and primutin tectniques. An asterisi is indicates a signitiondy bwer count (Wicoxon rank sum test, $\alpha=0.05)$ relative to the unstaned or $A O$ count. A plus $1-1$ indicates a significuntiy higher count than the unstained or AO count. The Eel Pond. Head of Buzzards Bay and Woods Hole Harbor samples were stained with prof avine before preservation 120 ). The remaining samples were staind atter preservition.

and chlorophyll exciation and emission spectra.

Masking of chlorophyll a fluorescence may be augmented by the gradual loss of the intensity of chlorophyll a tuorescence in preserved sam. ples. and by the predominance of small tless than $5 \mathrm{~mm}$ ? phototrophic organisms. The latier situation was noted by Davis and Sieburth (11), who observed fewer phototrophic nanoplankton when using proflavine trelarive to the unstained AO technique). This difference was particularly acute for cells ? to $3 \mu \mathrm{m}$ in diameter. The Sargasso Sea samples enumeraled in this study were 4 to 3 days old when counted. and botin age and small cell size may have caused some of the observed discrepancies among techniques (Table 2).

The primulin technique proposed here provides a more accurate method falthough slightly more complicated than the FIC and profavine techniques for the enumeration of photorrophic and heteromophic nanoplankton. The use of two filter sets which can be easily and quickly exchanged is a necessity for the primulin method. This is not a requirement for the proftavine and FITC methods. Prohavine may atso be used to count bacteria present in a sample simulaneous- 
19 (20). although these counts appear to be inferior to DAPI counts IP. W. Johnson and J. M. Sieburh. personal communication, Although primulin thas been used to itentify digae (5). its accuracy for bacterial enumeration is doublul (umpublished datu). The AO method provides accuracy compurable to that of the primulin method, but the need for two preparations per sample and other potential problems previously mentioned reduce its usefulness relative to the primulin method.

A recent goal of direct counting techniques for heteromophic nanoplankton has been an accurate appraisal of the number of bacterivorous microfagellates in plankton communities 117 , 28). As with most assemblages of organisms based on size classes, however, the heterotrophic nanoplankton is a heterogeneous assemblage. In addition to bacterivorous microflagellates and their cysts (recent work by Fenchel [16] suggests that cysts are of minor importance for nearshore communities), some microflagellates are also capable of ingesting phytoplankton nearly their own size (20). The heterotrophic nanoplankton may asso include such diverse groups as the gametes of plankionic protozot or metazod 11 . 38) and those of brown atgae and phycomycetes (31). Another unknown is the percentage of chlorophyll-containing microflagellates which partially or mosriy function as heterotrophs $(14)$. At present, these complications warrant caution in the use of direot couns as an unequivocal measure of bacterivorous microflagellate densities and in the subsequent use of these numbers to estimate the impact which microprotozos have on natural baterial assembiages 117,28 .

Most-probable-number cultural methods generally yield estimates of bactirivorous nicrofagellates well below direct counts in oceanic waters ( 25 : unpublished data). This is due in part to an inability to cuture fasidious species of bacterivorous protozod present in the open cean. Fairly close agreement between mostprobable-number estimates and direct counts has been observed for inshore waters (1?). These latter results suggest that at least for inshore enviromments. the relative imporance of bacterivorous microflagellates in the heterotrophic nanoplankton may be high. A more complete characterization of the trophic modes of microflagellate species in all plankton communities awaits investigation. At present, direct counting procedures represent the hest available techrique for the rapid and accurate estimation of this component of planktonic communities, and a means of investigating trophic relationships among planktonic microorganisms $(6,7)$.

\section{ACKNOWLOGMENTS}

Simport for this work was providad toy the Join Program in Biological Oceanography between the Woods Hole Ocenno-

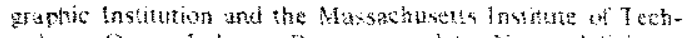

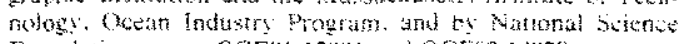

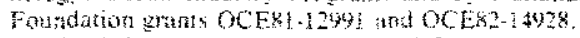

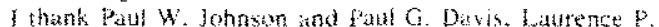
Madin. Burry Sherr. Evelyn Shers. and bohn M. Sichurth for criticaly randing the manusiript, and Catherine M. Cutat for whering of the Saruasio bea samples.

\section{DTERATIRE CTIS}

1. Be. A. W. H. and D. R. Aatersan. 1976. Gametogenesis in planktonic forminifera. Solence $192.890-892$.

3. Bets, J. R.. W. M. H. Keid. and G. I. Stewart. iy?

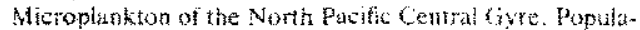
ion structure and abundanct. June. 197?. Int. Rev. Cresamten Hydrotiol. 60:607-6.36.

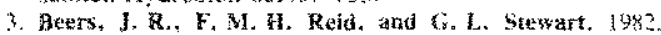
Seasonal abundance of the mitroplatikitus population in the North Pacifo central gyre, Deep Sea Res 29:27?+245.

4. Bowth, B. C.. I. Lewin and R. E. Norris. I 9 at. Nantplankton species predominant in the subartic Pacilic in Maty and June 1978 . Deep Seas Res. 24:185-7ik.

5. Brock. T. D. 1978. Use of fuorescence miarsicopy for quantifing movoplanken, especialy flamentous buegreen algate. Linnol. Oceanogr. 23:15\%-160.

6. Barney. C. M., F. G. Davis, M. Mohnson, and J. M. \$returth. 1981 . Dependence af dissolyed carbohydrate coneentrations upan smatl scale nunoplankton and bucte. roplankton distributions in the Western Sargasso Seat. Mar. Biol. 65:289-296.

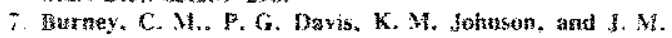
Siebarth. 1982. Diel refutionship of microhial Tophic groups and in stu dissolved carbohydrate dyommes on the Curibben Sea. Mar. Bol. 67:311-322.

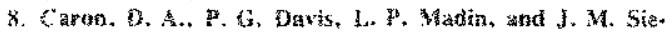
burh. 1982. Hateromophic basteria and bastervorous

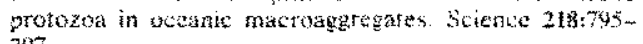
797.

4. Comr. 特. J. 1961. Binlogical stains. The Wittiams d Wikins Co. Bathmore.

10. Cavis, P. G., D. A. Caron. and J. M. Sieburtis. 197 .

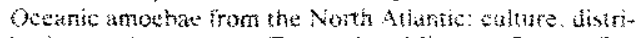
bution. and taxonomy. Trans. Am. Microse, 5oc, 97:?8dx.

11. Davis. 3. $\mathrm{G}_{n}$ and 3. M. Siebusth. 1982. Detferentiation of

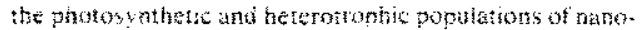
plankters by epiftuoresence michoxsops. Ann. Inst.

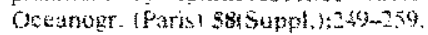

12. Fenchel, $T$. I979. Situdios on the decumpostios of organio vetritus derived from the turte grass Thuitsotu lewr ifintm. Limnd. (Jeanugr. 15:14-2i\}.

13. Fenchel. T. 1977. The significaned of bacriorous protozos in the microbial communty of detrital fartictes. p.

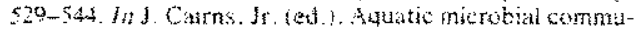
nities. hintand Publishing. New York.

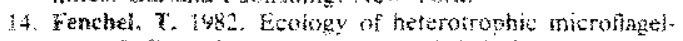
kates. I. Some important torms and their functional morphology, Mar. Ecol. Prog. Ser K:211-23:

15. Fenchet. T. 1982. Exology of hetenotrophic microflaget-

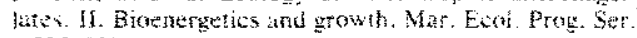
$4: 2=5-331$.

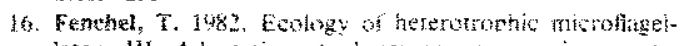
lates. III. Adaptations io heterugeneous environneris. Mar. Evol. Prong, Ser. $4: 35-33$.

17. Fenchel, T. 1982. troiog: oi heterotrophic microfageilates. IV. Quntitative occurrence and importance as bacterial consumers. Mar. Ecol. Frog. Ser. 9:35ma2.

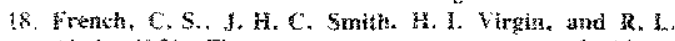
Airth. 1956. Fiwhesence-spectrum curves of chlorophylls pheophytins phyoorythrins, phyocyanins and hypericin. Plani physiol. 31:369-374.

19. Gamare, R. R. L. 1975. Cuilure of phytoplatkton for feeting marine invertebrates, p. 2y-mbtit w. L. Smint and $\mathrm{M}$. H. Chanle ied. . Culture of marine invertebrate animals. Plonum Press. Net lort 


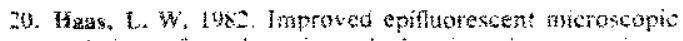
technique for otextring planktenic micro-myanisns.

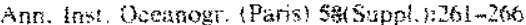

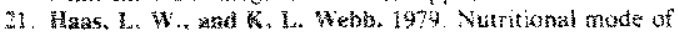
seyeral non-pigmeted misuldaghtates from the York

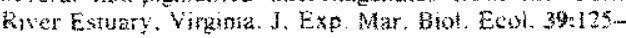
134.

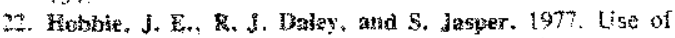
Nuciepore fitters for counting bacteriat by fuorescence microscopy. Appl Environ. Nerobial. 33:1225-122s

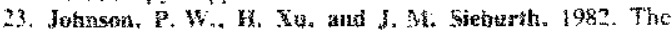
utilization of chrowcosevid cynonacteria by marine proiozocplankon but not by salatroid copepods. Arn. lnst.

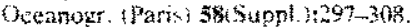

24. Kopstov, A. 1. A. F. Fasternak, and Y. V, Mniseyer, 1081. Consumption of zoollagellates by planktonic urganisms. Ceanology 21:269-271.

25. Lighthart. 3. 1969. Plankwic and benthic bacteriovoress protizon at eleven stations in Puget Sound and adjacent Pacific Oetat. J. Fish. Res. Board Can. 26: $299-304$.

26. Ponteray, L. 8. 1979, Secondary production mechanisms of continentast shetf communities. $5,163-186$. In R, J. L wineston ted.l, Ecological procestes in coastal and Marine systems. Plerum Press. New Fork.

27. Porter, K. G.. and $Y . S$. Feig. 19x0. The use of DApl tist identifyng and sounting aquatic microfora. Limnot. Oceanigr. $25943-946$.

28. Sherr. B.. and $\mathrm{E}$. Stuers, 1983, Enumeration of heterotrophic microprotazoa by epiftuorescence mictoseony. Estuarine Coastal Shelf Sci. 16:1-7.

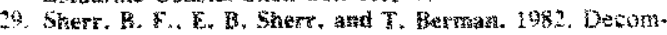
posituon af organis detritus: a selective role for microflagallate promona, Limnol. oceanugr. $37,765-764$.

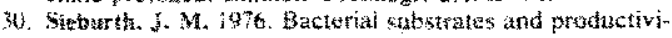
in in marine exyystems. Anat. Rav. Ecol. Syst. 7.259. 385

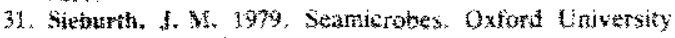
Press, Yotk.

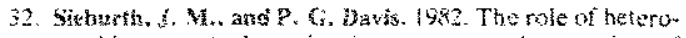
trophic natnoplatkion in the yrazing and ntarturing of phanktonic oncteria in the Sarpisso and Carboben Sea.

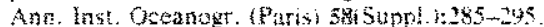

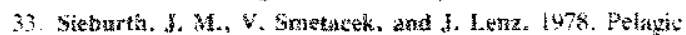
tcosysten structure: heterotronhic fompartments of the plankton and their relationship to plankton size fractions. Limnol Ocenogr. 23:1256-1363.

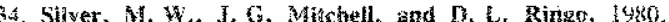
Silueveus nanoplankion. H. Newly discovered cystis and abundant chonolugellates from the Weddell Sean Anarction. Mar. Biol. $58: 211-31 \%$.

35. Sorokth. Y. 1. 1977. The heterotrophic phase of plankton sucuession in the Japar Sea. Mar. Biol, \$1:107ml17.

36. Sorokin, Y. 1. 1981 . Microheteromophe organisms in ma. rine ecosystems. F. $293-342$. In A. R. Longhurst ted. Analysis of marine exosystems, Afademic Press, London.

37. Serokin. Y. 1., and Y. E. Kogelschatz. 1979. Analysis of heterourophic microplankton in an upwelling area. Hydrobiologia 6ris: 195-208.

39. Spinder, M, O. A. Anterson, $C$. Kemlebea, and A. W. H. Be. 1978. Light and electron microscopic obser. vations of gamelogenesis in Hustigerina pelayict Ifora. minhiferal. 3. Protozool. 25:427-433.

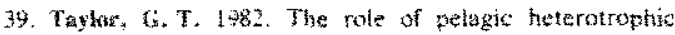
protozoa in nutrien eveing: A review. Annates last. Ocenogr. (Paris) 581 Sippl, $) \div 227-241$.

40. Tumaniseva, N. B., and Y. I. Sornkin. ly7\%. Microzoo flantion of the equatotial wowelling in the Eastern Pacitic Ocoan. Poi. Arch. Hydrotol. 34 Suppl. $9277-280$.

41. Utermohl H. 105\%. Zur Varvall Kommung der Quantitativen ltytoplankton-Methotiz. Mitt. Int. V⿺r. Theor. Angew. Limnoi $2: 1-38$

42. trophic proessise into the classical paradign of be planktunc foul web. Kialer Merestursh. 5:1-28. 
APPENDIX IV

HETEROTROPUIC BAGTERIA AND BACTERTYOROUS P2OTOZOA IN OGRANIC MACROAGGREGATES 
Reprint Series

19 November 1982. Volume 238, pp. 795-797

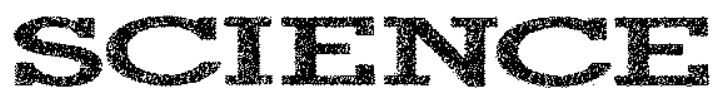

\section{Heterotrophic Bacteria and Bacterivorous Protozoa in Oceanic Macroaggregates}

Davis A. Caron, Paul G. Davis, Laurence P. Madin, and John McN. Sieburth

Copyright 1982 by the American Association for the Adyancement of Science 
Heterotrophic Bacteria and Bacteriworous

\section{Protozoa in Oceanic Macroaggregates}

Abstract. Oceanic macroaggregates (manine snow and Rhizosolenia mats) sampled from the Sargasso Sea are associated with bacterial and protonoan populations up to four orders of magnitude greater than those present in samples from the surrounding water. Filamentous, curved, and spiral hacteria constinted a higha? proportion of the bacteria associated with the particles than were fowd amang bacteria in the surrounding water. Protozon populations were dominated numbically by heterotrophic microfagellates, bat ciliates and amoebas were also ob. served. Macroaggregates are highly enriched heterotrophic microenwiroments in she oceans and may be significum for the cycling of particulate ortganic matter in planktonic food chains.

Macroscopic aggregates appear to be ubiquitous in the planktonic environment. Where they provide enriched microenvironments of nutrients and organic carbon for both autotrophic and heterotrophic processes in the oligotrophic ocean $(j-3)$. They may be nutritionally valuable for zooplankton and nekton grazing on them $(4,5)$ and are important in the fux of organic carbon to the deep sea $(3,6,7)$. Despite qualitative visual observations of high concentrations of bacteria and protozoa on macroscopic aggregates $(8)$, the potential importance of heterotrophic microorganisms in these microenvironments has roceived litle at. tention $(3,9)$, We now report the results of a preliminary examination of marine snow (datrital agxregates of heterogeneous origin) and Rhizosolemia mats (1. 10) collected in the southern Sargasso Sea by divers. Bacteria and bacterivorous protozoa in these microconmunities occurred in densities 10 to $10^{4}$ times that of the same populations in the surrounding water.

Samples of marine snow and Rhizosim lenia mats were collected by divers from the surface to $25 \mathrm{~m}$ depth at three locations in the mid-Atlantic (Table 1) on R.V. Allanis cruise 109-1II (August 1981). Rhizosolenia mats are composed of two cohabiting species of this diatom genus (1) that form discrete. conesive patches, approximately 2 to $5 \mathrm{~cm}$ in diameter. in the water. Marine snow may originate from various sources (4, I113). We have identifed two sources of tabile organic material that may give rise to marine snow in the oligotrophic ocean. The first are the mucus feeding webs made by thecosomatous pteropods to capture ricrozooplankton and phytoplankton (14). We observed numerous spherical or oval mucus bubbles, 1 to 4 $\mathrm{cm}$ in diameter, some of which had the pteropod Creseis virgula hanging beneati them. Where abandoned by the pteropods, these webs cunstinute a nass of organic carbon aiready inoculated with microorganisms. The second potential source of marine snow is suggested by our experience in collecting cterophores (15). When disturbed, these animals slough sheetlike vells of mucus into the water. We do not yet know if this is a normal cleansing procedure, as in corals. or a response to stress, but the quantity of mucus released suggests that this material could be an important source of marine snow

Sterile $20 \mathrm{ml}$ plastic syringes were used to sample Rhiosolenia mats and marine show so as to minimize contami - nation and reduce the volume of surrounding water while allowing collection of weakly attached microbial popula tions. Sample volumes of diatom mats and marine snow ranged from 0.4 to 5.8 mi. We coutd identify approximately half of the marine snow aggregates as abandoned pteropod mucus wobs by their shape and texture; the resi of the aggregates were unidentifable.

Tubie 1 gives the results of direct epifuorescence counts of bacteria total aanoplankton theterotrophic and photosynthetic fagellates) (16), and Trichodesmium spp. fildments and Rhizosolenia spp. frustules, and most probable number (MPN) culural estimates for protozoa on marine snow and Rhizosolenia mat samples. Bacteria were counted by staining with $4^{\prime}$,6-diamidino-2phenylindole (17) and total naroplankton by staining with acridine orange (16). We estimate that in the initial collection. the aggregates were diluted 1.5 to 6 times with surrounding water and that population densities of microorganisms for ag. gregate samples are therefore slightly underestimated. Aggrogare volume is probably a poorer measure of the actual size of the miscobial habitat than is total surface area of the aggregate. Unforthnately, the convoluted structure of the aggregates makes the latter parameter impossible to rneasure.

Total bacterial densities in the aggregate samples exceeded densities of free bacteria by two to more than 100 times (without correcting for aggregate dilution by surrounding water), averaging an 18 fold enrichment over bacterioplankton concentration (18). Aggregate and surrounding water samples also differed in the distribution of the morphological types of bacteria. Noncoccoid forms (rods, spirals, filaments, and curved rods) constituted 54 percent of the bacteria in the aggregate samples, but only 21

Table 1. Direct microscopic counts (epifuorescence) and most probable number (SPN) cultural estimates of the microorganisms present on macroaggregutes sampied at three stations in the southern Sargasso Sea $24^{\prime \prime 3} 30^{\prime} \mathrm{N}$. $53^{\circ} 0^{\prime} \mathrm{W}: 24^{\circ} 39^{\prime} \mathrm{N}$. $62^{\circ} 02^{\prime} \mathrm{W} ; 24^{\circ} 30^{\prime} \mathrm{N}$. $68^{\circ} 33^{\prime} \mathrm{W}$ ). Controls (surrounding water) were collected at $1 \mathrm{~m}$ and at $35 \mathrm{~m}$ in acid-rinsed ( $\mathrm{N}$ HCl Niskin bottes. UN indicates that no organisms were observed at the lowest dilution.

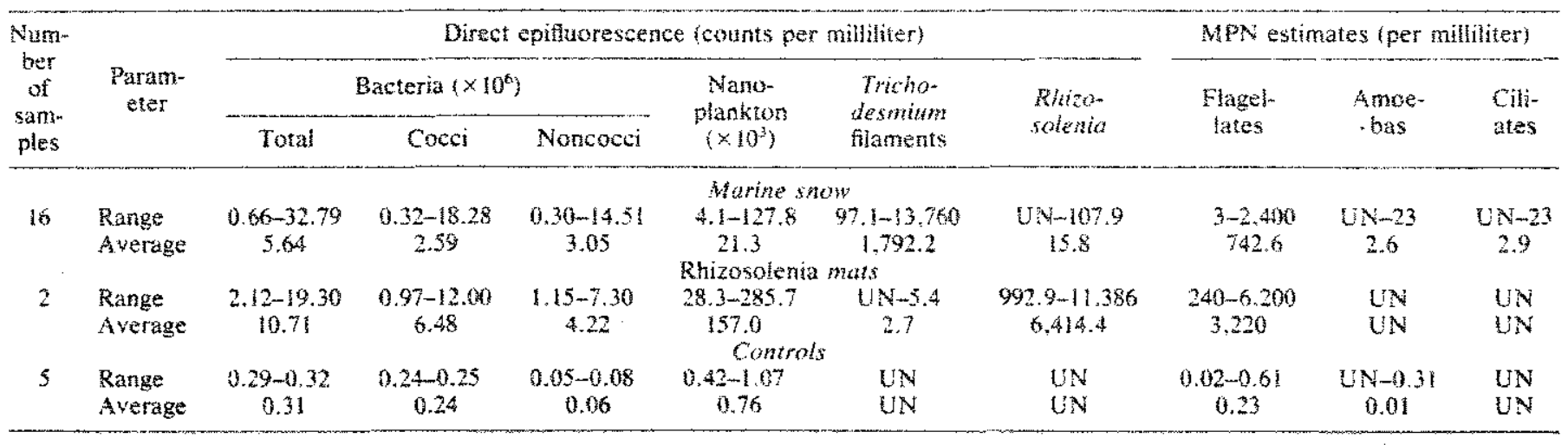


percent of the bacterioplankton samples. The noncoccoid cells in the aggregates included many extremely long filamentous and spirochete-like bacteria never observed in the surrounding water (Fig. 1, A to C). Therefore. numerical differences between bacterioplankton populations and bacterial populations on aggregates actually underestimated differences in bacterial biomass. As judged from bacterial volume estimates in aggregate and control samples. bacterial biomass would be, on average, 43 times greater than control for marine snow and 66 times for Rhizosolenia mats (19).

Previous estimates of bacterial concentrations on particles (including marine snow) have been relatively lowequal to or less than typical concentra- tions of bacteria from the water $(3,9,20$. 21 ). These low estimates may be due to a number of factors. including the age of the aggregates (that is. the stage of microbial colonization) or the amount of labile organic material initially present in the aggregate, but in some cases may be due to inaccuracies of the enumeration iechniques (22).

Direct counts of total nanoplankton (2to $20-\mu \mathrm{m}$ cetls) in the aggregates ranged from $4.1 \times 10^{3}$ to $285.7 \times 10^{3}$ cells per milliliter, exceeding the population in the surrounding water by five to more than 370 times. These populations contained both photosynthetic forms and heterotrophic protozoa, but samples were not examined quickly enough to determine the relative numbers of these subgroups
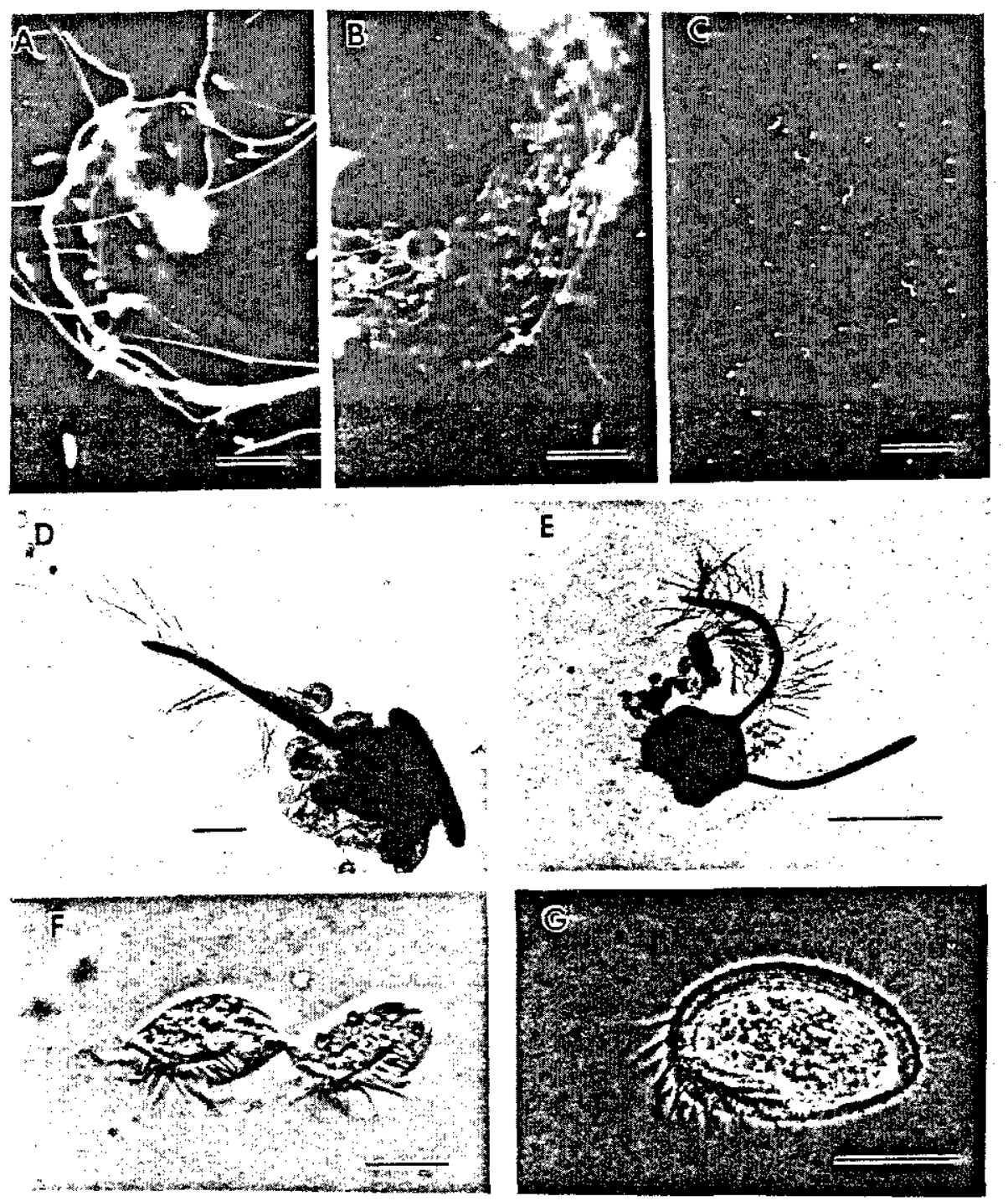

Fig. 1. Bacteria and protozoa associated with marine snow. (A to C) Epifluorescence photomicrographs of diamidinophenylindole-stained bacteria associated with marine snow $t \mathrm{~A}$ and $B$ ) and free bacteria in the surrounding water (C). Scale bars, $10 \mu \mathrm{m}$. (D to G) Representative protozoa cultured from marine snow. Electron micrographs of ammonium molybdate-stained specimens of the flagellate Paraphysomonas imperforata (D) and an unidentified biflagellate (E) cultured from mucus of the ctenophore Leticothea multicornis. Scale bars. $1 \mu \mathrm{m}$. The ciliates Ettplotes sp. (dividing form. differential interterence microscopy) (F) and Peritromus sp. (phase-contrast microscopy) (G) cułtured from marine snow. Scale bars, $50 \mu \mathrm{m}$.
(23). Larger phytoplankters consisted almost entirely of species of Trichodesmium or Rhizosolenia. Trichodesmium was present in high densities in all marine snow samples, whereas Rhizosolenia was observed in only two marine snow samples.

Enumeration of protozoa was done by the MPN cultural technique (24). Bacterivorous flagellates were the most preva. lent of the cultured protozoa. Approximately 50 percent of these were bodonids, but other small (less than $5 \mu \mathrm{m}$ ) mono- and biflagellates such as Paraphysomonas imperforata (Fig. 1, D and E) were present. Estimated flagellate density was highly variable 3 to 70.000 cells per milliliter), but was demonstrable in all samples. Numbers of heterotrophic flagellates from the macroaggregates exceeded the average MPN estimates of protozoa from the surrounding water by 1 to 4 orders of magnitude. Amoebas, primarily of the family Paramoebidae. and bacterivorous ciliates were less common, ranging from 3 to 23 cells per milliliter when present (25). Amoebas and ciliates were not always found in the culture with the lowest dilution (representing $0.1 \mathrm{ml}$ of the initial aggregate sample). However, their numbers may still be greater than the reported values for bacterivorous ciliates and amoebas from free water samples $(24,26)$. Direct epifluorescence counts of total nanoplankton exceeded the cultural estimates of protozoa in all cases, presumably because of the presence of photosynthetic forms and of heterotrophic flagellates that did not grow in culture.

The different aggregate samples varied considerably in counts of bacteria, nanoplankton. and larger phytoplankton. This may be due partly to the degree of dilution of aggregates during collection. but differences in the microbial populations on the aggregates would also be expected because of differences in the composition and colonization histories of the aggregates.

Our preliminary investigation of the microbiological populations associated with marine snow and Rhizosolenia mats indicates that these aggregates can provide a microenvironment of elevated heterotrophic microbial activity. These populations may serve directly as a food source for surface-dwelling and deep-sea organisms that feed on or in the aggregates. Bacteria and protozoa may be more nutritionally important than the digestion-resistant phototrophs that also characterize marine snow $(3,27)$. Microbial activity may increase the overall nutritional value of the aggregates to grazers by reducing the carbon-to-nitro- 


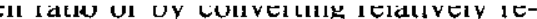
fractor organic compounds into digestible material or recyclable nutrients (2). Finally, high bacterial concentrations in macroaggregates may explain the occurrence of bacterivorous ciliates in an environment where bacterioplankton concentrations may be too low to support ciliate growth (28). Some species observed in this study are more typical of a benthic than a planktonic environment Ifor example, Peritromus (Heterotri- chida) and Euplotes (Hypotrichida) (Fig. $1, F$ and $G$ )]. Macroaggregates in the open ocean constitute microenvironments which, like the sea-air interface (29), are sites of elevated heterotrophic microbial activity in an otherwise oligotrophic environment.

David A. Caron Woods Hole Oceanographic Institution, Woods Hole, Massachusetts 02543

Paul G. Davis Department of Zoology, University of Rhode Island, Kingston 02881

LAURENCE P. Madin

Woods Hole Oceanographic Institution JoHn McN. Sieburth

Graduate School of Oceanography, University of Rhode Island

\section{References and Notes}

I. E. J. Carpenter et al. Limnol. Oceanogr. 22. 739 (1977).

2. A. L. Shanks and J. D. Trent, ibid. 24, 850 (1979).

3. M. W. Silver and A. L. Aljdredge, J. Mar. Res. 39, 501 (1981).

4. R. P. Gerber and N. Marshall, Bull. Mar. Sci. 32. 290 (1982).

5. B. H. Robison, personal communication.

6. D. A. Fellows, D. M. Karl, G. A. Knauer, Deep-Sea Res. 28. 921 (1981).

7. A. L. Shanks and J. D. Trent, ibid. 27A, 137 (1980).

8. J. D. Trent, A. L. Shanks, M. W. Silver, Limnol. Oceanogr. 23, 626 (1978).

9. H. W. Ducklow and R. Mitchell, ibid. 24. 715 (1979).

10. A. L. Alldredge and M. W. Silver, Mar. Biol. 66, $83(1982)$.

11. A. L. Alldredge, Limnol. Oceanogr. 21, 14 (1976).

12. S. L. Coles and R. Strathmann, ibid. 18, 673 (1973).

13. L. R. Pomeroy and D. Deibel, ibid. 25, 643 (1980).

14. R. W. Gilmer, Science 176, 1239 (1972).

15. G. R. Harbison and L. P. Madin. Oceanus 22, 18 (1979).

16. P. G. Davis and J. McN. Sieburth, Ann. Inst. Oceanogr., in press.

17. K. G. Porter and Y. S. Feig, Limnol. Oceanogr. 25, 943 (1980).

18. Bacterioplankton concentration averaged 3.06 $\times 10^{5} \mathrm{mi}^{-1}$ (standard deviation, $0.13 ; N=5$ ). Samples were taken by Niskin bottles ( 5 liters) at depths of $1 \mathrm{~m}$ and $35 \mathrm{~m}$.

19. Estimates were based on an average size of noncoccoid bacteria of $0.3 \mu \mathrm{m}$ diameter and 1.0 $\mu \mathrm{m}$ length for aggregate samples, and $0.3 \mu \mathrm{m}$ diameter and $0.6 \mathrm{\mu m}$ length for controls. Volume was calculated as for a cylinder. Cocci in both ageregate and controls averaged $0.3 \mathrm{\mu m}$ diameter and volume was calculated as for a sphere.

20. H. W. Jannasch, Limnol, Oceanogr. 18, 340 (1973).

21. W. J. Wiebe and L. R. Pomeroy, Mem. Ist. Ital. Idrobiol. 29 (Suppl.), 325 (1972).

22. Fixation and embedding for transmission electron microscopy (3) could result in the loss of bacteria weakly associated with the aggregates. Enumeration of colony-forming units $(9)$ cannot distinguish bacteria attached to a single particle

Samples were examined approximately 12 weeks after sampling-sufficient time for some degradation of chlorophyll pigments.

24. P. G. Davis, D. A. Caron, J. McN. Sieburth. Trans. Am. Microsc. Soc. 97, 73 (1978).

25. We cannot establish the absolute nature of bac terial predation for the cultured ciliates since they may have eaten heterotrophic flagellates growing in the cuitures. However, subsequen clonal culture has established the adequacy of bacteria as a food source for some of the common species.

26. Averages for ten stations transecting the North Atlantic at $24^{\circ} 30^{\prime} \mathrm{N}$ latitude on R.V. Atlantis for amoebas and bacterivorous ciliates

7. P. W. Johnson and J. McN. Sieburth, Ann. Inst. Oceanogr. (Paris), in press.

28. T. Fenchel, Microb. Ecol. 6. 13 (1980): Limnol. Oceanogr. 25, 733 (1980).

29. J. McN. Sieburth et al. Science 194. 1415 (1976).

30. Supported by NSF grants OCE80-24441 and OCE78-26388 and by the Woods Hole Oceanographic Institution education program. Ship support was provided by NSF grant OCE80-18514. We thank E. B. Small for ciliate identification. Contribution No. 5234 from the Woods Hole Oceanographic Institution.

19 April 1982; revised 3 August 1982 
APPENDIX $V$

CHROOCOCCOID CYANOBACTERIA IN LAKE ONTARIO:

VERTICAL AND SEASONAL DISTRIBUTIONS DURING 1982 
CHROOCOCCOID CYANOBACTERIA IN LAKE ONTARIO:

VERTICAL AND SEASONAL DISTRIBUTIONS DURING 1982

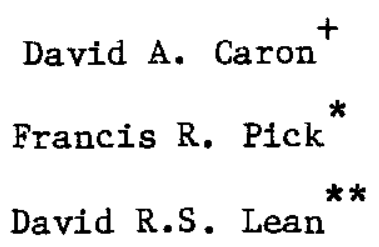

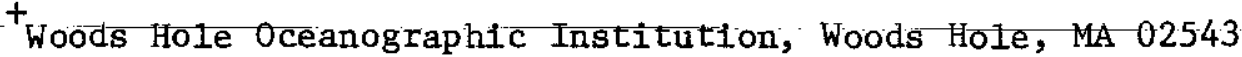

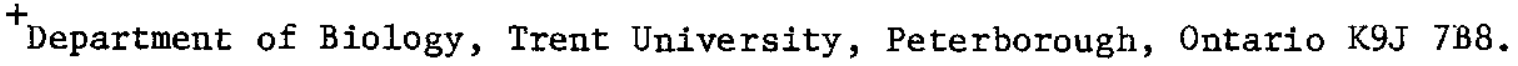

** National Water Research Institute, Box 5050 Burlington, Ontario L7R 4A6. 
ABSTRACT

Chroococcoid cyanobacteria (0.7-1.3 $\mu \mathrm{m}$ in diameter) were discovered to be a significant component of the Lake Ontario plankton. Using epifluorescence microscopy, the densities of these microorganisms were found to vary by 4 orders of magnitude with a single large peak in abundance $\left(6.5 \times 10^{5}\right.$ cells $\mathrm{mi}^{-1}$ ) corresponding to the time of maximum water temperature. The morphology and abundance of these cyanobacteria were similar to those previously found in oceanic systems. They constituted $10 \%$ of the bacterial numbers in the epilimnion during this period, approximately $40 \%$ of the biomass of prokaryotes less than $2.0 \mu \mathrm{m}$, and $30 \%$ of the biomass of all microorganisms less than $20 \mu \mathrm{m}$ in size. Size fractionation studies indicated that they were responsible for approximately $38 \%$ of the total primary production during times of peak abundance, and were important in phosphorus uptake. Cyanobacteria observed in the food vacuoles of heterotrophic microflagellates and in the guts of rotifers suggest that these organisms may be important consumers of this prokaryote population.

Chroococcoid cyanobacteria $(0.5-2.0 \mu \mathrm{m})$ are photosynthetic, prokaryotic microorganisms that have only recently been shown to be an important component of oceanic plankton communities $(1,2,3)$. They were overlooked in earlier studies because the conventional Utermöhl settling technique for counting phytoplankton (4) is inappropriate for such small cells. Single cells settle too slowly and are often indistinguishable from the more numerous heterotrophic bacteria. Epifluorescence microscopical techniques used for counting bacteria also overlooked these phototrophs, because they use stains which do not differentiate cyanobacteria from bacteria. Cyanobacteria can contribute significantly to total primary production in the open ocean $(5,6)$, and thus may constitute a significant source of organic carbon for organisms 
capable of grazing picoplankton-sized cells $(0.2-2.0 \mu \mathrm{m})$. There have been recent isolated reports of their presence in fresh water plankton $(7,8,9)$ but their relative importance has not been quantified. Even in marine systems $(1,2,3)$ there are no published reports which include a temperature depth-time relationship.

Observations in July 1981 revealed maximum densities of chroococcoid cyanobacteria of $7.46 \times 10^{5} \mathrm{ml}^{-1}$ in central Lake Ontario, indicating that these microorganisms could function importantly in the lake. Samples were collected from April to November, 1982 at 3 stations located on a transect across the lake as part of a major investigation of the degree and duration of phosphorus 11mitation of the plankton and changes in community composition during that period. Station 401 was near the north shore $\left(43^{\circ} 35^{\prime} 39^{\prime \prime} \mathrm{N}\right.$ $\left.78^{\circ} 15^{\prime} 34^{\prime \prime} \mathrm{W}\right)$, station 403 was near the mid lake region $\left(43^{\circ} 35^{\prime} 35^{\prime \prime} \mathrm{N}\right.$ $\left.78^{\circ} 13^{\prime} 55^{\prime \prime} \mathrm{W}\right)$ and station 405 near the south shore $\left(43^{\circ} 23^{\prime} 54^{\prime \prime N}\right.$ $\left.78^{\circ} 12^{\prime} 11^{\prime \prime} \mathrm{W}\right)$. Water samples for vertical profiles were collected using Niskin bottles, and temperature was measured using an electronic bathythermograph. Water samples were preserved in glutaraldehyde $(1.0 \% \mathrm{~V} / \mathrm{V})$ buffered with 0.1 Ma-cacodylate at $\mathrm{pH}=7.0$.

Water samples were enumerated for bacteria, chroococcoid cyanobacteria, and phototrophic and heterotrophic nanoplankton (2-20 $\mu \mathrm{m}$ in diameter) by epifluorescence microscopy using a Zeiss Standard microscope equipped with a 50W or 100W mercury lamp. Bacteria were counted using the DAPI technique (10) with a final stain concentration of $1.0 \mu \mathrm{g} \mathrm{m} 1^{-1}$. A G365 exciter filter, an FT420 chromatic beam splitter, and an LP418 barrier filter were used for observing the bacteria. Chroococcoid cyanobacteria were counted on pre-stained Nuclepore filters (11) by autofluorescence using a BP450-490 exciter filter, an FT510 chromatic beam sp1itter and an LP520 barrier filter. Yellow autofluorescent picoplankton were enumerated as cyanobacteria. The 
yellow fluorescence is indicative of the phycobiliprotein phycoerythrin. This counting procedure may slightly underestimate the number of cyanobacteria by eliminating those cells not possessing phycoerythrin. However, during the study autofluorescent picoplankton was highly dominated by yellow-fluorescing cells, obviating more detailed procedures for counting cyanobacteria lacking phycoerythrin (12). Nanoplankton were visualized by filtering water onto 0.22 or $0.45 \mu \mathrm{m}$ pore size Millipore filters, drying at $60^{\circ} \mathrm{C}$ for 15 minutes, and then clearing with Cargille immersion ofl type A. Heterotrophic nanoplankton processed in this way fluoresced a dull green color. Phototrophic nanoplankton were distinguished from heterotrophs by the red autofluorescence of chlorophyll a. This method of enumerating nanoplankton gave results comparable to those obtained using fluorochrome stains to visualize heterotrophic cells (13).

Biomass estimates were calculated for the microbial populations from population density and biovolume measurements determined by microscopical observations. Bacteria were recorded as $\operatorname{cocci}(\overline{\mathrm{X}}=0.5 \mu \mathrm{m}$ in diameter) or rods $(\bar{X}=0.2 \times 0.7 \mu \mathrm{m})$ and biovolume for these cells was calculated as volume of a sphere and volume of a cylinder, respectively. Biovolume of cyanobacteria $(\overline{\mathrm{X}}=1.0 \mu \mathrm{m}$ in diameter), and phototrophic and heterotrophic nanoplankton ( $\bar{X}=3.5 \mu \mathrm{m}$ in diameter) were calculated as volume of a sphere. Biovolume for all populations was converted to wet weight assuming a specific gravity of 1.0 .

The chroococcoid cyanobacteria present in Lake Ontario were dominated by spherical cells ranging in size from 0.7 to $1.3 \mu \mathrm{m}$ in diameter (Fig. $1 \mathrm{~A}$ ), and were often present in irregular clumps or in tetrads. Two examples of vertical profiles of cyanobacterial density are given in Fig. 1B for Station 403 at a time when the water was isothermal (April), and at a time when the water was thermally stratified (August). The corresponding temperature 
profiles are given in Fig. 1C. High densities of chroococcoid cyanobacteria $\left(>10^{5} \mathrm{ml}^{-1}\right)$ were observed in the surface water during the period of thermal stratification. Below the thermocline, and during the period of cold isothermal water, cell counts were substantially lower $\left(<10^{3} \mathrm{ml}^{-1}\right)$.

The seasonal distribution of chroococcoid cyanobacteria at $5 \mathrm{~m}$ in central Lake Ontario showed a strong correlation with temperature (Fig. D). Cyanobacterial numbers increased rapidly beginning in late June and maximum abundance coincided with maximum water temperature $\left(22^{\circ} \mathrm{C}\right)$ during August. The magnitude of the seasonal increase in cyanobacteria at Station 403 (approximately 3 to 4 orders of magnitude) is comparable to the difference of cyanobacterial abundance above and below the thermocline during August. At Station 403, cyanobacterial numbers increased logarithmically from early June to near the end of July with an apparent net doubling time of 8 days. Obviously, this does not represent a true doubling time as we do not know the impact of grazing and other losses to the population. Nevertheless, it provides a minimum growth rate during this warming period $\left(4-17^{\circ} \mathrm{C}\right)$. Cyanobacterial abundance from 0 to $15 \mathrm{~m}$ was positively correlated with temperature for all 3 stations in Lake Ontario throughout the study period (Fig. 1E). This correlation has also been noted for chroococcoid cyanobacteria in temperate marine waters and agrees with laboratory culture work (J.B. Waterbury, pers. comm.).

The numerical and biomass contributions of chroococcoid cyanobacteria to the total pico- and nanoplankton are given in Table 1 for $5 \mathrm{~m}$ water at Station 403 in April and August. Bacteria were numerically dominant in both samples. Cyanobacteria were second in abundance during August, but were less abundant than the nanoplankton in April. The biomass of the cyanobacteria at $5 \mathrm{~m}$ in August was $32 \%$ of the total microbial plankton less than $20 \mu \mathrm{m}, 70 \%$ of the biomass of primary producers in this same size fraction, and $39 \%$ of the 
prokaryote biomass. The biomass of cyanobacteria was insignificant in April. When summed over the whole water column, cyanobacterial biomass in August was $15 \%$ of the total microbial biomass less than $20 \mu \mathrm{m}, 30 \%$ of the primary producers, and $26 \%$ of the prokaryote biomass. The reduced importance of the cyanobacteria when summed over the entire water column is due to their restriction to water above the thermocline. While the density of the other microbial populations also decreased with depth, the magnitude of the decrease was greater for the cyanobacteria.

Phytoplankton studies in Lake Ontario have not previously reported chroococcoid cyanobacteria $(14,15)$. Size fractionation using $5.0,1.0$ and 0.2 $\mu \mathrm{m}$ pore size Nuclepore polycarbonate filters (16) showed that $54.3 \%$ of the chroococcoid cyanobacteria was in the range of $1.0-5.0 \mu \mathrm{m}$ but $30.3 \%$ passed the $1.0 \mu \mathrm{m}$ filter (Table 1). Nearly all of the phototrophic nanoplankton were in

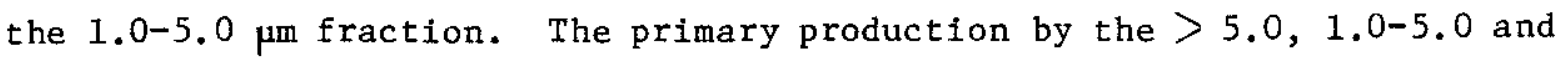
$<1.0 \mu \mathrm{m}$ fractions was $23.7,64.7$ and $11.6 \%$ of the total, respectively. The cyanobacteria were the only photosynthetic organisms in the $<1.0 \mu \mathrm{m}$ fraction. If these cells are indicative of the activity of all chroococcoid cyanobacteria, then the predicted rate for all the chroococcoid cyanobacteria would be $38 \%$ of the total primary production.

The size distribution for uptake of radioactive phosphate at ambient and phosphate enriched conditions has been discussed in more detail by Lean (16). The uptake of phosphate by the $>5.0,1.0-5.0$ and $<1.0 \mu$ fractions was 2,54 and $44 \%$ at ambient phosphate concentrations but shifted to 16,69 and $16 \%$, respectively, with added phosphate. These results suggest that the chroococcoid cyanobacteria were important in phosphorus metabolism at that time. However, unlike that for ${ }^{14} \mathrm{C}$ primary productivity, it was not possible to estimate uptake of phosphate attributable to cyanobacteria alone because the bacterial population in the $<1.0 \mu \mathrm{m}$ fraction might also be 
responsible for phosphate uptake. Lehman and Sandgren (17) noted a marked capability of phosphate uptake by picoplankton (bacteria and cyanobacteria) in a Michigan lake. These results, together with recent studies documenting the occurrence of chroococcold cyanobacteria in freshwater $(7,8,9)$, indicate that these microorganisms may contribute significantly to primary productivity and nutrient cycling in freshwater ecosystems. A reexamination is warranted to determine the ubiquitousness of these microorganisms in freshwater.

The biomass of chroococcold cyanobacteria observed in this study suggests that they may be an important food source for picoplankton consumers. They were commonly observed in the food vacuoles of heterotrophic microflagellates from the epilimnion. Up to $15 \%$ of the population of microflagellates contained ingested cyanobacteria when cyanobacterial densities exceeded $10^{5}$ $\mathrm{ml}^{-1}$. Ingestion rates by microflagellates were not determined in this study, but high population densities of heterotrophic nanoplankton (Table 1) suggest that these microorganisms may be important consumers of cyanobacteria. Chroococcoid cyanobacteria have been shown to support the growth of microflagellates under laboratory conditions (Caron, unpubl.).

Rotifers (e.g. Keratella cochlieris) were also observed with ingested cyanobacteria in this study, indicating that these zooplankton may also be able to use these prokaryotes as food. On the other hand, intact cyanobacteria were found in copepod fecal pellets, confirming the observation that they may be resistant to digestion by these zooplankton $(18,19)$. More work is needed to determine the extent of zooplankton grazing on chroococcoid cyanobacteria. Certainly, if they are as abundant in other lakes as they are in Lake Ontario, these prokaryotes play an important role in the food webs of freshwater plankton communities. 


\section{REFERENCES}

1. Johnson, P.W \& Sieburth, J.McN. Limmol. Oceanogr. 24, 928-935 (1979).

2. Waterbury, J.B., Watson, S.W., Guillard, R.R.L. \& Brand, L.E. Nature 277, 293-294 (1979).

3. Krempin, D.W. \& Sullivan, C.W. Can. J. Microbiol. 27, 1341-1344 (1981).

4. Utermoh1, H. Mitt. Int. Ver. Limnol. 9, 1-38 (1958).

5. Platt, T., Rao, D.V.S. \& Irwin, B. Nature 301, 702-704 (1983).

6. Li, W.K.W., Rao, D.V.S., Harrison, W.G., Smith, J.C., Cullen, J.J., Irwin, B. \& Platt, T. Science 219, 292-295 (1983).

7. Craig, S.R. Paper presented at the American Society of Limnology and Oceanography Annual Meeting, Raleigh, N.C., June, 1982.

8. Cronberg, G. \& Weibull, C. Arch. Hydrobiol. Suppl. 60, 101-110 (1981).

9. Chang, V.T-P. Schweiz. Z. Hydrol. 42, 247-254 (1980).

10. Porter, K.G. \& Feig, Y.S. Limnol. Oceanogr. 25, 943-948 (1980).

11. Hobbie, J.E., Daley, R.J. \& Jaspar, S. App1. Environ. Microbiol. 33, $1225-1228$ ( 1977$)$.

12. Campbe1I, L., Carpenter, E.J. \& Iacono, V.J. App1. Environ. Microbiol. $46,553-559$ (1983).

13. Davis, P.G. \& Sieburth, J.McN. Ann. Inst. Oceanogr. 58(S), 249-259 (1982). The use of fluo rochrome stains to visualize heterotrophic nanoplankton was avoided in this study because the large amount of suspended detritus (whtch also absorbed the fluorochrome) made observation of nanoplankton difficult. Drying at $60^{\circ} \mathrm{C}$ for 15 minutes did not adversely affect the intensity of the red chlorophyll autofluo rescence.

14. Munawar, M. \& Nauwerck, A. Proc. 14th Conf. Great Lakes Res. 69-78 (1971).

15. Munawar, M., Stadelmann, P. \& Munawar, I.F. Proc. 14th Conf. Great Lakes 
Res. 629-652 (1974).

16. Lean, D.R.S. Mitt. Int. Ver. Theor. Angew. Limnol. (1984).

17. Lehman, J.T. \& Sandgren, C.D. Limnol. Oceanogr. 27, 828-838 (1982).

18. Johnson, P.W., Xu, H. \& Sieburth, J.McN. Ann. Inst. Oceanogr. 58(s), 297-308 (1982).

19. Silver, M.W. \& Alldredge, A.L. J. Mar. Res. 39, 501-530 (1981).

20. The authors would like to thank J.B. Waterbury for helpful comments on the manuscript. This research was partially supported by the Joint

- Program in Biological Oceanography of the Massachusetts Institute for Technology and Woods Hole Oceanographic Institution (for D.A.C.). Woods Hole Oceanographic Institution Contribution no. 0000. 
Table 1. Population density $( \pm 1$ standard deviation), biomass and percent of the population observed in size-fractionated samples for microorganisms less than $20 \mu \mathrm{m}$ in size. The samples were collected from $5 \mathrm{~m}$ at Station 403 (located centra11y in Lake Ontario) on 28 Apri1 1982 and 24 August 1982 . Numbers in brackets are the percent of the total biomass.

\begin{tabular}{|c|c|c|c|c|c|}
\hline DATE & PARAMETER & $\begin{array}{l}\text { CHROOCOCCOID } \\
\text { CYANOBACTERTA } \\
\end{array}$ & BACTER IA & $\begin{array}{l}\text { PHOTOTROPHIC } \\
\text { NANOPLANKTON }\end{array}$ & $\begin{array}{l}\text { HETEROTROPHIC } \\
\text { NANOPLANKTON }\end{array}$ \\
\hline \multirow{2}{*}{28 Apri1 1982} & $\begin{array}{l}\text { Density } \\
\left.\text { (No. } m 1^{-1}\right)\end{array}$ & $\begin{aligned} & 4.95 \times 10^{1} \\
+ & 8.58\end{aligned}$ & $\begin{aligned} & 1.37 \times 10^{6} \\
+ & 0.35\end{aligned}$ & $\begin{aligned} & 2.66 \times 10^{3} \\
+ & 0.10\end{aligned}$ & $\begin{aligned} & 9.41 \times 10^{2} \\
+ & 0.45\end{aligned}$ \\
\hline & $\begin{array}{l}\text { Biomass } \\
\left(\mu \mathrm{g} \text { wet wgt } \mathrm{ml}^{-1}\right)\end{array}$ & $\begin{array}{c}0.03 \\
(0.02)\end{array}$ & $\begin{array}{c}98 \\
(54 \cdot 7)\end{array}$ & $\begin{array}{c}60 \\
(33.5)\end{array}$ & $\begin{array}{c}21 \\
(11.7)\end{array}$ \\
\hline \multirow{5}{*}{24 August 1982} & $\begin{array}{l}\text { Density } \\
\left(\text { No. } \mathrm{ml}^{-1}\right)\end{array}$ & $\begin{aligned} & 4.25 \times 10^{5} \\
+ & 0.56\end{aligned}$ & $\begin{aligned} & 4.67 \times 10^{6} \\
\pm & 0.82\end{aligned}$ & $\begin{aligned} & 4.16 \times 10^{3} \\
+ & 0.39\end{aligned}$ & $\begin{array}{l}1.24 \times 10^{3} \\
+0.24\end{array}$ \\
\hline & $\begin{array}{l}\text { Biomass } \\
\left(\mu g \text { wet wgt } 1^{-1}\right)\end{array}$ & $\begin{array}{l}223 \\
(32.0)\end{array}$ & $\begin{array}{l}352 \\
(50.5)\end{array}$ & $\begin{array}{c}94 \\
(13.5)\end{array}$ & $\begin{array}{l}28 \\
(4 \cdot 0)\end{array}$ \\
\hline & $\begin{array}{l}\% \text { in the }>5 \mu m \\
\text { Size Fraction }\end{array}$ & $15 \cdot 4$ & 0 & 0 & $\mathrm{~N} / \mathrm{D}$ \\
\hline & $\begin{array}{l}\% \text { in the } 1.0-5.0 \\
\mu \mathrm{m} \text { Size Fraction }\end{array}$ & $54 \cdot 3$ & 0 & 99.1 & $\mathrm{~N} / \mathrm{D}$ \\
\hline & $\begin{array}{l}\% \text { in the }<1.0 \mu \mathrm{m} \\
\text { Size Fraction }\end{array}$ & $30 \cdot 3$ & 100 & 0.9 & $\mathrm{~N} / \mathrm{D}$ \\
\hline
\end{tabular}


Figure 1. A.) Photomicrograph of the autofluorescence of chroococcoid cyanobacteria in Lake Ontario on 24 August 1982. Scale bar $=1.0 \mu \mathrm{m}$. B.) Vertical profiles of chroococcoid cyanobacterial density in central Lake Ontario on 28 April 1982 and 24 August 1982. C.) Temperature profiles at the time of sampling in (B). D.) Seasonal distribution of chroococcoid cyanobacteria and temperature at $5 \mathrm{~m}$ in central Lake Ontario during 1982. The drop in water temperature in late August is presumably a result of advective forces. E.) Correlation of cyanobacterial density with temperature in surface waters at 3 stations in Lake Ontario in 1982. 


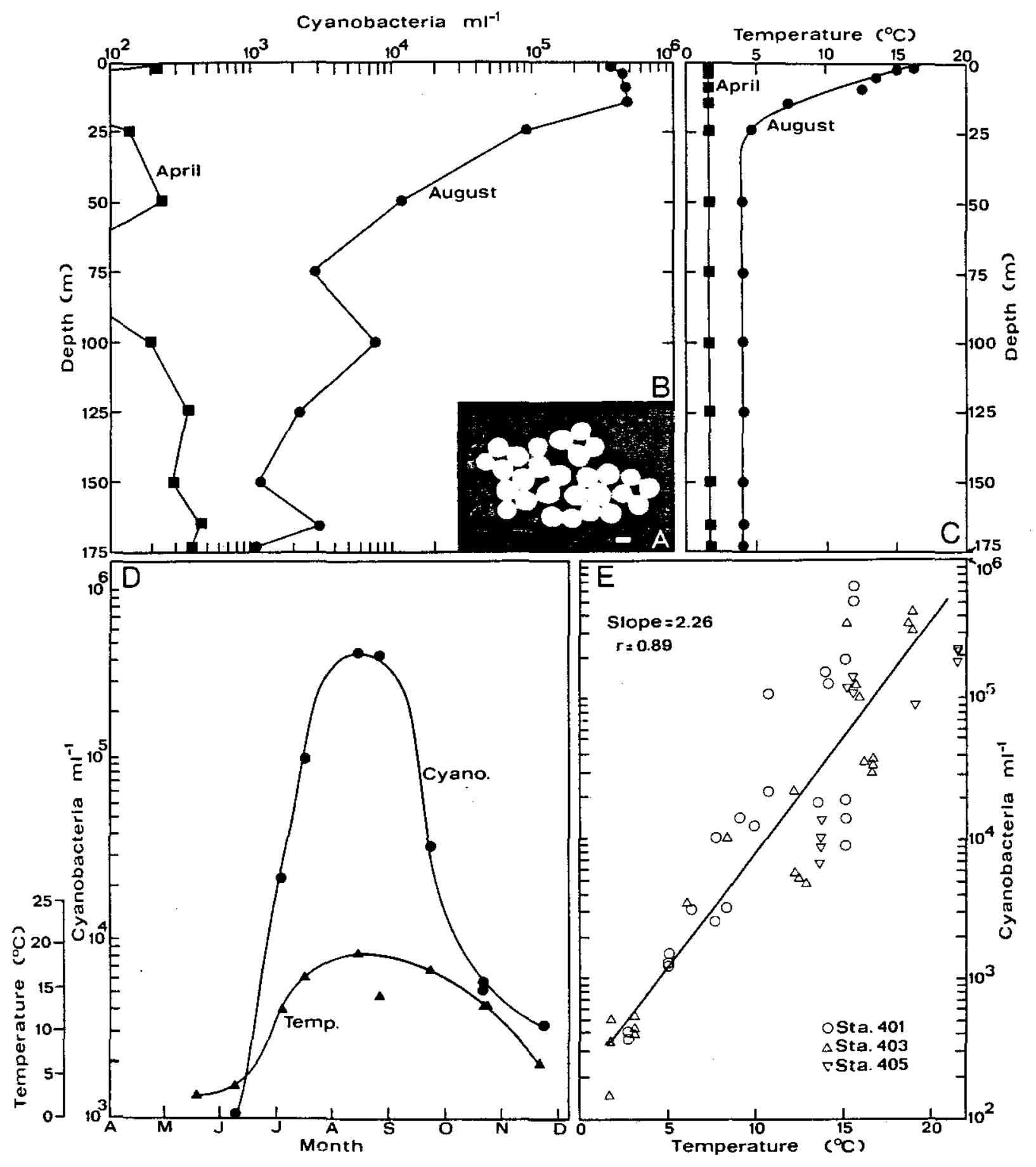




\author{
APPENDIX VI \\ EPIFLUORESCENCE COUNTS OF HPICO, PPICO, HNANO AND PNANO \\ IN WATER SAMPLES FROM THE NORTH ATLANTIC \\ AND IAKE ONTARIO
}


Epifluorescence counts of Hpico, Ppico, Pnano, Hnano in water samples from the five cruises in the North Atlantic and three cruises in Lake Ontario. Counting procedures are given in Appendix I. All densities are expressed as the number of organisms $\mathrm{ml}^{-1}$. Counting errors (given below the density estimate) are \pm 1 standard deviation. 
Table AVI.1. Data from the R/V Columbus Iselin (Cruise CI83-01).

\begin{tabular}{|c|c|c|c|c|c|c|}
\hline DATE & LOCATION & $\begin{array}{l}\text { DEPTH } \\
(\mathrm{M}) \\
\end{array}$ & $\begin{array}{c}\text { HPICO } \\
(\mathrm{No} . / \mathrm{m} 1) \\
\end{array}$ & $\begin{array}{c}\text { PPICO } \\
(\text { No./m1) }\end{array}$ & $\begin{array}{c}\text { PNANO } \\
(\text { No./m1 }) \\
\end{array}$ & $\begin{array}{l}\text { HNANO } \\
(\text { No./m1) }\end{array}$ \\
\hline \multirow[t]{7}{*}{$2 / 22 / 83$} & $\begin{array}{l}29^{\circ} 03^{\prime} \mathrm{N} \\
76^{\circ} 04^{\prime} \mathrm{W}\end{array}$ & 1 & $\begin{array}{l}4.50 \times 10^{5} \\
\pm 0.41\end{array}$ & $\begin{array}{l}2.47 \times 10^{4} \\
+0.29\end{array}$ & $\begin{array}{l}9.31 \times 10^{2} \\
\pm 0.31\end{array}$ & $\begin{array}{l}8.68 \times 10^{2} \\
+0.19\end{array}$ \\
\hline & & 10 & $\begin{array}{l}4.95 \times 10^{5} \\
\pm 0.34\end{array}$ & $\begin{array}{l}2.37 \times 10^{4} \\
\pm 0.25\end{array}$ & $\begin{array}{l}8.57 \times 10^{2} \\
\pm 0.60\end{array}$ & $\begin{array}{l}8.09 \times 10^{2} \\
\pm 0.79\end{array}$ \\
\hline & & 30 & $\begin{array}{l}4.27 \times 10^{5} \\
\pm 0.49\end{array}$ & $\begin{array}{l}1.94 \times 10^{4} \\
\pm 0.31\end{array}$ & $\begin{array}{l}8.13 \times 10^{2} \\
+0.88\end{array}$ & $\begin{array}{l}9.09 \times 10^{2} \\
\pm 0.52\end{array}$ \\
\hline & & 50 & $\begin{array}{l}3.83 \times 10^{5} \\
\pm 0.22\end{array}$ & $\begin{array}{l}2.99 \times 10^{4} \\
\pm 0.41\end{array}$ & $\begin{array}{l}8.80 \times 10^{2} \\
\pm 0.25\end{array}$ & $\begin{array}{c}3.97 \times 10^{2} \\
+0.49\end{array}$ \\
\hline & & 80 & $\begin{array}{l}4.23 \times 10^{5} \\
\pm 0.27\end{array}$ & $\begin{array}{l}1.20 \times 10^{4} \\
\pm 0.18\end{array}$ & $\begin{array}{l}9.06 \times 10^{2} \\
\pm 0.44\end{array}$ & $\begin{array}{l}4.53 \times 10^{2} \\
+0.49\end{array}$ \\
\hline & & 100 & $\begin{array}{l}2.77 \times 10^{5} \\
\pm 0.36\end{array}$ & $\begin{array}{l}1.00 \times 10^{4} \\
\pm 0.14\end{array}$ & $\begin{array}{l}4.87 \times 10^{2} \\
\pm 0.71\end{array}$ & $\begin{array}{l}2.37 \times 10^{2} \\
\pm 0.27\end{array}$ \\
\hline & & 500 & $\begin{array}{c}4.72 \times 10^{4} \\
\pm 0.90\end{array}$ & 4.90 & $\begin{array}{l}1.65 \times 10^{1} \\
\pm 1.51\end{array}$ & $\begin{array}{l}4.81 \times 10^{2} \\
+0.35\end{array}$ \\
\hline \multirow[t]{7}{*}{$3 / 7 / 83$} & $\begin{array}{l}33^{\circ} 10^{\prime} \mathrm{N} \\
76^{\circ} 40^{\prime} \mathrm{W}\end{array}$ & 1 & $\begin{array}{l}7.68 \times 10^{5} \\
\pm 0.64\end{array}$ & $\begin{array}{l}5.47 \times 10^{4} \\
+0.64\end{array}$ & $\begin{array}{l}8.39 \times 10^{2} \\
\pm 0.49\end{array}$ & $\begin{array}{l}2.71 \times 10^{2} \\
\pm 0.25\end{array}$ \\
\hline & & 10 & $\begin{array}{l}6.38 \times 10^{5} \\
\pm 0.43\end{array}$ & $\begin{array}{l}5.35 \times 10^{4} \\
\pm 0.67\end{array}$ & $\begin{array}{l}1.68 \times 10^{3} \\
\pm 0.15\end{array}$ & $\begin{array}{l}5.34 \times 10^{2} \\
\pm 0.64\end{array}$ \\
\hline & & 30 & $\begin{array}{l}8.48 \times 10^{5} \\
\pm 0.49\end{array}$ & $\begin{array}{l}4.04 \times 10^{4} \\
+0.26\end{array}$ & $\begin{array}{l}4.97 \times 10^{2} \\
+0.66\end{array}$ & $\begin{array}{l}3.08 \times 10^{2} \\
\pm 0.37\end{array}$ \\
\hline & & 50 & $\begin{array}{l}8.90 \times 10^{5} \\
\pm 0.92\end{array}$ & $\begin{array}{l}2.96 \times 10^{4} \\
\pm 0.19\end{array}$ & $\begin{array}{l}7.61 \times 10^{2} \\
+0.49\end{array}$ & $\begin{array}{l}3.38 \times 10^{2} \\
\pm 0.31\end{array}$ \\
\hline & & 80 & $\begin{array}{l}5.06 \times 10^{5} \\
\pm 0.67\end{array}$ & $\begin{array}{l}5.59 \times 10^{3} \\
+0.62\end{array}$ & $\begin{array}{l}5.27 \times 10^{2} \\
\pm 0.31\end{array}$ & $\begin{array}{c}4.12 \times 10^{2} \\
\pm 0.33\end{array}$ \\
\hline & & 100 & $\begin{array}{l}5.20 \times 10^{5} \\
\pm 0.51\end{array}$ & $\begin{array}{l}1.33 \times 10^{3} \\
\pm 0.23\end{array}$ & $\begin{array}{l}1.41 \times 10^{2} \\
\pm 0.23\end{array}$ & $\begin{array}{l}1.96 \times 10^{2} \\
\pm 0.17\end{array}$ \\
\hline & & 500 & $\begin{array}{l}4.58 \times 10^{4} \\
\pm 0.52\end{array}$ & $\begin{array}{l}4.09 \times 10^{1} \\
+2.18\end{array}$ & $\begin{array}{l}5.93 \\
+8.37\end{array}$ & $\begin{array}{c}8.60 \times 10^{1} \\
\pm 2.40\end{array}$ \\
\hline
\end{tabular}


Table AVI.2. Data from the R/V Oceanus (Cruise 115).

\begin{tabular}{|c|c|c|c|c|c|c|}
\hline DATE & LOCATION & $\begin{array}{c}\text { DEPTH } \\
(\mathrm{M}) \\
\end{array}$ & $\begin{array}{c}\text { HPICO } \\
(\text { No./m1) }\end{array}$ & $\begin{array}{c}\text { PPICO } \\
(\text { No./m1) }\end{array}$ & $\begin{array}{l}\text { PNANO } \\
(\text { No./m1) }\end{array}$ & $\begin{array}{l}\text { HNANO } \\
(\mathrm{No} / \mathrm{ml}) \\
\end{array}$ \\
\hline \multirow[t]{6}{*}{$2 / 20 / 82$} & $\begin{array}{l}29^{\circ} 59^{\prime} \mathrm{N} \\
76^{\circ} 01^{\prime} \mathrm{W}\end{array}$ & 1 & $\begin{array}{l}9.47 \times 10^{5} \\
\pm 1.11\end{array}$ & $\begin{array}{c}2.89 \times 10^{4} \\
\pm 0.44\end{array}$ & $\begin{array}{l}6.61 \times 10^{2} \\
\pm 0.55\end{array}$ & $\begin{array}{l}5.97 \times 10^{2} \\
+0.79\end{array}$ \\
\hline & & 10 & $\begin{array}{l}8.15 \times 10^{5} \\
\pm 0.85\end{array}$ & $\begin{array}{l}3.52 \times 10^{4} \\
\pm 0.53\end{array}$ & $\begin{array}{l}6.01 \times 10^{2} \\
\pm 0.30\end{array}$ & $\begin{array}{l}6.21 \times 10^{2} \\
\pm 0.65\end{array}$ \\
\hline & & 20 & $\begin{array}{l}8.55 \times 10^{5} \\
+0.79\end{array}$ & $\begin{array}{l}3.16 \times 10^{4} \\
+0.28\end{array}$ & $\begin{array}{l}6.09 \times 10^{2} \\
\pm 0.38\end{array}$ & $\begin{array}{c}5.66 \times 10^{2} \\
\pm 0.48\end{array}$ \\
\hline & & 40 & $\begin{array}{c}8.48 \times 10^{5} \\
\pm 0.84\end{array}$ & $\begin{array}{l}3.77 \times 10^{4} \\
\pm 0.46\end{array}$ & $\begin{array}{l}5.46 \times 10^{2} \\
\pm 0.24\end{array}$ & $\begin{array}{c}4.83 \times 10^{2} \\
+0.18\end{array}$ \\
\hline & & 100 & $\begin{array}{l}5.05 \times 10^{5} \\
+0.48\end{array}$ & $\begin{array}{l}1.57 \times 10^{3} \\
\pm 0.15\end{array}$ & $\begin{array}{l}4.31 \times 10^{2} \\
\pm 0.60\end{array}$ & $\begin{array}{l}4.31 \times 10^{2} \\
+0.77\end{array}$ \\
\hline & & 500 & $\begin{array}{c}1.47 \times 10^{5} \\
\pm 0.26\end{array}$ & $\begin{array}{r}7.95 \\
+13.64\end{array}$ & $\begin{array}{r}1.96 \\
+3.44\end{array}$ & $\begin{array}{l}7.71 \times 10^{1} \\
+1.03\end{array}$ \\
\hline \multirow[t]{3}{*}{$2 / 27 / 82$} & $\begin{array}{l}30^{\circ} 59^{\prime} \mathrm{N} \\
80^{\circ} 38^{\prime} \mathrm{W}\end{array}$ & 1 & $\begin{array}{l}1.75 \times 10^{6} \\
\pm 0.15\end{array}$ & $\begin{array}{c}2.89 \times 10^{4} \\
\pm 0.54\end{array}$ & $\begin{array}{c}1.83 \times 10^{3} \\
+0.27\end{array}$ & $\begin{array}{l}1.79 \times 10^{3} \\
+0.05\end{array}$ \\
\hline & & 10 & $\begin{array}{l}2.00 \times 10^{6} \\
\pm 0.22\end{array}$ & $\begin{array}{l}2.51 \times 10^{4} \\
+0.23\end{array}$ & $\begin{array}{l}1.92 \times 10^{3} \\
\pm 0.14\end{array}$ & $\begin{array}{l}1.85 \times 10^{3} \\
\pm 0.09\end{array}$ \\
\hline & & 20 & $\begin{array}{l}1.91 \times 10^{6} \\
\pm 0.26\end{array}$ & $\begin{array}{c}1.87 \times 10^{4} \\
\pm 0.27\end{array}$ & $\begin{array}{l}2.10 \times 10^{3} \\
\pm 0.06\end{array}$ & $\begin{array}{l}1.95 \times 10^{3} \\
+0.15\end{array}$ \\
\hline \multirow[t]{5}{*}{$2 / 29 / 82$} & $\begin{array}{l}30^{\circ} 56^{\prime} \mathrm{N} \\
79^{\circ} 40^{\prime} \mathrm{W}\end{array}$ & 1 & $\begin{array}{c}1.33 \times 10^{6} \\
\pm 0.13\end{array}$ & $\begin{array}{c}1.42 \times 10^{4} \\
+0.22\end{array}$ & $\begin{array}{l}1.38 \times 10^{3} \\
\pm 0.10\end{array}$ & $\begin{array}{c}9.80 \times 10^{2} \\
\pm 1.03\end{array}$ \\
\hline & & 10 & $\begin{array}{c}1.26 \times 10^{6} \\
\pm 0.63\end{array}$ & $\begin{array}{c}1.37 \times 10^{4} \\
\pm 0.16\end{array}$ & $\begin{array}{l}1.49 \times 10^{3} \\
\pm 0.14\end{array}$ & $\begin{array}{c}9.00 \times 10^{2} \\
\pm 0.75\end{array}$ \\
\hline & & 20 & $\begin{array}{c}1.49 \times 10^{6} \\
\pm 0.20\end{array}$ & $\begin{array}{c}1.44 \times 10^{4} \\
\pm 0.15\end{array}$ & $\begin{array}{c}1.47 \times 10^{3} \\
+0.06\end{array}$ & $\begin{array}{l}9.11 \times 10^{2} \\
\pm 1.12\end{array}$ \\
\hline & & 50 & $\begin{array}{c}1.42 \times 10^{6} \\
\pm 0.10\end{array}$ & $\begin{array}{l}1.78 \times 10^{4} \\
+0.24\end{array}$ & $\begin{array}{c}2.04 \times 10^{3} \\
+0.07\end{array}$ & $\begin{array}{c}1.15 \times 10^{3} \\
\pm 0.18\end{array}$ \\
\hline & & 500 & $\begin{array}{c}6.19 \times 10^{4} \\
+0.32\end{array}$ & $\begin{array}{c}4.45 \times 10^{1} \\
+2.97\end{array}$ & 2 & $\begin{array}{c}5.74 \times 10^{1} \\
+2.74\end{array}$ \\
\hline
\end{tabular}


Table AVI.3. Data from R/V Knorr (Cruise KN94).

\begin{tabular}{|c|c|c|c|c|c|c|}
\hline DATE & LOCATION & $\begin{array}{l}\text { DEPTH } \\
(\mathrm{M}) \\
\end{array}$ & $\begin{array}{c}\text { HPICO } \\
(\text { No./m1) }\end{array}$ & $\begin{array}{c}\text { PPICO } \\
\text { (No./m1) }\end{array}$ & $\begin{array}{l}\text { PNANO } \\
(\text { No./m1) }\end{array}$ & $\begin{array}{l}\text { HNANO } \\
(\text { No. } / \mathrm{m} 1)\end{array}$ \\
\hline \multirow[t]{7}{*}{$5 / 19 / 82$} & $\begin{array}{l}39^{\circ} 45^{\prime} \mathrm{N} \\
72^{\circ} 00^{\prime} \mathrm{W}\end{array}$ & 1 & $\begin{array}{c}1.50 \times 10^{6} \\
+0.49\end{array}$ & $\begin{array}{c}1.00 \times 10^{5} \\
\pm 0.19\end{array}$ & $\begin{array}{c}3.15 \times 10^{3} \\
+0.08\end{array}$ & $\begin{array}{c}3.08 \times 10^{3} \\
\pm 0.26\end{array}$ \\
\hline & & 10 & $\begin{array}{l}1.59 \times 10^{6} \\
\pm 0.25\end{array}$ & $\begin{array}{l}9.61 \times 10^{4} \\
\pm 0.90\end{array}$ & $\begin{array}{l}2.94 \times 10^{3} \\
\pm 0.26\end{array}$ & $\begin{array}{l}3.21 \times 10^{3} \\
\pm 0.17\end{array}$ \\
\hline & & 30 & $\begin{array}{l}7.99 \times 10^{5} \\
\pm 1.23\end{array}$ & $\begin{array}{l}3.92 \times 10^{4} \\
\pm 0.44\end{array}$ & $\begin{array}{l}2.12 \times 10^{3} \\
\pm 0.21\end{array}$ & $\begin{array}{l}1.55 \times 10^{3} \\
\pm 0.09\end{array}$ \\
\hline & & 60 & $\begin{array}{l}3.84 \times 10^{5} \\
\pm 0.52\end{array}$ & $\begin{array}{l}4.08 \times 10^{3} \\
\pm 0.49\end{array}$ & $\begin{array}{l}1.30 \times 10^{3} \\
\pm 0.06\end{array}$ & $\begin{array}{l}1.44 \times 10^{3} \\
\pm 0.06\end{array}$ \\
\hline & & 100 & $\begin{array}{c}2.67 \times 10^{5} \\
+0.38\end{array}$ & $\begin{array}{l}4.51 \times 10^{2} \\
\pm 0.21\end{array}$ & $\begin{array}{l}3.66 \times 10^{2} \\
+0.75\end{array}$ & $\begin{array}{l}8.91 \times 10^{2} \\
\pm 0.13\end{array}$ \\
\hline & & 200 & $\begin{array}{c}1.86 \times 10^{5} \\
\pm 0.39\end{array}$ & $\begin{array}{l}4.39 \times 10^{2} \\
\pm 0.24\end{array}$ & $\begin{array}{l}3.24 \times 10^{2} \\
+0.65\end{array}$ & $\begin{array}{l}5.46 \times 10^{2} \\
\pm 0.52\end{array}$ \\
\hline & & 300 & $\begin{array}{l}1.38 \times 10^{5} \\
\pm 0.68\end{array}$ & $\begin{array}{l}2.69 \times 10^{2} \\
+0.18\end{array}$ & $\begin{array}{l}2.25 \times 10^{2} \\
\pm 0.93\end{array}$ & $\begin{array}{l}5.62 \times 10^{2} \\
+0.48\end{array}$ \\
\hline \multirow[t]{8}{*}{$5 / 23 / 82$} & $\begin{array}{l}33^{\circ} 59^{\prime} \mathrm{N} \\
73^{\circ} 11^{\prime} \mathrm{W}\end{array}$ & 1 & $\begin{array}{l}2.66 \times 10^{5} \\
\pm 0.74\end{array}$ & $\begin{array}{l}1.46 \times 10^{4} \\
\pm 0.15\end{array}$ & $\begin{array}{l}6.63 \times 10^{2} \\
\pm 1.11\end{array}$ & $\begin{array}{l}1.12 \times 10^{3} \\
\pm 0.16\end{array}$ \\
\hline & & 10 & $\begin{array}{l}2.92 \times 10^{5} \\
\pm 0.71\end{array}$ & $\begin{array}{c}1.28 \times 10^{4} \\
+0.12\end{array}$ & $\begin{array}{l}4.40 \times 10^{2} \\
\pm 0.70\end{array}$ & $\begin{array}{l}1.11 \times 10^{3} \\
\pm 0.17\end{array}$ \\
\hline & & 30 & $\begin{array}{c}2.63 \times 10^{5} \\
+0.67\end{array}$ & $\begin{array}{c}1.47 \times 10^{4} \\
+0.15\end{array}$ & $\begin{array}{l}4.16 \times 10^{2} \\
\pm 1.04\end{array}$ & $\begin{array}{l}9.99 \times 10^{2} \\
+0.34\end{array}$ \\
\hline & & 50 & $\begin{array}{l}3.47 \times 10^{5} \\
\pm 0.49\end{array}$ & $\begin{array}{l}3.10 \times 10^{4} \\
\pm 0.25\end{array}$ & $\begin{array}{l}3.22 \times 10^{2} \\
\pm 0.48\end{array}$ & $\begin{array}{l}7.97 \times 10^{2} \\
\pm 1.52\end{array}$ \\
\hline & & 75 & $\begin{array}{l}3.38 \times 10^{5} \\
+0.56\end{array}$ & $\begin{array}{c}3.89 \times 10^{4} \\
\pm 0.58\end{array}$ & $\begin{array}{l}4.95 \times 10^{2} \\
\pm 0.84\end{array}$ & $\begin{array}{l}4.75 \times 10^{2} \\
\pm 1.03\end{array}$ \\
\hline & & 100 & $\begin{array}{l}1.88 \times 10^{5} \\
\pm 0.26\end{array}$ & $\begin{array}{l}7.75 \times 10^{3} \\
\pm 1.73\end{array}$ & $\begin{array}{c}2.81 \times 10^{2} \\
+0.25\end{array}$ & $\begin{array}{l}1.15 \times 10^{2} \\
\pm 0.45\end{array}$ \\
\hline & & 200 & $\begin{array}{l}1.42 \times 10^{5} \\
+0.25\end{array}$ & $\begin{array}{c}2.48 \times 10^{1} \\
+3.09\end{array}$ & $\begin{array}{l}3.96 \times 10^{2} \\
\pm 6.82\end{array}$ & $\begin{array}{c}1.27 \times 10^{2} \\
+0.28\end{array}$ \\
\hline & & 500 & $\begin{array}{l}4.26 \times 10^{4} \\
+2.08\end{array}$ & $\begin{array}{r}1.96 \\
+3.44\end{array}$ & 2 & $\begin{array}{c}9.30 \times 10^{1} \\
\pm 2.98\end{array}$ \\
\hline
\end{tabular}


Table AVI.3 (ContInued).

\begin{tabular}{|c|c|c|c|c|c|c|}
\hline DATE & LOCATION & $\begin{array}{c}\text { DEPTH } \\
(\mathrm{M}) \\
\end{array}$ & $\begin{array}{c}\text { HPICO } \\
(\text { No. } / \mathrm{m} 1) \\
\end{array}$ & $\begin{array}{c}\text { PPICO } \\
(\text { No./m1) }\end{array}$ & $\begin{array}{l}\text { PNANO } \\
\text { (No./m1) }\end{array}$ & $\begin{array}{l}\text { HNANO } \\
(\text { No. } / \mathrm{m} 1)\end{array}$ \\
\hline \multirow[t]{6}{*}{$5 / 28 / 82$} & $\begin{array}{l}33^{\circ} 38^{\prime} \mathrm{N} \\
76^{\circ} 14^{\prime} \mathrm{W}\end{array}$ & 1 & $\begin{array}{l}4.99 \times 10^{5} \\
\pm 1.07\end{array}$ & $\begin{array}{l}2.97 \times 10^{1} \\
\pm 2.97\end{array}$ & $\begin{array}{c}4.45 \times 10^{1} \\
\pm 3.00\end{array}$ & $\begin{array}{l}5.84 \times 10^{2} \\
\pm 0.56\end{array}$ \\
\hline & & 8 & $\begin{array}{c}1.74 \times 10^{5} \\
\pm 0.43\end{array}$ & $\begin{array}{c}4.30 \times 10^{2} \\
\pm 1.12\end{array}$ & $\begin{array}{c}1.24 \times 10^{2} \\
\pm 0.17\end{array}$ & $\begin{array}{c}6.73 \times 10^{2} \\
\pm 0.60\end{array}$ \\
\hline & & 25 & $\begin{array}{c}2.38 \times 10^{5} \\
+0.72\end{array}$ & $\begin{array}{l}2.68 \times 10^{2} \\
\pm 0.97\end{array}$ & $\begin{array}{c}1.09 \times 10^{2} \\
\pm 0.17\end{array}$ & $\begin{array}{c}9.85 \times 10^{2} \\
\pm 1.24\end{array}$ \\
\hline & & 45 & $\begin{array}{c}3.90 \times 10^{5} \\
\pm 1.27\end{array}$ & $\begin{array}{l}1.26 \times 10^{3} \\
\pm 0.15\end{array}$ & $\begin{array}{l}8.91 \times 10^{1} \\
\pm 2.97\end{array}$ & $\begin{array}{c}1.65 \times 10^{3} \\
\pm 0.07\end{array}$ \\
\hline & & 100 & $\begin{array}{c}5.23 \times 10^{4} \\
+4.61\end{array}$ & $\begin{array}{l}1.29 \times 10^{2} \\
+0.84\end{array}$ & $\begin{array}{l}1.48 \times 10^{2} \\
\pm 0.51\end{array}$ & $\begin{array}{l}2.52 \times 10^{2} \\
\pm 0.97\end{array}$ \\
\hline & & 500 & $\begin{array}{c}3.39 \times 10^{4} \\
+2.49\end{array}$ & $\begin{array}{l}3.17 \times 10^{1} \\
\pm 1.50\end{array}$ & $\begin{array}{r}5.96 \\
\pm 5.96\end{array}$ & $\begin{array}{l}1.33 \times 10^{2} \\
\pm 0.36\end{array}$ \\
\hline
\end{tabular}


Table AVI.4. Data from the R/V Oceanus (Cruise 136).

\begin{tabular}{|c|c|c|c|c|c|c|}
\hline DATE & LOCATION & $\begin{array}{l}\text { DEPTH } \\
(\mathrm{M}) \\
\end{array}$ & $\begin{array}{c}\text { HPICO } \\
(\mathrm{No} . / \mathrm{m} 1)\end{array}$ & $\begin{array}{c}\text { PPICO } \\
(\mathrm{No} . / \mathrm{m} 1) \\
\end{array}$ & $\begin{array}{l}\text { PNANO } \\
(\text { No./m } 1)\end{array}$ & $\begin{array}{c}\text { HNANO } \\
(\text { No. } / \mathrm{ml})\end{array}$ \\
\hline \multirow[t]{4}{*}{$8 / 12 / 83$} & $\begin{array}{l}41^{\circ} 22^{\prime} \mathrm{N} \\
69^{\circ} 1^{\prime} \mathrm{W}\end{array}$ & 1 & $\begin{array}{c}1.83 \times 10^{6} \\
\pm 0.13\end{array}$ & $\begin{array}{l}8.78 \times 10^{4} \\
+0.83\end{array}$ & $\begin{array}{c}1.33 \times 10^{3} \\
\pm 0.15\end{array}$ & $\begin{array}{c}1.14 \times 10^{3} \\
\pm 0.07\end{array}$ \\
\hline & & 10 & $\begin{array}{c}1.85 \times 10^{6} \\
\pm 0.09\end{array}$ & $\begin{array}{c}8.76 \times 10^{4} \\
\pm 0.08\end{array}$ & $\begin{array}{c}2.00 \times 10^{3} \\
\pm 0.27\end{array}$ & $\begin{array}{c}1.71 \times 10^{3} \\
\pm 0.12\end{array}$ \\
\hline & & 40 & $\begin{array}{l}5.93 \times 10^{5} \\
+0.39\end{array}$ & $\begin{array}{l}5.68 \times 10^{3} \\
+0.39\end{array}$ & $\begin{array}{c}5.42 \times 10^{2} \\
+0.78\end{array}$ & $\begin{array}{l}7.64 \times 10^{2} \\
\pm 1.86\end{array}$ \\
\hline & & 75 & $\begin{array}{l}4.99 \times 10^{5} \\
\pm 0.56\end{array}$ & $\begin{array}{l}1.47 \times 10^{3} \\
\pm 0.18\end{array}$ & $\begin{array}{l}1.42 \times 10^{2} \\
\pm 0.50\end{array}$ & $\begin{array}{c}9.43 \times 10^{2} \\
\pm 1.42\end{array}$ \\
\hline \multirow[t]{3}{*}{$8 / 12 / 83$} & $\begin{array}{l}41^{\circ} 00^{\prime} \mathrm{N} \\
67^{\circ} 30^{\prime} \mathrm{W}\end{array}$ & 1 & $\begin{array}{c}2.18 \times 10^{6} \\
\pm 0.18\end{array}$ & $\begin{array}{c}2.34 \times 10^{4} \\
\pm 0.44\end{array}$ & $\begin{array}{c}1.80 \times 10^{3} \\
\pm 0.14\end{array}$ & $\begin{array}{c}1.44 \times 10^{3} \\
\pm 0.08\end{array}$ \\
\hline & & 10 & $\begin{array}{l}2.21 \times 10^{6} \\
\pm 0.25\end{array}$ & $\begin{array}{l}2.63 \times 10^{4} \\
\pm 0.29\end{array}$ & $\begin{array}{l}3.00 \times 10^{3} \\
\pm 0.34\end{array}$ & $\begin{array}{c}1.58 \times 10^{3} \\
+0.18\end{array}$ \\
\hline & & 30 & $\begin{array}{c}2.15 \times 10^{6} \\
\pm 0.14\end{array}$ & $\begin{array}{c}2.98 \times 10^{4} \\
\pm 0.68\end{array}$ & $\begin{array}{c}2.48 \times 10^{3} \\
+0.25\end{array}$ & $\begin{array}{c}2.62 \times 10^{3} \\
\pm 0.14\end{array}$ \\
\hline \multirow[t]{6}{*}{$8 / 18 / 84$} & $\begin{array}{l}40^{\circ} 30^{\prime} \mathrm{N} \\
61^{\circ} 30^{\prime} \mathrm{W}\end{array}$ & 1 & $\begin{array}{c}1.10 \times 10^{6} \\
\pm 0.12\end{array}$ & $\begin{array}{c}1.20 \times 10^{4} \\
\pm 1.11\end{array}$ & $\begin{array}{l}6.68 \times 10^{2} \\
\pm 0.92\end{array}$ & $\begin{array}{l}5.93 \times 10^{2} \\
\pm 1.00\end{array}$ \\
\hline & & 20 & $\begin{array}{l}9.21 \times 10^{5} \\
\pm 0.52\end{array}$ & $\begin{array}{l}1.11 \times 10^{4} \\
\pm 0.11\end{array}$ & $\begin{array}{l}6.68 \times 10^{2} \\
\pm 1.10\end{array}$ & $\begin{array}{l}7.05 \times 10^{2} \\
+0.89\end{array}$ \\
\hline & & 50 & $\begin{array}{l}6.85 \times 10^{5} \\
\pm 0.72\end{array}$ & $\begin{array}{l}6.27 \times 10^{3} \\
\pm 0.60\end{array}$ & $\begin{array}{l}9.06 \times 10^{2} \\
\pm 1.85\end{array}$ & $\begin{array}{l}7.35 \times 10^{2} \\
+0.85\end{array}$ \\
\hline & & 100 & $\begin{array}{l}2.72 \times 10^{5} \\
\pm 0.21\end{array}$ & $\begin{array}{l}6.32 \times 10^{2} \\
\pm 2.24\end{array}$ & $\begin{array}{l}1.42 \times 10^{2} \\
\pm 0.65\end{array}$ & $\begin{array}{c}2.94 \times 10^{2} \\
\pm 0.78\end{array}$ \\
\hline & & 200 & $\begin{array}{c}1.05 \times 10^{5} \\
+0.11\end{array}$ & $\begin{array}{c}1.17 \times 10^{2} \\
\pm 0.28\end{array}$ & $\begin{array}{r}5.93 \\
+11.87\end{array}$ & $\begin{array}{c}8.01 \times 10^{1} \\
+3.92\end{array}$ \\
\hline & & 500 & $\begin{array}{c}1.19 \times 10^{5} \\
\pm 0.12\end{array}$ & $\begin{array}{r}2.25 \\
+4.39\end{array}$ & 2.97 & $\begin{array}{c}4.75 \times 10^{1} \\
+0.97\end{array}$ \\
\hline \multirow[t]{2}{*}{$8 / 20 / 83$} & $\begin{array}{l}40^{\circ} 08^{\prime} \\
56^{\circ} 51^{\prime}\end{array}$ & 1 & $\begin{array}{l}5.71 \times 10^{5} \\
\pm 0.49\end{array}$ & $\begin{array}{l}8.41 \times 10^{3} \\
+0.45\end{array}$ & $\begin{array}{c}4.33 \times 10^{2} \\
\pm 1.10\end{array}$ & $\begin{array}{c}4.64 \times 10^{2} \\
+0.74\end{array}$ \\
\hline & & 20 & $\begin{array}{l}6.65 \times 10^{5} \\
\pm 0.18\end{array}$ & $\begin{array}{l}5.61 \times 10^{3} \\
\pm 0.59\end{array}$ & $\begin{array}{l}9.96 \times 10^{2} \\
\pm 0.65\end{array}$ & $\begin{array}{c}4.64 \times 10^{2} \\
\pm 0.96\end{array}$ \\
\hline
\end{tabular}


Table AVI.4 (Continued).

\begin{tabular}{|c|c|c|c|c|c|c|}
\hline DATE & LOCATION & $\begin{array}{c}\text { DEPTH } \\
(\mathrm{M}) \\
\end{array}$ & $\begin{array}{c}\text { HPICO } \\
\text { (No./m1) }\end{array}$ & $\begin{array}{c}\text { PPICO } \\
(\mathrm{No} / \mathrm{m} 1)\end{array}$ & $\begin{array}{l}\text { PNANO } \\
(\text { No. } / \mathrm{mI})\end{array}$ & $\begin{array}{l}\text { HNANO } \\
\text { (No./m1) }\end{array}$ \\
\hline \multirow[t]{3}{*}{$\begin{array}{l}2 / 20 / 83 \\
(\text { Cont.) }\end{array}$} & $\begin{array}{l}40^{\circ} 08^{\prime} \mathrm{N} \\
56^{\circ} 51^{\prime} \mathrm{W}\end{array}$ & 50 & $\begin{array}{l}6.81 \times 10^{5} \\
\pm 0.53\end{array}$ & $\begin{array}{l}6.89 \times 10^{3} \\
\pm 0.70\end{array}$ & $\begin{array}{c}1.11 \times 10^{3} \\
\pm 0.08\end{array}$ & $\begin{array}{c}8.54 \times 10^{2} \\
\pm 1.04\end{array}$ \\
\hline & & 100 & $\begin{array}{l}7.32 \times 10^{5} \\
\pm 0.92\end{array}$ & $\begin{array}{l}4.76 \times 10^{3} \\
\pm 0.53\end{array}$ & $\begin{array}{l}8.31 \times 10^{2} \\
\pm 1.10\end{array}$ & $\begin{array}{l}5.60 \times 10^{2} \\
\pm 0.75\end{array}$ \\
\hline & & 400 & $\begin{array}{l}1.11 \times 10^{5} \\
\pm 0.08\end{array}$ & $\begin{array}{l}9.89 \times 10^{1} \\
\pm 7.18\end{array}$ & $\begin{array}{l}1.19 \times 10^{1} \\
\pm 0.97\end{array}$ & $\begin{array}{c}9.64 \times 10^{1} \\
\pm 2.88\end{array}$ \\
\hline \multirow[t]{4}{*}{$8 / 23 / 84$} & $\begin{array}{l}44^{\circ} 39^{\prime} \mathrm{N} \\
53^{\circ} 44^{\prime} \mathrm{W}\end{array}$ & 1 & $\begin{array}{c}8.41 \times 10^{5} \\
\pm 0.42\end{array}$ & $\begin{array}{l}4.46 \times 10^{4} \\
+0.37\end{array}$ & $\begin{array}{l}7.92 \times 10^{2} \\
\pm 1.12\end{array}$ & $\begin{array}{c}5.44 \times 10^{2} \\
\pm 1.28\end{array}$ \\
\hline & & 10 & $\begin{array}{l}6.58 \times 10^{5} \\
\pm 0.54\end{array}$ & $\begin{array}{l}4.10 \times 10^{4} \\
\pm 0.27\end{array}$ & $\begin{array}{l}5.69 \times 10^{2} \\
+0.64\end{array}$ & $\begin{array}{l}4.58 \times 10^{2} \\
\pm 0.59\end{array}$ \\
\hline & & 40 & $\begin{array}{c}2.36 \times 10^{6} \\
+0.18\end{array}$ & $\begin{array}{l}3.21 \times 10^{4} \\
\pm 0.21\end{array}$ & $\begin{array}{l}4.25 \times 10^{3} \\
\pm 0.39\end{array}$ & $\begin{array}{l}2.89 \times 10^{3} \\
+0.24\end{array}$ \\
\hline & & 70 & $\begin{array}{c}7.19 \times 10^{5} \\
+0.66\end{array}$ & $\begin{array}{c}4.32 \times 10^{2} \\
\pm 0.63\end{array}$ & $\begin{array}{c}2.40 \times 10^{2} \\
\pm 0.19\end{array}$ & $\begin{array}{l}3.98 \times 10^{2} \\
+0.26\end{array}$ \\
\hline
\end{tabular}


Table AVI.5. Data from the R/V Atlantis II (Cruise 109:3).

\begin{tabular}{|c|c|c|c|c|c|c|}
\hline DATE & LOCATION & $\begin{array}{l}\text { DEPTH } \\
(\mathrm{M}) \\
\end{array}$ & $\begin{array}{c}\text { HPICO } \\
(\text { No. } / \mathrm{m} 1)\end{array}$ & $\begin{array}{c}\text { PPICO } \\
(\text { No./m1) } \\
\end{array}$ & $\begin{array}{l}\text { PNANO } \\
(\text { No./m1) }\end{array}$ & $\begin{array}{l}\text { HNANO } \\
(\text { No. } / \mathrm{m} 1)\end{array}$ \\
\hline \multirow[t]{3}{*}{$8 / 14 / 81$} & $\begin{array}{l}25^{\circ} 49^{\circ} \mathrm{N} \\
19^{\circ} 54^{\prime} \mathrm{W}\end{array}$ & 1 & $2.00 \times 10^{5}$ & $\begin{array}{c}1.88 \times 10^{3} \\
\pm 0.09\end{array}$ & $\begin{array}{l}7.00 \times 10^{2} \\
\pm 0.44\end{array}$ & $\begin{array}{c}2.87 \times 10^{2} \\
\pm 0.37\end{array}$ \\
\hline & & 31 & $2.43 \times 10^{5}$ & $\begin{array}{l}1.15 \times 10^{3} \\
\pm 0.27\end{array}$ & $\begin{array}{l}2.21 \times 10^{2} \\
\pm 0.42\end{array}$ & $\begin{array}{l}1.40 \times 10^{2} \\
+0.27\end{array}$ \\
\hline & & 66 & $2.62 \times 10^{5}$ & $\begin{array}{l}6.02 \times 10^{2} \\
\pm 0.43\end{array}$ & $\begin{array}{l}7.35 \times 10^{2} \\
\pm 0.66\end{array}$ & $\begin{array}{c}2.52 \times 10^{2} \\
\pm 0.96\end{array}$ \\
\hline \multirow[t]{4}{*}{$8 / 16 / 81$} & $\begin{array}{l}24^{\circ} 30^{\prime} \mathrm{N} \\
27^{\circ} 30^{\prime} \mathrm{W}\end{array}$ & 1 & $2.70 \times 10^{5}$ & $\begin{array}{l}1.26 \times 10^{1} \\
\pm 1.45\end{array}$ & $\begin{array}{c}1.05 \times 10^{2} \\
\pm 0.73\end{array}$ & $\begin{array}{l}1.52 \times 10^{3} \\
\pm 0.78\end{array}$ \\
\hline & & 35 & $3.43 \times 10^{5}$ & $\begin{array}{r}7.56 \\
+6.93\end{array}$ & $\begin{array}{l}3.04 \times 10^{2} \\
\pm 0.64\end{array}$ & $\begin{array}{c}1.66 \times 10^{3} \\
\pm 0.21\end{array}$ \\
\hline & & 65 & $3.52 \times 10^{5}$ & $\begin{array}{l}7.81 \times 10^{2} \\
\pm 2.73\end{array}$ & $\begin{array}{l}3.15 \times 10^{2} \\
\pm 0.16\end{array}$ & $\begin{array}{l}1.61 \times 10^{3} \\
+0.14\end{array}$ \\
\hline & & 100 & $2.10 \times 10^{5}$ & $\begin{array}{l}2.76 \times 10^{3} \\
\pm 0.13\end{array}$ & $\begin{array}{l}7.93 \times 10^{2} \\
+0.87\end{array}$ & $\begin{array}{l}6.72 \times 10^{2} \\
\pm 0.36\end{array}$ \\
\hline \multirow[t]{4}{*}{$8 / 19 / 81$} & $\begin{array}{l}24^{\circ} 30^{\prime} \mathrm{N} \\
35^{\circ} 21^{\prime} \mathrm{W}\end{array}$ & 1 & $3.91 \times 10^{5}$ & 2 & $\begin{array}{c}1.46 \times 10^{2} \\
+0.64\end{array}$ & $\begin{array}{l}8.93 \times 10^{2} \\
\pm 0.55\end{array}$ \\
\hline & & 35 & $3.77 \times 10^{5}$ & $\begin{array}{c}1.47 \times 10^{1} \\
\pm 1.45\end{array}$ & $\begin{array}{l}3.15 \times 10^{2} \\
\pm 0.31\end{array}$ & $\begin{array}{c}8.45 \times 10^{2} \\
+1.32\end{array}$ \\
\hline & & 65 & $4.02 \times 10^{5}$ & $\begin{array}{l}2.31 \times 10^{2} \\
\pm 0.89\end{array}$ & $\begin{array}{l}2.21 \times 10^{2} \\
\pm 0.57\end{array}$ & $\begin{array}{c}1.1 .5 \times 10^{3} \\
\pm 0.13\end{array}$ \\
\hline & & 100 & $4.17 \times 10^{5}$ & $\begin{array}{l}1.55 \times 10^{3} \\
\pm 0.38\end{array}$ & $\begin{array}{l}5.93 \times 10^{2} \\
+0.87\end{array}$ & $\begin{array}{l}7.67 \times 10^{2} \\
+1.59\end{array}$ \\
\hline \multirow[t]{4}{*}{$8 / 22 / 81$} & $\begin{array}{l}24^{\circ} 30^{\prime} \mathrm{N} \\
41^{\circ} 53^{\prime} \mathrm{W}\end{array}$ & 1 & $4.15 \times 10^{5}$ & 2 & $\begin{array}{l}1.52 \times 10^{2} \\
\pm 0.55\end{array}$ & $\begin{array}{l}1.03 \times 10^{3} \\
\pm 0.16\end{array}$ \\
\hline & & 35 & $3.95 \times 10^{5}$ & $\begin{array}{r}2.08 \\
+3.65\end{array}$ & $\begin{array}{l}2.31 \times 10^{2} \\
+0.31\end{array}$ & $\begin{array}{l}7.82 \times 10^{2} \\
+1.59\end{array}$ \\
\hline & & 65 & $4.49 \times 10^{5}$ & $\begin{array}{l}3.15 \times 10^{2} \\
\pm 2.08\end{array}$ & $\begin{array}{l}2.89 \times 10^{2} \\
\pm 1.20\end{array}$ & $\begin{array}{l}7.87 \times 10^{2} \\
+0.98\end{array}$ \\
\hline & & 100 & $2.78 \times 10^{5}$ & $\begin{array}{l}1.70 \times 10^{3} \\
+0.24\end{array}$ & $\begin{array}{l}6.46 \times 10^{2} \\
\pm 1.40\end{array}$ & $\begin{array}{c}7.51 \times 10^{2} \\
+2.11\end{array}$ \\
\hline
\end{tabular}


Table AVI.5 (Continued).

\begin{tabular}{|c|c|c|c|c|c|c|}
\hline DATE & LOCATION & $\begin{array}{l}\text { DEPTH } \\
(\mathrm{M}) \\
\end{array}$ & $\begin{array}{c}\mathrm{HPICO} \\
(\mathrm{No} . / \mathrm{m} 1) \\
\end{array}$ & $\begin{array}{c}\text { PPICO } \\
(\mathrm{No} . / \mathrm{mI}) \\
\end{array}$ & $\begin{array}{l}\text { PNANO } \\
(\mathrm{No} . / \mathrm{m} 1) \\
\end{array}$ & $\begin{array}{l}\text { HNANO } \\
(\text { No./m1) }\end{array}$ \\
\hline \multirow[t]{4}{*}{$8 / 24 / 81$} & $\begin{array}{l}24^{\circ} 30^{\prime} \mathrm{N} \\
48^{\circ} 20^{\prime} \mathrm{W}\end{array}$ & 1 & $2.93 \times 10^{5}$ & 2 & $\begin{array}{c}1.02 \times 10^{2} \\
\pm 0.08\end{array}$ & $\begin{array}{l}9.94 \times 10^{2} \\
\pm 0.48\end{array}$ \\
\hline & & 35 & $3.52 \times 10^{5}$ & $\begin{array}{l}4.01 \times 10^{1} \\
\pm 9.20\end{array}$ & $\begin{array}{c}1.36 \times 10^{2} \\
+0.24\end{array}$ & $\begin{array}{l}1.80 \times 10^{3} \\
\pm 0.23\end{array}$ \\
\hline & & 65 & $3.90 \times 10^{5}$ & $\begin{array}{l}1.41 \times 10^{3} \\
\pm 0.74\end{array}$ & $\begin{array}{l}3.57 \times 10^{2} \\
\pm 0.60\end{array}$ & $\begin{array}{l}1.96 \times 10^{3} \\
\pm 0.19\end{array}$ \\
\hline & & 100 & $3.89 \times 10^{5}$ & $\begin{array}{c}2.36 \times 10^{3} \\
\pm 0.51\end{array}$ & $\begin{array}{c}5.04 \times 10^{2} \\
\pm 1.29\end{array}$ & $\begin{array}{l}1.33 \times 10^{3} \\
\pm 0.12\end{array}$ \\
\hline \multirow[t]{4}{*}{$8 / 26 / 81$} & $\begin{array}{l}24^{\circ} 31^{\prime} \mathrm{N} \\
55^{\circ} 07^{\prime} \mathrm{W}\end{array}$ & 1 & $3.11 \times 10^{5}$ & $\begin{array}{l}1.65 \times 10^{1} \\
\pm 6.47\end{array}$ & $\begin{array}{c}1.73 \times 10^{2} \\
\pm 0.72\end{array}$ & $\begin{array}{l}1.34 \times 10^{3} \\
\pm 0.20\end{array}$ \\
\hline & & 35 & $2.88 \times 10^{5}$ & $\begin{array}{l}3.07 \times 10^{2} \\
+3.51\end{array}$ & $\begin{array}{c}2.63 \times 10^{2} \\
\pm 0.33\end{array}$ & $\begin{array}{l}1.38 \times 10^{3} \\
\pm 0.09\end{array}$ \\
\hline & & 65 & $3.73 \times 10^{5}$ & $\begin{array}{c}1.63 \times 10^{2} \\
\pm 1.86\end{array}$ & $\begin{array}{c}2.73 \times 10^{2} \\
\pm 0.79\end{array}$ & $\begin{array}{l}1.88 \times 10^{3} \\
\pm 0.26\end{array}$ \\
\hline & & 100 & $3.26 \times 10^{5}$ & $\begin{array}{l}1.63 \times 10^{3} \\
+0.51\end{array}$ & $\begin{array}{c}6.77 \times 10^{2} \\
\pm 1.10\end{array}$ & $\begin{array}{l}1.18 \times 10^{3} \\
\pm 0.16\end{array}$ \\
\hline \multirow[t]{4}{*}{$8 / 29 / 81$} & $\begin{array}{l}24^{\circ} 30^{\prime} \mathrm{N} \\
62^{\circ} 02^{\prime} \mathrm{W}\end{array}$ & 1 & $3.07 \times 10^{5}$ & $\begin{array}{l}1.42 \times 10^{2} \\
\pm 1.65\end{array}$ & $\begin{array}{c}1.94 \times 10^{2} \\
\pm 0.40\end{array}$ & $\begin{array}{l}1.19 \times 10^{3} \\
\pm 0.14\end{array}$ \\
\hline & & 35 & $3.20 \times 10^{5}$ & $\begin{array}{l}1.34 \times 10^{3} \\
\pm 1.03\end{array}$ & $\begin{array}{c}2.57 \times 10^{2} \\
\pm 0.36\end{array}$ & $\begin{array}{l}1.17 \times 10^{3} \\
\pm 0.10\end{array}$ \\
\hline & & 65 & $4.94 \times 10^{5}$ & $\begin{array}{l}1.29 \times 10^{3} \\
\pm 0.36\end{array}$ & $\begin{array}{c}3.67 \times 10^{2} \\
\pm 0.78\end{array}$ & $\begin{array}{l}1.08 \times 10^{3} \\
\pm 0.21\end{array}$ \\
\hline & & 100 & $3.82 \times 10^{5}$ & $\begin{array}{l}2.81 \times 10^{3} \\
\pm 0.71\end{array}$ & $\begin{array}{c}8.35 \times 10^{2} \\
+2.06\end{array}$ & $\begin{array}{c}9.56 \times 10^{2} \\
\pm 1.22\end{array}$ \\
\hline \multirow[t]{3}{*}{$8 / 31 / 81$} & $\begin{array}{l}24^{\circ} 27^{\prime} \mathrm{N} \\
68^{\circ} 33^{\prime} \mathrm{W}\end{array}$ & 1 & $3.08 \times 10^{5}$ & $\begin{array}{l}1.18 \times 10^{1} \\
\pm 4.72\end{array}$ & $\begin{array}{l}3.36 \times 10^{2} \\
\pm 0.36\end{array}$ & $\begin{array}{l}9.87 \times 10^{2} \\
\pm 0.84\end{array}$ \\
\hline & & 35 & $3.26 \times 10^{5}$ & 2 & $\begin{array}{l}4.31 \times 10^{2} \\
\pm 0.96\end{array}$ & $\begin{array}{l}1.47 \times 10^{3} \\
\pm 0.07\end{array}$ \\
\hline & & 65 & $4.11 \times 10^{5}$ & $\begin{array}{r}3.94 \\
+7.87\end{array}$ & $\begin{array}{l}6.40 \times 10^{2} \\
+2.05\end{array}$ & $\begin{array}{c}1.60 \times 10^{3} \\
\pm 0.07\end{array}$ \\
\hline
\end{tabular}


Table AVI.5 (Continued).

\begin{tabular}{|c|c|c|c|c|c|c|}
\hline DATE & LOCATION & $\begin{array}{c}\text { DEPTH } \\
(M) \\
\end{array}$ & $\begin{array}{c}\text { HPICO } \\
(\text { No./m1) }\end{array}$ & $\begin{array}{c}\text { PPICO } \\
(\mathrm{No} / \mathrm{mI})\end{array}$ & $\begin{array}{l}\text { PNANO } \\
\text { (No./m1) }\end{array}$ & $\begin{array}{l}\text { HNANO } \\
(\text { No. } / \mathrm{m} 1) \\
\end{array}$ \\
\hline $\begin{array}{l}8 / 31 / 81 \\
\text { (Cont.) }\end{array}$ & $\begin{array}{l}24^{\circ} 27^{\prime} \mathrm{N} \\
68^{\circ} 33^{\prime} \mathrm{W}\end{array}$ & 100 & $3.40 \times 10^{5}$ & $\begin{array}{l}1.77 \times 10^{3} \\
\pm 0.85\end{array}$ & $\begin{array}{c}4.41 \times 10^{2} \\
+1.44\end{array}$ & $\begin{array}{l}9.34 \times 10^{2} \\
\pm 2.38\end{array}$ \\
\hline \multirow[t]{4}{*}{$9 / 3 / 81$} & $\begin{array}{l}24^{\circ} 31^{\prime} \mathrm{N} \\
75^{\circ} 01^{\prime} \mathrm{W}\end{array}$ & 1 & $5.02 \times 10^{5}$ & $\begin{array}{c}2.52 \times 10^{2} \\
\pm 0.63\end{array}$ & $\begin{array}{l}4.20 \times 10^{2} \\
\pm 0.36\end{array}$ & $\begin{array}{l}1.77 \times 10^{3} \\
\pm 0.05\end{array}$ \\
\hline & & 35 & $4.09 \times 10^{5}$ & 2 & $\begin{array}{c}2.84 \times 10^{2} \\
\pm 0.83\end{array}$ & $\begin{array}{c}1.49 \times 10^{3} \\
\pm 0.14\end{array}$ \\
\hline & & 65 & $5.74 \times 10^{5}$ & $\begin{array}{c}1.10 \times 10^{3} \\
\pm 0.18\end{array}$ & $\begin{array}{l}1.25 \times 10^{3} \\
\pm 0.32\end{array}$ & $\begin{array}{l}1.35 \times 10^{3} \\
\pm 0.11\end{array}$ \\
\hline & & 100 & $6.03 \times 10^{5}$ & $\begin{array}{l}3.22 \times 10^{3} \\
+0.69\end{array}$ & $\begin{array}{l}5.57 \times 10^{2} \\
\pm 0.96\end{array}$ & $\begin{array}{l}4.31 \times 10^{2} \\
\pm 0.66\end{array}$ \\
\hline \multirow[t]{4}{*}{$9 / 5 / 81$} & $\begin{array}{l}26^{\circ} 04^{\prime} \mathrm{N} \\
79^{\circ} 23^{\prime} \mathrm{W}\end{array}$ & 1 & $6.43 \times 10^{5}$ & $\begin{array}{c}3.46 \times 10^{1} \\
\pm 3.59\end{array}$ & $\begin{array}{l}2.84 \times 10^{2} \\
\pm 0.54\end{array}$ & $\begin{array}{l}1.51 \times 10^{3} \\
\pm 0.05\end{array}$ \\
\hline & & 35 & $4.55 \times 10^{5}$ & $\begin{array}{l}2.72 \times 10^{2} \\
\pm 2.08\end{array}$ & $\begin{array}{l}6.40 \times 10^{2} \\
+0.79\end{array}$ & $\begin{array}{l}1.63 \times 10^{3} \\
\pm 0.07\end{array}$ \\
\hline & & 65 & $4.75 \times 10^{5}$ & $\begin{array}{l}2.19 \times 10^{4} \\
\pm 0.14\end{array}$ & $\begin{array}{c}6.62 \times 10^{2} \\
\pm 1.14\end{array}$ & $\begin{array}{l}6.83 \times 10^{2} \\
+0.48\end{array}$ \\
\hline & & 100 & $2.55 \times 10^{5}$ & $\begin{array}{l}2.62 \times 10^{2} \\
\pm 0.45\end{array}$ & $\begin{array}{c}6.93 \times 10^{2} \\
\pm 1.37\end{array}$ & $\begin{array}{c}3.36 \times 10^{2} \\
\pm 1.27\end{array}$ \\
\hline
\end{tabular}


Table AVI.6. Data from Lake Ontario on $4 / 28$ and $4 / 29 / 82$.

\begin{tabular}{|c|c|c|c|c|c|c|}
\hline DATE & LOCATION & $\begin{array}{l}\text { DEPTH } \\
\text { (M) } \\
\end{array}$ & $\begin{array}{l}\text { HPICO } \\
(\text { No./m1) } \\
\end{array}$ & $\begin{array}{l}\text { PPICO } \\
(\mathrm{No} . / \mathrm{m} 1)\end{array}$ & $\begin{array}{l}\text { PNANO } \\
(\text { No./m1) } \\
\end{array}$ & $\begin{array}{l}\text { HNANO } \\
(\text { No./m1) }\end{array}$ \\
\hline \multirow[t]{5}{*}{$4 / 29 / 82$} & Sta. 401 & 1 & $\begin{array}{l}1.75 \times 10^{6} \\
+0.23\end{array}$ & $\begin{array}{l}3.67 \times 10^{2} \\
\pm 2.49\end{array}$ & $\begin{array}{l}4.28 \times 10^{3} \\
\pm 0.11\end{array}$ & $\begin{array}{l}1.89 \times 10^{3} \\
\pm 0.74\end{array}$ \\
\hline & & 5 & $\begin{array}{c}1.66 \times 10^{6} \\
\pm 0.61\end{array}$ & $\begin{array}{l}4.25 \times 10^{2} \\
\pm 3.54\end{array}$ & $\begin{array}{l}4.48 \times 10^{3} \\
\pm 0.43\end{array}$ & $\begin{array}{l}7.62 \times 10^{2} \\
\pm 1.81\end{array}$ \\
\hline & & 15 & $\begin{array}{l}2.42 \times 10^{6} \\
\pm 0.40\end{array}$ & $2.97 \times 10^{1}$ & $\begin{array}{c}4.35 \times 10^{3} \\
\pm 0.27\end{array}$ & $\begin{array}{l}9.70 \times 10^{2} \\
\pm 2.56\end{array}$ \\
\hline & v & 24 & $\begin{array}{l}1.64 \times 10^{6} \\
\pm 0.33\end{array}$ & $\begin{array}{l}5.44 \times 10^{2} \\
\pm 3.12\end{array}$ & $\begin{array}{l}4.41 \times 10^{3} \\
\pm 0.59\end{array}$ & $\begin{array}{l}8.91 \times 10^{2} \\
\pm 1.85\end{array}$ \\
\hline & & 32 & $\begin{array}{l}2.54 \times 10^{6} \\
\pm 0.45\end{array}$ & $\begin{array}{c}3.96 \times 10^{2} \\
\pm 1.13\end{array}$ & $\begin{array}{l}4.75 \times 10^{3} \\
\pm 0.39\end{array}$ & $\begin{array}{l}8.91 \times 10^{2} \\
\pm 0.79\end{array}$ \\
\hline \multirow[t]{11}{*}{$4 / 28 / 82$} & Sta. 403 & 1 & $\begin{array}{l}1.62 \times 10^{6} \\
\pm 0.21\end{array}$ & $\begin{array}{l}3.46 \times 10^{2} \\
\pm 1.74\end{array}$ & $\begin{array}{l}2.56 \times 10^{3} \\
\pm 0.10\end{array}$ & $\begin{array}{l}7.62 \times 10^{2} \\
\pm 0.69\end{array}$ \\
\hline & & 5 & $\begin{array}{l}1.37 \times 10^{6} \\
\pm 0.35\end{array}$ & $\begin{array}{l}4.96 \times 10^{1} \\
+8.58\end{array}$ & $\begin{array}{l}2.66 \times 10^{3} \\
\pm 0.10\end{array}$ & $\begin{array}{l}9.41 \times 10^{2} \\
+0.45\end{array}$ \\
\hline & & 15 & $\begin{array}{c}1.57 \times 10^{6} \\
\pm 0.36\end{array}$ & $2.97 \times 10^{1}$ & $\begin{array}{l}3.10 \times 10^{3} \\
\pm 0.16\end{array}$ & $\begin{array}{l}8.61 \times 10^{2} \\
+0.89\end{array}$ \\
\hline & & 25 & $\begin{array}{l}1.67 \times 10^{6} \\
\pm 0.22\end{array}$ & $\begin{array}{l}1.39 \times 10^{2} \\
\pm 1.91\end{array}$ & $\begin{array}{l}2.81 \times 10^{3} \\
\pm 0.13\end{array}$ & $\begin{array}{l}1.86 \times 10^{3} \\
+0.43\end{array}$ \\
\hline & & 50 & $\begin{array}{l}1.58 \times 10^{6} \\
\pm 0.74\end{array}$ & $\begin{array}{l}2.38 \times 10^{2} \\
+2.38\end{array}$ & $\begin{array}{l}2.63 \times 10^{3} \\
\pm 0.15\end{array}$ & $\begin{array}{l}1.38 \times 10^{3} \\
\pm 0.03\end{array}$ \\
\hline & & 75 & $\begin{array}{c}2.00 \times 10^{6} \\
\pm 0.39\end{array}$ & $2.97 \times 10^{1}$ & $\begin{array}{l}2.72 \times 10^{3} \\
\pm 0.21\end{array}$ & $\begin{array}{l}1.89 \times 10^{3} \\
\pm 0.56\end{array}$ \\
\hline & & 100 & $\begin{array}{l}1.90 \times 10^{6} \\
\pm 0.25\end{array}$ & $\begin{array}{l}1.98 \times 10^{2} \\
+2.47\end{array}$ & $\begin{array}{l}2.78 \times 10^{3} \\
\pm 0.33\end{array}$ & $\begin{array}{l}1.12 \times 10^{3} \\
\pm 0.07\end{array}$ \\
\hline & & 125 & $\begin{array}{c}1.98 \times 10^{6} \\
+0.36\end{array}$ & $\begin{array}{l}3.66 \times 10^{2} \\
+3.26\end{array}$ & $\begin{array}{l}2.86 \times 10^{3} \\
+0.30\end{array}$ & $\begin{array}{l}5.84 \times 10^{2} \\
\pm 1.49\end{array}$ \\
\hline & & 150 & $\begin{array}{l}2.08 \times 10^{6} \\
\pm 0.49\end{array}$ & $\begin{array}{c}2.87 \times 10^{2} \\
\pm 1.64\end{array}$ & $\begin{array}{l}3.08 \times 10^{3} \\
\pm 0.28\end{array}$ & $\begin{array}{c}6.83 \times 10^{2} \\
\pm 0.51\end{array}$ \\
\hline & & 165 & $\begin{array}{c}1.97 \times 10^{6} \\
+0.47\end{array}$ & $\begin{array}{l}4.45 \times 10^{2} \\
+0.89\end{array}$ & $\begin{array}{l}2.88 \times 10^{3} \\
\pm 0.18\end{array}$ & $\begin{array}{c}6.23 \times 10^{2} \\
\pm 1.57\end{array}$ \\
\hline & & 173 & $\begin{array}{l}1.83 \times 10^{6} \\
\pm 0.22\end{array}$ & $\begin{array}{l}3.96 \times 10^{2} \\
\pm 1.98\end{array}$ & $\begin{array}{l}2.83 \times 10^{3} \\
\pm 0.28\end{array}$ & $\begin{array}{l}8.02 \times 10^{2} \\
\pm 1.19\end{array}$ \\
\hline
\end{tabular}


Table AVI.7. Data from Lake Ontario on $6 / 28$ and $6 / 29 / 82$.

\begin{tabular}{|c|c|c|c|c|c|c|}
\hline DATE & LOCATION & $\begin{array}{l}\text { DEPTH } \\
(\mathrm{M}) \\
\end{array}$ & $\begin{array}{c}\text { HPICO } \\
\text { (No./m1) }\end{array}$ & $\begin{array}{c}\text { PPICO } \\
\text { (No./m } 1)\end{array}$ & $\begin{array}{l}\text { PNANO } \\
(\text { No./ml) }\end{array}$ & $\begin{array}{l}\text { HNANO } \\
(\text { No./m1) }\end{array}$ \\
\hline \multirow[t]{6}{*}{$6 / 28 / 82$} & Sta. 401 & 1 & $\begin{array}{l}3.55 \times 10^{6} \\
+0.61\end{array}$ & $\begin{array}{c}2.15 \times 10^{4} \\
\pm 0.48\end{array}$ & $\begin{array}{l}3.00 \times 10^{3} \\
\pm 0.24\end{array}$ & $\begin{array}{c}4.36 \times 10^{3} \\
\pm 0.32\end{array}$ \\
\hline & & 5 & $\begin{array}{l}3.76 \times 10^{6} \\
\pm 0.85\end{array}$ & $\begin{array}{c}1.23 \times 10^{4} \\
\pm 0.26\end{array}$ & $\begin{array}{c}1.70 \times 10^{3} \\
\pm 0.12\end{array}$ & $\begin{array}{l}4.31 \times 10^{3} \\
\pm 0.33\end{array}$ \\
\hline & & 10 & $\begin{array}{c}3.70 \times 10^{6} \\
+0.41\end{array}$ & $\begin{array}{c}1.02 \times 10^{4} \\
\pm 0.05\end{array}$ & $\begin{array}{l}3.02 \times 10^{3} \\
\pm 0.56\end{array}$ & $\begin{array}{l}3.65 \times 10^{3} \\
\pm 0.33\end{array}$ \\
\hline & & 15 & $\begin{array}{l}4.09 \times 10^{6} \\
\pm 0.35\end{array}$ & $\begin{array}{l}3.16 \times 10^{3} \\
\pm 0.77\end{array}$ & $\begin{array}{l}9.60 \times 10^{2} \\
\pm 2.19\end{array}$ & $\begin{array}{l}3.50 \times 10^{3} \\
\pm 0.47\end{array}$ \\
\hline & & 28 & $\begin{array}{c}3.52 \times 10^{6} \\
\pm 0.53\end{array}$ & $\begin{array}{l}3.05 \times 10^{3} \\
\pm 0.20\end{array}$ & $\begin{array}{l}9.80 \times 10^{2} \\
\pm 1.57\end{array}$ & $\begin{array}{l}2.28 \times 10^{3} \\
+0.43\end{array}$ \\
\hline & & 36 & $\begin{array}{l}3.10 \times 10^{6} \\
\pm 0.48\end{array}$ & $\begin{array}{l}2.68 \times 10^{3} \\
\pm 0.51\end{array}$ & $\begin{array}{c}1.11 \times 10^{3} \\
\pm 0.43\end{array}$ & $\begin{array}{l}2.15 \times 10^{3} \\
\pm 0.25\end{array}$ \\
\hline \multirow[t]{9}{*}{$6 / 29 / 82$} & Sta. 403 & 1 & $\begin{array}{l}2.01 \times 10^{6} \\
\pm 0.32\end{array}$ & $\begin{array}{c}4.45 \times 10^{2} \\
\pm 1.29\end{array}$ & $\begin{array}{c}4.40 \times 10^{3} \\
\pm 1.41\end{array}$ & $\begin{array}{l}4.63 \times 10^{3} \\
\pm 1.23\end{array}$ \\
\hline & & 5 & $\begin{array}{c}1.66 \times 10^{6} \\
\pm 0.17\end{array}$ & $\begin{array}{l}4.65 \times 10^{2} \\
\pm 2.23\end{array}$ & $\begin{array}{l}5.27 \times 10^{3} \\
\pm 0.30\end{array}$ & $\begin{array}{l}1.78 \times 10^{3} \\
+0.58\end{array}$ \\
\hline & & 10 & $\begin{array}{c}1.74 \times 10^{6} \\
\pm 0.20\end{array}$ & $\begin{array}{c}3.96 \times 10^{2} \\
+3.73\end{array}$ & $\begin{array}{l}5.43 \times 10^{3} \\
+0.98\end{array}$ & $\begin{array}{c}2.64 \times 10^{3} \\
\pm 0.73\end{array}$ \\
\hline & & 15 & $\begin{array}{c}2.40 \times 10^{6} \\
\pm 0.20\end{array}$ & $\begin{array}{c}5.34 \times 10^{2} \\
+3.37\end{array}$ & $\begin{array}{l}4.20 \times 10^{3} \\
\pm 0.52\end{array}$ & $\begin{array}{l}3.30 \times 10^{3} \\
\pm 0.82\end{array}$ \\
\hline & & 25 & $\begin{array}{c}1.97 \times 10^{6} \\
+0.15\end{array}$ & $\begin{array}{l}7.32 \times 10^{2} \\
\pm 1.04\end{array}$ & $\begin{array}{l}3.75 \times 10^{3} \\
+0.29\end{array}$ & $\begin{array}{c}2.77 \times 10^{3} \\
+0.54\end{array}$ \\
\hline & & 50 & $\begin{array}{c}1.69 \times 10^{6} \\
+0.16\end{array}$ & $\begin{array}{l}6.53 \times 10^{2} \\
+2.64\end{array}$ & $\begin{array}{l}3.93 \times 10^{3} \\
+0.28\end{array}$ & $\begin{array}{l}2.48 \times 10^{3} \\
\pm 0.34\end{array}$ \\
\hline & & 75 & $\begin{array}{c}1.76 \times 10^{6} \\
+0.18\end{array}$ & $\begin{array}{c}6.83 \times 10^{2} \\
\pm 2.37\end{array}$ & $\begin{array}{l}3.55 \times 10^{3} \\
\pm 0.27\end{array}$ & $\begin{array}{c}1.61 \times 10^{3} \\
+0.16\end{array}$ \\
\hline & & 100 & $\begin{array}{l}1.66 \times 10^{6} \\
\pm 0.12\end{array}$ & $\begin{array}{c}4.95 \times 10^{2} \\
+2.27\end{array}$ & $\begin{array}{l}3.18 \times 10^{3} \\
\pm 0.21\end{array}$ & $\begin{array}{l}2.01 \times 10^{3} \\
+0.56\end{array}$ \\
\hline & & 125 & $\begin{array}{c}1.94 \times 10^{6} \\
+0.18\end{array}$ & $\begin{array}{c}2.04 \times 10^{2} \\
\pm 1.39\end{array}$ & $\begin{array}{l}2.94 \times 10^{3} \\
+0.33\end{array}$ & $\begin{array}{l}2.12 \times 10^{3} \\
+0.58\end{array}$ \\
\hline
\end{tabular}


Table AVI. 7 (Continued).

\begin{tabular}{|c|c|c|c|c|c|c|}
\hline DATE & LOCATION & $\begin{array}{l}\text { DEPTH } \\
(\mathrm{M}) \\
\end{array}$ & $\begin{array}{c}\text { HPICO } \\
\text { (No./m1) }\end{array}$ & $\begin{array}{c}\text { PPICO } \\
(\mathrm{No} \cdot / \mathrm{m} \mathrm{I})\end{array}$ & $\begin{array}{l}\text { PNANO } \\
(\text { No.//m } 1)\end{array}$ & $\begin{array}{l}\text { HNANO } \\
(\text { No./m } 1)\end{array}$ \\
\hline \multirow[t]{3}{*}{$6 / 29 / 82$} & $\begin{array}{l}\text { Sta. } 403 \\
\text { (Cont.) }\end{array}$ & 150 & $\begin{array}{l}1.76 \times 10^{6} \\
\pm 0.16\end{array}$ & $\begin{array}{l}3.63 \times 10^{2} \\
+1.21\end{array}$ & $\begin{array}{l}2.08 \times 10^{3} \\
\pm 0.08\end{array}$ & $\begin{array}{l}3.58 \times 10^{3} \\
\pm 0.87\end{array}$ \\
\hline & & 165 & $\begin{array}{c}1.81 \times 10^{6} \\
\pm 0.18\end{array}$ & $\begin{array}{c}4.61 \times 10^{1} \\
+4.98\end{array}$ & $\begin{array}{l}1.58 \times 10^{3} \\
+0.29\end{array}$ & $\begin{array}{c}3.60 \times 10^{3} \\
\pm 0.45\end{array}$ \\
\hline & & 173 & $\begin{array}{c}1.75 \times 10^{6} \\
\pm 0.19\end{array}$ & $\begin{array}{c}2.04 \times 10^{2} \\
\pm 0.89\end{array}$ & $\begin{array}{c}1.44 \times 10^{3} \\
\pm 0.04\end{array}$ & $\begin{array}{l}3.07 \times 10^{3} \\
+0.14\end{array}$ \\
\hline
\end{tabular}


Table III-8. Data from Lake Ontario on $8 / 23$ and $8 / 24 / 82$.

\begin{tabular}{|c|c|c|c|c|c|c|}
\hline DATE & LOCATION & $\begin{array}{l}\text { DEPTH } \\
(\mathrm{M}) \\
\end{array}$ & $\begin{array}{c}\text { HPICO } \\
(\text { No./m1) } \\
\end{array}$ & $\begin{array}{c}\text { PPICO } \\
(\mathrm{No} . / \mathrm{m} 1)\end{array}$ & $\begin{array}{l}\text { PNANO } \\
(\text { No./m1) }\end{array}$ & $\begin{array}{l}\text { HNANO } \\
\text { (No./m1) }\end{array}$ \\
\hline \multirow[t]{6}{*}{$8 / 23 / 82$} & Sta. 401 & 1 & $\begin{array}{c}6.13 \times 10^{6} \\
\pm 0.38\end{array}$ & $\begin{array}{l}5.02 \times 10^{5} \\
\pm 0.98\end{array}$ & $\begin{array}{l}3.54 \times 10^{3} \\
\pm 0.23\end{array}$ & $\begin{array}{c}8.91 \times 10^{2} \\
\pm 2.23\end{array}$ \\
\hline & & 5 & $\begin{array}{l}4.71 \times 10^{6} \\
\pm 0.47\end{array}$ & $\begin{array}{c}6.54 \times 10^{5} \\
\pm 0.87\end{array}$ & $\begin{array}{l}3.09 \times 10^{3} \\
\pm 0.53\end{array}$ & $\begin{array}{c}1.54 \times 10^{3} \\
\pm 0.37\end{array}$ \\
\hline & & 10 & $\begin{array}{c}2.85 \times 10^{6} \\
+0.28\end{array}$ & $\begin{array}{c}1.97 \times 10^{5} \\
\pm 0.33\end{array}$ & $\begin{array}{c}1.95 \times 10^{3} \\
\pm 0.46\end{array}$ & $\begin{array}{c}9.40 \times 10^{2} \\
\pm 1.04\end{array}$ \\
\hline & & 15 & $\begin{array}{l}1.72 \times 10^{6} \\
\pm 0.31\end{array}$ & $\begin{array}{c}3.65 \times 10^{4} \\
\pm 1.28\end{array}$ & $\begin{array}{l}1.42 \times 10^{3} \\
\pm 0.27\end{array}$ & $\begin{array}{l}7.82 \times 10^{2} \\
\pm 0.62\end{array}$ \\
\hline & & 27 & $\begin{array}{c}1.46 \times 10^{6} \\
\pm 0.21\end{array}$ & $\begin{array}{l}3.67 \times 10^{4} \\
\pm 0.91\end{array}$ & $\begin{array}{c}2.24 \times 10^{3} \\
\pm 0.13\end{array}$ & $\begin{array}{c}1.23 \times 10^{3} \\
\pm 0.28\end{array}$ \\
\hline & & 35 & $\begin{array}{l}1.54 \times 10^{6} \\
\pm 0.15\end{array}$ & $\begin{array}{c}2.75 \times 10^{4} \\
\pm 1.64\end{array}$ & $\begin{array}{c}2.30 \times 10^{3} \\
\pm 0.42\end{array}$ & $\begin{array}{c}1.43 \times 10^{3} \\
+0.13\end{array}$ \\
\hline \multirow[t]{9}{*}{$8 / 24 / 82$} & Sta. 403 & 1 & $\begin{array}{c}5.17 \times 10^{6} \\
\pm 0.29\end{array}$ & $\begin{array}{l}3.52 \times 10^{5} \\
\pm 1.32\end{array}$ & $\begin{array}{c}3.29 \times 10^{3} \\
+0.23\end{array}$ & $\begin{array}{c}1.58 \times 10^{3} \\
\pm 0.35\end{array}$ \\
\hline & & 5 & $\begin{array}{l}4.67 \times 10^{6} \\
\pm 0.82\end{array}$ & $\begin{array}{l}4.29 \times 10^{5} \\
\pm 0.56\end{array}$ & $\begin{array}{l}4.16 \times 10^{3} \\
\pm 0.39\end{array}$ & $\begin{array}{l}1.24 \times 10^{3} \\
\pm 0.24\end{array}$ \\
\hline & & 10 & $\begin{array}{l}3.73 \times 10^{6} \\
\pm 1.39\end{array}$ & $\begin{array}{l}4.59 \times 10^{5} \\
\pm 1.20\end{array}$ & $\begin{array}{l}5.86 \times 10^{3} \\
+0.39\end{array}$ & $\begin{array}{l}2.18 \times 10^{3} \\
+0.52\end{array}$ \\
\hline & & 15 & $\begin{array}{l}3.98 \times 10^{6} \\
+0.33\end{array}$ & $\begin{array}{c}4.76 \times 10^{5} \\
+1.07\end{array}$ & $\begin{array}{l}4.13 \times 10^{3} \\
+0.37\end{array}$ & $\begin{array}{l}1.09 \times 10^{3} \\
\pm 0.24\end{array}$ \\
\hline & & 25 & $\begin{array}{c}1.14 \times 10^{6} \\
\pm 0.14\end{array}$ & $\begin{array}{l}9.14 \times 10^{4} \\
\pm 0.56\end{array}$ & $\begin{array}{l}4.03 \times 10^{3} \\
\pm 0.43\end{array}$ & $\begin{array}{l}2.55 \times 10^{3} \\
+0.26\end{array}$ \\
\hline & & 50 & $\begin{array}{l}9.14 \times 10^{5} \\
\pm 1.78\end{array}$ & $\begin{array}{c}1.17 \times 10^{4} \\
\pm 0.18\end{array}$ & $\begin{array}{l}2.42 \times 10^{3} \\
\pm 0.26\end{array}$ & $\begin{array}{l}7.42 \times 10^{2} \\
\pm 2.68\end{array}$ \\
\hline & & 75 & $\begin{array}{l}9.51 \times 10^{5} \\
\pm 1.95\end{array}$ & $\begin{array}{l}2.78 \times 10^{3} \\
+0.29\end{array}$ & $\begin{array}{l}3.57 \times 10^{3} \\
+0.17\end{array}$ & $\begin{array}{l}4.25 \times 10^{2} \\
+0.69\end{array}$ \\
\hline & & 100 & $\begin{array}{l}7.52 \times 10^{5} \\
\pm 2.23\end{array}$ & $\begin{array}{l}7.75 \times 10^{3} \\
\pm 0.56\end{array}$ & $\begin{array}{l}3.94 \times 10^{3} \\
+0.14\end{array}$ & $\begin{array}{c}4.65 \times 10^{2} \\
\pm 0.17\end{array}$ \\
\hline & & 125 & $\begin{array}{c}9.50 \times 10^{5} \\
+2.28\end{array}$ & $\begin{array}{l}2.14 \times 10^{3} \\
\pm 0.08\end{array}$ & $\begin{array}{c}1.41 \times 10^{3} \\
\pm 0.41\end{array}$ & $\begin{array}{c}3.36 \times 10^{2} \\
+1.34\end{array}$ \\
\hline
\end{tabular}


Table AVI.8 (Continued).

\begin{tabular}{|c|c|c|c|c|c|c|}
\hline DATE & LOCATION & $\begin{array}{l}\text { DEPTH } \\
(\mathrm{M}) \\
\end{array}$ & $\begin{array}{c}\text { HPICO } \\
\text { (No./m1) } \\
\end{array}$ & $\begin{array}{c}\text { PPICO } \\
\text { (No./m1) }\end{array}$ & $\begin{array}{l}\text { PNANO } \\
(\text { No. } / \mathrm{m} 1)\end{array}$ & $\begin{array}{l}\text { HNANO } \\
(\mathrm{No} / \mathrm{m} 1)\end{array}$ \\
\hline \multirow[t]{3}{*}{$8 / 24 / 82$} & $\begin{array}{l}\text { Sta. } 403 \\
\text { (Cont.) }\end{array}$ & 150 & $\begin{array}{c}1.05 \times 10^{6} \\
\pm 0.18\end{array}$ & $\begin{array}{c}1.16 \times 10^{3} \\
\pm 0.54\end{array}$ & $\begin{array}{l}3.76 \times 10^{3} \\
+0.29\end{array}$ & $\begin{array}{c}3.56 \times 10^{2} \\
\pm 0.51\end{array}$ \\
\hline & & 166 & $\begin{array}{l}8.37 \times 10^{5} \\
\pm 1.96\end{array}$ & $\begin{array}{l}3.15 \times 10^{3} \\
\pm 0.54\end{array}$ & $\begin{array}{l}4.47 \times 10^{3} \\
\pm 0.15\end{array}$ & $\begin{array}{l}1.14 \times 10^{3} \\
\pm 0.16\end{array}$ \\
\hline & & 174 & $\begin{array}{c}1.51 \times 10^{6} \\
\pm 0.24\end{array}$ & $\begin{array}{l}1.08 \times 10^{3} \\
\pm 0.51\end{array}$ & $\begin{array}{c}2.64 \times 10^{3} \\
\pm 0.19\end{array}$ & $\begin{array}{c}3.36 \times 10^{2} \\
\pm 1.33\end{array}$ \\
\hline
\end{tabular}


THESIS SUMMARY

A role for heterotrophic microflagellates in plankton communities as a trophic link between bacterla and filter-feeding zooplankton has been confirmed by this study. The distribution study (Chapter 1) established that heterotrophic microflagellates are a ubiquitous and abundant component of plankton communities with densities ranging from hundreds to thousands $\mathrm{ml}^{-1}$ in surface waters. These protozoa constituted a significant fraction of the biomass of pico- and nanoplankton in the North Atlantic and in Lake Ontario throughout the year.

Macroscopic detrital aggregates and other planktonic microenvironments in the North Atlantic were characterlzed by highly elevated concentrations of heterotrophic microflagellates (Chapter 2). The growth characteristics of some cultured microflagellates (Chapter 4) suggest that they are capable of feeding on bacterla attached to particles in the plankton. In turn, the distribution of these surface-assoclated microflagellates may be closely Iinked to the distribution of particles in the pelagic environment and their attached bacteria.

Species of microflagellates were also cultured which were capable of feeding on relatively low concentrations of unattached, free-living bacteria. Batch and continuous culture of such species (Chapter 3) showed that some species are capable of reducing bacterial concentrations to densities normally observed in planktonic communities. If feeding thresholds exist for these protozoa, they are below the densities of bacterfa normally observed in the plankton. This ability implies that bacterivorous microflagellates may be the major factor controlling the density of bacteria in the plankton. Conversion efficiencies of microflagellates were relatively high even when microflagellates were grown at relatively slow growth rates. Therefore, much 
of the energy and organic carbon contained in bacterioplankton may be retained as microflagellate blomass and thereby made available to filter-feeding zooplankton.

Survival and selective feeding experiments with the copepod Acartia tonsa confirmed the potential for the utilization of microflagellate biomass by filter-feeding zooplankton. Microflagellates were consumed at rates comparable to rates for similarly-sized phytoplankton and resulted in copepod survival rates equivalent to survival rates of copepods fed phytoplankton. A pathway was therefore established by which energy contained in the detrital food chain could be returned to the classical phytoplankton-copepod-fish food chain. 